\title{
A cidade e a mobilidade na era do automóvel a obra de Colin Buchanan (1958-1966)
}

Alexandre Rodrigues Seixas

Tese de doutorado apresentada ao Programa de Pós-Graduação em Arquitetura e Urbanismo da Escola de Engenharia de São Carlos da Universidade de São Paulo, como parte dos requisitos para obtenção do título de Doutor em Teoria e História da Arquitetura e do Urbanismo 

Candidato: Arquiteto e Urbanista ALEXANDRE RODRIGUES SEIXAS.

Tese defendida e juggada em 26/08/2010 perante a Comissão Julgadora:

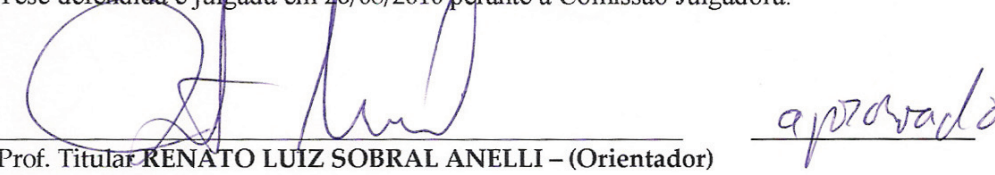

Escola de Engenharia de São Carlos/USP)

gnNen

ARROUANO

Prof?. Associada SARAH FELDMAN

(Escola de Engenharia de São Carlos/USP)

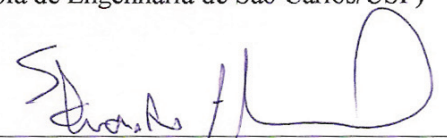

Dr. EDUARDO ALCÂNTARA DE VASCONCELOS

(Associação Nacional de Transportes Públicos/ANTP)

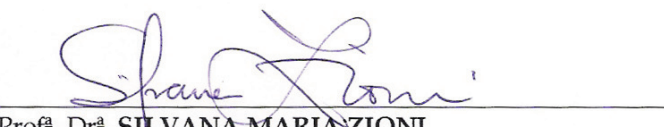

(Universidade Federal do ABC/UFABC)

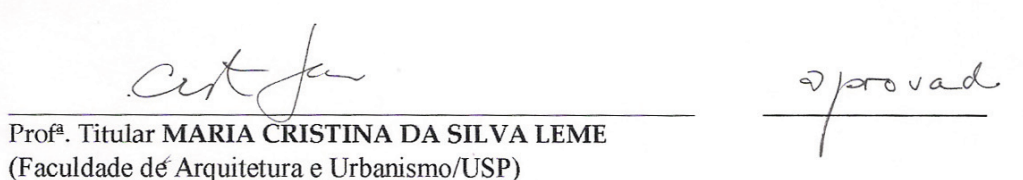

Faculdade de Arquitetura e Urbanismo/USP)

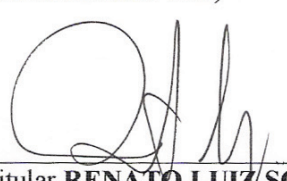

Prof Titular RENATO LUId SOBRAL ANELLI

Coordenador do Programa de Pós-Graduação em

Arquitetura e Urbanismo

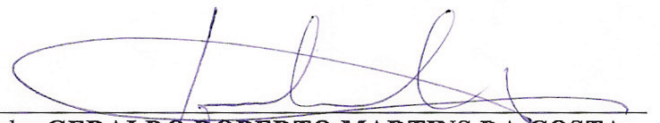

Prof. Titular GERALDO ROBERTO MARTINS DA COSTA

Presidente da Comissão da Pós-Graduação da EESC 



\section{A cidade e a mobilidade na era do automóvel}

a obra de Colin Buchanan (1958-1966) 
AUTORIZO A REPRODUCÃO E DIVULGACCÃO TOTAL OU PARCIAL DESTE

TRABALHO, POR QUALQUER MEIO CONVENCIONAL OU ELETRÔNICO,

PARA FINS DE ESTUDO E PESQUISA, DESDE QUE CITADA A FONTE.

Ficha catalográfica preparada pela Seção de Tratamento da Informação do Serviço de Biblioteca - EESC/USP

S462c Seixas, Alexandre Rodrigues
A cidade e a mobilidade na era do automóvel: a obra
de Colin Buchanan (1958-1966)/ / Alexandre Rodrigues
Seixas, orientador Renato Luiz Sobral Anelli. -- São
Carlos, 2010.
Tese (Doutorado-Programa de Pós-Graduação em
Arquitetura e Urbanismo e Área de Concentraça em
Teoria e História da Arquitetura e Urbanismo) --
Escola de Engenharia de São Carlos da Universidade de
São Paulo, 2010.
1. Colin Buchanan. 2. Mobilidade urbana.
3. Planejamento de transportes. 4. Planejamento
urbano. I. Título.




\section{A cidade e a mobilidade na era do automóvel a obra de Colin Buchanan (1958-1966)}

\section{Alexandre Rodrigues Seixas}

Tese de doutorado apresentada ao Programa de Pós-Graduação em Arquitetura e Urbanismo da Escola de Engenharia de São Carlos da Universidade de São Paulo, como parte dos requisitos para obtenção do título de Doutor em Teoria e História da Arquitetura e do Urbanismo

Orientador: Prof. Titular Renato Luiz Sobral Anelli 

Para Cibele. 



\section{agradecimentos}

Ao Prof. Renato Anelli, orientador desta tese: por quase dez anos de trabalho em conjunto; por muitos assuntos discutidos, por artigos, pela parceria e principalmente pela paciência e amizade.

Ao professor Antony Lloyd Jones que me acolheu na Universidade de Westminster em Londres e me abriu uma oportunidade que nunca havia pensado.

A Malcolm Buchanan por sua extrema receptividade, simplicidade e gentileza.

A Eduardo Vasconcellos por seus escritos pioneiros no Brasil e pela conversa acolhedora sobre mobilidade urbana em um momento estratégico desta tese.

Às professoras Sarah Feldmann e Maria Cristina Leme pelas contribuições na banca de qualificação.

A Marta Bogea e Luiz Augusto Contier como representantes de todos os meus colegas e alunos da Universidade São Judas Tadeu, mas particularmente pela confiança que ambos têm depositado em meu trabalho.

A Arlindo Fernandes, Adolfo de Mendonça, Marcos Bicalho, Antonio Luiz Santana, Felício Sakamoto, Roberto Mac Fadden e Dominique Mouette que, ao longo de quase dez anos, têm sido meus professores da relação entre transportes e cidade. Em especial, a Fábio Quintela Fortes (in memorian).

Ao Prof. Carlos Roberto Monteiro de Andrade, pela companhia e aula particular na visita a Letchworth Garden City, e ao Prof. Fernando de Melo Franco, pela interlocução rara, mas estimulante.

Aos amigos e parceiros de trabalho Roberto Zocchio, Gustavo Partezani, Ana Paula Khoury, Sandra Ichikawa, Daniel Robles.

Aos meus amigos Eduardo Kawakami, Marcos Renato Pinheiro e Carlos Alberto Yamada. Também a Jane de Siqueira.

À Mariana Cotrim pela diagramação deste trabalho e pelo esforço para tornar as imagens legíveis.

A FAPESP pela bolsa concedida durante parte deste trabalho e, particularmente, por viabilizar o estágio de pesquisa no exterior.

A minha família pela compreensão nas ausências que este trabalho demandou.

A Cibele Franzese, por tanta coisa que seria injusto tentar resumir. Fizemos nossas teses de doutorado ao mesmo tempo e saímos quase ilesos desta insanidade estratégica. Seguramente esta tese seria muito pior sem ela e talvez nem existisse. 



\section{sumário}

índice de imagens 13

resumo 21

abstract 23

introdução 25

A nova escala do problema do tráfego urbano em meados do século XX 25 A construção de uma questão: a mobilidade urbana na era do automóvel 28

capítulo 135

A trajetória do engenheiro-urbanista Colin Buchanan

Primeiras formulações sobre mobilidade 36

Traffic In Towns 39

A carreira como consultor 41

A difusão de um novo quadro conceitual 43

\section{capítulo 245}

Colin Buchanan e o contexto do debate urbanístico e da engenharia de tráfego norte americana nos anos 1950 e 1960

O quadro referencial urbanístico nos anos 196046 A vertente norte-americana da engenharia de tráfego 68

capítulo $3 \quad 81$

A mobilidade urbana como questão política

A opção pelo automóvel como modo de transporte urbano 82 A construção de uma nova forma de abordagem do problema da 92 mobilidade na esfera pública capítulo 4101

O fenômeno da circulação urbana

O conflito entre tráfego e cidade 102

A circulação motorizada como fenômeno urbano 107

O debate em torno do modelo radio-concêntrico 116

A questão das áreas centrais 127

capítulo 5137

A escala urbana local: a vizinhança e a rua

A escala da vizinhança 138

A escala da rua 147

capítulo 6161

A estrutura urbana e regional para o tráfego

O Estudo para South Hampshire 162

O conceito de estrutura urbana flexível 165

A discussão sobre a estrutura urbana 173

A estrutura urbana centrípeta 173

A estrutura urbana linear 177

A grelha como estrutura urbana 183

A trama direcional, a relação entre cidade e circulação e a dimensão regional 194

A trama direcional e a tensão entre modos públicos e privados 202

conclusão 207

bibliografia 215

livros e artigos 215

planos urbanos e de transportes 224 



\section{índice de imagens}

\section{Figuras}

Figura 1 pg. 29

Desconstrução dos elementos que compõem a rua, conforme Stephen Marshall

Figura 240

Equipe de Traffic in Towns (G. H. C. Cooper não aprece na foto)

Figura 353

Plano para Filadélfia, Louis Kahn - 1953-1956. Estudo de circulação

Figura $4 \quad 54$

Plano para Filadélfia, Louis Kahn - 1953-1956. Perspectiva da proposta para a área central

Figura $5 \quad 55$

Plano para Filadélfia, Louis Kahn - 1953-1956. Proposta para um edifício-garagem privado

Figura $6 \quad 56$

Plano para Filadélfia, Louis Kahn - 1953-1956. Croqui para área do Mercado Leste

Figura $7 \quad 57$

Vila Radiosa, Le Corbusier - 1933

Figura $8 \quad 58$

Cidade Helicoidal, K. Kurokawa -1961

Figura 959

Motopia, G. A. Jelicoe - 1961

Figura $10 \quad 60$

Harlow New Town - Frederick Gibberd -1947

Figura $11 \quad 61$

Harlow New Town - Frederick Gibberd -1947

Figura $12 \quad 61$

Harlow New Town - Frederick Gibberd -1947
Figura $13 \quad 63$

Hook New Town, London County Council - 1957

Figura $14 \quad 64$

Hook New Town, London County Council - 1957: area central

Figura $15 \quad 66$

Plano para Runcorn, Arthur Ling and Associates - 1967: vias exclusivas para ônibus e

vias expressas

Figura $16 \quad 67$

Plano Para Milton Keynes, Llewelyn-Davies Weeks Foresder-Walker \& Bor - 1970:

Sistema viário estrutural

Figura $17 \quad 67$

Plano para Runcorn, Arthur Ling and Associates - 1967: arranjo de uma área

habitacional polarizada por um ponto de parada de transporte coletivo sobre pneus

Figura $18 \quad 67$

Plano Para Milton Keynes, Llewelyn-Davies Weeks Foresder-Walker \& Bor - 1970:

conexão entre o sistema viário estrutural e as áreas habitacionais

Figura $19 \quad 70$

Southern State Parkway em 1927

Figura $20 \quad 71$

Grand Central Parkway, em janeiro de 1938, Nova York

Figura $21 \quad 74$

Futurama: Exposição "Highways and Horizons" - General Motors (Exposição

Internacional de Nova lorque de 1939), Norman Bel Guedes

Figura $22 \quad 75$

Imagem divulgada no livro You and Tomorrow's Roads - Esso Standard Oil Company, 1958

Figura $23 \quad 77$

Padrão para vias arteriais urbanas, conforme o Manual "A Policy on Arterial Highways in Urban Areas", de 1957 
Figura $24 \quad 86$

"Mixed Blessing: the motor in Britain", publicado em 1958 (Саpa)

Figura $25 \quad 94$

Aspectos da urbanização linear ao longo das vias rurais (Ribbon Development) - Great West Road, RU, 1951

Figura $26 \quad 96$

Jovens famílias em mudança para um subúrbio norte-americano logo após a II Guerra Mundial

\section{Figura $27 \quad 104$}

Pedestre em uma calçada na Inglaterra

Figura $28 \quad 110$

Traffic in Towns: diagrama de Desejos de Viagens para uma cidade pequena

Figura $29 \quad 114$

Traffic in Towns: origem do tráfego de passagem nas cidades inglesas

Figura 30117

Diagrama de um sistema viário estrutural para uma cidade conceitual

Figura $31 \quad 118$

Hierarquia de vias estruturais segundo Alker Tripp

Figura $32 \quad 120$

Pesquisa de Densidades de Tráfego no sistema viário estrutural de Londres, dia típico das $8 \mathrm{~h}-20 \mathrm{~h}$

Figura $33 \quad 122$

Diagrama do sistema viário estrutural proposto por P. Abercrombie e

J. Forshaw para o Plano de Londres em 1943

Figura $34 \quad 123$

Diagrama do sistema de espaços verdes proposto por P. Abercrombie e J. Forshaw para o Plano de Londres em 1943

Figura $35 \quad 124$

Diagrama do sistema viário estrutural proposto por P. Abercrombie para o Plano da Grande Londres em 1944

Figura $36 \quad 126$

Traffic in Towns: Diagrama de desejos de viagens por motivo de trabalho para a cidade de Leeds

Figura $37 \quad 126$

Traffic in Towns: Alternativas para sistema viário estrutural de Leeds, para os cenários de intervenções mínima, intermediária e plena

Figura $38 \quad 127$

Canterbury Traffic Study, Colin Buchanan\&Partners, 1970 - alternativas para sistema viário estrutura
Figura $39 \quad 128$

Radburn Layout, conforme Traffic in Towns

Figura $40 \quad 130$

Área ocupada pelo sistema viário e suas atividades atreladas em Los Angeles, EUA

Figura $41 \quad 131$

Traffic in Towns: área destinada aos pedestres prevista no estudo para a completa

transformação de uma área central de Londres

Figura 42133

Estacionamento de veículos na área central de Bath.

Figura $43 \quad 134$

Bath: a planning and transport study, Colin Buchanan \& Partners,1965 - Sistema viário principal e estacionamentos

Figura $44 \quad 135$

Plano para Cardiff: circulação viária e estacionamentos

Figura $45 \quad 135$

Distância média até os estacionamentos no centro de Edinburg

Figura 46139

Problema da infiltração de tráfego em áreas residenciais

Figura $47 \quad 140$

Conceito de "Precincts" segundo Alker Tripp

Figura $48 \quad 142$

Cardiff: Development and Transport Study, Colin Buchanan\&Partners, 1966 identificação da área central e áreas degradadas

Figura $49 \quad 142$

Cardiff: Development and Transport Study, Colin Buchanan\&Partners, 1966 -

identificação preliminar das environmetal areas

Figura 50143

Cardiff: Development and Transport Study, Colin Buchanan\&Partners, 1966 -

identificação das environmental areas e estabelecimento de diretrizes para sistema

viário estrutural

Figura $51 \quad 149$

Tipologia ABCD de sistema viário

Figura $52 \quad 150$

Exemplo de uma implantação urbana e seu sistema viário, conforme Le Corbusier

Figura $53 \quad 152$

Projeto para Fort Worth, Texas, EUA - Victor Gruen Associates, 1956 - Perspectiva da Rua de Pedestres 
Figura $54 \quad 152$

Projeto para Fort Worth, Texas, EUA - Victor Gruen Associates, 1956 - Modelo da Implantação

Figura 55153

Solução para a área central de Filadélfia - Municipalidade de Filadélfia, 1959

Figura $56 \quad 154$

Projeto para o concurso Berlin Hauptstadt, Alison e Peter Smithson - 1957. Perspectiva da relação entre sistema viário e a rede de circulação de pedestres

Figura $57 \quad 156$

Traffic in Towns: Alternativa para remodelação parcial da região da University College of London e do Museu Britânico (Bloomsbury) - Corte esquemático de um corredor comercial local

Figura 58157

Traffic in Towns: Alternativa para completa remodelação da região da University

College of London e do Museu Britânico (Bloomsbury) - corredor comercial

Figura $59 \quad 158$

Traffic in Towns: Alternativa para completa remodelação da região da University

College of London e do Museu Britânico (Bloomsbury)

Figura $60 \quad 158$

Traffic in Towns: Alternativa para remodelação parcial da região da University College of London e do Museu Britânico (Bloomsbury) - área desapropriada na primeira fase de implantação

\section{Figura $61 \quad 159$}

Plano de Londres, P. Abercrombie e J. Forshaw - 1943 - Proposta de para University

Precinct

Figura $62 \quad 160$

Bath: a planning and transport study, Colin Buchanan \& Partners, 1965

\section{Figura $63 \quad 160$}

Bath: a planning and transport study, Colin Buchanan \& Partners, 1965 - proposta para um edificio multifuncional com amplo espaço para estacionamento

Figura $64 \quad 163$

South Hampshire Study, Colin Buchanan\&Partners, 1966 - região Sul da Inglaterra e localização da Área de Estudo de South Hampshire

Figura $65 \quad 163$

South Hampshire Study, Colin Buchanan\&Partners, 1966 - identificação das áreas de estudo

\section{Figura $66 \quad 171$}

Projeto para o concurso Berlin Hauptstadt, Alison e Peter Smithson - 1957
Figura $67 \quad 174$

South Hampshire Study, Colin Buchanan\&Partners, 1966 - estrutura centrípeta

Figura $68 \quad 174$

Cidade nova teórica

Figura $69 \quad 175$

Rede de Cidades-Jardins proposta por Howard na $1^{\circ}$ Edição do seu livro

Figura $70 \quad 176$

Arquétipo Strong City Centre, proposto por Thomson

Figura $71 \quad 178$

Proposta para Cidade Linear elaborada por Arturo Soria y Mata

Figura $72 \quad 178$

Detalhe da Cidade Lienar de Arturo Soria y Mata

Figura $73 \quad 179$

Cidade linear típica na Bélgica, elaborada por Del Castillo em 1919

Figura $74 \quad 180$

Plano para Londres - Patrick Abercrombie, 1943

Figura $75 \quad 180$

Plano para Londres - Grupo MARS (1938-42)

Figura $76 \quad 181$

Arranjo das diferentes funções na escala regional linear

Figura $77 \quad 181$

Le Corbusier e sua proposta para uma estrutura regional linear

Figura $78 \quad 182$

South Hampshire Study, Colin Buchanan\&Partners, 1966 - relevo e infra-estrutura urbana na área de estudo

Figura 79184

South Hampshire Study, Colin Buchanan\&Partners, 1966 - estrutura urbana em trama

Figura $80 \quad 186$

Broadacre City - Frank Lloyd Wright

Figura $81 \quad 187$

Perspectiva de Broadacre city - Frank Lloyd Wright

Figura $82 \quad 187$

Vila Radiosa - Le Corbusier

Figura $83 \quad 189$

Comparação entre as malhas de Paris, Nova lorque, Buenos Aires e a proposta para

Vila Radiosa - Le Corbusier

Figura $84 \quad 190$

Projeto para Chandigarh - Le Corbusier, 1951 


\section{Figura 85191}

Conceito estrutural da Casa Dominó - Le Corbusier, 1914

Figura $86 \quad 192$

Zoneamento interno dentro de uma célula da estrutura em grelha

Figura $87 \quad 192$

Comparação entre a estrutura rádio-concentrica e em grelha, conforme Doxiadis

Figura 88193

Tendência a arranjos urbanos mais ordenados, conforme Doxiadis

Figura 89193

A apreensão em campo da Cidade de Los Angeles, conforme Kevin Lynch

Figura $90 \quad 194$

South Hampshire Study, Colin Buchanan\&Partners, 1966 - estrutura urbana em trama

direcional

Figura $91 \quad 195$

Hierarquia viária conforme o manual Roads in urban Areas

Figura 92197

South Hampshire Study, Colin Buchanan\&Partners, 1966 - hierarquia de vias e relação do sistema viário com os usos do solo

Figura 93198

Projeto para Chandigarh - Le Corbusier, 1951 - hierarquia viária

Figura $94 \quad 199$

South Hampshire Study, Colin Buchanan\&Partners, 1966 - unidade elementar de planejamento

Figura $95 \quad 200$

South Hampshire Study, Colin Buchanan\&Partners, 1966 - estrutura urbana

plenamente explorada para South Hampshire em 2001

Figura $96 \quad 201$

South Hampshire Study, Colin Buchanan\&Partners, 1966 - etapas parciais de ocupação em 1981 e 1991

Figura $97 \quad 202$

Kuwait: National Physical Plan and Master Plan for Urban Areas, Colin

Buchanan\&Partners, 1970 - estratégia urbana escolhida

Figura $98 \quad 203$

Estudo para Cardiff - circulação de pedestres e transporte público

\section{Gráficos}

Gráfico $1 \quad 70$

Registro de veículos, consumo de combustíveis, tributação e investimentos e novas

Highways nos EUA: 1910-1955

Gráfico $2 \quad 85$

Taxas de crescimento e previsão de crescimento da frota de veículos

Gráfico $3 \quad 115$

Relação entre o tamanho das cidades e a proporção atribuída ao tráfego de passagem

\section{Tabelas}

Tabela $1 \quad 66$

Taxa de motorização em cidades norte-americanas e européias em 1960

Tabela $2 \quad 74$

Características das vias arteriais urbanas, conforme o Manual "A Policy on Arterial

Highways in Urban Areas", de 1957

Tabela $3 \quad 82$

Pessoas empregadas pela cadeia produtiva ligada ao transporte sobre rodas na GrãBretanha. Ano base 1956

Tabela $4 \quad 82$

Pessoas empregadas por ramo de atividade na Grã-Bretanha. Ano base 1956 


"'How to live with the auto', or, if you will, 'How to live in spite of it" (STEIN, 1967: 41) 
resumo

Esta tese busca dar subsídios à compreensão da complexa relação entre cidade e seus sistemas de circulação, sobretudo a partir das diversas transformações urbanas ocorridas ao longo do século XX. É nossa hipótese que a obra do engenheiro-urbanista britânico Colin Buchanan, elaborada entre 1958 e 1966, constitui-se em um momento importante do debate acerca desta relação, sobretudo pelo deslocamento da ênfase das preocupações com a dinâmica da circulação urbana para questões relacionadas à cidade.

Neste movimento, Buchanan estabelece um forte posicionamento contra algumas correntes hegemônicas de planejamento de transportes que enfatizavam as questões construtivas ou privilegiavam análises de base econômica. Seu trabalho identifica uma clara opção pelo automóvel como modo de transporte e discute quatro questões urbanas fundamentais: 1) a mobilidade urbana como uma questão política; 2) a circulação urbana como fenômeno; 3) a escala urbana local; 4) a estrutura urbana e regional para o tráfego. Estas quatro dimensões, como foram denominadas neste trabalho, ancoram aquilo que consideramos a sua proposta de cidade para a era do automóvel. 


\section{abstract}

The object of this thesis is to provide subsidies for understanding the complex relationship between the city and its circulation systems, especially from the several urban transformations that have occurred over the twentieth century. It is our hypothesis that the work of the British engineer-planner Colin Buchanan, drafted between 1958 and 1966, constitutes an important contribution to the debate about this relationship, mainly by shifting the focus of concerns about traffic issues for the city.

In this movement, Buchanan makes a strong point of view against some hegemonic currents of transportation planning that emphasized the issues favored constructive or economic analysis. This work identifies a clear option for the car as a mode of transportation and discusses four key urban issues: 1) urban mobility as a political issue, 2) the movement as urban phenomenon, 3) the local urban scale, 4) urban structure and regional traffic. These four dimensions, as named in this work, support what we consider his proposal to the city for the automobile age. 


\section{introdução}

\section{A nova escala do problema do tráfego urbano em meados do século XX}

O período pós-segunda guerra mundial trouxe consigo um imenso esforço de reconstrução nos países europeus. O Reino Unido, embora bem menos afetado pelo conflito que seus vizinhos, também sofreu restrições ao desenvolvimento na segunda metade da década de 1940. No entanto, já nos anos 1950 a Europa assistiu um vigoroso processo de recuperação econômica e crescimento populacional.

Esta combinação, crescimento econômico e populacional, pavimentaria o caminho para uma expansão sem precedentes do automóvel na Europa - incluindo o Reino Unido, que será mais detalhadamente discutido neste trabalho. O fenômeno que ocorrera uma geração antes nos Estados Unidos era agora observado no velho continente.

Giedion (2004) menciona o surgimento de uma nova escala do planejamento urbano que ocorreu associado ao surgimento das vias parques norte-americanas nos anos 1930 e também à difusão do uso do automóvel. Em um discurso marcadamente corbusiano, o autor ressalta o avanço desta nova tipologia frente à rua tradicional e elogia a separação do tráfego entre pedestres e automóveis promovida pelas parkways.

A precedência norte-americana em relação à difusão do automóvel também é lembrada 
por Grubler (1990). Para ele, a disseminação deste meio de locomoção suplantou definitivamente o período dos veículos de tração animal no âmbito dos deslocamentos individuais, garantindo assim um seleto grupo de usuários, proprietários de automóveis. Curiosamente, as imagens das vias-parques em Giedion (2004) mostram justamente esta situação: vias recém-construídas abrigando poucos veículos.

É Grubler ainda que aponta que este "período norte-americano" corresponde ao primeiro surto de disseminação dos automóveis. O período posterior, iniciar-se-ia na década de 1950 e se estenderia até os anos 1980, atingindo escala mundial, com fortes impactos na Europa. Segundo ele, até a década de 1930, entre $80 \%$ e $90 \%$ da frota mundial de automóveis se encontrava nos Estados Unidos; este percentual cairia para 76\% no início da década de 1950, com tendência ainda mais acentuada de queda a partir deste período (GRUBLER, 1990). Neste cenário, o carro deixaria também de ser um bem para um grupo pequeno de pessoas e passaria a atingir uma parcela crescente das famílias.

Já em meados dos anos 1950, o crescente número de veículos era responsável pelo fenômeno do congestionamento de tráfego em alguns centros urbanos europeus. Ao mesmo tempo, era também, conforme Hall (2007), um agente do processo de suburbanização do velho continente, particularmente, do Reino Unido. Entre 1945 e 1975, a Europa ultrapassou os Estados Unidos, tornando-se o maior centro produtor de automóveis no mundo (HALL, 2007). Não por acaso, a expansão da frota de veículos foi sucessida pela queda no número de passageiros de transporte coletivo e aumento das tarifas nas décadas de 1960 e 1970: um fenômeno de escala mundial, segundo Thomson (1977).

No período anterior à II Guerra Mundial a circulação urbana já vinha sendo objeto de preocupação de arquitetos e urbanistas. Eugene Hernard, na França da virada do século XIX para o XX, já havia elaborado importantes considerações sobre este problema (HÉNARD, 1972). Le Corbusier e Frank Lloyd Wrigth, nos anos 1930, haviam também se debruçado sobre a questão. No Reino Unido, Patrick Abercrombie se empenhou para dar uma solução ao problema da "congestão" de Londres nos anos 1940. Assim como estes exemplos, muitos outros poderiam ser mencionados. 
A questão que diferencia esta segunda fase de difusão do automóvel, conforme a classificação de Grubler (1990), é fundamentalmente uma questão de escala. O problema neste momento assume uma dimensão sem precedentes na história das cidades; uma vez que à motorização, associa-se a urbanização e o crescimento populacional. Nos anos 1950 e 1960, a combinação destes três elementos coloca a própria viabilidade da cidade tradicional em xeque.

A situação britânica era bastante expressiva desta segunda fase da disseminação dos automóveis, embora no Reino Unido o fenômeno de urbanização fosse mais discreto quando comparado a outros países. Neste período, de fato, ocorreu uma intensa motorização do país, com forte impacto nas estruturas físicas das cidades, muitas vezes marcadas por seus tecidos urbanos tradicionais e seus espaços viários não adequados ao deslocamento motorizado.

Não por acaso, o engenheiro-urbanista britânico, Colin Buchanan, em um dos seus mais importantes trabalhos (BUCHANAN, 1963), fez um interessante prognóstico: alegou que o aumento do número de veículos e o congestionamento já eram uma realidade, e que o potencial de aumento de veículos era tão grande que, a menos que algumas medidas fossem tomadas, ou a utilidade dos automóveis entraria em declínio ou os ambientes urbanos se deteriorariam rapidamente. Para ele, provavelmente as duas coisas aconteceriam juntas.

Em paralelo, Secchi (2009) aponta que os fenômenos de concentração e dispersão urbanas se constituíram como etapas sucessivas na Europa, com ponto de inflexão nos anos 1960 e 1970. Assim, podemos admitir que o período que abordaremos neste trabalho sofreu ação combinada destes dois movimentos. Se por um lado, se percebia as conseqüências da concentração urbana e seus efeitos na dinâmica de circulação, por outro, sentia-se também os riscos que se avizinhavam a partir da dispersão indiscriminada, que tinha nos automóveis um forte elemento de contribuição e nos Estados Unidos um exemplo de suas conseqüências. 
Neste cenário de crescente presença dos automóveis e seu desdobramento nos tecidos urbanos, a questão da circulação urbana assumiu uma posição de proeminência na agenda dos profissionais envolvidos com a escala da cidade. Segundo Benévolo (2009a), tratava-se de um período particular, caracterizado pela oportunidade de projetos em grande escala para arquitetos, que trazia consigo as teorizações urbanísticas do período anterior.

De fato, este período foi marcado pela profusão de "projetos tese", abordando as questões de circulação urbana. Boaga (1977: 88) considera "la via automovilística como 'estructura' de las utopias urbanisticas modernas". Secchi (2009) lembra que as infraestruturas de mobilidade assumiram uma presença visual cada vez mais relevante. Reis Filho, (1967: 64) ressalta que entre os temas do $10^{\circ}$ Congresso Internacional de Arquitetura Moderna (CIAM) estiveram "mobilidade" e "crescimento e mudança", duas questões fortemente vinculadas ao automóvel.

Diante desta nova escala do problema da circulação urbana e de sua repercussão entre os profissionais preocupados com o futuro das cidades, a obra de Colin Buchanan tomou corpo, num discurso que enfrentou, de forma particular, esta questão e construiu uma resposta relevante no cenário do debate de urbanismo e transportes nos anos 1960.

\section{A construção de uma questão: a mobilidade urbana na era do automóvel}

No cenário descrito acima, Colin Buchanan consolidou uma resposta particular para a questão da circulação urbana entre 1958 e 1966. Neste período de oito anos, o engenheiro-urbanista britânico formulou três trabalhos que sintetizam sua trajetória e sua posição frente ao crescimento dos automóveis, bem como seu impacto nas cidades: 1) o seu livro Mixed Blessing: the motor in Britain; 2) o relatório elaborado para o governo britânico sob sua coordenação, intitulado Traffic in Towns: a study of the long term problems of traffic in urban areas; 3) o estudo desenvolvido para a região de South Hampshire. Estes 
três documentos constituem as principais bases conceituais de um raciocínio que se caracterizou pela busca constante de viabilizar a difícil relação entre automóvel e cidade.

Neste aspecto, o discurso construído por Colin Buchanan no período chama bastante atenção. Jacobs (1966; 2001) indica que os anos 1950 e 1960 foram marcados pela afirmação do papel da rua como lugar destinado à circulação, em detrimento às suas outras funções, como local de sociabilidade e de comércio, por exemplo.

Marshall (2005) avança sobre o tema, afirmando que esta supremacia da função de circulação esteve fortemente atrelada à progressiva distinção de atribuições profissionais. Assim, enquanto os engenheiros de tráfego e transportes se concentraram na dimensão dos deslocamentos, os planejadores urbanos se debruçaram sobre as questões referentes ao gerenciamento do uso do solo e dos espaços públicos distintos da rua e, finalmente, os arquitetos dedicavam-se à dimensão volumétrica dos edifícios. A figura abaixo esclarece a visão do autor sobre este ponto, traduzindo graficamente a polarização das três esferas de ação sobre a cidade e a rua'.

Este diagnóstico é, em linhas gerais, compartilhado por Vasconcellos (2000). Para ele existem três esferas de ação sobre a questão da mobilidade urbana: o planejamento urbano, o planejamento de transportes e o planejamento da circulação. Enquanto o primeiro define as estratégias de uso do espaço, o segundo se concentra na infra-estrutura que permite o deslocamento de pessoas e mercadorias e, finalmente o terceiro, age no gerenciamento dos usos destas infra-estruturas. Vasconcellos também ressalta a dificuldade de diálogo entre estas três esferas. Segundo ele, a abordagem da circulação de automóveis teria predominado sobre as demais esferas, com forte influência da engenharia de tráfego norte-americana.

A supremacia da função de circulação nos anos 1950 e 1960 é bastante ressaltada por Hall (2007). Segundo ele,

1 Ao que tudo indica, este autor não se refere à produção teórica deste período, mas sim à prática profissional destes anos. 
"Por mais de uma década, de meados dos anos 50 em diante, uma nova geração de analistas do tráfego chegou para dominar o planejamento urbano, primeiro nos Estados Unidos e, em seguida - à medida que se exportavam a si próprios e às suas técnicas -, também na Europa. Seus modelos computadorizados surgiram para demonstrar a necessidade inexorável de se construírem vastas malhas de novas auto-estradas urbanas aptas a fazerem face à curva ascendente do volume de tráfego. Durante certo tempo, não encontraram resistência." (HALL, 2007: 373)

Hall (2007) inclui nesta categoria o próprio Colin Buchanan e o relatório Traffic in Towns. Acreditamos, no entanto, que a análise deste autor desconsidera uma importante dimensão do trabalho do engenheiro-urbanista britânico.

Neste contexto de crescente relevância das questões da circulação e suas demandas de desempenho, Buchanan construiu uma visão fortemente calcada na dimensão da cidade. Neste sentido, a análise de Vasconcellos (2000) nos parece mais apropriada. O autor aponta que, enquanto para a engenharia norte-americana o conflito se dava entre a fluidez e segurança, para Buchanan o conflito ocorria entre acessibilidade e cidade ${ }^{2}$.

Colin Buchanan esteve plenamente inteirado das novas técnicas de planejamento de transportes, apontadas por Hall (2007). Utilizou, tanto em Traffic in Towns como em seus trabalhos como consultor, as técnicas computadorizadas de simulação de carregamentos e de viagens, disponíveis em sua época. Ao mesmo tempo, sua trajetória profissional, anterior ao período focado neste trabalho, o habilitava plenamente nas questões relativas à engenharia de tráfego e ao projeto de vias. Mas, como advertia o relatório Traffic in Towns:

“(...) This means that unless something is done the conflict between towns at the present arranged and motor vehicles as at present used is bound to get progressively worse. It can

2 Neste caso, vale a pena ressaltar que a noção de acessibilidade empregada aqui não tem relação com o uso deste mesmo termo para designar acessibilidade universal às edificações, em especial para pessoas portadoras de restrições permanentes ou temporárias. 
be said categorically that the potential numbers of vehicles in towns are beyond anything that could be dealt with by one-way streets, waiting prohibitions, of other manipulative measures" (BUCHANAN, 1963: 29)

Como se percebe na citação acima, para Buchanan os problemas observados naquele momento não se resolveriam no âmbito exclusivo da esfera da engenharia dos transportes - área que conhecia muito bem. Assim, interessa neste trabalho destacar a construção de um discurso que propõe a esfera da cidade como dimensão fundamental na teoria e prática dos aspectos relativos à circulação urbana. Entendemos que é neste aspecto que a contribuição de Colin Buchanan mais se destaca: o esforço teórico de definição das formas de inteiração entre cidade e circulação. É neste terreno que nosso trabalho se situa e é por esta razão que esta tese se esforça em recuperar o discurso do engenheiro-urbanista britânico.

A análise da obras de Colin Buchanan, em particular daquelas compreendidas no período entre 1958 e 1966, nos indica que a preocupação com a esfera da cidade se concentra em quatro aspectos, denominados neste trabalho de dimensões. Cada uma destas quatro dimensões será tratada em um capítulo específico e constitui o corpo principal deste trabalho.

Os dois capítulos iniciais cumprem a função de apresentação de um quadro contextual das principais questões abordadas. No primeiro capítulo, recuperamos a carreira profissional de Colin Buchanan, procurando mostrar os aspectos de sua trajetória profissional que o fizeram um engenheiro-urbanista. No segundo capítulo, buscamos construir um panorama da produção teórica e prática contemporânea ao período em destaque nesta tese. A análise, neste caso, se concentra em duas das principais referências da obra do engenheiro-urbanista britânico: o debate sobre urbanismo e os principais contornos da vertente norte-americana da engenharia de tráfego.

$\mathrm{Na}$ sequência, a partir do capítulo 3, iniciamos a discussão sobre as quatro dimensões elaboradas a partir da análise da obra de Buchanan. A primeira dimensão diz respeito 
ao reconhecimento da cidade como esfera em que se dá um embate político. Ao reconhecer este aspecto, Buchanan se distanciava das vertentes que entendiam o planejamento, em suas diferentes modalidades, como situado no âmbito exclusivo da esfera da técnica. Ao mesmo tempo, traçava uma defesa entusiasmada do automóvel como um modo imbatível de transporte urbano. Ao realizar esta defesa, ele mesmo se posicionava politicamente em relação ao debate sobre a circulação nos anos 1960.

A dimensão política se assentava também na proposta de uma nova forma de ação do Estado. Ancorado em um discurso em que ressaltava a separação histórica entre planejamento urbano e planejamento de transportes e circulação, Buchanan construiu um enfoque que tratava a nova situação do automóvel na sociedade da época como determinante para uma nova forma de gerenciamento desta questão, em que o Estado deveria assumir um novo posicionamento. Esta dimensão específica da questão urbana na obra de Colin Buchanan será tratada no capítulo 3.

A segunda dimensão será mais detalhadamente tratada no capítulo 4. Neste caso, interessa destacar o esforço de formulação teórica sobre a natureza do fenômeno da circulação de veículos no meio urbano e de suas conseqüências a partir do aumento da frota de automóveis. Se a opção foi por este modo de transporte, havia que se investigar profundamente as suas relações com a cidade, como forma de viabilizar a opção política tomada. Em outras palavras, garantir a sobrevivência das cidades era assegurar o automóvel como modo de transporte.

A terceira e a quarta dimensões da questão urbana da circulação, respectivamente tratadas nos capítulos 5 e 6 , construíram uma relação bastante estreita com o debate da arquitetura e urbanismo dos anos 1950 e 1960. O discurso do Movimento Moderno, sua contestação e sua revisão não passaram ao largo da obra do engenheiro-urbanista. Ao mesmo tempo, o Reino Unido era palco de um ambicioso programa de novas cidades, que colocava o debate sobre as cidades ainda mais em evidência. Este conjunto de referências esteve a todo o momento sendo acionado. Neste aspecto, Colin Buchanan foi menos um formulador do debate e mais um observador atento destas várias correntes 
que se apresentavam neste período.

Colin Buchanan destacou a questão da escala local urbana como elemento fundamental para a solução do problema da circulação. Esta terceira dimensão se ancorou no debate emergente sobre o desenho urbano nos anos 1960. Na escala da vizinhança, seu trabalho se destaca pela busca de estabelecimento de padrões ambientais como condicionantes do volume de tráfego, numa clara contraposição à emergência dos critérios de desempenho propostos pela engenharia norte-americana e das análises custo-benefício desenvolvida pelos economistas. Na escala da rua, sua preocupação chama atenção pela incorporação do projeto urbano como forma de viabilizar os conflitos entre automóveis e pedestres, configurando uma resposta que ultrapassava os parâmetros técnicos da engenharia de projetos de vias.

Ao mesmo tempo, na quarta dimensão da questão urbana da circulação, Buchanan desenvolveu uma importante investigação sobre a estrutura urbana desejável para a era do automóvel. No Estudo para South Hampshire (1964-1966), ocasião em que sintetizou esta preocupação, o engenheiro-urbanista dialogou com diferentes tradições urbanistas e as ponderou tendo as demandas impostas pelo automóvel como elemento de parâmetro.

Estas quatro questões particulares, ou dimensões como propomos neste trabalho, evidenciam a cidade como uma questão central no discurso de Colin Buchanan. Em um contexto de progressiva separação das atribuições profissionais, o engenheiro-urbanista britânico reforçava uma posição que abordava a questão da circulação urbana de maneira abrangente, não a restringindo nem às demandas de desempenho e nem à exclusão do automóvel da cena urbana. Na obra de Colin Buchanan, viabilizar a cidade era ao mesmo tempo viabilizar a presença do automóvel.

Neste sentido, o raciocínio de Buchanan caminha para o que convencionou chamar de mobilidade urbana, entendida como resultado da interação entre os deslocamentos de pessoas e bens com a cidade e suas infra-estruturas de transportes. Embora Potter (1976) ressalte que o termo mobilidade urbana só tenha sido empregado a partir de meados 
dos anos 1960, acreditamos que a obra de Colin Buchanan entre 1958 e 1966, mesmo sem o mencionar, tenha colocado este conceito em pauta e contribuído bastante para sua definição. De fato, Colin Buchanan contribuiu para o debate de sua época e formulou um projeto particular para a mobilidade urbana na era do automóvel.

Ao mesmo tempo, o discurso construído por Buchanan, seja por meio de seus escritos ou de seus planos e estudos, não deixa de expressar contradições e fragilidades, típicas dos momentos de formulação de novos quadros conceituais. A análise de seus trabalhos mostra que suas formulações sofreram revisões ao longo de sua trajetória profissional e até mesmo sua aposta no deslocamento por automóveis foi relativizada.

Ao recuperar a obra de Buchanan a partir das dimensões mencionadas, esta tese tem por objetivo colaborar para a construção de um referencial para a análise do problema da circulação urbana que se apresenta nos dias de hoje, particularmente nos países em desenvolvimento como o Brasil, onde se observam crescentes taxas de motorização.

Considerando as condições atuais da relação entre cidade e tráfego de automóveis no Brasil, caracterizada pelo crescimento da frota veicular e seu vasto impacto nos tecidos urbanos, acreditamos que a recuperação da obra de Colin Buchanan pode nos fornecer subsídios importantes para repensar o problema da circulação urbana de maneira alternativa ao modelo que, infelizmente, ainda prevalece na situação brasileira ${ }^{3}$.

3 As recentes obras implantadas pelo Estado no Brasil, como por exemplo a ampliação da Av. Marginal do rio Tietê, na cidade de São Paulo, nos mostra que o modelo aqui criticado está longe de sua superação. 


\section{capítulo 1}

\section{A trajetória do engenheiro-urbanista Colin Buchanan}

Neste capítulo procuramos recuperar a trajetória profissional de Colin Buchanan. O objetivo é apresentar claro, a partir de suas principais obras, o engenheiro-urbanista como personagem da construção de um caminho consciente na direção da compreensão das questões da circulação e suas relações com as cidades.

A trajetória profissional de Colin Buchanan mostra um longo caminho de formação até a publicação de seu primeiro livro em 1958 (Mixed Blessing: the motor in Britain), que apresenta uma primeira síntese sobre as questões da mobilidade urbana. Neste intervalo de aproximadamente 30 anos, ele atua basicamente como membro técnico da burocracia britânica, o que lhe permite acumular um sólido conhecimento sobre a política pública setorial de transportes e planejamento urbano.

Nestes anos, interessa também seu esforço pela ampliação de sua formação como engenheiro, estendendo suas habilidades para a compreensão da cidade e do urbanismo. A sua qualificação como urbanista, junto ao Town Planning Institute, e como arquiteto, junto ao Royal Institute of British Architects, demonstra um caminho consciente no sentido de uma síntese das questões da engenharia e do urbanismo.

Os anos 1960 são de notoriedade pública para Buchanan. A construção do caminho 
mencionado permite uma atuação profissional que se pauta pela articulação das áreas de planejamento urbano e transportes, filtradas pela noção da dimensão política das escolhas no campo da mobilidade.

A partir de seu mais conhecido trabalho, o relatório Traffic in Towns: a study of the long term problems of traffic in urban areas, Colin Buchanan inicia uma bem sucedida carreira como consultor e se afirma como uma das mais importantes personalidades nas áreas de planejamento urbano e transportes.

\section{Primeiras formulações sobre mobilidade}

Após sua graduação como engenheiro civil, Colin Buchanan iniciou sua atividade profissional com uma rápida passagem por Uganda, trabalhando para o Public Works Department. De volta ao Reino Unido, teve outra experiência profissional breve, mas extremamente significativa. Nesta ocasião, trabalhou para uma consultoria de planejamento urbano em Essex, onde começou a se interessar pelo tema. Esta experiência o fez submeter-se aos exames do Town Planning Institute em 1935, onde foi aprovado, qualificando-se como urbanista.

Deixou a consultoria para assumir uma posição estável no Divisional Road Engineer's Office em Exeter. Seu trabalho consistia em analisar os projetos viários que buscavam financiamento junto ao Ministério dos Transportes, além de auditoria de acidentes de trânsito. Segundo ele, sua forma de trabalho não deixava de incomodar seus colegas engenheiros, pois a sua análise incluía considerações sobre possíveis desdobramentos quanto ao desenvolvimento urbano (BUCHANAN, 2002).

Esta experiência profissional o fez escrever um livro, nunca publicado, intitulado "Let us take the Road”. Em 1937, por iniciativa própria, visitou as Autobahns alemãs, tendo ficado bastante entusiasmado: "Everything had been designed together - the carria- 
geway surfaces, the Grass verges, the parking areas paved with granite setts, the filling stations, the viaducts, the direction signs" (BUCHANAN, 2002: 9).

Na II Guerra Mundial, durante quatro anos e meio, Buchanan esteve no sul do Sudão, servindo como Coronel do exército britânico, construindo pontes. Durante estes anos, nas horas vagas, se preparou para o exame admissional do Royal Institute of British Architects e assim que retornou para a Inglaterra submeteu-se à prova e mais uma vez foi aprovado.

Esta insistência pelo enquadramento como urbanista não deixa de chamar atenção e, de fato, o qualificou com um perfil bastante interessante, que poderíamos chamar de engenheiro-urbanista. Este período inicial de formação de Colin Buchanan o conduziria a uma forma de análise muito particular do problema do automóvel na cidade, que nos anos do pós segunda guerra se tornaria mais evidente.

Após o serviço militar na II Guerra Mundial, Colin Buchanan retornou para o Divisional Road Engineer's Office em Exeter. Segundo ele, ficou evidente que seu interesse havia mudado: das questões da engenharia e da segurança rodoviária, para a cidade de Londres, onde um intenso debate urbano se processava (BUCHANAN, 2002). Era o momento das discussões em torno do plano de Patrick Abercrombie e sua proposta de realocação de um milhão de habitantes e dos New Town Act e Town and Country Planning Atc, que deram ao plano o suporte legal para implementação de parte das propostas. Em resumo, tratava-se da emergência de um Estado forte no papel intervencionista de planejador, não só da economia, mas também do destino das cidades.

Era a cidade o principal foco do problema do crescimento dos automóveis. Diante desta constatação, Colin Buchanan mudou-se para Londres, o principal centro deste debate no Reino Unido. De início, transferiu-se para a sede do Ministério dos Transportes para mais tarde ser alocado no recém criado Ministério do Planejamento Urbano e Regional (Town and Country Planning Ministry), onde “(...) all the complex problems of designing new towns and rebuilting the blitzed cities would come my way" (BUCHA- 
NAN, 2002: 20). Curiosamente, enquanto Buchanan se inseria no local onde queria trabalhar, muitos de seus colegas o deixavam para participarem dos projetos das New Towns em curso. Muitos deles eram arquitetos e alguns ainda haviam trabalhado com Abercrombie no plano de 1944.

A passagem pelo Ministério do Planejamento Urbano e Regional em Londres foi rápida e logo no final de 1946, Colin Buchanan se transferiu para o escritório regional do Ministério em Reading, uma cidade a oeste de Londres. A função deste órgão era operar como um articulador das ações dos ministérios dos transportes e do planejamento. Embora demonstrasse preferência por esta função (BUCHANAN, 2002), as dificuldades não tardariam a aparecer. Esta experiência, embora curta, marcaria muito fortemente a construção de seu discurso sobre mobilidade.

Os problemas de deslocamento pessoal entre Londres e Reading trouxeram Buchanan de volta à capital, agora trabalhando na London Division Section, ligada ao mesmo ministério. Este órgão tinha basicamente a função de acompanhamento da implementação e de inúmeras modificações no Plano para a Grande Londres, de Patrick Abercrombie.

A insistência de Colin Buchanan em um caminho "autônomo", buscando uma maior relação entre planejamento urbano e as questões de tráfego, rendeu a ele o estigma de "não talhado" para o planejamento urbano. Assim, novamente foi realocado, agora na divisão de Inspetores do Ministério, cujo trabalho era emitir pronunciamentos confidenciais ao Ministro, a respeito de divergências entre a legislação urbana e a de habitação. Se o trabalho nesta seção era enfadonho, como admitiu, tinha a virtude de liberá-lo de extensas jornadas de trabalho.

O tempo livre passou a ser dedicado à sistematização de suas idéias à respeito da circulação e dos automóveis. Embora este período de mais de dez anos (entre o retorno da II Guerra e 1958, quando escreve Mixed Blessing) seja repleto de idas e vindas por repartições públicas, Buchanan não deixou de ser uma profissional da burocracia estatal britânica. De fato, neste momento, o engenheiro-urbanista construiu uma visão 
de mobilidade, baseada na compreensão do automóvel e seu impacto nas cidades, mas, sobretudo o desdobramento desta realidade como conseqüência de uma política de Estado. Foi esta experiência que lhe conferiu as bases para a redação de seu primeiro livro publicado: "Mixed Blessing: The motor in Britain".

A estratégia de Buchanan parecia clara. Se a inserção no debate da mobilidade urbana, como ele vinha buscando desde que retornou do serviço militar, não parecia ser possível galgando posições na burocracia, seria então pela via da sistematização teórica que ele passaria a buscar presença na discussão.

“(...) Even if no-one in the Ministry was prepared to take as interest in my views on roads and traffic and the relationship to planning, I decided nevertheless that it might be worth putting them down in writing, perhaps even as a book. (...)" (BUCHANAN, 2002, 39-40)

Embora Mixed Blessing não tenha tido grande repercussão, como admite o próprio Colin Buchanan, este livro pavimentou o caminho para seu mais conhecido trabalho: Traffic in Towns, que será discutido na sequência.

\section{Traffic In Towns}

No final dos anos 1950, os problemas relacionados ao tráfego vinham se agravando e, neste sentido, Mixed Blessing parecia se encaixar perfeitamente nas preocupações do então Ministro dos Transportes, Ernest Maples. O contato do Ministro com o livro de Buchanan ocorreu de forma casual. Marples o leu durante uma viagem de avião e procurou conhecer o autor do livro ${ }^{5}$, que, curiosamente, trabalhava no mesmo edifício que ele.

4 Mixed Blessing pode ser lido como "faca de dois gumes"

5 Esta passagem da história de Colin Buchanan foi contada por seu filho Malcolm Buchanan, em entrevista ao autor $(21 / 11 / 2008)$. 
Marples então decidiu pela elaboração de um estudo sobre o impacto dos automóveis nas cidades britânicas e designou Buchanan para sua elaboração em julho de $1960^{6}$. O engenheiro-urbanista assumiu a coordenação da equipe de trabalho, com total liberdade para a escolha dos seus componentes, mas com a supervisão de um grupo diretivo, sob responsabilidade de Geoffrey Crowther. A configuração desta forma de trabalho não se deu sem alguns embates dentro da burocracia do ministério. Mas, finalmente, Buchanan conquistava então a oportunidade pela qual havia esperado durante anos.

A equipe de trabalho foi composta por oito pessoas: o engenheiro de vias e planejador urbano G. H. C. Cooper; a arquiteta e urbanista Anne MacEwen, que havia trabalhado por doze anos no London County Council; o arquiteto e urbanista D. H. Crompton, que havia trabalhado no Ministério de Planejamento Urbano e Regional, e como professor da Universidade de Liverpool; o engenheiro de tráfego Geoffrey Crow, que havia trabalhado na cidade nova de Cumbernauld; o arquiteto Gordon Mitchell; o engenheiro de tráfego Peter J. Hills; o economista David Dallimore; e, finalmente, o ainda estudante de arquitetura da Architectural Association, Derry Burton.

Colin Buchanan parecia reconhecer o caráter polêmico e a grande repercussão que viria a ter o relatório produzido por ele e sua equipe. Juntamente com Ernest Marples, cuidou para que o trabalho fosse publicado pela HSMO (Her Majesty's Stationery Office), com uma formatação especial, incluindo muitas ilustrações em cores, o que não era uma prática comum da editora oficial britânica.

Traffic in Towns foi publicado em 27 de novembro de 1963 e demonstrou que Buchanan estava certo em relação ao potencial de repercussão do relatório: poucos meses após sua divulgação, até o início de 1964, os exemplares produzidos pela HSMO venderam 17 mil cópias. No mesmo ano, graças ao sucesso obtido, a editora Penguin, famosa por sua extensa lista de títulos vendidos a preços populares, publicou uma versão reduzida do

6 Colin Buchanan foi cedido pelo Ministério de Habitação e Governo Local ao Ministério dos Transportes.

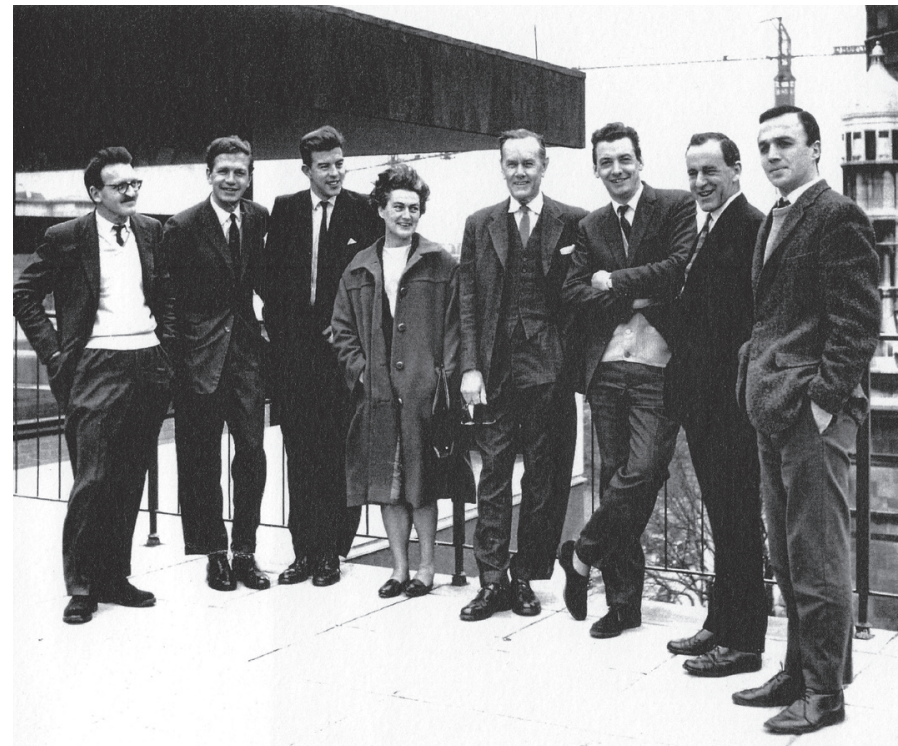

Figura 2: Equipe de Traffic in Towns (G. H. C. Cooper não aprece na foto)

Fonte: BUCHANAN, 2002: 66 
relatório. Traffic in Towns ganharia também versões em alemão ${ }^{7}$, espanhol e francês.

Com a conclusão do Relatório, Colin Buchanan rapidamente ganhou notoriedade. A este respeito, Hall (2004) apresenta uma interessante consideração:

"After the Report, Buchanan was Britain's most famous planner. In fact it would be fair to say that he was Britain's most famous planner ever. Abercrombie, who might have competed with him, suffered from the fact that his reports had to compete with war news in four-page newspapers and with television shut down for the duration of the conflict. (And in any case, there were only 10.000 potential viewers.) But 1963 was already well into the television age, and he was the first British planner to receive the full media treatment." (HALL, 2004: 10)

Este período coincidiu justamente com sua aposentadoria como servidor público em 1963. Estavam, portanto, abertas as possibilidades para o estabelecimento de uma carreira como consultor, além de outras incursões. Sobre esta nova fase da carreira de Colin Buchanan trataremos a seguir.

\section{A carreira como consultor}

Antes mesmo da conclusão de Traffic in Towns Buchanan vinha sendo chamado para dar pareceres sobre problemas relacionados ao tráfego em cidade britânicas. No ano de 1964 ele montou a empresa de consultoria em transportes e planejamento urbano chamada Colin Buchanan \& Partners, contando com praticamente a mesma equipe do Relatório e mantendo ainda o mesmo enfoque metodológico.

Ao mesmo tempo, foi convidado para assumir a nova cadeira de transportes na Impe-

7 A edição alemã de Traffic in Towns é de 1964. Conforme Ward (2002: 241) o relatório de Buchanan e sua equipe foi estudado profundamente pelos planejadores alemães. 
rial College; criada, ao que tudo indica, como um desdobramento dos debates surgidos a partir da publicação de Traffic in Towns. Permaneceu como docente durante três anos, até que suas ocupações como consultor comprometessem sua carreira acadêmica. Junto com ele, quatro dos membros da equipe do relatório passaram a integrar o mesmo corpo docente, permanecendo nesta universidade mesmo depois da saída do engenheirourbanista ${ }^{8}$. Colin Buchanan faria outra rápida incursão pela docência entre 1973 e 1975, como diretor da School of Advanced Urban Studies, na Bristol University.

No entanto, Buchanan se destacaria mesmo no papel de consultor. Rapidamente seu escritório se estabeleceu como uma das principais referências neste ramo de planejamento no Reino Unido. O volume e a importância dos trabalhos cresceram rapidamente e, no final dos anos 1960, já alcançavam encomendas no exterior. O escritório montado a partir da encomenda da cidade histórica de Bath, desenvolveu trabalhos também para Cardiff, Canterbury, Edinburgh, Guildford, Oxford, na Inglaterra; além de Marseille, Mônaco, Nantes, OsIo, Bilbao, Calais, Ankara, Arras, Avignon, Kuwait, Nairóbi, entre muitas outras cidades.

Também neste momento o escopo de atividade do escritório se ampliou:

"The scope of the partnership's work has widened to cover every scale and aspect of social, economic, land use and transportation planning - from architectural design to studies at national and regional levels" (PORTFÓLIO CB\&P, década de 1970).

Ao mesmo tempo, junto com as encomendas do escritório, Colin Buchanan construiu também uma inserção política setorial sólida, não somente no Reino Unido, mas também no exterior. Foi presidente do Royal Town Planning Institute (1964), onde também foi reconhecido com a Medalha de Ouro em 1967. No mesmo período foi vice-presidente do Royal Institute of British Architects, além de membro do Institute of Civil Engineer e do Ins-

8 Não foi possível, nos limites desta pesquisa, avaliar até que ponto as idéias de Traffic in Towns estiveram presentes na filosofia da universidade. Destacamos, no entanto, que o programa de pós graduação desta instituição foi, desde aquele momento, objeto de bastante reconhecimento no Reino Unido. 
titute of Transport. Nos anos 1970, foi consultor do Banco Mundial e da Fundação Ford em trabalhos para Calcutá e Islamabad.

\section{A difusão de um novo quadro conceitual}

Como vimos, após a publicação do relatório Traffic in Towns, Colin Buchanan ganhou rapidamente notoriedade, fazendo com que suas teses a respeito da mobilidade urbana na era do automóvel fossem disseminadas também no âmbito da teoria de urbanismo.

O reconhecimento da importância do discurso de Buchanan a partir dos anos 1960 pode ser aferido pela relevância de alguns autores que o tem mencionado em suas obras, entre eles Benévolo (2009 e 2009a), Boaga (1977), Choay (2003), Hall (2002, 2004 e 2007), Banham (1978), Secchi (2009) e Lynch (1981). Mais recentemente, Marshall (2005) recupera a importância de sua obra, ressaltando que:

"The Buchanan Report was not just an exercise in accommodating traffic in towns, nor a showcase for the possibilities of 'traffic architecture'. It presented a fundamental 'code' for urban structuring, based on the road system. While plans for superhighways and slab blocks have long fallen by the wayside, Buchanan's basic code remains: the core principles for the layout and 'hierarchy' of roads, and their relationship with building frontages and urban structure, live on in current theory and practice. In a significant way, we still build towns this way". (MARSHALL, 2005: 10)

No Brasil, a obra Buchanan foi mencionada com relevância por Vasconcellos (2000) e Deák (2001), além de Wilhein (2003). Além destes, ressalta-se que o já famoso Buchanan Report era de conhecimento de vários profissionais envolvidos com o planejamento viário durante os anos 1960 e 1970, entre eles o arquiteto e professor Witold Zmitrowicz ${ }^{9}$.

9 Witold Zmitrowicz foi durante muitos anos um dos responsáveis pela área de planejamento viário na Prefeitura de São Paulo e atualmente é professor da Escola Politécnica da USP. Estas informações foram obtidas em conversas informais durante a disciplina ministrada pelo professor na Escola Politécnica. 
Jorge Wilhein o acompanhou em uma visita a São Paulo em 1966, quando o engenheiro-urbanista britânico esteve no Brasil para ministrar uma palestra no Instituto de Engenharia de São Paulo ${ }^{10}$. A passagem de Buchanan pela cidade neste período não parece ser ao acaso. Conforme Vasconcellos (1999), os anos 1960 foram marcados pela constituição da "questão trânsito", fruto do vigoroso aumento dos índices de congestionamento na cidade.

Em paralelo, Deák (2001: 19) considera o Estudo para South Hampshire como um dos planos urbanísticos mais célebres daquele período. O autor destaca ainda a marcante influência da malha direcional, adotada em South Hampshire Study, no plano para Paulínea de 1968, de autoria de Wilhein, contando com a participação do próprio Deák.

A trajetória do engenheiro-urbanista britânico, bem como a repercussão de sua obra teórica e prática consolidaram a construção intencional de uma carreira com perfil particular. Neste sentido, interessa investigar como este caminho profissional interagiu com o debate contemporâneo, sobretudo a partir de duas fortes referências: o debate sobre urbanismo dos anos 1950 e 1960 e a vertente norte-americana da engenharia de tráfego. Discutiremos esta questão na sequência.

10 Depoimento ao autor em 27/01/2010. 


\section{capítulo 2}

\section{Colin Buchanan e o contexto do debate urbanístico e da engenharia de tráfego norte americana nos anos 1950 e 1960}

Neste capítulo buscamos recuperar o contexto dos anos 1950 e 1960, particularmente no que diz respeito à discussão de idéias no campo do urbanismo e da engenharia de transportes. O objetivo é situar a obra de Colin Buchanan neste quadro, investigando a repercussão das idéias deste momento em sua teoria e prática profissional, bem como verificando possíveis influências de suas idéias neste debate.

A obra de Colin Buchanan se encontra em profunda sintonia com o debate nos campos dos transportes e do planejamento urbano. Em um cenário, como nos anos 1960, de progressiva especialização destas áreas de conhecimento, o engenheiro-urbanista assume uma posição de síntese destes discursos, como forma de assegurar uma visão abrangente do problema do automóvel na cidade.

Neste sentido, interessa verificar o contexto destes debates em que a atuação profissional de Buchanan se insere. No campo do urbanismo, os anos 1950 e 1960 são marcados pela revisão da tradição modernista da Carta de Atenas e pela profusão de soluções utópicas para a questão da circulação urbana. Ao mesmo tempo, no Reino Unido, há um intenso 
debate propiciado pelo ambicioso programa governamental de construção de 32 novas cidades. Este cenário é acompanhado por Buchanan e incorporado em seus trabalhos.

O debate de transportes nestes anos é profundamente influenciado pelo que pode ser denominado de uma "tradição" norte-americana na engenharia de tráfego. O discurso de Buchanan também reconhece esta importância, mas assume a sua insuficiência para a resolução do problema do automóvel na cidade.

\section{O quadro referencial urbanístico nos anos 1960}

Em seu mais conhecido manifesto, a Carta de Atenas, o Urbanismo Modernista da vertente corbusiana aponta com entusiasmo as inúmeras possibilidades da circulação motorizada. Neste cenário, a "velha" rua da cidade tradicional não encontrava mais espaço. Ela era incompatível com as demandas impostas pelas novas características da circulação mecanizada, em especial a velocidade e as poluições sonora e do ar.

A trama formada pelas vias na cidade tradicional, repleta de interseções, era considerada um enorme obstáculo ao desempenho dos novos modos de circulação. A idéia de um tecido urbano organizado em blocos de edifícios, com suas fachadas voltadas para a rua era assim o principal alvo das críticas da Carta no que diz respeito à circulação. Ficava também clara a incompatibilidade entre a circulação de automóveis e pedestres. O texto da Carta declarava:

“(...) Traffic will be separated by means of a network of footpaths for the slow-moving pedestrian and network of fast roads for automobiles. Together these networks will fulfill their function, coming close to housing only as occasion demands" (LE CORBUSIER, 1973: 57).

Contra o modelo tradicional da rua e da cidade era então proposta uma cidade organizada em zonas distintas funcionalmente, classificadas por áreas habitacionais, de trabalho, 
de lazer e circulação. À última, no entanto, era atribuído um papel especial de ligação entre as demais funções:

“(...) the key functions - housing, work, recreation - zoning will introduce a measure of order into urban territory. The fourth function, that of traffic movement, should have only one objective: to bring the other three into effective communication with one another. Major transformations are inevitable (...)" (LE CORBUSIER, 1973: 98).

Este novo sistema viário, além de garantir a efetiva comunicação entre as outras três funções, contaria ainda com diferenciações, de acordo com seu papel na circulação urbana: "residencial roads, promenades, throughways, principal thoroughfares" (LE CORBUSIER, 1973: 85). Tratava-se, acreditamos, de uma proposta pioneira de hierarquização viária, ao lado do contemporâneo plano para a Vila Radiosa, de Le Corbusier.

Choay (2003) enquadra a produção da vertente corbusiana como "modelo progressista": um desdobramento dos ideais do século XIX, em que a razão e o progresso eram tidos como o destino do homem. Atualizado a partir do primeiro pós guerra, este modelo seria pautado pela idéia de modernidade, na qual o automóvel seria um personagem importante:

“A partir de 1928 o modelo progressista encontra seu órgão de difusão num movimento internacional, o grupo CIAM, em 1933, esse grupo propõe uma formulação doutrinária sob o nome de Carta de Atenas. Esta constitui, portanto, o bem comum dos urbanistas progressistas. (...) A idéia-chave que subentende o urbanismo progressista é a idéia de modernidade. (...). A grande cidade do século XX é anacrônica, porque não é contemporânea verdadeira nem do automóvel, nem das telas de Mondrian: eis o escândalo histórico que eles vão denunciar e tentar suprimir"' (CHOAY, 2003: 19-20).

Barone (2002) lembra também que mesmo internamente, nos Congressos Internacionais de Arquitetura Moderna (CIAMs), houve um embate entre as vertentes francesa e alemã, e que a primeira construiria uma posição hegemônica ao longo das oito primei- 
ras edições destes congressos. Neste sentido, a Carta de Atenas não seria resultado de um consenso, mas de uma declaração de princípios da versão hegemônica.

Nos anos 1950 o ideário corbusiano já produziria frutos significativos. Além de planos parciais de remodelação e de construções de unidades habitacionais na Europa e nos Estados Unidos, duas cidades novas seriam construídas a partir dos princípios preconizados pela Carta de Atenas: Brasília e Chandigarh. A realização de experiências baseadas nos princípios corbusianos a partir do segundo pós guerra trouxe também a emergência de vertentes críticas a ela, que tomaram corpo na virada dos anos $1950 \mathrm{e}$ 1960, tanto interna quanto externamente aos CIAMs.

No que se refere às críticas externas aos CIAMs, nos Estados Unidos, em plena época de intensa motorização, Kevin Lynch (1997) ${ }^{11}$ e Jane Jacobs (2001) ${ }^{12}$ construíram discursos de reação à ampliação do papel do automóvel nas cidades, tornando-se imediatamente referenciais da revisão do urbanismo modernista. Se a engenharia de transportes priorizava o tráfego em movimento, Lynch e Jacobs olhavam a cidade como pedestres, num movimento claro de reação a uma visão majoritariamente mecanizada dos deslocamentos e da cidade.

Kevin Lynch, posteriormente, faria também incursões sobre os mecanismos de apreensão da cidade a partir do observador em movimento: o condutor de automóvel (APPLEYARD, D.; LYNCH, K. MYER, J., 1963). Nesta ocasião dedicou-se a entender e buscar configurações mais adequadas aos artefatos da engenharia de transportes, como as highways.

Jane Jacobs apresentava uma visão bem mais crítica que a de Lynch. Para a autora, a ênfase nos problemas de tráfego era menos uma causa e mais uma conseqüência de um sistema de planejamento incompetente (JACOBS, 2001). A autora ganharia notoriedade também

11 "A imagem da cidade" teve sua primeira edição em 1960

12 "Morte e vida nas grandes cidades" teve sua primeira edição em 1961. 
pelo enfrentamento público com a poderosa figura de Robert Moses, coordenador do programa de construção de vias expressas da cidade de Nova Iorque neste período.

Colin Buchanan parece ter acompanhado atentamente a situação norte-americana, o que nos leva a crer que conhecia os livros de Lynch e Jacobs. Embora não haja menções explícitas a estas obras, o discurso do engenheiro-urbanista britânico parece apresentar elementos de proximidade com os dos colegas norte-americanos. A valorização da escala do bairro e da rua eram certamente dois deles.

Do outro lado do oceano, no Reino Unido, outro autor trilharia a linha discursiva paralela a de Lynch e Jacobs. Gordon Cullen, em um caminho próximo ao de Camilo Sitte, se empenhava em compreender a estrutura organizativa da escala local a partir da experiência sensorial dos cidadãos com as formas dos lugares urbanos. Seu livro "A paisagem urbana", publicado em 1961, traz uma série de conceitos sobre a escala de projeto urbano, seus materiais e configurações formais ${ }^{13}$. Abordava, entre outras questões, considerações referentes ao impacto do automóvel no desenho da cidade.

Enquanto autores como Lynch, Jacobs e Cullen, entre outros, empreendiam um esforço de desmonte dos preceitos do Movimento Moderno, um grupo interno ao CIAM's procuraria traçar um discurso mais revisionista do ideário da Carta da Atenas do que propriamente de contraposição. A obra de Colin Buchanan nos dá indícios de um grande interesse pelas discussões de revisão dos preceitos do Movimento Moderno, como demonstra suas citações ao plano para a área central de Filadélfia, de Louis Kahn.

$\mathrm{Na}$ Europa, os arquitetos agrupados em torno da denominação Team X desempenharam papel importante neste sentido. O Team X foi formado em 1956 para a $10^{\circ}$ edição do CIAM, realizada em Dubrovnik. Segundo Barone (2002), o principal objetivo do grupo era questionar a validade incondicional dos princípios universais propostos

13 Gordon Cullen pública seu livro em 1961, mas antes já o havia divulgado em partes na revista The Architectural Re- 
pela Carta de Atenas. A autora chama atenção para a emergência da idéia de valores comunitários:

“(...) a partir da noção de que o homem se organiza em comunidades, que desenvolve a necessidade de se diferenciar, se identificar com o local onde habita, criar vínculos sociais e apreender o espaço a partir de seus próprios valores culturais". (BARONE, 2002: 59)

Novamente, Colin Buchanan não parece ter passado ao largo destas preocupações. Sua insistência na definição de limites para a presença do automóvel na cidade reconhecia a pré-existência de relações humanas que seriam sensíveis à convivência com grandes volumes de tráfego. Estas preocupações estiveram, por exemplo, presentes no conceito de environmental areas, elaborado por ocasião do relatório Traffic in Towns ${ }^{14}$.

$\mathrm{Na}$ Inglaterra, em particular, o casal Alison e Peter Smithson teve papel de destaque no Team X e se tornou referência importante para o debate urbanístico britânico dos anos 1950 e 1960. Como questão central, os Smithson's expressavam a insatisfação de sua geração, ou pelo menos de parte dela, com o ideário tanto do urbanismo do Movimento da Cidade Jardim, quanto do Movimento Racionalista (VIDOTTO, 1997).

No entanto, não se tratava de um rompimento com a tradição racionalista, mas de uma atitude revisionista do ideário da Carta de Atenas. Se, por um lado, a dimensão de "comunidade" era um ponto de discordância; por outro, o papel das infra-estruturas, em especial da função de circulação (uma das quatro funções da cidade na Carta de Atenas), permaneceria merecedora de uma posição de destaque.

Na obra do Casal Smithson a função "circular" assumiria um significado ampliado. As vias estruturais teriam o papel de elemento que retomaria a identidade perdida nas grandes cidades. Neste sentido, Peter Smithson chama atenção para o seguinte aspecto:

"Mobility has become the characteristic of our period. Social and physical mobility, the

14 Explicaremos este conceito mais adiante no capítulo 5. 
feeling of a certain sort of freedom, is one of the things that keep our society together, and the symbol of this freedom is the individually-owned motor car. (...) The roads (together with the main power lines and drains) form the essential physical infra-structure of the community. The most important thing about roads is that they are physically big, and have the same power as any big topographical feature, such as a hill or a river, to create geographical, and in consequence social, divisions." (SMITHSON, 1968: 51)

A defesa deste conceito amplo de mobilidade e suas implicações não deixava de ser bastante útil ao discurso que Buchanan vinha empreendendo desde meados da década de 1950, sistematizado pela primeira vez em Mixed Blessing. Em particular, a questão do automóvel como símbolo de liberdade individual se enquadrava com perfeição naquilo que o engenheiro-urbanista britânico vinha construindo como discurso.

O projeto do Casal Smithson para o concurso de Berlin em 1957 seria uma grande referência formal para o urbanismo britânico e, ao que tudo indica, também para Colin Buchanan, como detalharemos no capítulo 5 e 6 . Um sistema viário elevado para pedestres foi previsto para ocupar toda a área central da cidade, resolvendo o indigesto conflito com os automóveis.

A influência do Casal Smithson na obra de Colin Buchanan se torna ainda mais instigante na medida em que há uma forte relação do discurso dos arquitetos ingleses com a tradição racionalista de urbanismo e arquitetura. Nitschke (1966) faz uma interessante análise em que assume uma linha evolutiva, que parte de Le Corbusier, passa por Louis Kahn e chega finalmente ao Team X e aos Metabollistas japoneses.

De fato, a obra de Kahn teve grande repercussão na Grã Bretanha. O plano que este arquiteto desenvolveu para uma intervenção no centro da cidade de Filadélfia, no Estado da Pensilvânia, ao longo dos anos 1950, foi enfaticamente mencionado pelo Casal Smithson (SMITHSON, 1968) e figurou na literatura de urbanismo ao longo dos anos 1950 e 1960, como por exemplo no clássico “Town Design” de Frederick Gibberd (1962). 
Trata-se, acreditamos, de um plano que reeditou a questão da circulação a partir de Le Corbusier, propondo a articulação das questões de planejamento urbano e transportes. Sua notável abordagem dos problemas do tráfego urbano foi certamente incorporada e assimilada por Buchanan, que sintomaticamente o citou em Traffic in Towns e Mixed Blessing.

No plano para a reorganização da área central de Filadélfia, Kahn propôs vias especificamente destinadas ao tráfego ("go streets") e vias vocacionadas para o tráfego de pedestres, estacionamentos e transporte coletivo ("stop streets"). A estas estariam associadas quatro vias expressas, que contornariam a área central da cidade, sendo responsáveis pelos deslocamentos de caráter urbano. Este sistema de vias abasteceriam um eixo de pedestres, na parte mais importante da área central da cidade.

As chamadas go streets seriam implantadas a partir do conjunto de vias existentes, num sistema binário de sentidos de circulação. Já as stop streets seriam como vias de serviço, concentrando as "impedâncias" ao tráfego motorizado. Também era neste tipo de via que circularia o transporte coletivo, sobre trilhos ou pneus.

Havia, portanto, uma nova proposta de hierarquia de vias, que partia da menor restrição aos movimentos dos automóveis, nas vias expressas, até chegar em sua total proibição, nas vias de pedestres. Neste caminho, estava presente uma noção muito clara do sentido da circulação urbana motorizada, onde todos os tipos de movimentos e suas demandas eram contemplados, num verdadeiro sistema de circulação. Formalmente, chama atenção a gradativa restrição ao movimento motorizado, das áreas mais externas para as mais centrais.

Este sistema viário articulava-se às funções urbanas da área central. Não por acaso, na região onde havia maior concentração comercial e institucional, Kahn previa um eixo pedestrianizado. De fato, todo o sistema de circulação convergia para a área central. Para ele, "center city is a place to go - not to go through" (MORRIS, 1966: 34). 

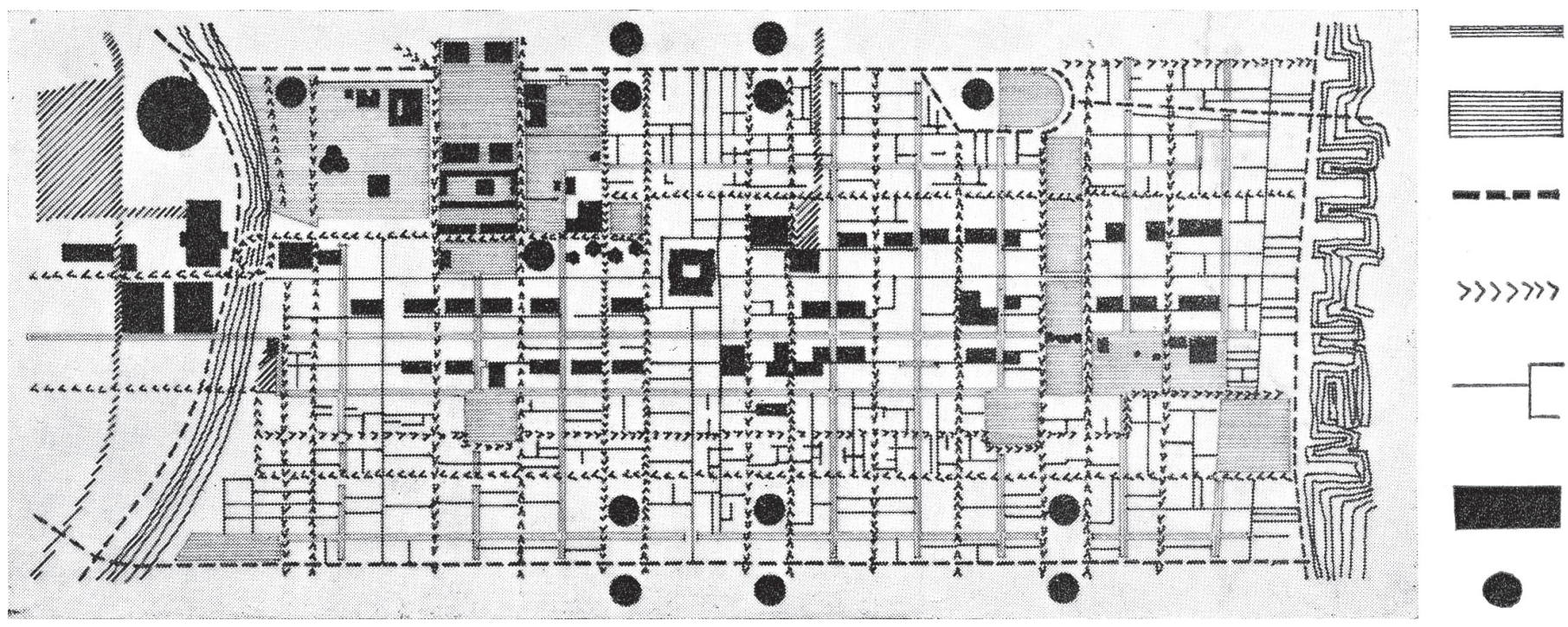

pedestrian ways

squares, parks and malls

\section{expressways}

'go' streets - through motor traffic; no parking; no trolley cars or local buses

Figura 3: Plano para Filadélfia, Louis Kahn - 1953-1956. Estudo de circulação Fonte: MORRIS, 1966: 33

Por isso, este conjunto de diferentes tipos de vias estaria associado a um sistema de edifícios-garagens, públicos e privados. Os primeiros estariam situados ao longo do eixo principal de pedestres, enquanto os estacionamentos privados se implantariam prioritariamente ao longo das vias expressas.

Louis Kahn já no início dos anos 1950 associava circulação e estacionamento, como elementos inseparáveis de um mesmo sistema. Ao mesmo tempo, comparava a hierarquia das vias a um sistema de navegação composto por rios, baías, canais e as docas, como sendo os estacionamentos.

Este entendimento da circulação como um fenômeno mais abrangente e não restrito ao movimento dos automóveis, estaria bastante presente no discurso de Colin Buchanan, não só pela formulação de uma hierarquia viária associada às atividades urbanas, como proposta em Traffic in Towns, mas também pela estreita relação entre as demandas de 
movimento e de parada que se apresentavam no tráfego motorizado.

Todo este raciocínio formulado por Louis Kahn estava ancorado na sua crítica à forma de tratamento dos sistemas de circulação urbanos:

"There is no order to the movement on streets as the moment. Streets look alike, reflecting little of the activities they serve (...). The design of the streets is design for movement". (NITSCHKE, 1966: 168-169)

De fato, ao relacionar a arquitetura com o tipo de movimento, o plano de Kahn para a Filadélfia parecia encaminhar-se para algo que poderia ser chamado de "arquitetura do movimento". Esta preocupação se estenderia até a escala do edifício. Na escala da cidade, esta questão se apresentava por meio dos edifícios-garagem, concebidos como referenciais arquitetônicos na paisagem urbana.

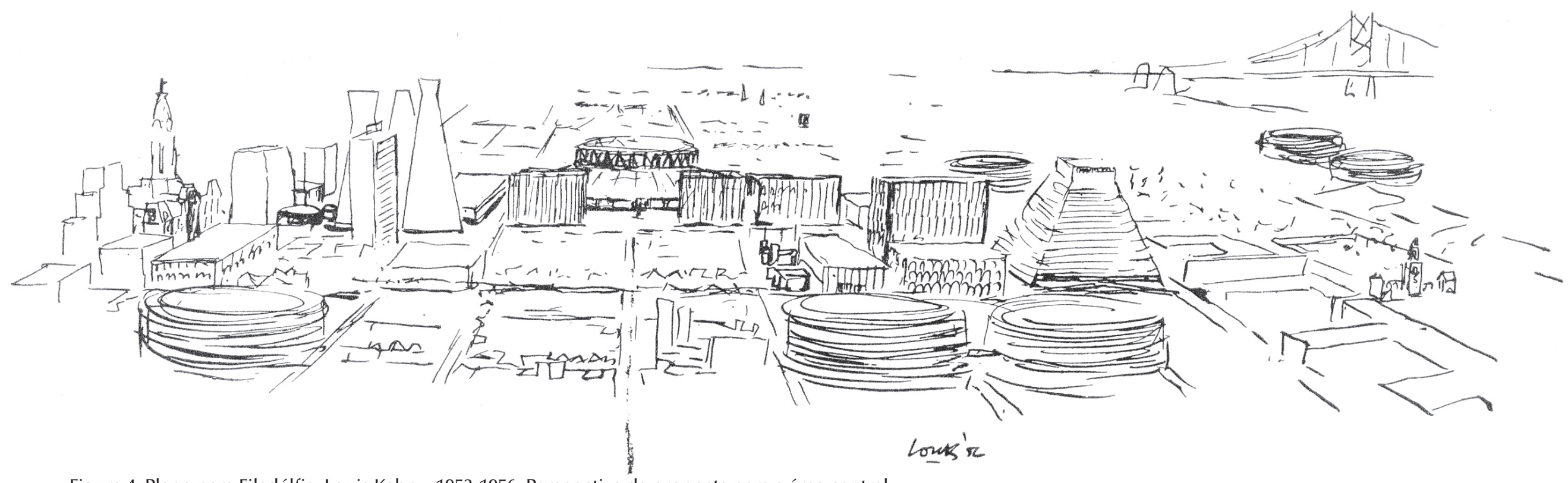

Figura 4: Plano para Filadélfia, Louis Kahn - 1953-1956. Perspectiva da proposta para a área central Fonte: MORRIS, 1966: 33 
No desdobramento dos estudos para a cidade de Filadélfia ao final dos anos 1950, Kahn experimentaria ainda mais as potencialidades da circulação na escala dos edifícios. No projeto para East Market, níveis urbanos diferentes articulavam a circulação de pedestres, automóveis e transporte público com as atividades urbanas, naquilo que

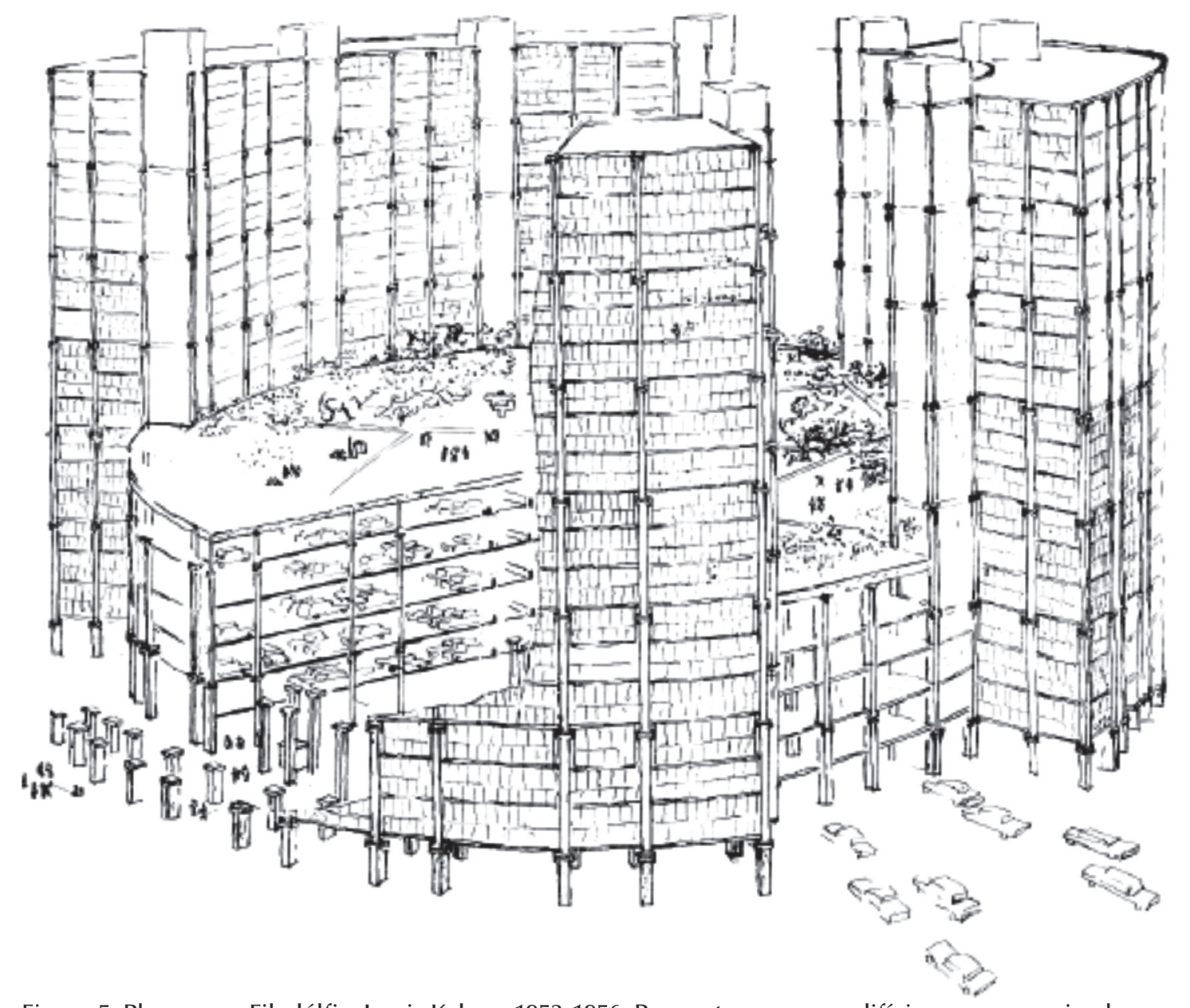

Figura 5: Plano para Filadélfia, Louis Kahn - 1953-1956. Proposta para um edifício-garagem privado Fonte: JELICOE, 1961: 132 


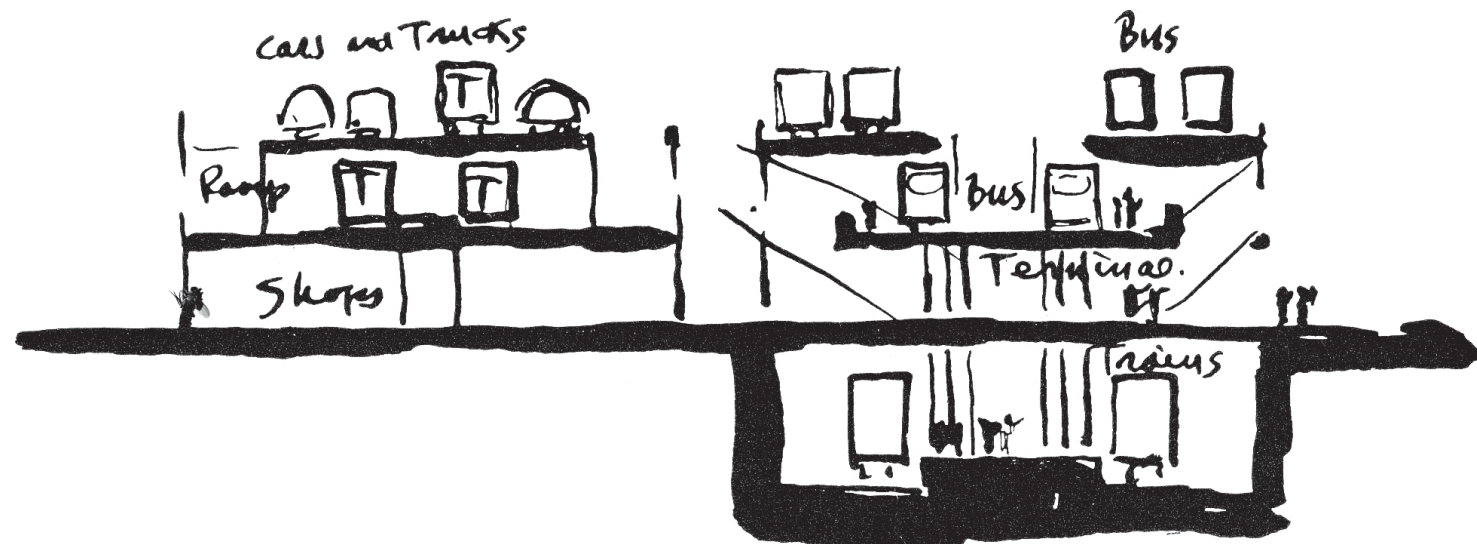

Figura 6: Plano para Filadélfia, Louis Kahn - 1953-1956. Croqui para área do Mercado Leste Fonte: MORRIS, 1966: 34

o arquiteto chamaria de "Viaduct Architecture".

Louis Kahn, neste plano, retrabalhava os conceitos difundidos por Le Corbusier, não só por meio da Carta de Atenas, mas também por meio de seus "projetos-tese", como a Vila Radiosa, ou mesmo de suas realizações como o plano para a nova cidade de Chandigarh (1951).

Neste sentido, os conceitos de Kahn estão bastante próximos daqueles empregados por Corbusier na definição da hierarquia viária em Chandigarh, onde os diferentes tipos de movimento e suas velocidades geram sete classes de vias. Ao mesmo tempo, Kahn empresta de Corbusier a mesma preocupação com a dimensão formal da infra-estrutura de transportes.

No entanto, o que mais se destaca como desdobramento nos anos 1960 e, particularmente na obra de Buchanan, é a forma de resolução dos conflitos de tráfego por meio de planos urbanos diferentes. Corbusier já no início dos anos 1930 anunciava os "decks" 
para pedestres como solução para a compatibilização dos movimentos motorizados e não motorizados, nas áreas mais densamente povoadas.

Paralelamente, outros desdobramentos dos conceitos Corbusianos se apresentavam nos anos 1960, com caráter mais investigativo do que propriamente como soluções aplicáveis na prática profissional. Curiosamente, embora despertassem grande interesse na época, tais exemplos estiveram ausentes das referências formais da obras de Colin Buchanan.

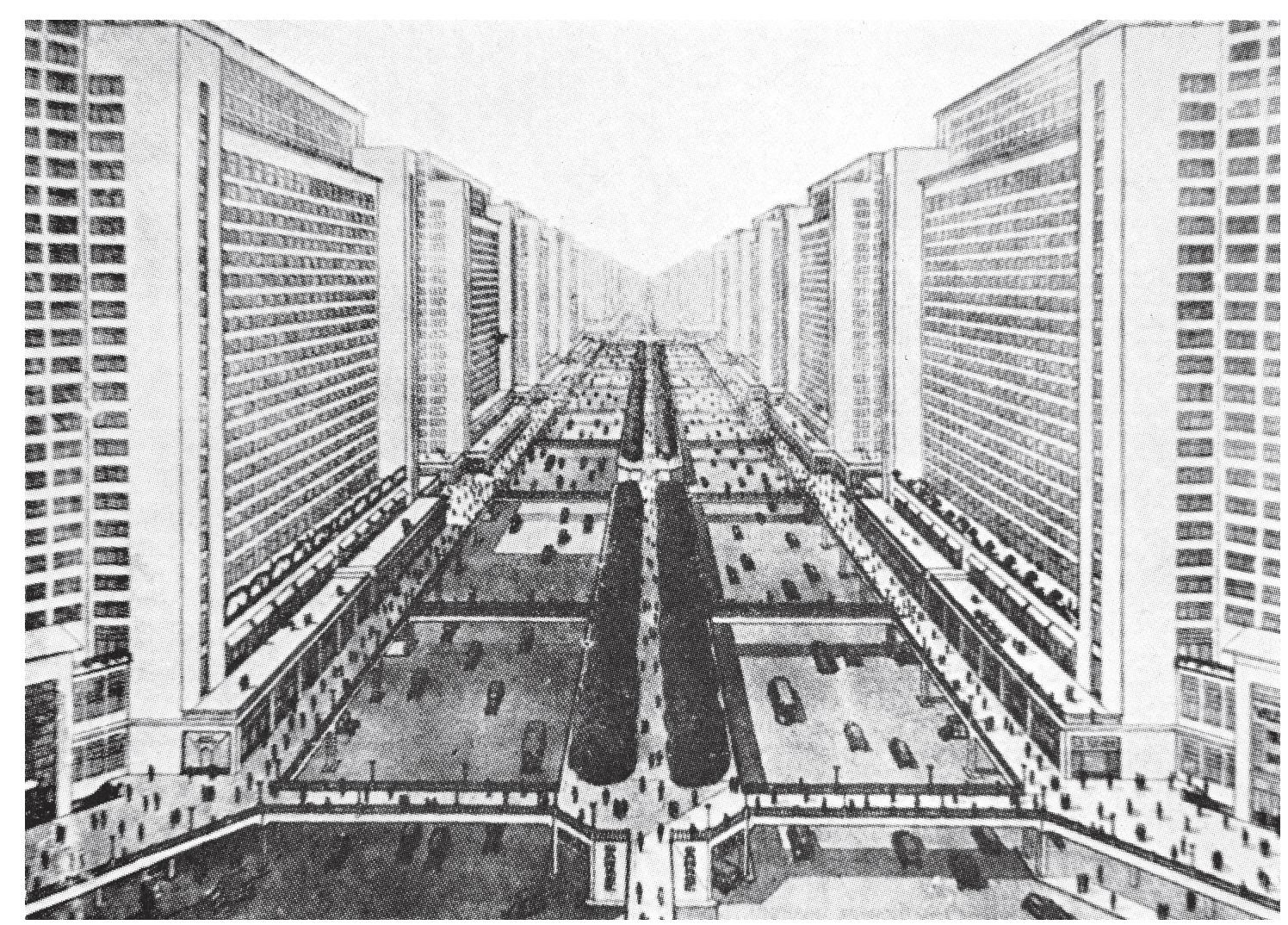

Figura 7: Vila Radiosa, Le Corbusier - 1933 Fonte: RICHARDS, 1968: 108 
Conforme Benévolo,

“(...) a teoria arquitetônica deste período prolonga deliberadamente o seu empenho para além das ocasiões concretas, produzindo uma série de modelos que se antecipam à realidade para assim aproveitar as consequências qualitativas da maior dimensão e da maior velocidade de crescimento" (BENÉVOLO, 2009a: 81)

O grupo de arquitetos japoneses, conhecidos como Metabolistas, se notabilizou por seus projetos utópicos de infra-estruturas, “desenvolvidos em três dimensões e portanto legíveis como imagens arquitetônicas em grande escala” (BENEVOLO, 2009a: 81). Entre eles, destaca-se o projeto utópico para uma Cidade Helicoidal, de Kisho Kurokawa, onde o sistema de circulação seria composto por vias elevadas e espirais de acesso ao solo. A imagem futurista proposta não abre mão do transporte individual.

Outro ensaio típico destes anos é o plano de G. A. Jelicoe para uma cidade ideal, chamada Motopia. Jellicoe buscava pensar uma cidade após a plena difusão do automóvel, particularmente assumindo o fenômeno de um carro por família ou mesmo por habitante. Para isto, o autor concebia uma superestrutura única de 1,6 km de malha viária, onde as vias ocupavam a cobertura e os estacionamentos se situavam no pavimento logo abaixo, sendo inspirados nos shoppings centers norte-americanos. Por trás desta solução formal de cidade, estava a intenção de separação do homem mecânico do homem biológico (JELLICOE, 1961). Neste sentido, Jelicoe retomava a visão de cidade e circulação conforme Le Corbusier.

No âmbito da prática profissional, o programa de construção de novas cidades no Reino Unido, conhecido como New Towns, representava um momento de convergência dos debates e das investigações urbanísticas do segundo pós-guerra. Colin Buchanan foi contemporâneo das New Towns inglesas e acompanhou o vigoroso debate urbanístico que se processava dentro e fora do Reino Unido, a partir deste imenso esforço nacional de planejamento e construção de cidades. Tanto em Mixed Blessing

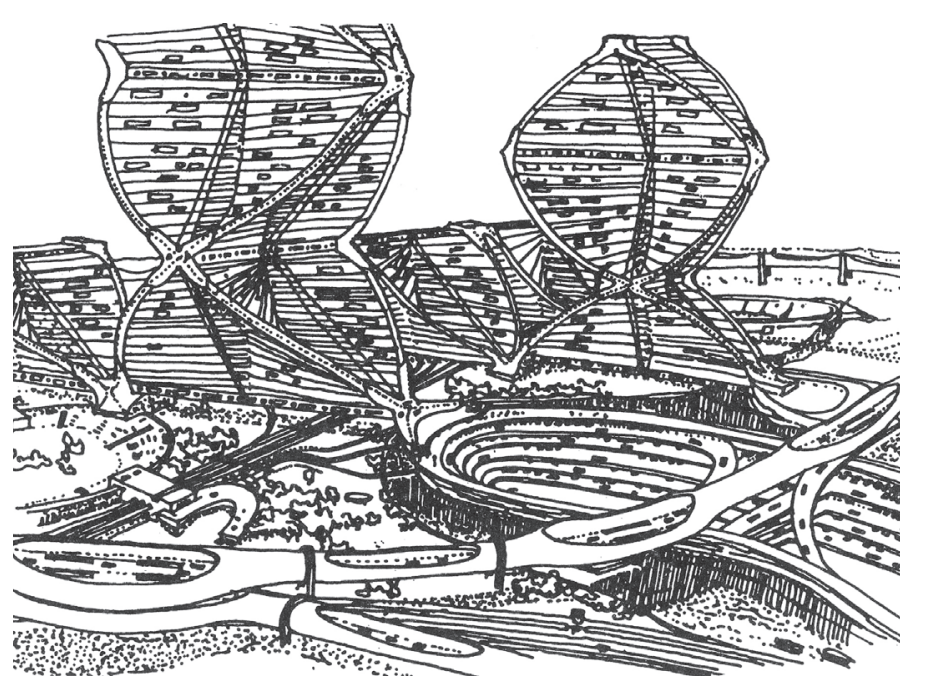

Figura 8: Cidade Helicoidal, K. Kurokawa -1961 Fonte: BENEVOLO, 2009: 82 
quanto em Traffic in Towns o engenheiro-urbanista dedicou espaço para considerações a respeito destas experiências, ora ressaltando pontos positivos, ora negativos, como detalharemos mais a frente.

Tratava-se de uma oportunidade histórica: beneficiar-se da experiência do planejamento e da construção de 32 cidades ao longo de aproximadamente 25 anos. Neste cenário, o Reino Unido foi palco da montagem de um amplo e poderoso sistema de planejamento urbano e regional.

A subida ao poder do partido Trabalhista no segundo pós guerra representou a emergência da social-democracia e, entre 1945 e 1951, o governo deste partido estabeleceu uma nova agenda política baseada na expansão das responsabilidades do Estado, com maior interferência no gerenciamento da economia (TAYLOR, 2008). Tratou-se da montagem de um Estado convertido em principal agente da promoção do desenvol-
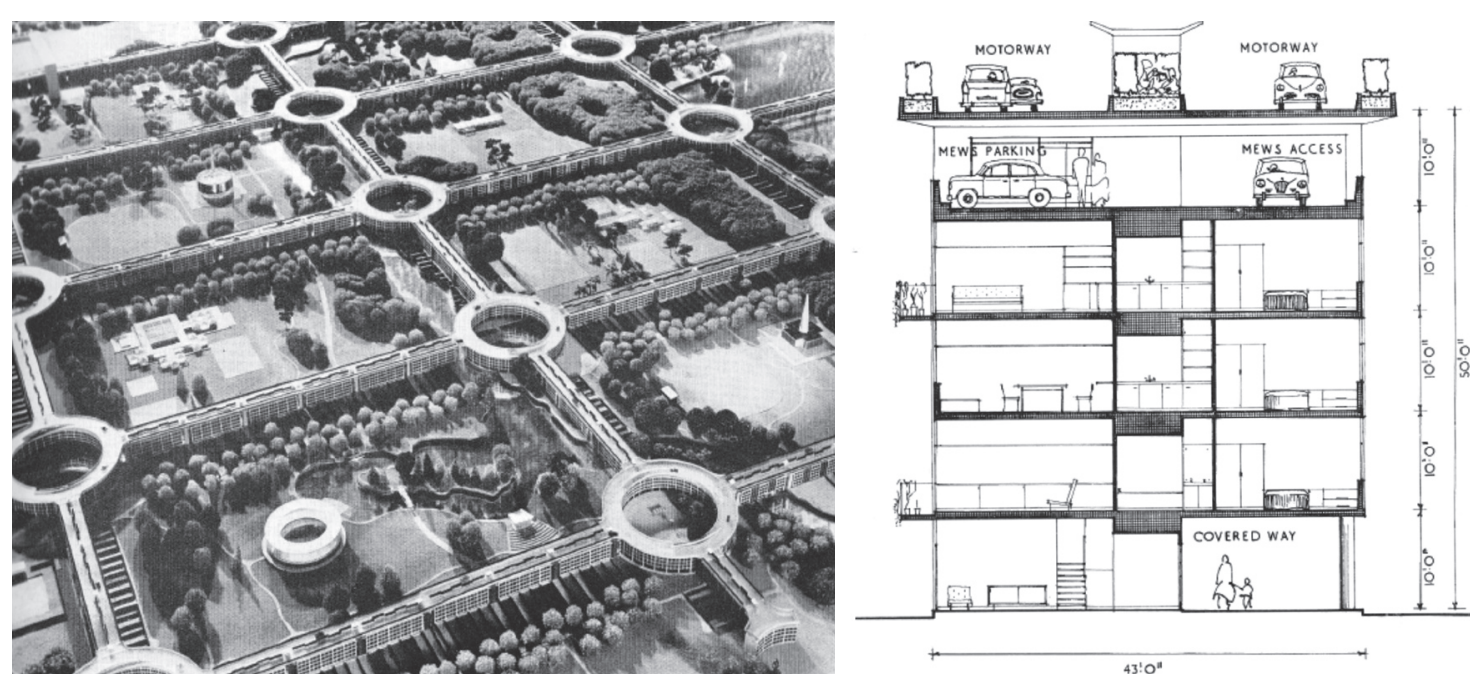

Figura 9: Motopia, G. A. Jelicoe - 1961

Fonte: JELICOE, 1961: 145 e 150 
vimento do país ${ }^{15}$. Autores como Peter Hall (2002), Nigel Taylor (2008), Barry Cullingworth \& Vincent Nadin (2007), entre muitos outros, deram contornos mais precisos à formação da "máquina britânica de planejamento", conforme Hall (2002). Segundo Leonardo Benévolo, com as New Towns criou-se uma

“(...) espiral do método experimental - hipótese, experiência, verificação - [que] havia iniciado o seu movimento há já uma geração, vindo confirmar com a evidência dos seus efeitos a tese da cientificidade da arquitetura moderna, um dos princípios que se afirmaram entre as duas guerras". (BENÉVOLO, 2009a: 53)

De fato, este grande esforço de construção de cidades, como não poderia deixar de ser, constituiu-se também em um ponto de convergência do debate urbanístico do segundo pós-guerra. O urbanismo modernista da Carta de Atenas, sua revisão pelo Team X e seu desmonte por Lynch, Jacobs e Cullen estiveram fatalmente presentes ao longo das duas décadas e meia desta experiência.

Na primeira geração de New Towns (Mark I) foram planejadas 14 cidades, entre 1946 e 1950. Em todas elas, ressalta-se a influencia do Movimento Cidade Jardim e de seus desdobramentos norte-americanos, sobretudo o exemplo de Radburn. Esta importante referência recebeu a chancela do governo inglês, como demonstram os vários Relatórios Governamentais (como Barlow Report) e também o Plano para Grande Londres de Patrick Abercrombie (POTTER, 1976).

A cidade nova de Harlow, planejada em 1947 por Frederick Gibberd, é um interessante exemplo deste primeiro conjunto de New Towns. Destaca-se a aplicação dos preceitos conceituais do modelo Cidade Jardim e seus elementos, particularmente o princípio da unidade de vizinhança e sua relação com o princípio da separação dos modos sobre pneus em relação aos pedestres. Como ressalta Stephen Potter:

15 Do ponto de vista legal, o planejamento britânico do período após a II Guerra Mundial se ancorou principalmente em cinco Atos do governo: "Distribuction of Industry Act" (1945), "New Towns Act" (1946), "Town and Country Planning Act" (1945), "National Park and Access to the Countryside Act" (1949), "Town Development Act" (1952).

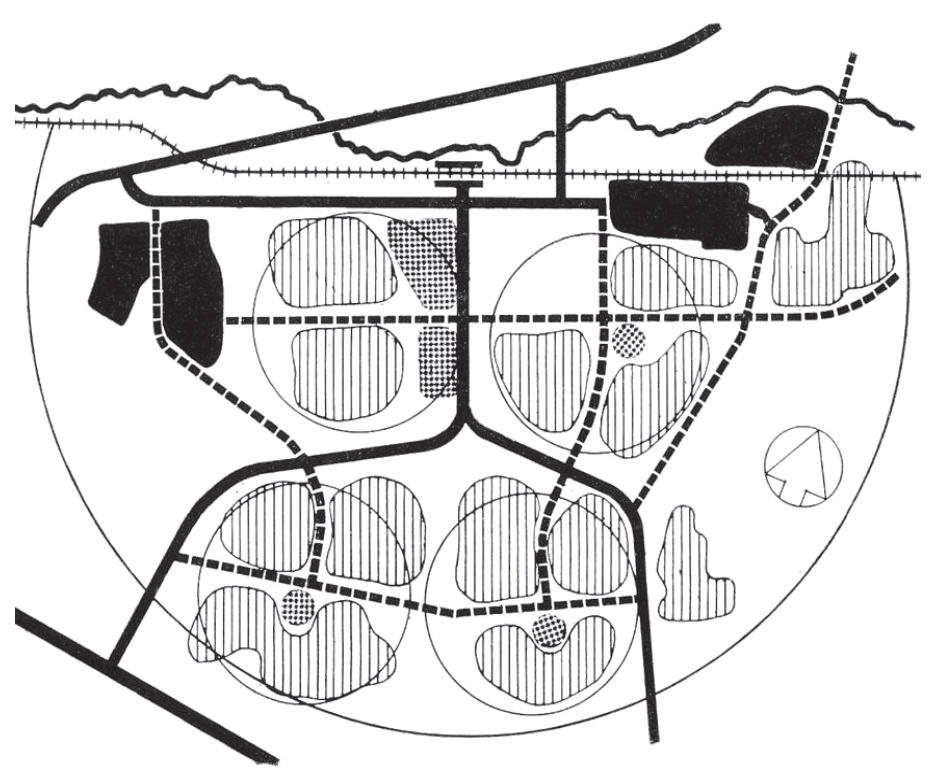

Figura 10: Harlow New Town - Frederick Gibberd -1947 Fonte: GIBBERD, 1962: 41 
"The adoption of the neighborhood into a hierarchical concept was an innovation of primary importance. Most new town plans of this time saw neighborhood and limiting town size as all that was necessary to ensure the pedestrian accessibility". (POTTER, 1976: 82)

O processo de implantação das primeiras New Towns trouxe também um vigoroso movimento de crítica aos seus princípios norteadores; sobretudo em relação a aspectos que Galantay (1977) chamou atenção:

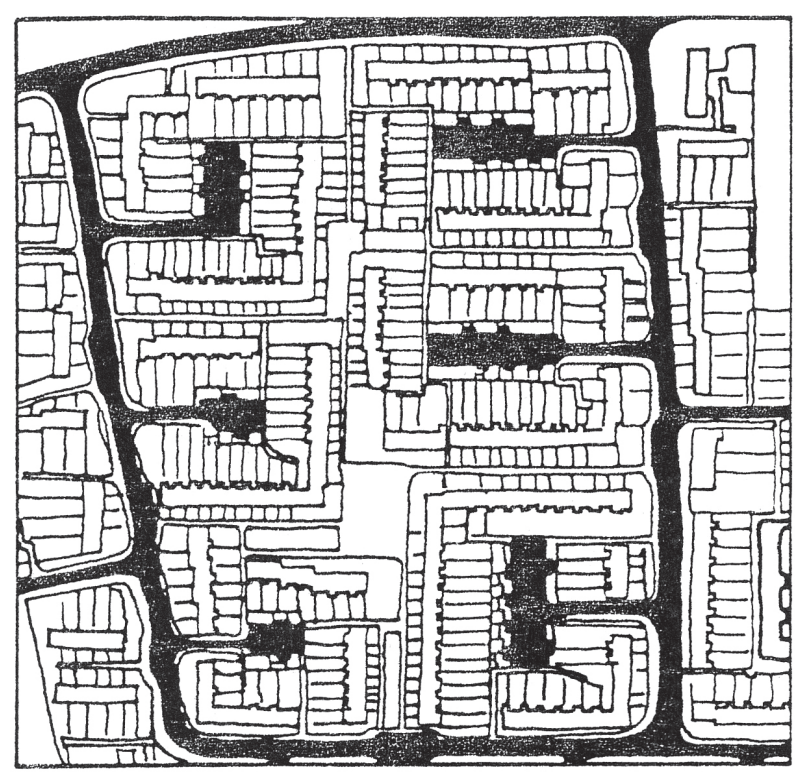

Figura 11: Harlow New Town - Frederick Gibberd -1947 Fonte: MADANI-POUR, 1992

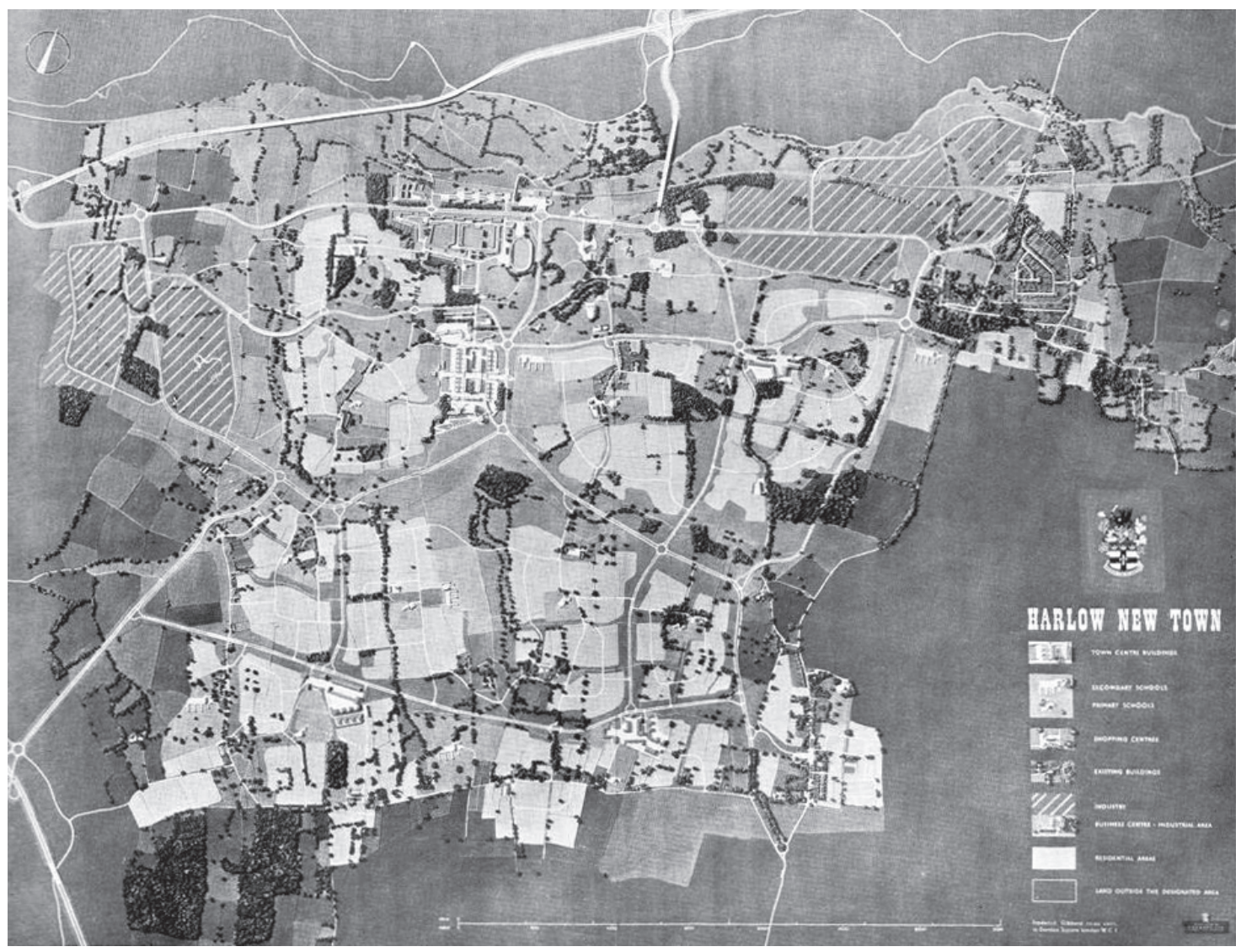

Figura 12: Harlow New Town - Frederick Gibberd -1947 Fonte: GIBBERD, 1962: 41 
"Ciertos defectos de los planes de la primera generación pronto fueron objeto de agudas críticas: las bajas densidades y la generosa provisión de zonas verdes deban lugar a elevados costes de infraestructura. Además se les achacó la falta de variedad visual y animación. La multiplicación de sus centros minaba la vitalidad del centro urbano. El objetivo inicial de población, fijado em 60000 habitantes, resulto demasiado pequeno para sostener uma variedad suficiente de instalaciones culturales y de recreo. Al mismo tiempo, el aumento em el número de coches hizo subir la demanda por aparcamientos y garajes". (GALANTAY, 1977: 94)

Colin Buchanan acompanhou de perto o processo de avaliação desta primeira geração de cidades. Particularmente, o desmonte da noção de unidade de vizinhança parece ter sido bastante assimilado por ele, como veremos no capítulo 5 . Entre seus parceiros de trabalho estiveram urbanistas ligados ao debate e à pratica no contexto das New Towns. Stephen Potter ressalta aspectos importantes desta crítica e seus desdobramentos:

“(...) the influence of sociological neighborhood was waning. By the mid-1950's it had become clear that population groups of 5-10,000 had no particular meaning in terms of 'neighborliness' (i.e. social contacts) and it was only in much smaller groups that location had much to do with this. In addition, the neighborhood concept ignored the development of links based upon organizational contacts (e.g. workplace, school, college, recreation, etc) and indeed, its form positively discouraged them. This gave further weight to the proponents of compact towns, in which personal contacts would nor be hindered by artificial social barriers" (POTTER, 1976: 92)

Na segunda geração de New Towns, a opção por cidades mais compactas apresentou sérios desdobramentos no arranjo físico das cidades e seus sistemas de transportes. Em vez da aplicação do conceito de unidade de vizinhança, que diluía o caráter urbano em assentamentos de baixa densidade, essa nova geração de cidades optava pela afirmação de suas centralidades e pelo amplo acesso ao centro por toda a população.

A famosa, mas não construída, cidade nova de Hook (1957) demonstrava justamente a 


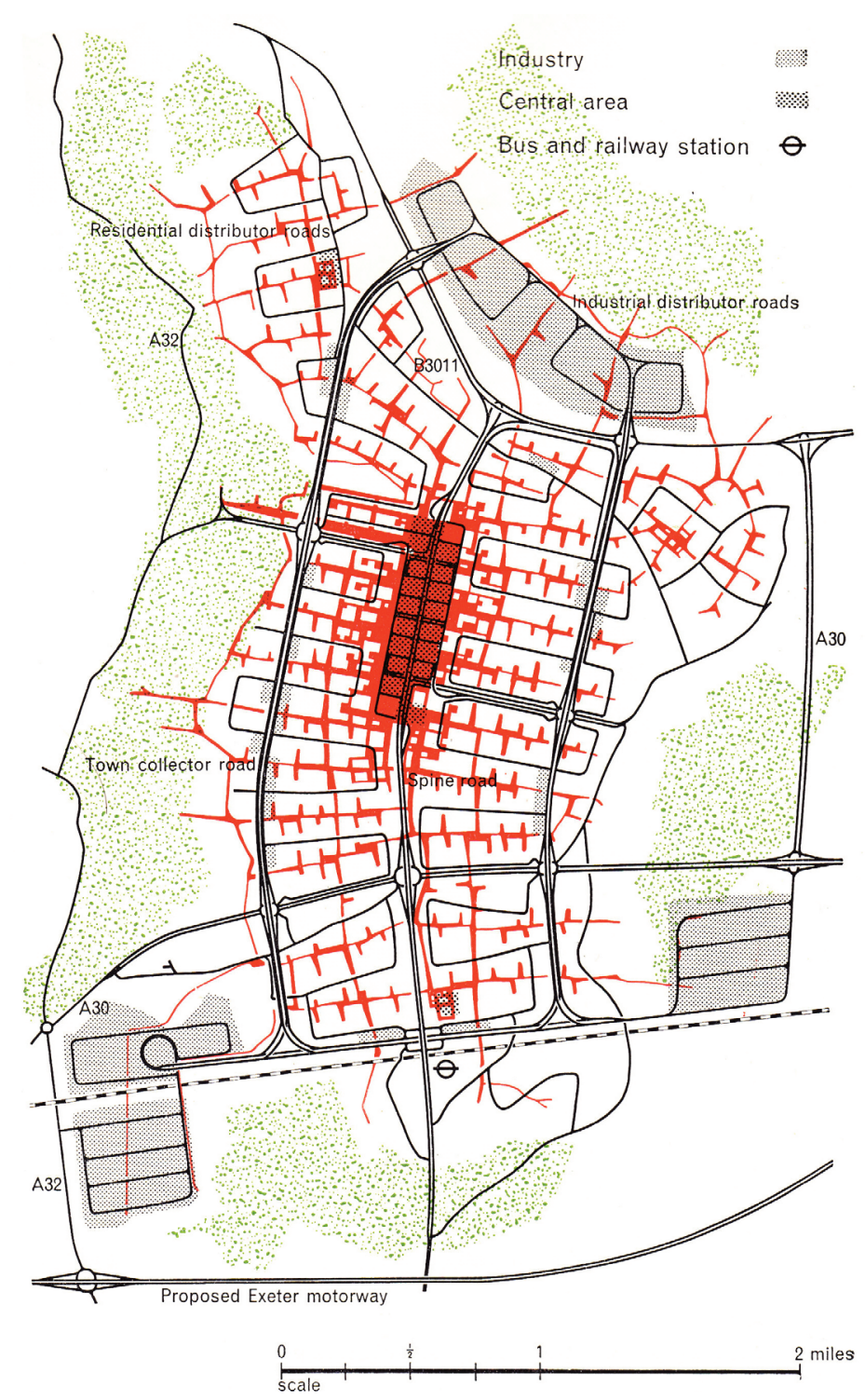

Figura 13: Hook New Town, London County Council - 1957 Fonte: BUCHANAN, 1963: 168 direção oposta aos caminhos trilhados nas New Towns da primeira geração. Não por acaso, Madani-Pour (1992: 19) a denomina ironicamente como "a city in a garden", numa clara alusão à oposição aos conceitos aplicados nas cidades da geração Mark I.

Balizado pelos princípios de "urbanidade", "deslocamentos motorizados", "cidade e campo" e "balanço populacional" (MADANI-POUR, 1992) o plano para Hook procurava promover um intenso adensamento das áreas urbanizadas para permitir a menor distância possível ao centro, deixando clara a oposição entre cidade e campo. O plano também previa densidades populacionais de $160 \mathrm{hab} / \mathrm{ha}$ para as áreas residenciais, resultando numa densidade média de 87 hab/ha (POTTER, 1976), sendo estas sensivelmente maiores que as cidades da geração Mark I.

Neste sentido, tratava-se de uma idéia bastante contraditória: ao mesmo tempo em que previa uma densa rede conectada ao centro destinada aos pedestres, admitia também uma taxa de motorização de 1,5 automóveis por família, compatível com índices observados no estado norte-americano da Califórnia naquele momento.

De fato, o plano para Hook traduziu uma mudança nas diretrizes gerais para as New Towns neste período, no que diz respeito aos automóveis. Potter (1976) destaca que nos anos 1950 o aumento da demanda de estacionamentos se colocava como um ponto importante para o planejamento. Na primeira geração, a diretriz inicial governamental para esta questão previa uma relação de 1:12 (garagens:imóveis) e em 1959 esta relação já era de 1:4,1.

A área central estaria prevenida dos problemas observados nas cidades existentes por meio de um complexo sistema arquitetônico, que previa a associação dos usos do solo, sistemas de circulação e estacionamento em vários níveis, segregando pedestres e veículos; numa clara aproximação com as propostas de Louis Kahn para Filadélfia. Esta associação se revelava no caráter linear da área central de Hook, organizada a partir do sistema viário estrutural. 

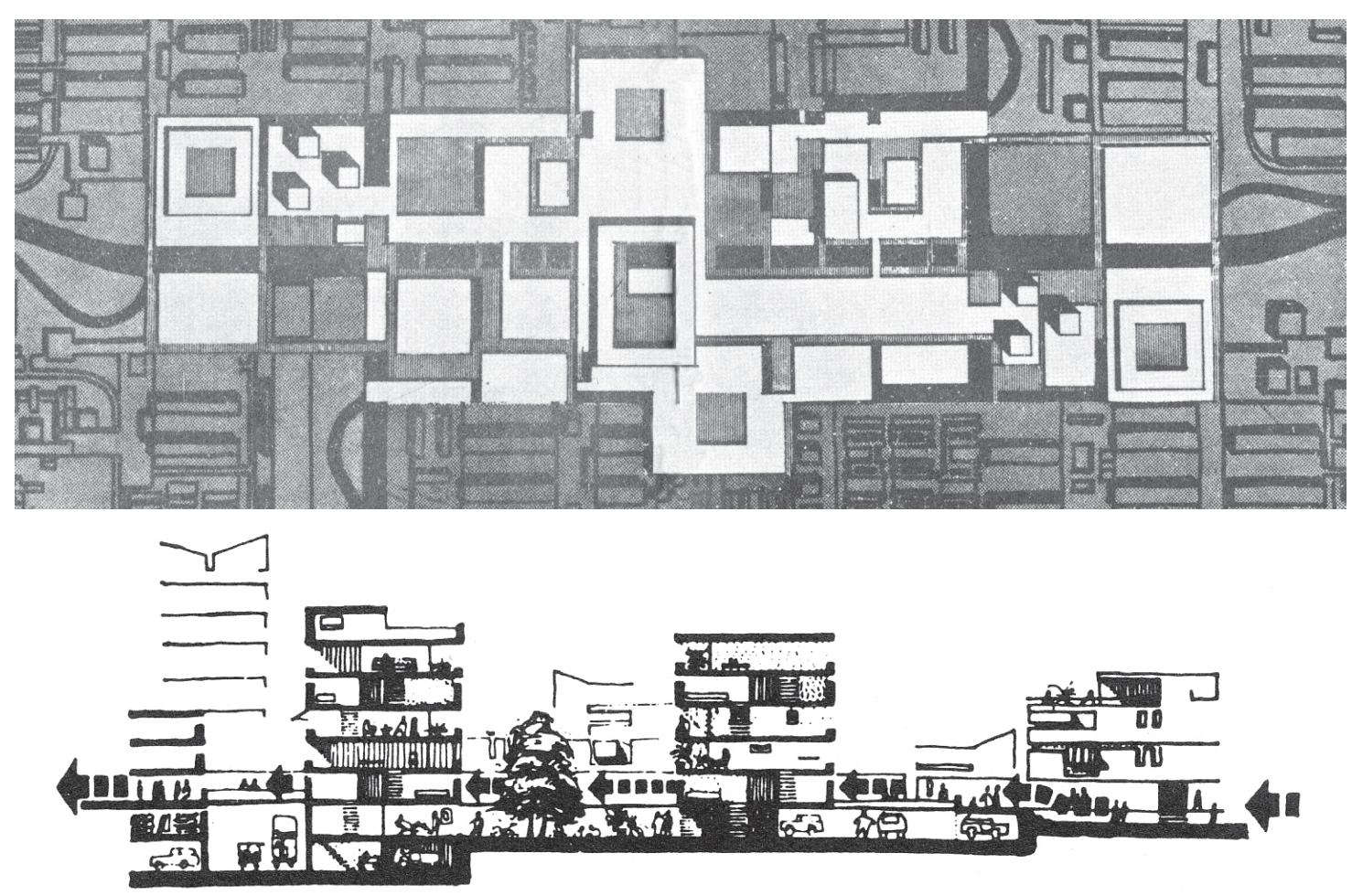

Figura 14: Hook New Town, London County Council - 1957: area central Fonte: BENEVOLO; MELOGRANI; LONGO, 1977: 230-232

Colin Buchanan incluiu comentários entusiasmados ao plano para Hook no relatório Traffic in Towns: "(...) high environmental standards, with great convenience and pleasantness of scene for pedestrians, were decided upon as initial objectives". Mas, ao mesmo tempo, advertia: "consequently, in order to secure a high level of accessibility, complex architectural and engineering forms are required at high cost" (BUCHANAN, 1963: 168).

Para Buchanan, ao que parece, o plano para Hook apresentava uma abordagem amplamente baseada nas considerações sobre a circulação na cidade e na esfera do projeto urbano como solução para os conflitos entre modos diferentes. Consolidava também 
sua crítica ao modelo radio-concêntrico, como forma de resolução dos problemas de tráfego nas áreas centrais, desenvolvida desde Mixed Blessing.

Banhan (1978: 74) comentando o relatório Traffic in Towns, reforça a sua associação aos conceitos desenvolvidos por ocasião do plano para Hook e, de forma particular, um certo "caráter visionário" da arquitetura inglesa neste período. Além disso, o arquiteto Geoffrey Crow, membro da equipe de Traffic in Towns, havia trabalhado em outra New Town do mesmo período, que partilhava dos mesmo princípios norteadores de Hook: Cumbernauld, na Escócia.

A terceira e última geração de cidades novas Britânicas coincidiu com uma inserção profissional mais ativa de Colin Buchanan, já como figura reconhecida no âmbito das discussões sobre os transportes e planejamento urbano. Seus trabalhos não passaram despercebidos aos planos desta geração de New Towns, seja como referência ou como contraposição.

Madani-Pour, comentando os planos desta geração, destaca:

"High levels of car ownership, due to increasing national wealth in the 1960's, together with a rise in the proposed population of new towns, played a decisive role in urban forms. Solving the side effects of car seems to have been the major task of the designers: highway networks; hierarchy of roads; superblocks; segregation of movement; traffic generator land uses; and emphasis on public transport as opposed to private car whose dominant role is recognized" (MADANI-POUR, 1992: 21)

A questão do aumento da frota de automóveis e, como conseqüência, o acirramento das discussões em torno dos seus efeitos adversos passaram a dominar os debates. Neste momento já era bastante conhecida a visão de Buchanan, buscando acomodar os automóveis nas cidades existentes.

Por outro lado, neste período também passou a se afirmar a busca por outras opções modais. Neste sentido, a contraposição entre os planos Runcorn (1967) e Milton Keynes 


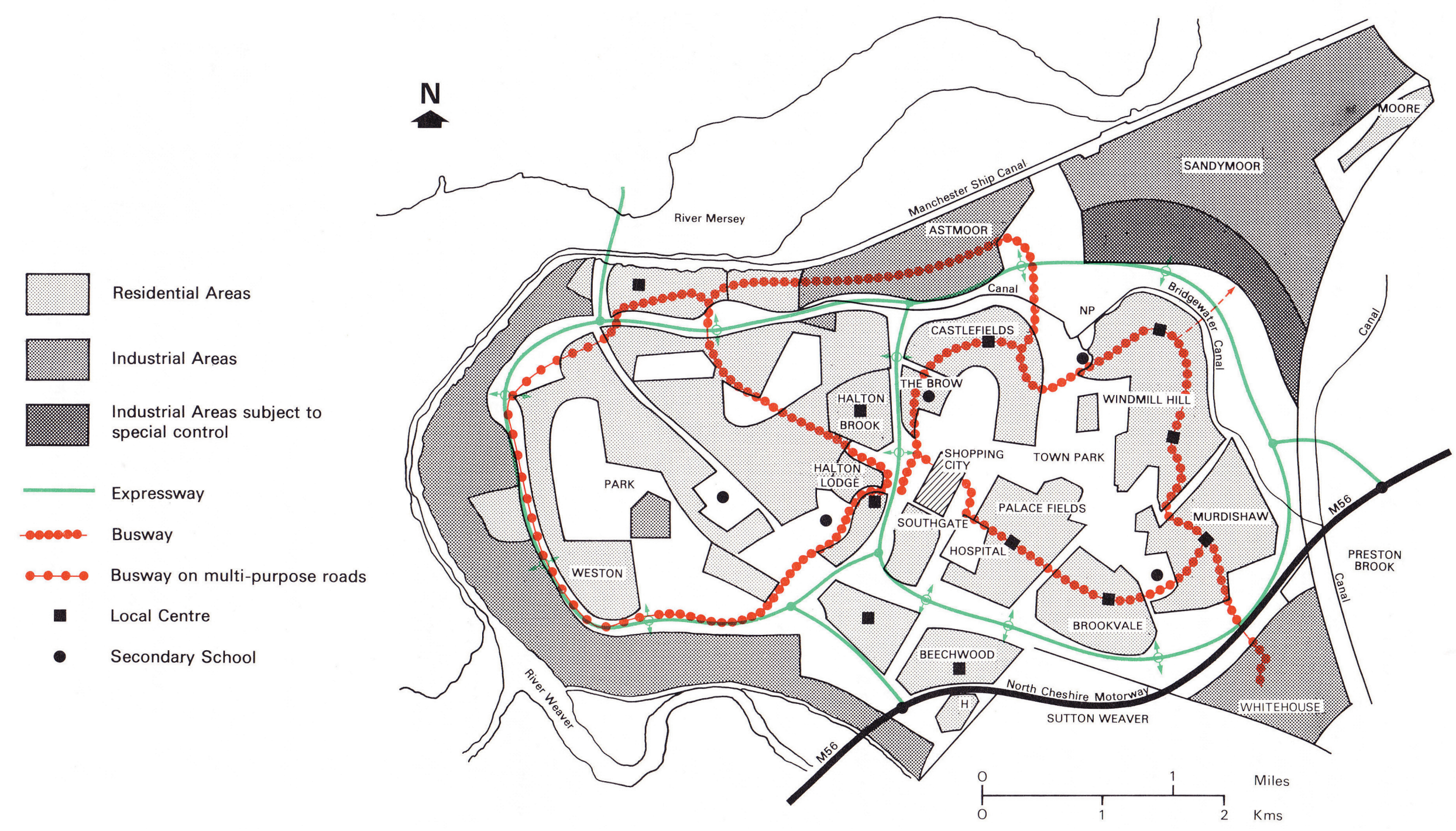

Figura 15: Plano para Runcorn, Arthur Ling and Associates - 1967: vias exclusivas para ônibus e vias expressas Fonte: IHT, 1987: 226 


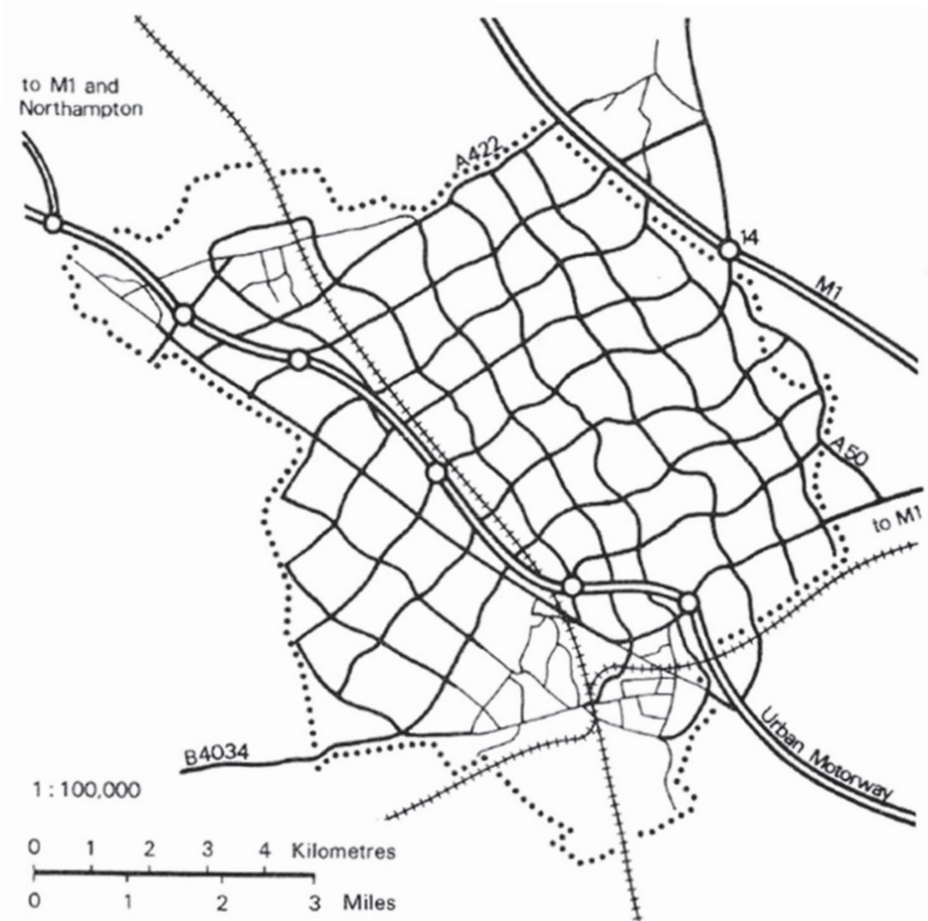

Figura 16: Plano Para Milton Keynes, Llewelyn-Davies Weeks Foresder-Walker \& Bor - 1970: Sistema viário estrutural Fonte: MILTON KEYNES DEVELOP CORPORATION, 1970

(1970) nos fornece um panorama interessante deste momento. Em Runcorn, o plano se baseou na distinção entre o sistema viário para modos públicos e privados. Ao primeiro se associavam os centros locais de atividades, as unidades escolares e as maiores densidades habitacionais. Foi, além disso, possivelmente uma das primeiras experiências concretas de corredores exclusivos para ônibus. O sistema viário estrutural para automóveis foi previsto afastado dos núcleos de moradia e comércio, na periferia dos assentamentos. No entanto, mantinha acesso ao centro principal e foi previsto ainda um sistema de estacionamentos.

Já em Milton Keynes apostou-se na predominância do automóvel como modo de deslocamento. Neste sentido, foi adotada a grelha como forma de resolver melhor as demandas colocadas pelos modos privados. Os princípios que ordenaram o plano não dei-

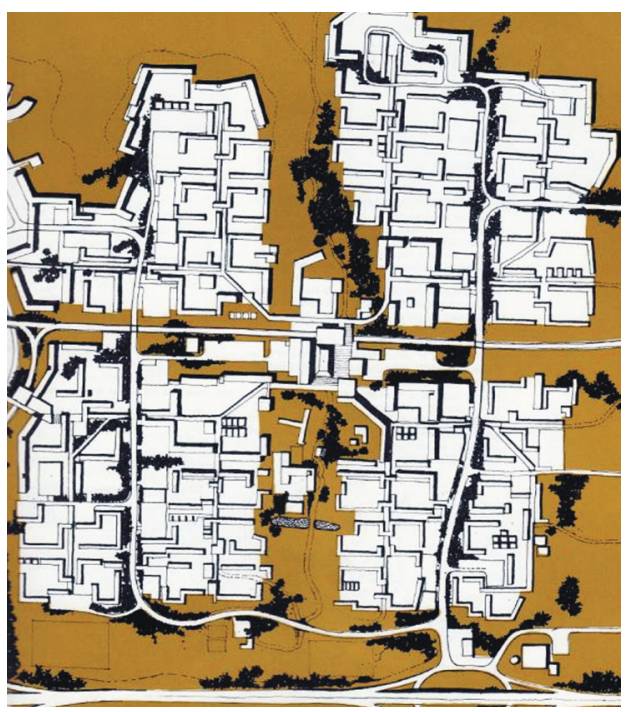

Figura 17: Plano para Runcorn, Arthur Ling and Associates - 1967: arranjo de uma área habitacional polarizada por um ponto de parada de transporte coletivo sobre pneus Fonte: RUNCORN DEVELOP CORPORATION, 1967

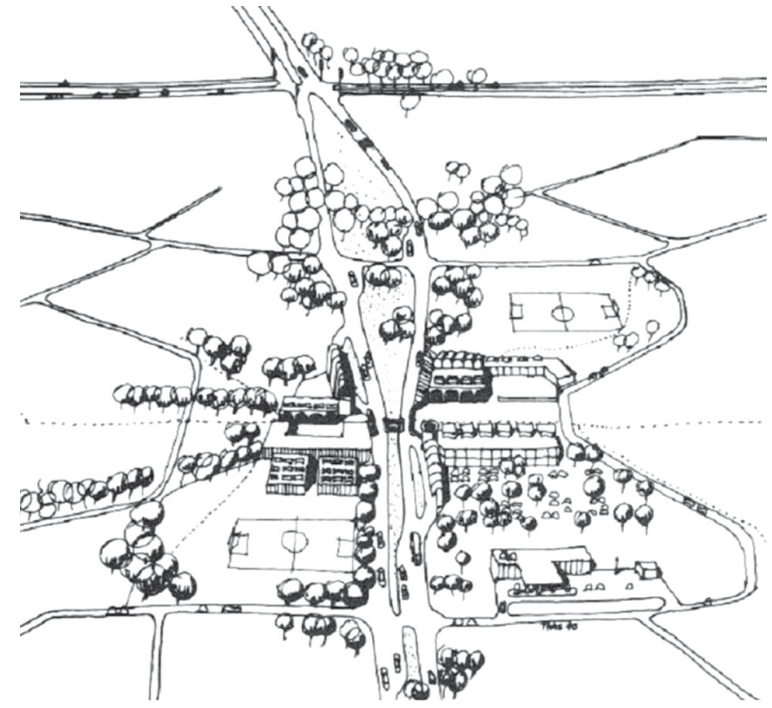

Figura 18: Plano Para Milton Keynes, LlewelynDavies Weeks Foresder-Walker \& Bor - 1970: conexão entre o sistema viário estrutural e as áreas habitacionais

Fonte: MILTON KEYNES DEVELOP CORPORATION, 1970 
xavam dúvidas quanto às características da forma de deslocamento urbano escolhida: flexibilidade, baixas densidades demográficas e boas velocidades médias.

Os princípios que deram suporte à concepção formal da estrutura urbana de Milton Keynes conduziam à solução em grelha, que não definia formalmente um centro pontual e que conformava uma série de unidades elementares de uso do solo, chamadas de environmental areas. As referências à Colin Buchanan, particularmente à Traffic in Towns ao Estudo para South Hampshire, já se apresentavam bastante evidentes.

\section{A vertente norte-americana da engenharia de tráfego}

No segundo pós-guerra os Estados Unidos eram o país com maior taxa de motorização do mundo. Por volta dos anos 1960, enquanto a Grã-Bretanha apresentava valores da ordem de 0,19 veículos/habitantes, nos Estados Unidos esta relação era mais de duas vezes superior, chegando a 0,41 veículos/habitantes (BUCHANAN, 1963).

A comparação destes indicadores para o ano de 1960 em algumas cidades norte-americanas e européias mostra diferenças médias da ordem de duas vezes, chegando a mais de três vezes, das primeiras em relação às segundas. Los Angeles neste momento já aparecia como exemplar significativo da motorização de sua população, com quase dois habitantes para cada automóvel registrado.

Valdes (1971) relaciona o crescimento dos índices de motorização ao aparecimento da engenharia de tráfego, como ramo específico da engenharia civil. Para ele, tanto nos Estados Unidos como no Reino Unido, a engenharia de tráfego se constituiu quando as taxas de motorização atingiram valores em torno de 0,11 veículos/habitante. Este valor, no entanto, foi observado em momentos diferentes nos dois países. Assim, enquanto nos EUA a engenharia de tráfego teria surgido durante os anos 1920 e 1930, no Reino Unido esta seria um fenômeno dos anos 1950.
Tabela 1: Taxa de motorização em cidades norte-americanas e européias em 1960

Fonte: KENWORTHY; LAUBE, 1999

\begin{tabular}{|c|c|c|c|}
\hline & Cidade & $\begin{array}{r}\text { População } \\
(1960)^{*}\end{array}$ & $\begin{array}{r}\text { Taxa de } \\
\text { motorização } \\
(\text { auto/hab)** }\end{array}$ \\
\hline \multirow{8}{*}{ EUA } & Boston & 2.589.301 & 0,27 \\
\hline & Chigago & 6.220 .913 & 0,31 \\
\hline & Detrit & 3.762 .360 & 0,37 \\
\hline & Houston & 1.430 .394 & 0,39 \\
\hline & Los Angeles & 7.823.721 & 0,46 \\
\hline & Nova York & 14.114 .927 & 0,27 \\
\hline & San Francisco & 2.648 .762 & 0,41 \\
\hline & Washington & 2.076 .610 & 0,29 \\
\hline \multirow{5}{*}{ Europa } & Amsterdam & 889.400 & 0,06 \\
\hline & Frankfurt & 670.048 & 0,13 \\
\hline & Londres*** & 7.992 .400 & 0,16 \\
\hline & Paris & 8.400 .000 & 0,15 \\
\hline & Copenhagen & 1.607 .526 & 0,09 \\
\hline
\end{tabular}


Da mesma maneira que no Reino Unido, em boa parte da Europa, a engenharia de tráfego só se afirmaria a partir do segundo pós guerra:

En Alemania y otros países centroeuropeus, la rápida y moderna reconstruccíon de las ciudades destruídas en la segunda guerra mundial contribuyó a impulsar la Ingeniería de Tráfico a partir de 1950, que dispuso de um amplio campo de acción y de experiencia" (VALDES, 1971: 9)

Colin Buchanan reconhecia esta precedência norte-americana e ressaltava suas preocupações com as tendências observadas no Reino Unido:

"It would be inappropriate to conclude a review of urban traffic problems without mentioning developments in the United States, where there exists a degree of dependence on motor transport far exceeding our own - but towards which we are moving" (BUCHANAN, 1958: 200)

A constituição da engenharia de tráfego 30 anos antes nos Estados Unidos permitiu a este país um papel de destaque no plano internacional, não exatamente como um formulador de uma teoria sistematizada sobre o tráfego urbano, mas principalmente como um organizador de parâmetros de projeto de vias, a partir da experiência construtiva acumulada e de pesquisas experimentais. Este papel foi amplamente amparado por uma política de prioridade ao automóvel.

O primeiro movimento norte americano para o tratamento da questão viária foi a criação do Bureau of Public Roads em 1916. A montagem de uma estrutura especificamente voltada ao assunto das vias públicas esteve ligada ao aumento da frota de automóveis já no início do século XX. Nestes anos, a produção em massa de veículos passou a se colocar com uma realidade. A produção do modelo Ford T, por exemplo, chegou a 15 milhões de unidades entre 1908 e 1923 (BUCHANAN, 1958); e o preço de cada unidade passou de US\$850 em 1908 para US\$290 em 1926 (GRUBLER, 1990). 
Alguns anos mais tarde, a promulgação do Federal Highway Act (1921) reconheceu a necessidade de se estabelecer uma rede viária estrutural, que deveria ser construída com apoio financeiro das instâncias federais. Para isto, se determinou que este sistema estrutural deveria comportar, no máximo, $7 \%$ do total das vias, havendo assim uma concentração de recursos naquilo que seria um sistema estruturador regional (WEINER, 1999).

No entanto, o foco aqui não era a rede urbana, mas sim um sistema nacional de conexões entre as principais cidades norte americanas. Já nos anos 1930 a tarefa seria completada, pelo menos no que diz respeito às ligações entre os grandes centros.

Também durante os anos 1930 a preocupação das autoridades se deslocaria para a qualidade dos projetos viários, já que o volume veicular vinha aumentando rapidamente, assim como o peso bruto total dos veículos. Vias como a Southern State Parkway, de 1927, por exemplo, embora recém-construídas já apresentavam dimensionamentos acanhados às novas demandas.

\section{Conforme Edward Weiner,}

“(...) Early highways were inadequate in width, grade, and alignment to serve major traffic loads, and highway pavements had not been designed to carry the number and weight of the newer trucks". (WEINER, 1999: 8)

Esta constatação abriu caminho para um grande esforço de pesquisa e desenvolvimento tecnológico do ponto de vista do projeto viário. Com este objetivo, o Federal-Aid Highway Act (1934) autorizou que 1,5\% do volume de recursos destinados à construção de novas vias poderia ser empregado em pesquisas, planos e análises econômicas para o projeto de vias expressas.

Pouco antes, entre 1927 e 1929, a American Association of State HIghway Officials - ASSHO publicou seus primeiros manuais de sinalização, inicialmente para vias rurais e depois para vias urbanas. A isto se seguiu um esforço de normatização dos procedimentos de projeto. Já nos anos 1930, um comitê conjunto, composto pela AASHO e a National

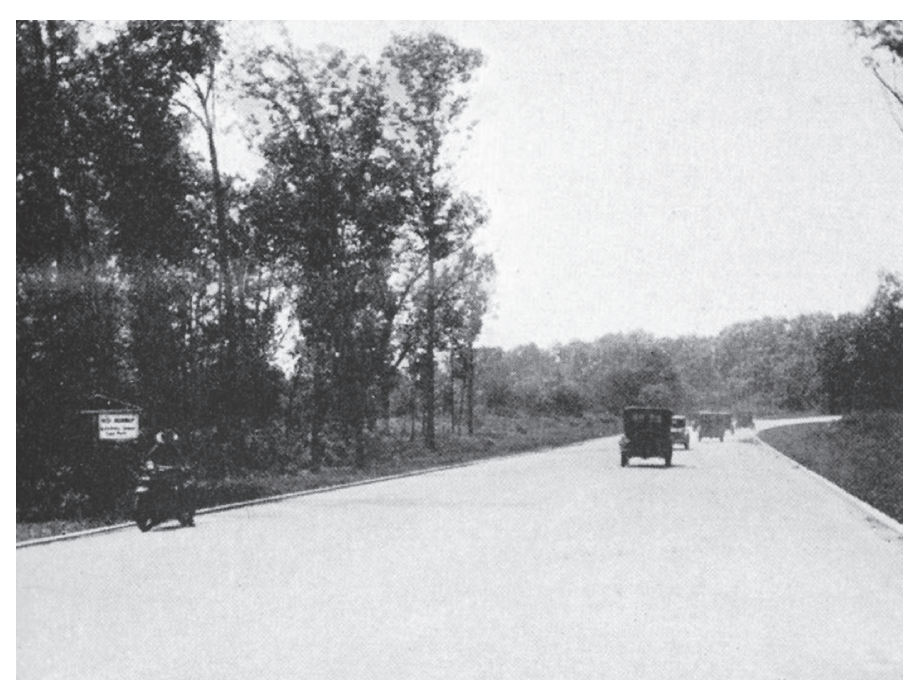

Figura 19: Southern State Parkway em 1927 Fonte: GUTFREUND, 2007: 87 


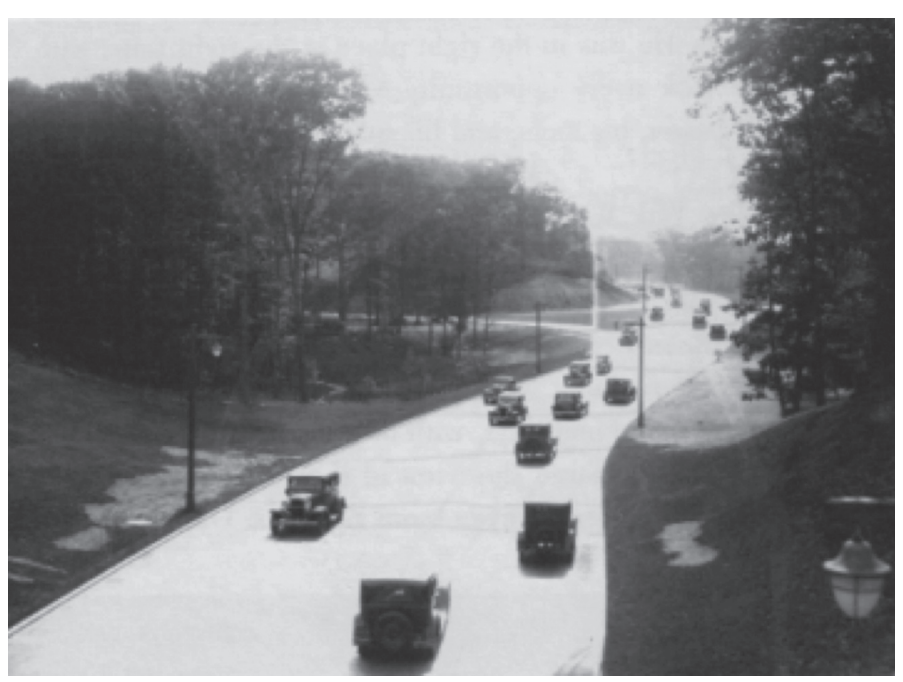

Figura 20: Grand Central Parkway, em janeiro de 1938, Nova York Fonte: GUTFREUND, 2007: 90
Conference of Street and Highway Safety, publicou o primeiro manual em 1935: Manual on Uniform Traffic Control Devices ${ }^{16}$ (WEINER, 1999).

Até a II Guerra Mundial, os mais notáveis projetos viários se destacavam por sua intenção de integrar o traçado viário com o sítio natural, criando cenários pitorescos. Eram as chamadas parkways, com suas generosas estratégias de concordância entre curvas verticais e horizontais. Tratavam-se de vias construídas nas áreas de expansão das cidades, em particular Nova Iorque, criando situações de novos assentamentos marcados pelo ideário de subúrbio jardim e suas baixas densidades.

A implantação destas parkways em Nova Iorque foi coordenada pela figura controversa de Robert Moses, que vinha se destacando como gestor de grandes projetos de infraestrutura nesta cidade desde os anos 1930. Foi ele também o coordenador responsável pela Exposição Internacional de Nova Iorque de 1939. Moses se destacaria posteriormente como um dos principais entusiastas de uma nova concepção de projeto viário que fundamentou a prática profissional norte-americana no segundo pós guerra.

A política de construção de vias do período pós II Guerra Mundial foi encabeçada pelo Federal-Aid Highway Act de 1944. Este Ato foi uma espécie recuperação dos investimentos governamentais em vias, frente ao impressionante crescimento do volume de tráfego nos Estados Unidos. Conforme Edward Weiner (1999), a produção de automóveis saltou de 70 mil unidades em 1945, para 2,1 milhões em 1946 e 3,5 milhões em 1947. Neste sentido, o Ato de 1944, autorizou um significativo aumento de fundos destinados à ampliação do sistema viário e sua capacidade.

O Gráfico 1 nos ajuda a compreender a relação entre demanda e oferta do sistema viário norte americano até 1955. Neste caso é notável uma primeira fase de crescimento da oferta e demanda até os anos 1930 e o período da grande depressão. Nos quinze anos seguintes até o final da II Guerra Mundial, houve uma discreta tendência de cresci-

16 Este manual foi editado pelo Bureau of Public Roads, e sofreu atualizações em 1942, 1948, 1961, 1971, 1978 e 1988 
mento da frota de veículos, que não foi acompanhada por investimentos em novas vias, sobretudo no período do esforço de guerra.

O Ato de 1944 parecia reconhecer a distância entre as taxas de crescimento da frota e a disponibilidade de vias. É notável como já a partir de 1945 o ritmo de crescimento dos investimentos em vias expressas superavam as taxas de crescimento dos registros de novos automóveis. Sobretudo após 1950, o investimento em infra-estrutura viária parece ter se tornado uma política de Estado, mais que uma resposta à demanda.

O ato de 1944 também esteve associado a uma mudança nos parâmetros dos projetos viários, nos quais Robert Moses desempenharia um papel central, particularmente em Nova Iorque (GUTFREUND, 2007). Meyer e Gómez-Ibánez (1981) denominam este período como "the highway era". Pode-se afirmar que os projetos que caracterizaram este momento passaram a ser orientados pelo princípio da eficácia da circulação e pela preocupação com a segurança do condutor. As condicionantes do entorno deixaram de ser um elemento de projeto, como nas parkways ${ }^{17}$. Em outras palavras, os aspectos relacionados à capacidade de tráfego, velocidade de projeto, raios mínimos, elementos de curva vertical, entre tantos outros passaram a serem considerados suficientes para a definição do projeto de via.

Marshall Berman (2007), comentado a ação de Robert Moses em Nova Iorque, traduz de forma definitiva esta transformação dos padrões de projeto:

"Os projetos de Moses das décadas de 1950 e 1960 não contém praticamente nada de beleza de design e da sensibilidade humana que distinguiram seus trabalhos anteriores. Dirija uns trinta quilômetros pela Northern State Parkway (anos 1920) e então faça o retorno e cubra essa mesma distância na via expressa de Long Island (anos 1950 e 1960), que lhe é paralela, e tente evitar a surpresa e o pesar (...)”.(BERMAN, 2007: 361)

Esta mudança da concepção do projeto viário foi acompanhada por um esforço de

17 A este respeito ver Anelli e Seixas (2009)

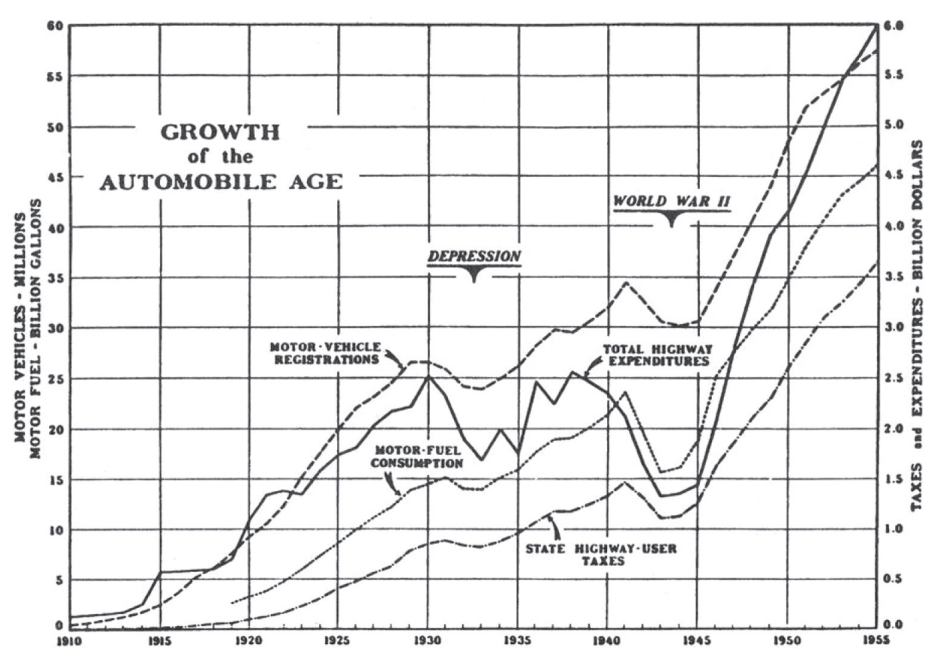

Gráfico 1: Registro de veículos, consumo de combustíveis, tributação e investimentos e novas Highways nos EUA: 19101955

Fonte: WEINER, 1999: 9 
sistematização na forma de manuais de procedimentos de projeto. Considerava-se necessário maior conhecimento sobre o desempenho dos veículos. Tratava-se também de uma estratégia de divulgação, na qual as características de projeto teriam mais disponibilidade para a incorporação à prática profissional.

Diante disto, o Committee on Planning and Design Policies, formado pela AASHO em 1937, revisou as publicações disponíveis naquele momento e as agrupou em um único volume em 1950. Este volume foi ainda atualizado e expandido numa edição conhecida como "Blue Book", A Policy on Geometric Design of Rural Highways (1954) (AASHO, 1965). Esta publicação teve sete reimpressões até 1965 e foi amplamente aceita como manual, não só nos Estados Unidos, mas também na Inglaterra e em outros países como o Brasil.

A situação dos novos projetos, inseridos em contextos urbanos, passou a colocar demandas mais específicas. Neste sentido, em 1957 o "Blue Book" ganhou uma versão destinada exclusivamente às vias urbanas, intitulado: A Policy on Arterial Highways in Urban Areas. A publicação deste manual, portanto, não parece ter sido ao acaso, mas afirmava uma clara guinada na concepção de projeto viário nos Estados Unidos: após um período de ampliação do sistema expresso interurbano, no segundo pós-guerra, priorizavam-se as ações no âmbito intra-urbano.

Ao mesmo tempo em que se avançava na pesquisa e na produção de conhecimento sobre de projeto geométrico e a tecnologia de construção viária, a partir dos anos 1930 houve numerosos estudos sobre questões relacionadas à capacidade viária, que culminaram no Highway Capacity Manual em 1950, organizado pela Highway Research Board.

Nessa concepção de projeto viário desenvolvida nos Estados Unidos, a circulação urbana era entendida como o mero movimento de pessoas e mercadorias; ou seja, um dado do problema, que raramente previa sua conexão com o planejamento urbano e de transportes (VASCONCELLOS, 1996).

Diante deste cenário de intensa motorização e conhecimento técnico acumulado, a ex- 


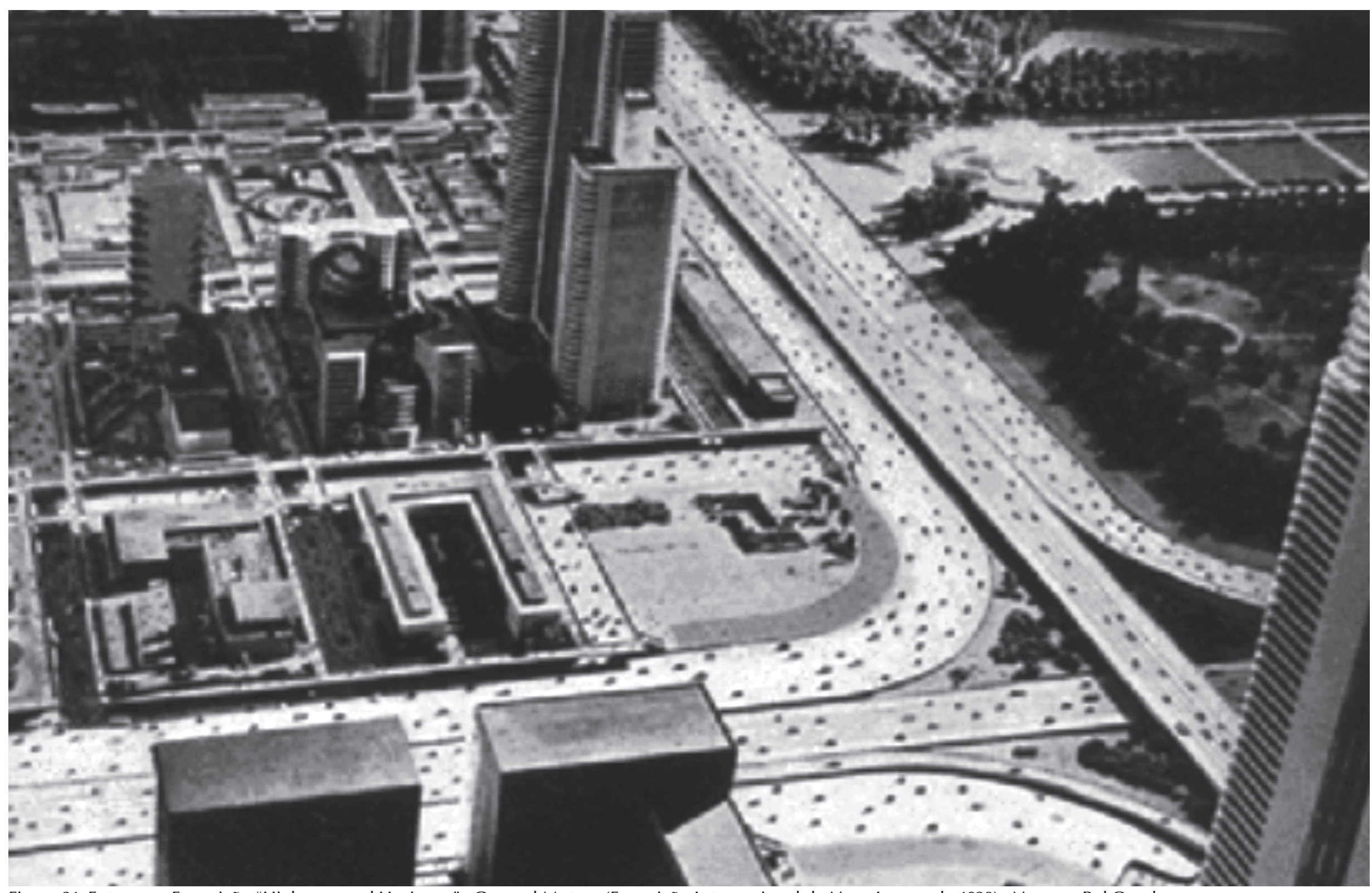

Figura 21: Futurama: Exposição "Highways and Horizons" - General Motors (Exposição Internacional de Nova lorque de 1939), Norman Bel Guedes Fonte: http://www.columbia.edu/cu/gsapp/projs/call-it-home/html/chapter10.1.html; consulta em 10 de julho de 2008 


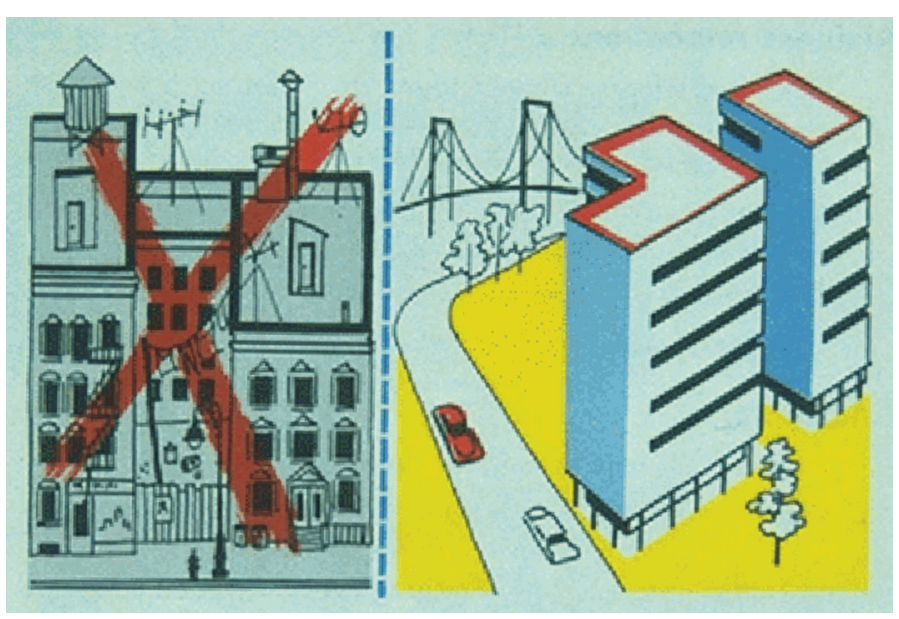

Figura 22: Imagem divulgada no livro You and Tomorrow's Roads - Esso Standard Oil Company, 1958 Fonte: http://www.columbia.edu/cu/gsapp/projs/call-it-home/html/ chapter10.3.html; consulta em 10 de abril de 2010 periência norte-americana se constituiu como um forte referencial no plano internacional. Conforme Vasconcellos: "A visão tradicional do planejamento da circulação está relacionada à grande influência da literatura norte-americana, que privilegia a intervenção como dedicada à 'otimização do espaço de circulação"' (VASCONCELLOS, 1996: 89)(grifo nosso).

Vasconcellos (1996) aponta também que a indústria automobilística, aliada aos crescentes índices de congestionamento foram dois dos mais importantes condicionantes da montagem desta visão de circulação urbana. O manual A Policy on Arterial Highways in Urban Areas, de 1957, apontava como uma de suas justificativas: "The ever-growing motor vehicle travel has resulted in increasing traffic congestion, with the greatest distress evidence in urban areas" (AASHO, 1965: 1)

De fato, embora colocada em prática no segundo pós-guerra, esta visão, que associava vias expressas a uma nova imagem de cidade, começou a ser gestada pouco antes, durante a década de 1930. Neste sentido, o pavilhão demonstrativo da General Motors na Exposição Internacional de Nova Iorque de 1939 parece ter tido papel de destaque. Foi nessa ocasião que a mostra "Highways and Horizons" apresentou a visão da cidade do futuro, incorporando uma série de vias expressas elevadas em meio a arranha céus ${ }^{18}$.

Quase vinte anos mais tarde, uma publicação da Esso Standard Oil Company (1958), intitulada "You and Tomorrow's Roads", reafirmava os valores associados à modernidade nas cidades e sua relação com novos padrões viários. Uma das ilustrações da publicação não deixava dúvidas quanto à transformação pretendida: a "velha" cidade constituída por altas densidades e circulação de pedestres, teria que ser substituída pela cidade "corbusiana", onde os carros assumiriam o papel privilegiado de meio de transporte.

Novamente, "A Policy on Arterial Highways in Urban Areas", de 1957, nos ajuda a

18 Discutimos este assunto em outra ocasião. A este respeito ver Anelli e Seixas (2009) 
compreender este ideário. Durante todo o texto do manual o meio urbano é raramente mencionado. As características físicas dos quatro tipos de vias estruturais considerados (major street, expressway at grade, freeway e parkway) sequer indica qualquer relação com o planejamento urbano, como densidade populacional, usos do solo etc. Ao mesmo tempo, os pedestres só são mencionados no momento em que se constituem numa impedância ao funcionamento da via: nas travessias.

Tabela 2: Características das vias arteriais urbanas, conforme o Manual "A Policy on Arterial Highways in Urban Areas", de 1957

Fonte: AASHO, 1962: 5

\begin{tabular}{|c|c|c|c|c|}
\hline $\begin{array}{l}\text { Projeto e } \\
\text { características } \\
\text { de controle }\end{array}$ & Vias principais & Vias expressas & Freeway & Parkway \\
\hline tipos de veículos & todos & todos & todos & $\begin{array}{l}\text { somente veículos } \\
\text { de passeio }\end{array}$ \\
\hline controle de acesso & normalmente não & total ou parcial & total & total ou parcial \\
\hline $\begin{array}{l}\text { interseção com vias } \\
\text { menos importantes }\end{array}$ & em nível & fechado & fechado & $\begin{array}{l}\text { normalmente } \\
\text { fechado }\end{array}$ \\
\hline $\begin{array}{l}\text { interseção com vias } \\
\text { mais importantes }\end{array}$ & em nível & $\begin{array}{l}\text { preferencialmente em } \\
\text { desnível; algumas em nível }\end{array}$ & $\begin{array}{l}\text { todas em } \\
\text { desnível }\end{array}$ & $\begin{array}{l}\text { em nível ou } \\
\text { desnível }\end{array}$ \\
\hline $\begin{array}{l}\text { controle de parada } \\
\text { e conversão do } \\
\text { tráfego em nível }\end{array}$ & $\begin{array}{l}\text { sinalização vertical } \\
\text { ou semafórica }\end{array}$ & $\begin{array}{l}\text { preferencialmente } \\
\text { sinalização vertical, } \\
\text { alguns semáforos }\end{array}$ & $\begin{array}{l}\text { todas em } \\
\text { desnível }\end{array}$ & $\begin{array}{l}\text { sinalização vertical, } \\
\text { semafórica ou } \\
\text { em desnível] }\end{array}$ \\
\hline acessos privados & $\begin{array}{l}\text { restritos, somente algumas } \\
\text { conversões à direita }\end{array}$ & nenhum ou poucos & nenhum & restritos ou nenhum \\
\hline $\begin{array}{l}\text { tratamento das } \\
\text { vias de acesso }\end{array}$ & $\begin{array}{l}\text { normal ou com } \\
\text { faixas de acelaração }\end{array}$ & $\begin{array}{l}\text { canalizados ou } \\
\text { em rampa }\end{array}$ & em rampa & $\begin{array}{l}\text { normalmente } \\
\text { canalizado ou } \\
\text { em rampa }\end{array}$ \\
\hline vias de apoio & normalmente não & onde necessário & $\begin{array}{l}\text { onde } \\
\text { necessário }\end{array}$ & $\begin{array}{l}\text { normalmente } \\
\text { não necessário }\end{array}$ \\
\hline canteiro central & incluído onde possível & incluído & incluído & normalmente incluído \\
\hline $\begin{array}{l}\text { travessias de } \\
\text { pedestres }\end{array}$ & faixas de pedestres & $\begin{array}{l}\text { faixas de pedestres ou } \\
\text { em desnível }\end{array}$ & desnível & $\begin{array}{l}\text { faixas de pedestres } \\
\text { ou em desnível }\end{array}$ \\
\hline $\begin{array}{l}\text { estacionamento } \\
\text { paralelo na via }\end{array}$ & $\begin{array}{l}\text { restrito ou eliminado } \\
\text { onde possível }\end{array}$ & eliminado & eliminado & eliminado \\
\hline $\begin{array}{l}\text { faixas de grama ao } \\
\text { longo dos bordos } \\
\text { da via (shoulders) }\end{array}$ & raramente aplicado & incluído & incluído & incluído \\
\hline
\end{tabular}




\section{LEGEND}

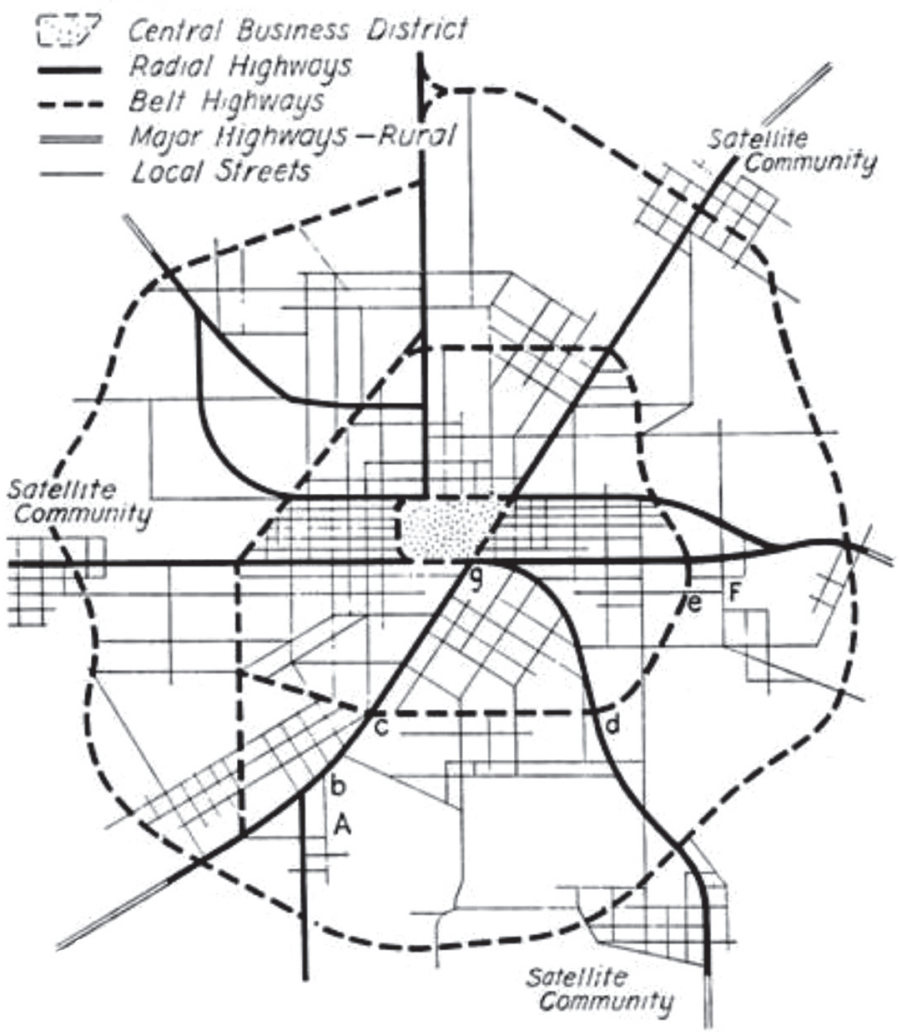

Figura 23: Padrão para vias arteriais urbanas, conforme o Manual "A Policy on Arterial Highways in Urban Areas", de 1957 Fonte: AASHO, 1962: 75
No entanto, contraditoriamente, há um modelo de cidade implícito, que não pode ser desconsiderado. A "nova" cidade seria palco de uma série de highways, dos tipos mais variados, desde vias com duplo sentido de circulação e com acessos aos lotes lindeiros, até aquelas completamente segregadas, conhecidas como freeways. Esta cidade combinaria ainda vias radias e vias perimetrais, que dariam margem a assentamentos dispersos, afastados do núcleo urbano central.

A construção desta poderosa tradição norte-americana na engenharia de tráfego não passou à margem de críticas internas. Lewis Mumford, por exemplo, chamava atenção para um equívoco fundamental deste ideário: assumir o automóvel como único modo de transporte. Para ele, era preciso melhores sistemas de transportes e não mais vias expressas. Criavam-se novas vias expressas para atender um centro já congestionado, fazendo ainda com que o usuário de transporte coletivo deixasse os modos públicos para usar o automóvel (MUMFORD, 1964).

Jane Jacobs parecia compartilhar da opinião de Munford, e complementava sua análise:

$\mathrm{Na}$ teoria, as vias expressas urbanas são sempre apresentadas como instrumento para desviar os carros de outras ruas e, portanto, aliviar o tráfego de outras ruas. Na prática, isso só funciona na eventualidade de as vias expressas terem um fluxo bem abaixo de sua capacidade; esquece-se de levar em conta o provável destino, fora da via expressa, desse fluxo maior de veículos. Em vez de servirem de via de passagem, as vias expressas servem quase sempre como desaguadouros". (JACOBS, 2000: 408)

Mumford e Jacobs dirigiam sua crítica não aos critérios técnicos adotados nos manuais, mas ao caráter da política de construção de vias expressas. Neste sentido, Munford formulava a questão fundamental:

"What's transportation for? 'This is a question that highway engineers apparently never ask themselves: probably because they take for granted the belief that transportation exists for the purpose of providing suitable outlets for the motorcar industry." (MUMFORD, 1964: 177-8) 
A conclusão de Mumford era ainda mais incisiva:

"When the American people, through their Congress, voted a little while ago (1957) for a twenty-six-billion-dollar highway programme, the most charitable thing to assume about this action is that they hadn't the faintest notion of what they were doing. Within the next fifteen years they will doubtless find out; but by that time it will be too late to correct all the damage to our cities and our countryside (...)” (MUMFORD, 1964: 176)

Colin Buchanan certamente acompanhou muito atentamente o desenvolvimento desta vertente da engenharia de tráfego e possivelmente conhecia também suas críticas. Ao longo de sua obra, a engenharia norte-americana apareceu sempre como um referencial para o debate acerca da circulação urbana. Ele mesmo realizou viagens de estudo aos Estados Unidos, uma delas por ocasião das pesquisas que se desenvolveram para a redação do relatório Traffic in Towns, e, portanto, conhecia in loco os seus resultados.

Para Buchanan, a engenharia de tráfego norte-americana já havia resolvido as questões de natureza construtiva do projeto de vias interurbanas. Quanto a isto não havia divergências. A questão fundamental para ele residia nos resultados desta política no meio urbano: "Many descriptions and eulogies of American work have been written, but seldom is there any frank evaluation of the positive benefits accruing to city life as distinct from the speeding motorist" (BUCHANAN, 1958: 201)

A situação se agravaria quando considerados os contextos urbanos britânicos. Em Traffic in Towns Buchanan ressaltava que as freeways eram inevitavelmente estruturas gigantescas inseridas no tecido urbano e que gerariam necessariamente grandes impactos negativos. Comentando os desdobramentos que uma só interseção destas vias poderia causar em Londres, alertava:

"One single interchange planned for the inner loop at Boston will take about 100 acres of land; if such an intersection were put down in London it might well be situated in an area where people were living at a density of 100 person per acre, so the displacement of 
population alone would be 10.000.” (BUCHANAN, 1963: 184)

Para Buchanan ficava evidente que seria necessário construir uma outra abordagem para a questão do tráfego urbano. Se a engenharia norte-americana havia avançado sobre questões construtivas, como ele admitia, no que diz respeito à questão urbana esta apresentava um viés pouco aplicável na situação britânica.

Boaga (1977) chama atenção para uma atitude ponderada de Buchanan sobre as realizações da engenharia de tráfego norte-americana. Para o engenheiro-urbanista britânico, as ações no âmbito da circulação urbana deveriam ser implantadas e monitoradas como política pública, "revisadas à luz da experiência". Neste sentido, Boaga ressalta que há uma clara divergência em relação à experiência americana, “(...) donde las disponibilidades financeras han evitado las preocupaciones de orden práctico y se han realizado com ligereza y demagogia series enteras de grandes vías." (BOAGA, 1977: 69)

De fato, a vertente norte-americana interessava a Buchanan sobretudo como contraponto, como uma oportunidade de se verificar os desdobramentos urbanos de uma política francamente favorável ao automóvel, que acentuava ainda uma característica que o engenheiro-urbanista britânico vinha criticando desde 1958: a separação entre planejamento urbano e planejamento de tráfego. Em outras palavras, Buchanan, em sua síntese, indicava que as questões construtivas colocadas pela vertente norte-americana não solucionavam sozinhas o problema do automóvel na cidade.

Ao analisar o contexto do debate sobre urbanismo e circulação urbana nos anos 1950 e 1960, buscamos apresentar os principais elementos referenciais para a obra de Colin Buchanan. Os aspectos discutidos neste capítulo servirão de suporte para o debate central proposto nesta tese, que se desdobrará nos próximos quatro capítulos, quando discutiremos a obra de Buchanan a partir de quatro dimensões da escala da cidade. 


\section{capítulo 3}

\section{A mobilidade urbana como questão política}

Ao discurso que procura associar desde o início planejamento urbano e transportes, Colin Buchanan associa a dimensão política da mobilidade urbana como questão essencial no enfrentamento dos problemas da expansão dos automóveis e seus impactos sobre as cidades.

Em seu livro de memórias, o engenheiro-urbanista ressalta que as questões conceituais de Traffic in Towns são um desdobramento de seu primeiro livro, mas adverte: "Virtually all the rest of the report was devoted to the choices available to the authorities and through them to the public." (BUCHANAN, 2002: 66)

Embora assegure que a escolha se dá no âmbito político, Colin Buchanan se esforça por pautar seu discurso sobre a irreversibilidade da presença do automóvel na cidade. Em outras palavras, ele próprio se empenha pela construção de uma clara escolha deste modo de transporte em detrimento de outros. E isto se dá num ambiente político bastante favorável às suas teses.

Ao mesmo tempo, o discurso do engenheiro-urbanista defende uma nova forma de participação do Estado na questão da mobilidade urbana. Assentado na investigação sobre as razões da separação histórica entre as áreas de planejamento urbano e 
transportes, Colin Buchanan procura dar contornos a uma forma de enfrentamento da questão dos transportes urbanos, que passamos a denominar "planejamento da mobilidade urbana".

\section{A opção pelo automóvel como modo de transporte urbano}

A obra de Colin Buchanan pode ser caracterizada pelo seu entusiasmo pelo automóvel como modo de transporte urbano e suas potencialidades para o futuro. Desde seu primeiro livro publicado, Mixed Blessing, o engenheiro-urbanista britânico procurou afirmar um discurso em que a motorização era considerada como um destino inevitável, mas que deveria ser administrado corretamente para controlar seus efeitos adversos. Ainda que relativizado, sobretudo no período após 1964, este tom de discurso acompanharia toda sua carreira como consultor. Em 1966, em uma conferência no Instituto de Engenharia em São Paulo, Colin Buchanan afirmava,

"Eu penso que deveria reenfatizar a intrínseca utilidade do veículo motorizado. Eu freqüentemente ouço dizer que o veículo motor deveria ser eliminado, e que outros métodos de transporte deveriam ser desenvolvidos etc. Mas quando venho a considerar em um modo prático o tipo de movimento que ocorre nas áreas urbanas - o seu número imenso, variedade e complexidade (...) eu sempre volto à conclusão de que o veículo motor, ou de alguma forma dele derivada, está tão bem adaptado a esses movimentos que é inevitável a sua manutenção como principal instrumento de transporte urbano". (BUCHANAN, 1967: 10)

A sua linha de argumentação caminha no sentido de justificar o automóvel do ponto de vista do equilíbrio econômico do país e minimizar suas responsabilidades em alguns processos de expansão urbana criticados naquele período. Ao mesmo tempo, deslocava a questão do automóvel, como meio de transporte urbano, para a forma de enfrentamento dos problemas originados a partir do crescimento do número de veículos, tanto 
pela engenharia de tráfego como pelo planejamento urbano.

Como já afirmado, esta estratégia de argumentação foi montada já nos anos 1950 e sistematizada no seu primeiro livro, Mixed Blessing. Não por acaso, como veremos adiante, este enfoque o qualificaria para o posto de coordenador das pesquisas no relatório Traffic in Towns, dois anos mais tarde.

O discurso de Buchanan no seu livro Mixed Blessing se inicia recuperando as origens do automóvel, desde sua invenção na segunda metade do século XIX, por Carl Benz e Gottlib Daimler, até a popularização dos modelos leves no início do século XX, em especial o Ford T. O período do imediato pós II Guerra foi, segundo ele, caracterizado pela melhoria da relação peso-potência e ampliação dos mercados para os modelos leves.

Esta mudança tecnológica nos veículos foi acompanhada pela expansão da indústria automotiva no Reino Unido. Colin Buchanan analisou cuidadosamente este assunto, dedicando uma parcela significativa do livro a ele; reconhecendo que: “(...) No review of the development and influence of the motor vehicle would be complete without a brief reference to the manufacturing industry" (BUCHANAN, 1958: 42).

Naquele momento a indústria automobilística respondia por $13 \%$ das exportações do país; representando, sem dúvida, um peso importante na balança comercial. Enquanto em 1938 a relação entre produção interna e produção para exportação era 419 mil unidades para 84 mil; em 1951 esta relação já era de 414 mil unidades (ou seja, praticamente estável) para 506 mil unidades para exportação. (BUCHANAN, 1958)

Este setor da indústria era dominado por cinco grandes montadoras - British Motor Corporation, Rootes, Vauxhall, Ford and Standard - além de outras 25 fábricas de menor porte. Além disso, Buchanan estimava que dois terços do total de um automóvel fossem representados por componentes produzidos por outras unidades industriais, as indústrias de autopeças. Operando associadamente, havia ainda o setor de lubrificantes, pneus e combustíveis. 
Ou seja, Buchanan identificava neste momento uma cadeia produtiva que envolvia desde grandes montadoras até pequenos negócios, como manutenção de veículos, passando por questões complexas como a importação de petróleo de vários países, sobretudo o Kuwait. Este setor sozinho, ressaltava ele, era responsável por mais de dois milhões de empregos na Grã-Bretanha em meados dos anos 1950. Neste cenário, a cadeia produtiva ligada ao transporte estava entre as três grandes empregadoras do país; e significativamente acima do setor ferroviário.

Diante desta constatação concluía:

“(...) An extraordinary feature of the situation is that the motor is playing a dual role, not only has it made itself indispensable for transport purposes for people and goods alike, but it has also made itself a vital item in our export trade. It is a complication and a danger that these two major roles are not entirely independent and if something is wrong with the one, the other is likely to be affected too. (BUCHANAN, 1958: 57)

É sobre esta relevância do papel econômico da cadeia do setor de transportes, particularmente ligado aos automóveis, que Colin Buchanan montou uma parte significativa de sua linha de argumentação. Não se tratava apenas de reconhecer a importância como poder de pressão política deste setor, mas também seu alcance social como geradora de empregos e de recursos externos para o país. Neste sentido, admitindo os argumentos do autor, não haveria espaço para um caminho de volta.

Retomando a relação entre produção para mercado interno e exportação entre 1938 e 1951, mencionado acima, vemos como o livro de Buchanan (1958) situa-se num momento crucial da questão do automóvel no Reino Unido. De fato, neste intervalo de pouco mais de 20 anos a indústria se tornara muito mais presente na economia do país. Era além de um assunto de natureza urbana, uma questão de Estado.

Neste sentido, é reveladora a comparação do discurso de Colin Buchanan nesta ocasião, com um clássico britânico da literatura sobre tráfego urbano: o livro de Alker Tripp,
Tabela 3: Pessoas empregadas pela cadeia produtiva ligada ao transporte sobre rodas na Grã-Bretanha. Ano base 1956.

Fonte:BUCHANAN, 1958: 56

\begin{tabular}{|l|r|}
\hline Motoristas do serviço público & 261.100 \\
\hline Motoristas particulares & 20.000 \\
\hline Taxis e carros alugados & 24.000 \\
\hline Transporte de mercadorias (licensas A e B) & 225.000 \\
\hline Transporte de mercadorias (licensa C) & 638.000 \\
\hline Fabricação de motores & 335.000 \\
\hline Fabricação de partes de autos e acessórios & 101.000 \\
\hline Garagens e lojas de autos & 288.000 \\
\hline Indústria de pneus e óleo & 50.000 \\
\hline Construção e manutenção de vias & 96.000 \\
\hline total & 2.038 .100 \\
\hline
\end{tabular}

Tabela 4: Pessoas empregadas por ramo de atividade na GrãBretanha. Ano base 1956 Fonte:BUCHANAN, 1958: 56

\begin{tabular}{|l|r|}
\hline Agricultura, sivicultura e pesca & 682.760 \\
\hline Mineração & 861.670 \\
\hline Química e afins & 529.490 \\
\hline Industrial de aço & 583.230 \\
\hline Engenharia, construção naval e mercadorias elétricas & 2.117 .320 \\
\hline Industria e manutenção de aviões & 260.550 \\
\hline Industria e manutenção de locomotivas & 160.430 \\
\hline Industria textil & 938.030 \\
\hline Industria de vestuário & 639.050 \\
\hline Alimentos, bebidas e tabaco & 890.150 \\
\hline Construção civil & 1.419 .390 \\
\hline Gas, Eletricidade e abastecimentos de água & 379.140 \\
\hline Ferrovia (operação) & 500.840 \\
\hline Aviação (operação) & 32.930 \\
\hline Comércio & 2.408 .280 \\
\hline Administração Pública & 1.310 .090 \\
\hline
\end{tabular}


"Roads Traffic and its Control". O livro de Tripp foi publicado inicialmente em 1938 e se destacou por abordar, de maneira pioneira, a questão do tráfego do ponto de vista de sua gestão, chegando até mesmo a discutir as implicações urbanas da circulação. No entanto, embora o autor tivesse se notabilizado como inspetor chefe da Scotland Yard para assuntos de tráfego, sua análise não chegou às implicações econômicas da questão do automóvel. Em outras palavras, esta questão parecia não estar colocada para o Reino Unido vinte anos antes, no período pré II Guerra Mundial.

A pujança econômica do pós II Guerra Mundial e a constituição de um parque industrial bastante calcado na indústria automobilística contribuíram para um significativo aumento da frota de veículos, que em meados dos anos 1950, já era de mais de seis milhões de unidades em circulação. Buchanan então procurou discutir as conseqüências sociais e as formas de urbanização a partir do automóvel:

“(...) It is in fact a remarkable picture of an economic revolution which has taken place so quietly and insidiously that our present substantial degree of dependence of the motor vehicle is probably not very widely recognized. This great change has not taken place without its social impact. The motor has had a profound influence upon the development of towns, and so upon the way of life of a large part of the population". (BUCHANAN, 1958: 58)

Se Buchanan reconhecia o impacto do automóvel nas cidades britânicas, ao mesmo tempo, minimizava sua responsabilidade em relação aos problemas urbanos de então. Para ele, não era somente o aumento da frota de veículos o que explicaria os problemas emergentes, mas o próprio processo de urbanização do século XX teria participação significativa.

A principal questão neste caso estaria relacionada ao crescimento dos assentamentos de menor densidade, que avançavam sobre áreas até então cultiváveis. Se os automóveis estimulavam este processo, alertava também que os anos 1920 haviam coincidido com um período de profunda depressão dos negócios agrícolas e a conseqüente venda das 
terras pelos proprietários; fato comentado também por Bruegmann (2005).

O posicionamento de Buchanan em relação a este assunto pode ser mais bem compreendido pelo discurso de J. Michael Thomson (1977). Para ele, foi a urbanização do século XX que denunciou a falta de capacidade de gerenciamento das questões de circulação e não simplesmente o aumento da frota de automóveis:

"It is so easy to say that the problem has arisen from the growth of the car ownership. But this does not go deep enough to provide a satisfactory explanation. It can be argued, for a start, that similar problem would have arisen even if the car had never been invented or allowed on the public highway. A car is a convenient means of private transport and would presumably have acquired horse-drawn vehicles could have produced much the same impasse; their speed is not dissimilar from that of much modern city traffic and their range is sufficient for the great majority of city journeys. They are quite capable of killing pedestrians; they have their own parking problems and their own brand of pollution. All these problems were well known in the centres of large cities before the arrival of the motor car." (THOMSON, 1977: 60)

Buchanan, assim como Thomson, creditava os problemas decorridos da expansão dos automóveis à falta de capacidade de gerenciamento urbano. Ainda assim, não se pode afirmar que os problemas associados ao tráfego não existiam. Smeed (1968) relatou que a velocidade na hora pico na área central de Londres em 1962 era de aproximadamente $16 \mathrm{Km} / \mathrm{h}$.

O próprio Colin Buchanan mencionou a pesquisa London Travel Survey de 1949, elaborada pelo London Transport Executive, com os seguintes resultados: 58\% das viagens de trabalho eram feitas por transporte coletivo (34\% ônibus e $12 \%$ ferrovia) e $42 \%$ por outros modos, que incluíam 31\% por bicicleta ou a pé e 5\% por automóveis ou motocicletas. Como ele mesmo afirmou "(...) the great importance of the road vehicle is apparent” (BUCHANAN, 1958, 29). A mesma situação ocorreria em Cardiff, para a qual desenvolveu um estudo em 1966, onde a distribuição modal apresentava uma grande participação dos ônibus em relação aos automóveis, $80 \%$ contra $20 \%$.

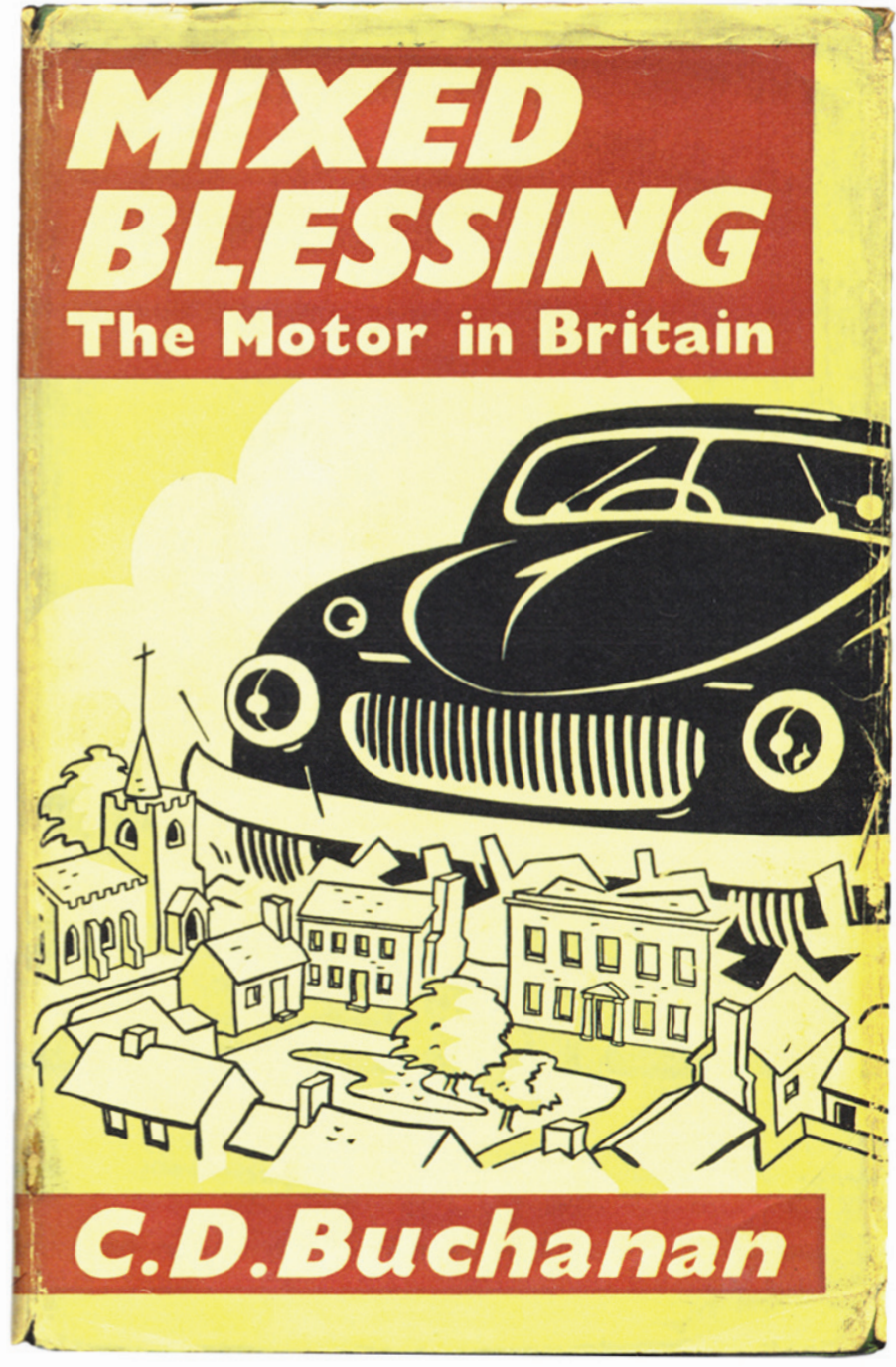

Figura 24: "Mixed Blessing: the motor in Britain", publicado em 1958 (Сара) 


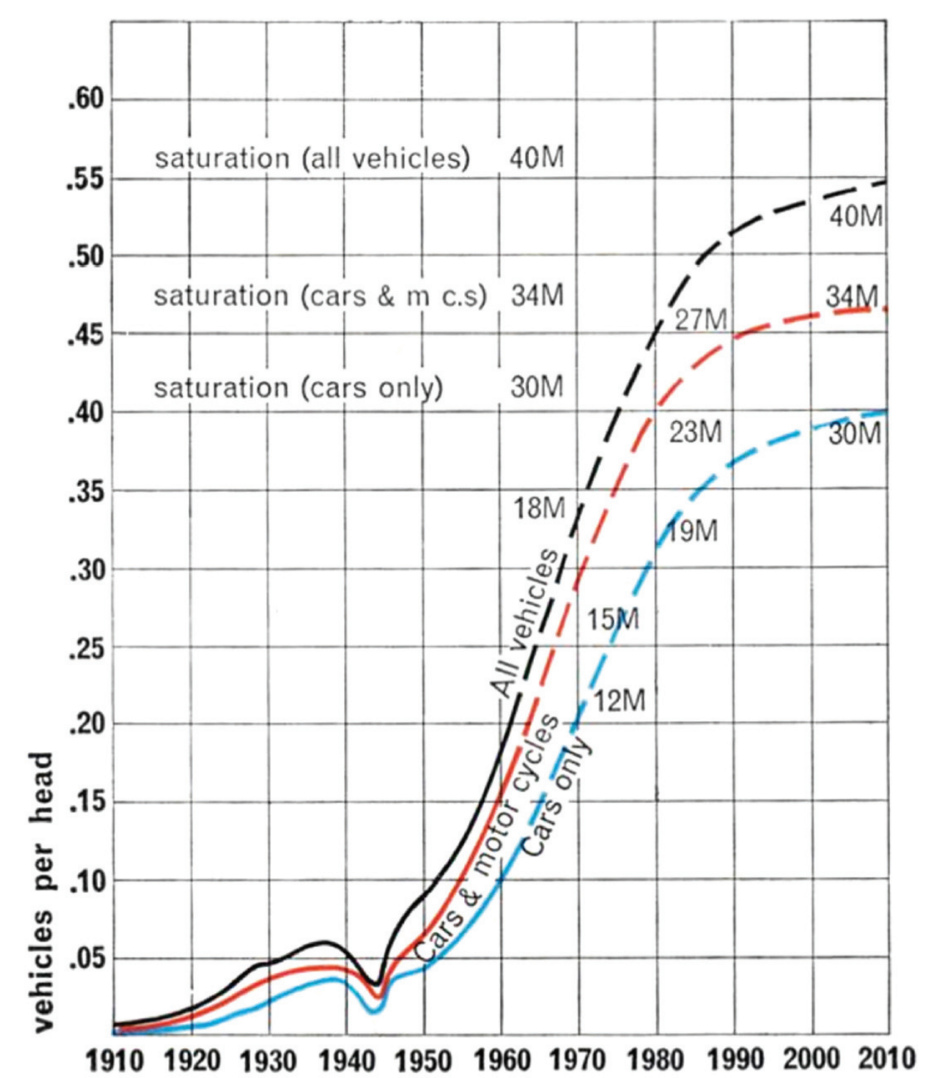

Gráfico 2: Traffic in Towns: taxas de crescimento e previsão de crescimento da frota de veículos Fonte: BUCHANAN, 1963: 27
Portanto, tratava-se mais de anunciar um problema futuro do que propriamente reverter um quadro já consolidado. A imagem escolhida como ilustração da capa de seu livro não deixa dúvidas sobre suas perspectivas. Para ele, o Reino Unido seria varrido dramaticamente pelo automóvel e suas cidades seriam muito afetadas, caso nada fosse feito.

O cenário delineado por Buchanan neste sentido apoiava-se nas projeções de crescimento da frota e da população, que vinham apresentando taxas generosas desde meados dos anos 1950. Este argumento seria plenamente desenvolvido por ocasião do relatório Traffic in Towns, concluído em 1963.

Segundo os cálculos elaborados para o relatório a frota de automóveis, que estaria em torno de 6,6 milhões em 1963, multiplicar-se-ia por mais de quatro vezes até 2010, chegando a 30 milhões de unidades e 40 milhões de veículos, incluindo todos os tipos e motocicletas. Neste ano, ocorreria então a saturação da taxa de motorização em 0,405 automóveis/habitantes, contra os valores de 0,16 registrados no início dos anos 1960.

As estimativas de Traffic in Towns para os anos 2000 chegaram a valores bastante próximos aos observados em relação aos automóveis. Em 2009, o Reino Unido contava com aproximadamente 31 milhões de unidades. As projeções, no entanto, superestimaram o crescimento da população, que ficou 12 milhões de habitantes abaixo do previsto, estimada em 74 milhões de habitantes (BUCHANAN, 1963).

As estimativas de crescimento empregadas no relatório desde o início foram motivo de controvérsia. O período do imediato pós-segunda guerra mundial foi marcado pelas altas taxas de natalidade, que decaíram progressivamente a partir dos anos 1950. Hall (2002) e Ward (2002) mostram que as projeções populacionais foram revistas no Reino Unido, considerando taxas de crescimento mais modestas, a partir dos anos 1960.

No entanto, Beesley e Kain (1968) criticaram um outro aspecto das estimativas. Para eles, o modelo de simulação para geração de tráfego, empregado em Traffic in Towns, era "supreendentemente" superado em pelo menos dez anos, sendo tributário do modelo 
utilizado para Detroit em 1952. Para os autores, havia uma série de simplificações no modelo que conduziam a conclusões imprecisas e até mesmo equivocadas. O estudo de caso de Leeds, desenvolvido no relatório, concluía que a motorização naquela cidade apresentaria taxas 25\% maiores que as observadas nos Estados Unidos.

Ao que tudo indica, os argumentos utilizados por Colin Buchanan, que partiam da constatação do papel econômico do automóvel, minimizavam sua responsabilidade nos problemas observados nos novos assentamentos e chegavam a previsões generosas de aumento da frota. Neste sentido, tinham menos um caráter científico e mais a função de legitimar uma característica de seu discurso.

"Our conclusion, therefore, is that the future of the motor vehicle, or some equivalent machine, is assured. We think it follows that a close, constructive examination must be made of towns and cities in order to see how the best use of the motor vehicle can be achieved in those places and how the present difficulties can be overcome". (BUCHANAN, 1963: 25)

As palavras de Buchanan, mencionadas acima, deslocavam claramente as possibilidades de discussão sobre possíveis alternativas em relação aos modos de transporte para os seus efeitos sobre o desenvolvimento urbano. Em outros termos, para ele, o automóvel era uma escolha política da área de transportes e cabia ao relatório Traffic in Towns fornecer as bases conceituais de uma política de Estado em relação aos problemas urbanos emergentes a partir do aumento da frota de automóveis (BEESLEY; KAIN, 1968).

$\mathrm{Na}$ construção deste discurso Buchanan, curiosamente, omitiu qualquer comparação mais sistemática em relação aos modos sobre trilhos. Em Mixed Blessing, discretamente, apontou que o setor da economia ligado aos automóveis tinha maior capacidade de gerar empregos que o setor ferroviário. Em Traffic in Towns apenas se limitou a argumentar que os automóveis apresentavam muito mais versatilidade que as ferrovias (BUCHANAN, 1963). Esta omissão não deixa de ser sugestiva. Ao que parece, Buchanan utilizou este recurso como uma forma de se preservar de um embate mais incisivo com um poderoso 
setor técnico e econômico britânico.

Desde a primeira metade do século XX o setor de transporte sobre trilhos constituía um oponente de peso às ações de melhoria das condições de circulação do automóvel. Dupree (1987) traçou um interessante quadro neste sentido:

“Therefore, when Howard's book Tomorrow, a peaceful path to real reform (Howard, 1898) was published towards the turn of the century, industry was booming, labour was abundant and cheap, there was a magnificent railway system, and the cities had expanded beyond recognition, stately squares of Victorian elegance for the minority and slum dwellings in the industrial cities for the majority. With so much engineering talent, labour strength and capital investment devoted to the railways, no much advance was made in improving the road network or the technique of roadbuilding"' (DUPREE, 1987: 11)

No mesmo período em que foi desenvolvido Traffic in Towns, o setor ferroviário foi contemplado com o Beeching Report, que estudou a reformulação do sistema para combater os crescentes déficits operacionais. Assim como o relatório de Buchanan, o similar do setor ferroviário foi também discutido no meio técnico do período.

Nem mesmo Geoffrey Crowther, presidente do Grupo Diretivo da equipe de Traffic in Towns, era tão assertivo em relação à opção pelos automóveis quanto Colin Buchanan. Para ele, as alternativas de políticas públicas para a questão da expansão do automóvel envolveriam algum grau de restrição de tráfego e até mesmo investimento em transporte público, preferindo a combinação de ações, mais do que a aposta em uma única alternativa (BUCHANAN, 1964a).

Neste ambiente de embate, o discurso de Colin Buchanan parece ter surgido num momento muito oportuno da história do automóvel no Reino Unido. Apesar do esforço das New Towns, após a II Guerra Mundial o investimento em planos e políticas de transportes havia sido limitado. Além disso, o período até o início dos anos 1950 fora também marcado por uma política de racionamento dos combustíveis (GRANT, 1977). 
Tal panorama de contenção se transformaria nos anos finais da década de 1950, sendo marcado pela retomada do crescimento econômico e pelo fim da escassez de petróleo.

Em paralelo, o problema do automóvel na cidade havia atingido uma dimensão política considerável. Neste sentido, as considerações de Geoffrey Crowther eram reveladoras:

“(...) A majority of the voters in this country will soon be car-owners. Moreover, a carowner takes his car-owning seriously - it becomes one of the major interests of his life. The politicians will take notice of this. They will be anxious to please the motorist, and frightened of annoying him. This may greatly complicate the problem, as it will make drastic action politically difficult if it appears likely to meet with opposition among carowners" (BUCHANAN, 1964a: 11)

Neste contexto foi promulgado o Highways Act de 1959, que consolidou a legislação prévia, garantindo a subvenção de $75 \%$ dos custos de desapropriação e construção de vias estruturais em áreas urbanas. Por meio dele um grande esforço de construção viária foi viabilizado até o início dos anos 1970 (GRANT, 1977). Este Ato governamental surgiu no momento em que o planejamento de transportes tornava-se progressivamente mais importante, tanto na escala local como na regional.

"The increased availability of funds, the rise in car ownership, population growth trends, the development of a wide array of techniques, sets of data and a transport planning procedure each encouraged developments in urban transportation planning" (GRANT, 1977: 11)

Neste contexto, o discurso de Colin Buchanan encontraria campo fértil. Assim, se a publicação de Mixed Blessing abriu o caminho, os trabalhos de Traffic in Towns se consolidariam como uma visão de Estado: “(...) The 1959 Act provided funds; the Buchanan Report, as Traffic in Towns was known, offered direction; and the growth in car ownership provided an impetus for action" (GRANT, 1977: 48). Não foi por acaso que em janeiro de 1964 o governo britânico divulgou um informe (Circular 1/64) aconselhando as autorida- 
des locais a produzirem planos consistentes conforme as indicações de Traffic in Towns.

Observado nesta sequência de fatos, a grande repercussão do discurso construído por Colin Buchanan dava claras indicações de seu alinhamento político com o Partido Conservador britânico. No poder entre 1951 e 1964, pelo menos uma parcela significativa deste partido alimentava uma visão favorável em relação ao automóvel, conforme sugere Grant (1977).

Ao mesmo tempo, o discurso de Buchanan parecia bastante assimilável pelo setor automobilístico. Starkie (1982), comentando o processo de escolha do engenheirourbanista como coordenador do grupo de trabalho de Traffic in Towns, reforça o fato histórico de que Ernest Marples havia se impressionado com Mixed Blessing, mas ressalta discretamente que:

"However, Sir Richard Clarke reported that one of the most important factors leading to the commissioning of the Buchanan Report was the deliberation of a joint study group of the Society of Motor Manufactures and Traders, the Treasury and the Ministry of Transport set up to examine the implications of the great expansion of the car population upon which the motor industry's production plans were based" (STARKIE, 1982: 31)

Grant (1977) lembra ainda que o retorno ao poder do Partido Trabalhista em 1964 deu ímpeto a uma política de restrição do uso de automóveis, como controle de estacionamentos, pedágios e outros métodos; assim como o surgimento da questão do subsídio ao transporte público para as maiores aglomerações urbanas. Estas diretrizes se consolidariam por meio do Transport Act de 1968, que deu início a um novo período na política de transportes britânica (GRANT, 1977).

Buchanan não seria insensível a este novo momento político. Seus trabalhos como consultor indicam a incorporação do discurso dos transportes públicos à sua prática profissional, ainda que a aposta no automóvel se mantivesse presente. Ao mesmo tempo, ao que parece, os planos de seu período como consultor o colocaram diante 
da demanda concreta dos transportes públicos, o que possivelmente o tenha feito reavaliar seus conceitos.

Bem mais tarde, o engenheiro-urbanista relativizaria sua visão em Traffic in Towns: "Maybe I was overdoing things a bit in seeing motors and roads as in independent system (...)" (BUCHANAN, 2002: 71). No entanto, a reavaliação mais incisiva veio em 1975, por parte de Anne MacEwen, membro da equipe de Traffic in Towns e depois também de seu escritório de consultoria:

"After twelve years, six of them working with dinosaurs, trying to apply the priciples of Traffic in Towns it was time to reconsider the report. Were we to be sarting the study then, that is in 1975, in what way would our approach have been different? My first thought concerned the brief. To take public transport fully into account, the brief would have to be for a study not of traffic but of transport in towns (...).” (BUCHANAN, 2002: 125)

A mudança de foco de MacEwen não é descontextualizada. Nos anos 1970, haveria de fato uma mudança de foco dos investimentos para o transporte coletivo. Mesmo na obra de Buchanan, esta mudança é observada a partir de meados dos anos 1960, como trataremos mais adiante.

\section{A construção de uma nova forma de abordagem do problema da mobilidade na esfera pública}

Colin Buchanan, sobretudo em Mixed Blessing, empreendeu um grande esforço de recuperação das origens do tratamento da questão da circulação urbana. Este esforço redundou na construção de um discurso que, conforme ele, evidenciaria a história da autonomia entre duas questões do planejamento: o tráfego urbano e os relativos à organização do uso do solo.

O foco desta discussão para Buchanan não era a circulação urbana, encarada como 
possibilidades para todos os modais de transporte, mas sim o enfrentamento do Estado em relação ao problema gerado a partir do crescimento da frota de automóveis. Com este objetivo, seu discurso recuperou um tipo de ação do Estado Britânico em relação à questão: os Atos Governamentais ou simplesmente Acts, muito característicos da forma Britânica de legislar sobre os mais diversos assuntos.

Para ele, desde o século XIX e durante a primeira metade do século XX os problemas gerados a partir do aumento da frota de automóveis e os desafios relacionados à gestão do uso do solo foram encarados pelo poder público em duas frentes: os Traffic Acts e os Planning Acts. Os primeiros poderiam ser caracterizados por ações que objetivavam minimizar os impactos surgidos a partir do automóvel como meio de transporte e de suas transformações tecnológicas. Já os segundos, seriam marcados tanto pela ausência da questão da circulação, como pelo seu tratamento equivocado.

A partir desta proposta de enfretamento como campos autônomos, Buchanan pretendia mostrar como as origens distintas das esferas dos planejamentos urbano e de circulação tinham profundas implicações no tratamento da questão do tráfego urbano e seus impactos sobre as cidades. Em linhas gerais, a leitura elaborada por Colin Buchanan foi reafirmada por outros autores.

O planejamento urbano esteve em sua origem bastante ligado a melhoria das condições de habitação. O século XIX havia presenciado uma impressionante urbanização, fruto do processo de industrialização, que foi acompanhado pela deterioração das condições de moradia. O planejamento urbano nasceu então no seio de correntes sanitaristas, sobretudo como forma de erradicar epidemias associadas às formas precárias de moradia e saneamento (CULLINGWORTH\&NADIN, 2007). Não por acaso, a ênfase das preocupações urbanas do século XIX no Reino Unido recaia sobre as áreas de moradia e não nas questões de circulação. Era o Ministério da Saúde Britânico o responsável pelo planejamento urbano.

Leonardo Benevolo reafirma esta visão: 
“(...) the basic pattern of planning problems created by the Industrial Revolution emerged, naturally enough, when people began to be really affected by the sanitary conditions brought about by the disorder and overcrowding of new suburbs. (...)" (BENEVOLO, 1971: 89)

Ao que tudo indica, o foco nas questões da moradia teriam permanecido como discurso central dos Acts promulgados ao longo da primeira metade do século XX. O Housing, Town Planning, Etc. Act (1909), por exemplo, deu às autoridades locais a função de preparar planos urbanos para ordenamento do desenvolvimento, com o objetivo de "assegurar as condições sanitárias apropriadas, beleza e conveniência" (CULLINGWORTH\&NADIN, 2007: 17). O mesmo Ato, revisto em 1919, trouxe poucas transformações efetivas ao primeiro, sem ainda abordar a questão da circulação de maneira mais ampla.

A questão da circulação começaria a ser apontada como preocupação dos Planning Acts somente a partir de observadas algumas conseqüências adversas das ocupações baseadas no crescente uso dos automóveis. Neste sentido, o The Restriction of Ribbon Development Act de 1935, expressou uma grande preocupação com um tipo característico de expansão linear ao longo dos eixos viários. Mas para Buchanan este Ato, que previa a reserva de uma faixa para expansão da via, foi gestado independente do planejamento urbano (BUCHANAN, 1958). Esta faixa de reserva valia para a abertura de qualquer via, necessitando apenas da aprovação das autoridades de tráfego. Não se tratava, portanto, de uma de política urbana no sentido de sua integração com a circulação, mas de uma visão meramente administrativa.

O ato de 1935 foi, em grande medida, uma conseqüência do Town and Country Planning Act de 1932. No entanto, conforme Buchanan, seus objetivos eram muito mais estéticos do que garantir condições de circulação efetiva para os veículos motorizados (BUCHANAN, 1958). O foco, neste caso, pareceu mais ser o de aumentar os poderes dos organismos de planejamento para qualquer tipo uso do solo, seja ele um assentamento

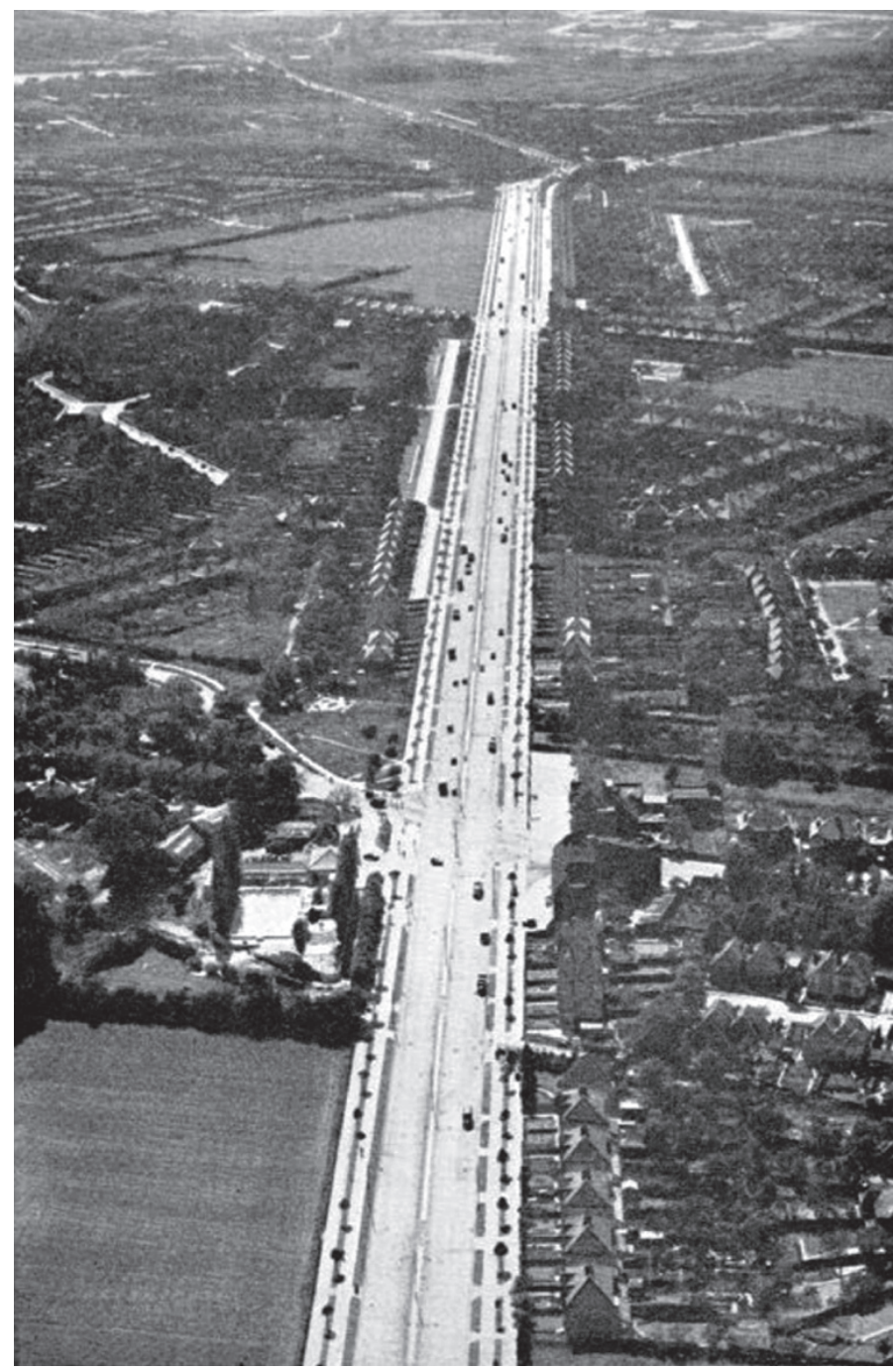

Figura 25: Aspectos da urbanização linear ao longo das vias rurais (Ribbon Development) - Great West Road, RU, 1951 Fonte: HALL, 2002: 24 
urbano ou não (CULLINGWORTH\&NADIN, 2007).

No discurso montado em Mixed Blessing, preocupava o engenheiro-urbanista britânico as conseqüências urbanas relacionadas ao aumento do número de automóveis em circulação, as quais teriam permanecido à margem de uma ação mais incisiva e acertada por parte do Estado Britânico. O primeiro tipo destas conseqüências seriam aquelas relativas ao impacto nas cidades já existentes. Para ele, o transporte motorizado aumentou a mobilidade e desvinculou a cidade da dependência locacional de portos, mercados e de estações ferroviárias, causando grandes transformações na forma das cidades. O segundo tipo de conseqüências observadas a partir do automóvel incluía as expansões urbanas, surgidas principalmente no período entre guerras. Neste sentido, Buchanan distinguia três formas principais: a urbanização linear, os assentamentos dispersos e, finalmente, o urban sprawl ou espalhamento urbano.

O primeiro teria uma forte relação com os serviços de transporte coletivo por ônibus, que conectavam duas cidades. O crescimento do volume de tráfego e a necessidade de aumento da capacidade destas vias, teriam comprometido significativamente as condições de habitação nestas situações. Enquanto na urbanização linear o fenômeno seria fundamentalmente urbano, já que seus habitantes mantinham forte relação com a cidade mais próxima, no caso dos assentamentos dispersos, a questão em jogo parecia tratar-se de uma fuga dos problemas urbanos da época. Ou seja, para Buchanan, seria um fenômeno que envolveria a escolha de outro tipo de vida.

O terceiro e último tipo foi o que prevaleceu mais enfaticamente no discurso de Colin Buchanan. Enquanto os dois primeiros mereceriam pouco destaque nos trabalhos posteriores à Mixed Blessing, o fenômeno conhecido como urban sprawl, seriam reiteradamente mencionado por ele, particularmente em Traffic in Towns. A emergência desta questão não era nova, conforme Robert Bruegmann, os anos 1920 foram marcados por uma pesada crítica ao espalhamento urbano no Reino Unido. Ressalta ainda que, entre 1921 e 1931, a população de Londres cresceu perto de 10\%, enquanto a sua área urbanizada aumentou em cerca de 200\% (BRUEGMANN, 2005). 
Ainda assim, sua maior preocupação, ao que parece, se dava não pela observação do que ocorria no seu país, mas pela comparação com o mesmo fenômeno que se apresentava em larga escala nos Estados Unidos. Para ele, o exemplo norte americano era a maior expressão da falta de articulação entre as ações de planejamento urbano e de transportes (BUCHANAN, 1963).

Já a demanda por infra-estrutura viária se deu fora deste universo da ação do Estado sobre as condições sanitárias da cidade desde o século XIX. Tratava-se da apresentação de uma demanda concreta, em que as necessidades se colocavam como o alargamento de uma determinada via ou melhoramento das condições de rodagem. Neste contexto,

“The term 'road planning' signified, and to a large extent still does today, the engineering considerations of curvature, gradient, drainage and cut and fill. The idea that a new road could have profound social implications took years to develop" (BUCHANAN, 1958: 118).

No campo dos Traffic Acts, as primeiras ações do Estado Britânico no sentido de uma maior preocupação com construção e manutenção da infra-estrutura viária remontam à meados do século XIX. Inicialmente, por meio do Highway Act de 1862, ficou estabelecido que eram as unidades locais de governo que deveriam se responsabilizar pela construção e manutenção do sistema viário.

O governo Britânico agiria outra vez neste sentido no início do século XX, com o The Development and Road Improvement Act, de 1909 e a conseqüente criação da Road Board e do Road Improvement Fund em 1910. Este parece ter sido, como o próprio Buchanan admitiu em Mixed Blessing, o primeiro reconhecimento oficial da necessidade de adaptação da infra-estrutura viária para o automóvel (BUCHANAN, 1958).

Harry Dupree (1987) vê este período numa perspectiva um tanto quanto pessimista. Para ele, embora tivesse a seu favor as receitas advindas da recém criada taxação dos veículos motorizados, além da coordenação de mais de dois mil escritórios locais, as

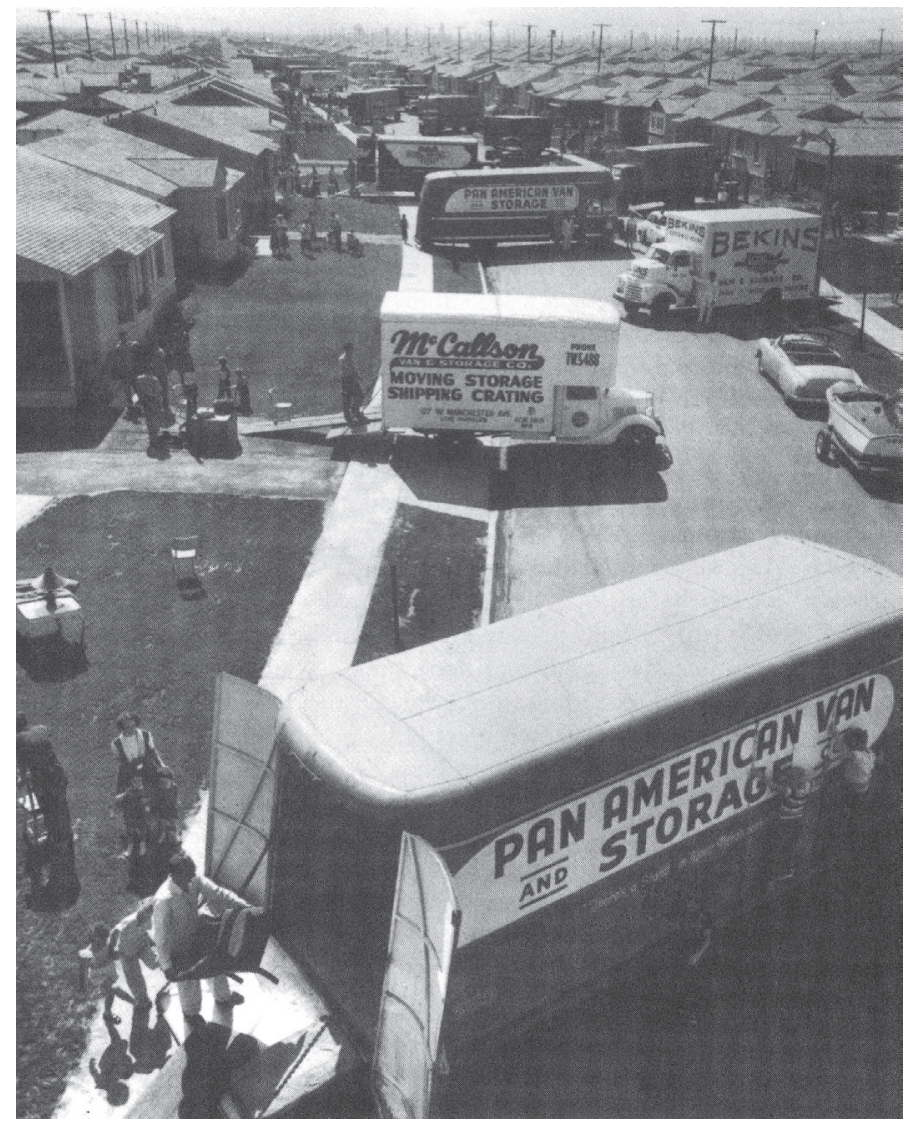

Figura 26: Jovens famílias em mudança para um subúrbio norte-americano logo após a II Guerra Mundial Fonte: SOUTHWORTH; BEN-JOSEPH, 1997: 87 
atividades do Road Board não decolaram; muito em razão das dificuldades econômicas advindas com a I Guerra Mundial. Assim, neste cenário, ainda que o número de veículos viesse aumentando, os movimentos do governo britânico no sentido da melhoria da qualidade da infra-estrutura viária pareciam ainda acanhados em relação ao crescimento da demanda.

Conforme Dupree, não havia arcabouço legal suficientemente forte para dar suporte à construção de vias no período entre guerras. As tímidas iniciativas de construção viária foram acompanhadas de desenvolvimentos urbanos considerados inadequados.

“(...) The roads encouraged the indiscriminate opening up of adjoining land for building development and, worse still, sometimes the establishment of ribbon developments of houses, factories, shops and public houses alongside the roads themselves. It was a planning disaster." (DUPREE, 1987: 13)

Colin Buchanan, entretanto, apresenta uma visão um pouco mais otimista deste período. Para ele, neste período, Traffic Act de 1930 deu instrumentos para adequação viária sem precedentes no Reino Unido, particularmente influindo na velocidade de projeto. Conforme Buchanan (1958), nunca houve propriamente um surto de construção de vias na Inglaterra, mas em 1930 um movimento mais intenso neste sentido chegou quase a acontecer. A partir deste Traffic Act várias vias foram adequadas às novas condições de circulação veicular, sobretudo o aumento da velocidade. Curiosamente, logo na seqüência, o Road Traffic Act de 1934 estabeleceu o limite de $30 \mathrm{mph}(48 \mathrm{~km} / \mathrm{h})$ em toda malha urbana. Naquele momento esta medida foi considerada uma panacéia para solução dos problemas dos acidentes, que vinham apresentando taxas crescentes ${ }^{19}$.

Ainda assim, segundo ele, os sucessivos Traffic Acts não passavam de paliativos ao verdadeiro problema que emergia:

19 Vale lembrar que o livro de Alker Tripp é de quatro anos mais tarde e é fortemente calcado na questão da segurança de tráfego (TRIPP H. Alker. Town Planning and Road Traffic. London, Edward Arnold, 1942 (1938)) 
“(...) Speaking in the broadest terms, all that has been done to our road system since the coaching days to adapt it for motor traffic has been to provide smooth, all-weather, dustfree surfaces. The motor vehicle has had to develop within the limitations of this system of narrow sinuous tracks and it is difficult to see any further significant changes can take place in vehicle design unless the track system is developed also. (...) In the towns, the street and building arrangements are so overwhelmed by traffic that motor is in danger of losing its utility. There is nothing more we can extract from it unless we alter the physical arrangements, which may involve us (...) in a frank balancing of the advantages of motor transport against the merits of our towns as they exist". (BUCHANAN, 1958: 18-19)

Conforme Buchanan (1958), a questão da circulação urbana só seria enfrentada com mais clareza anos mais tarde, com a promulgação do Town and Country Planning Act de 1947. Mesmo assim, para ele, a abordagem desta questão teria ainda um longo caminho a percorrer:

“(...) It might be thought that the planning and building of roads was obviously part and parcel of the planning of towns, but the fact is that even today when planning has in theory extended its activities to the control of all development in both town and country, the two processes have not been brought completely together" (BUCHANAN, 1958: 117)

A afirmação de Buchanan, ressaltando ainda a dificuldade de integração entre as esferas de planejamento, não deixa de ser curiosa, em especial se considerado o período do segundo pós guerra. Neste momento, o debate sobre urbanismo parece apontar para a plena incorporação desta questão, ao contrário do que ele afirmava.

Pelo menos desde o Plano para Londres, elaborado por Pattrick Abercrombie e J. H. Forshaw em 1943, as questões de circulação e arranjo das funções urbanas vinham sendo tratadas de forma conjunta. Antes mesmo, a literatura internacional esteve repleta de exemplos neste sentido, desde os trabalhos de Eugene Henard na França da virada do século XIX para o século XX, passando por Le Corbusier no período entre guerras, até o estudo teórico apresentado pela equipe Britânica dos CIAM's, Modern 
Architecture Research Group (MARS - 1938-42)

Contemporaneamente à Colin Buchanan, dois grande clássicos da literatura de urbanismo Britânica já haviam resolvido plenamente esta dupla abordagem, apontando a necessidade de integração entre o tráfego e uso do solo. Tanto o livro de Lewis Keeble, publicado inicialmente em $1952^{20}$, quanto o de Frederick Gibberd, publicado pela primeira vez em $1953^{21}$, contemplavam esta questão e apareceram com referências na obra do engenheiro-urbanista. Além destes, o influente periódico Town and Country Planning Review publicou diversos artigos discutindo o tema, pelo menos desde meados dos anos 195022. Em resumo, os exemplos vistos no capítulo anterior não deixam dúvidas da discussão que havia naquele momento.

No campo da prática profissional, as realizações das New Towns, em curso a partir de meados dos anos 1940, já haviam produzido um amplo debate urbanístico e certamente colocaram a questão da circulação nas cidades, articulada ao planejamento urbano. $\mathrm{Na}$ segunda fase de construção das Novas Cidades britânicas (Mark II) a questão dos transportes, de uma maneira geral, havia assumido o papel de protagonista.

A desconsideração em relação a todo este debate não deixa de ser bastante instigante. Neste cenário, fica evidente que o discurso de Colin Buchanan da lacuna histórica entre planejamento urbano e tráfego tinha outras intenções e que tal esforço não era particularmente focado numa possível contribuição à história do urbanismo.

Conforme Taylor (2008), a produção e o debate de urbanismo do segundo pós guerra no Reino Unido havia sido marcado pela ideologia do planejamento urbano situado na esfera da técnica. Ainda segundo o autor, personagens importantes desta história como Thomas Sharp, Patrick Abercrombie, Lewis Keeble e Frederick Giberd foram grandes entusiastas desta visão.

20 KEEBLE, L. Principles and Pactice of Town and Country Planning. Londres, The Estates Gazette Ltd, 1961 (1952

21 GIBBERD, F. Town Design. Londres, The Architectural Press, 1962 (1953)

22 A este respeito ver Aucott (1960), Bill (1955), TCPR (1957) e Moak (1956) 
Ao reconstruir este caminho a partir dos Acts do governo Britânico e não do cenário urbanístico, Buchanan procurava situar o problema da lacuna entre planejamento urbano e tráfego de automóveis, apontado por ele, na esfera das políticas públicas. Sua experiência como funcionário público desde os anos 1930, parece ter lhe conferido uma dimensão operacional deste problema no âmbito político.

Neste sentido, é reveladora a resposta de Buchanan a um editorial publicado pela revista Traffic Engineering and Control em 1964. Para a revista, o relatório Traffic in Towns teria se dedicado pouco às questões da engenharia, ao tratar do problema do tráfego urbano. Respondendo a estes argumentos, Buchanan alegou que o relatório não se debruçava sobre a engenharia de tráfego tradicional, que por ser ciência tinha pouco a se discutir, mas sobre o gerenciamento de tráfego, que seria uma questão situada no âmbito das políticas públicas (BUCHANAN, 1964). Era este também um dos principais pontos de discordância em relação à engenharia de tráfego norte-americana.

Portanto, para ele, esta lacuna apresentava uma dimensão que ia além das propostas formais no campo do urbanismo e dos avanços técnicos proporcionados pela engenharia de tráfego, mas continha um componente fundamental que se situava na revisão do modelo institucional de gerenciamento do planejamento britânico.

Não por acaso, um dos importantes encaminhamentos do relatório Traffic in Towns, curiosamente não mencionado na literatura, é a proposição de uma agência para tratamento da questão conjunta dos transportes e do planejamento urbano, nos moldes daquela montada por ocasião do New Towns Act. Esta proposta foi defendida no relatório do Grupo Diretivo, pelo seu presidente Geoffrey Crowther (BUCHANAN, 1964a).

A proposta de criação de uma agência, numa situação de planejamento urbano institucionalizado como no caso britânico, não deixa de ser inusitada. Ao que parece, esta proposta do relatório Traffic in Towns apontava também para a construção de um novo campo ação do planejamento urbano, que poderíamos denominar como "planejamento da mobilidade urbana". 


\section{capítulo 4}

\section{O fenômeno da circulação urbana}

A discussão empreendida por Colin Buchanan sobre o tráfego e a cidade passa por um intenso esforço de formulação teórica sobre a natureza do fenômeno da circulação de veículos no meio urbano e de suas conseqüências a partir do aumento da frota de automóveis.

Neste sentido, a obra de Buchanan sugere a conformação de questões estratégicas para a viabilização de sua aposta no automóvel. Trata-se, para ele, de um fenômeno urbano e, como tal, deve ser compreendido à luz de considerações sobre sua natureza e de sua relação com as questões urbanas, que se processam de maneira indissociada. Assim, Buchanan desloca o foco dos critérios de desempenho, como faziam seus colegas norteamericanos, para o conflito entre cidade e tráfego.

Em paralelo, se contrapõe ao discurso urbanístico recorrente naquele momento sobre a importância do tráfego de passagem. O seu principal foco neste caso se concentra na desconstrução do modelo radio-concêntrico. Ainda que sua experiência a partir de Traffic in Towns e de seus trabalhos como consultor indiquem que esta questão parece bem mais complexa que inicialmente imaginava, tal discurso aponta para a inviabilidade do modelo radio-concêntrico, no contexto do automóvel. Esta questão se apresenta com contornos mais nítidos no Estudo para South Hampshire (1966). 
Finalmente, a obra do engenheiro-urbanista britânico se mostra bastante sensível à viabilização do automóvel nos centros das cidades. Trata-se, acreditamos, de uma questão essencial para a política de deslocamentos que Buchanan constrói, baseada prioritariamente em um único modal.

\section{O conflito entre tráfego e cidade}

Colin Buchanan entendia o fenômeno do tráfego urbano a partir de um conjunto de conflitos. Já em Mixed Blessing o autor identificou esta questão com um título bastante sugestivo: Clash and Friction ou Choque e Atrito. A visão do problema do automóvel na cidade e sua relação de atrito com o tecido urbano não era propriamente inédita. O livro de Robert Mitchell e Chester Rapkin, "Urban traffic: a function of land use", publicado em 1954 nos Estados Unidos, já havia se debruçado sobre este aspecto ${ }^{23}$ :

"A local transportation system, including its highway network, is essentially a service system, the function of which is to expedite the "friction of space". (MITCHEL; RAPKIN, 1954: 5)

No entanto, embora Buchanan recorresse a esta referência, para ele a questão fundamental não seria somente a de minimizar o "atrito" com o espaço urbano, para permitir o bom funcionamento do "serviço" de circulação, como admitiam Mitchel e Rapkin. De fato, o engenheiro-urbanista britânico parecia também preocupado em compreender melhor o espaço urbano e os efeitos adversos do tráfego veicular:

“(...) Finally there is the abrasive friction of motor traffic which in various ways direct and indirect is steadily grinding away all the amenity and pleasantness of our roads, and, which is perhaps worse, of the adjoining lands" (BUCHANAN, 1958: 82)

23 Os autores eram pesquisadores do Institute for Urban Land Use and Housing Studies da Universidade de Columbia e o livro mencionado pode ser considerado um trabalho pioneiro neste campo. 
Segundo os pesquisadores norte-americanos a natureza e a localização das atividades urbanas se alteravam constantemente, enquanto a infra-estrutura urbana de transportes seria caracterizada pela sua dificuldade de se modificar, além de seu elevado custo. Sua obsolescência seria o fator mais importante de congestionamento. Esta constatação levaria a um importante desafio ao planejamento de transportes: como conseguir o melhor rendimento de capital nas grandes artérias e outros canais de tráfego, projetando-os de forma a responder às demandas atuais e futuras. (MITCHELL; RAPKIN, 1954)

Esta abordagem parecia mais relacionada aos custos de transporte e da localização, numa direção teórica que procura desvendar a lógica das localizações comerciais. Neste sentido, o espaço poderia ser considerado um input quando relacionado às questões de custos, mas visto ainda como um output já que as empresas venderiam também a comodidade da localização na cidade (MITCHELL; RAPKIN: 1954).

Embora partindo da mesma constatação do atrito entre cidade e tráfego, Buchanan parecia menos preocupado com a questão econômica por trás da lógica de localização das atividades urbanas. Para ele, o sentido deste conceito residia mais na solução do problema de convivência pacífica dos assentamentos urbanos com a circulação dos modos motorizados.

A convivência pressupunha compartilhamento dos mesmos espaços urbanos. As formas deste convívio se tornaram então um foco de sua preocupação. Existia para Buchanan uma série de problemas associados ao compartilhamento de espaços entre os automóveis e a cidade.

Buchanan foi um dos pioneiros na consideração dos efeitos adversos do tráfego, no que diz respeito aos impactos da poluição gerada pelos veículos de uma forma geral, mas mais particularmente os caminhões. Segundo ele, enquanto outras externalidades, como os acidentes, já haviam sido motivo de bastante repercussão, a deterioração do espaço urbano sob efeito do crescimento do tráfego pesado era ainda pouco noticiada. 
Com este propósito, utilizou-se de um relatório produzido pelo governo britânico em 1963, que apontava o ruído de tráfego como a fonte predominante de incômodos aos habitantes. Tal relatório, após avaliar as principais fontes de ruído sugeria entre outras medidas a redução do volume de tráfego, como forma de diminuir os indicadores de desconforto acústico (BUCHANAN, 1963).

Se de um lado seu discurso apoiava-se na inevitabilidade do transporte por automóveis, por outro, cada vez mais, medidas restritivas ao seu uso tomam corpo no seu discurso. Assim, o discurso de Buchanan buscava apoio em dados objetivos que sustentassem a necessidade de controle do uso do automóvel. Controlar o volume de tráfego pelo nível de ruído gerado tinha a vantagem de se constituir em algo parametrizável, passível de se mensurar facilmente por meio de um indicador. Valores relativos à poluição do ar ainda eram pouco difundidos no Reino Unido naquele momento, assim como seria difícil tornar objetiva a avaliação da poluição visual.

Além da poluição, a questão da viabilidade física da convivência entre veículos e pedestres era especialmente importante. Esta visão da disputa física de espaço vinha declaradamente de Alker Tripp, que já em 1938 havia colocado os problemas associados à circulação compartilhada de pedestres, ciclistas e veículos. Para ele, tratava-se de uma questão de definitiva incompatibilidade entre velocidades e energias de deslocamento.

"The broad facts of the position are clear. These casualties are caused by unexpected encounters with fast road traffic. Fast road traffic is a fact which no amount of argument on the pedestrian's part can obviate. If an unexpected encounter occurs between a pedestrian and a fast-moving vehicle, it is the pedestrian who suffers; often he is killed outright (...)". (TRIPP, 1950: 132)

Buchanan recuperava o discurso de Tripp, afirmando:

“(...) Of the many unhappy frictions now developing, the worst is the conflict between human beings and heavy moving vehicles." (BUCHANAN, 1958: 190)

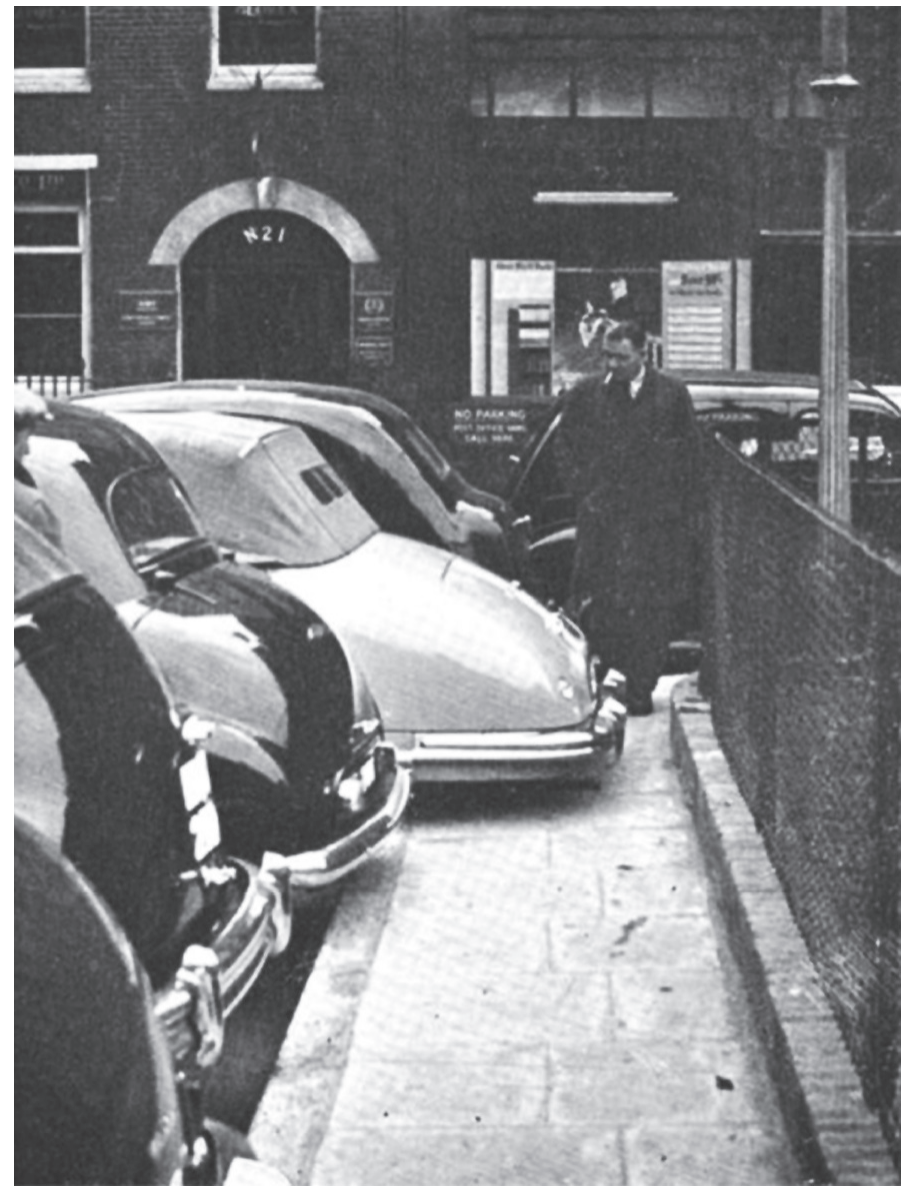

Figura 27: Pedestre disputa espaço com um automóvel em uma calçada na Inglaterra Fonte: BUCHANAN, 1958: 89 
E foi ancorado neste raciocínio que em Mixed Blessing, Buchanan anunciou uma proposta que seria bastante desenvolvida no relatório Traffic in Towns: a separação de tais conflitos em planos diferentes de "solo" urbano. Diante da impossibilidade de compartilhamento do pouco espaço urbano existente, era necessário que os automóveis e as funções ligadas aos pedestres estivessem separadas por planos em cotas diferentes.

Neste aspecto, Buchanan estabelece uma forte contraposição ao discurso de Jane Jacobs. Com um texto de nome sugestivo, "Do not segregate pedestrians and automobiles", a autora faz uma pesada crítica aos projetos contemporâneos que compartilhavam a mesma visão de Buchanan, argumentando que:

"I suggest that the way out is (...) to admit that we are not yet ready for gransiose or very radical schemes for rescuing city pedestrians. We have not done our homework. To do it, and simultaneously accomplish something, we should start quite humbly. We should start simply by giving direct, very functional and obvius consideration to pedestrians. And this should be done in precisely the places where pedestrians already appear in large numbers in spite of the inconveniences they meet and the impositions to which they are subjected (...) (JACOBS, 1966: 110)

Para ela, os conflitos tão temidos por Buchanan eram parte da realidade cotidiana dos pedestres e, no final das contas, da própria dinâmica urbana. A separação proposta ia de encontro à natureza da convivência urbana de diversos conflitos, já que admitia que o principal deles não poderia mais se dar diante da nova etapa de motorização da sociedade.

As externalidades geradas pelo tráfego tinham um desdobramento no seu próprio desempenho, segundo Colin Buchanan. O automóvel, como modo de transporte, apresentava enormes potencialidades, mas estas eram prejudicadas pelo "atrito" com o tecido urbano e com o próprio volume de tráfego.

"The characteristic which distinguishes the motor vehicle form other forms of mechanical is its ability ro provide a door-to-door service. This is being frustrated partly by the multipli- 
cation of the vehicle's own numbers, and partly by the form and arrangement of towns. (...) The freedom with which, only a few years ago, one could stoop outside a shop and go in for some simple purchase, is now a thing of the past (...)" (BUCHANAN, 1963: 14)

Para seu melhor desempenho, o carro deveria ter a possibilidade de utilizar todo seu potencial de velocidade sem as impedâncias que vinham sendo impostas, como o congestionamento. Ao mesmo tempo, era também necessário encontrar locais disponíveis para estacionamento próximos aos seus destinos finais.

Baseado em todas estas considerações, Colin Buchanan formula o seu conceito de conflito entre cidade e tráfego. Na opinião dele, tratava-se de um delicado equilíbrio entre environment e accessibility. Embora tenha sido formulada para Traffic in Towns, uma definição mais clara aparece no relatório para "Cardiff-Development and Transportation Study":

“(...) These terms are used in a special sense. 'Environment' is concerned with the maintence of acceptable standardas in relation to freedom form danger, noise, fumes, vibration and visual intrusion of motor vehicles. 'Accessibility' is concerned with the freedom for vehicles to move easily from one part of the city to another, to penetrate to destination and stop there on arrival" (COLIN BUCHANAN \& PARTNERS, 1966: 5)

É possível afirmar que havia neste raciocínio uma oposição entre áreas de serviço (accessibility) e áreas servidas (environment). Neste sentido, o idéario de Radburn parece ter sido uma referência fundamental na definição do conflito entre ambiente e acessibilidade: "Considered to be efficient for the 'motor age', the idea was based on functional separation: vehicles from pedestrian, service from living" (MADANI-POUR, 1992: 10). Se a experiência de Radburn resolvia o conflito nas áreas de expansão habitacional, Buchanan estenderia o conceito para a escala da cidade.

"Ambiente" e "Acessibilidade" tornaram-se para Buchanan a expressão de um conflito permanente, gerado a partir do automóvel. Neste sentido, o engenheiro-urbanista britânico estabeleceu um novo referencial para a discussão do tráfego nas cidades. Enquanto 
para a engenharia americana o conflito se dava entre a fluidez e segurança, para Colin Buchanan o conflito se dava entre acessibilidade e cidade (VASCONCELOS, 1996).

Em outras palavras, tratar somente do conflito entre fluidez e segurança, apresentava o problema de desconsiderar o meio na qual todos os movimentos motorizados se processavam. Este meio, como Buchanan admitiu, não era inerte, mas apresentava uma série de reações ao movimento, era influenciado e influenciava o tráfego.

\section{A circulação motorizada como fenômeno urbano}

Se a oposição de fato se dava entre acessibilidade e cidade, e não somente entre fluidez e segurança, era necessário então compreender as características dos movimentos que compunham o tráfego urbano. O carro, como modo de transporte, apresentava um grande potencial na visão de Buchanan, mas para utilizar todo este potencial disponível era preciso compreender a fundo as características daquilo que chamou de "acessibilidade".

Para Buchanan, "vehicles do not of course move about the roads for mysterious reasons of their own" (BUCHANAN, 1963: 33). Havia neste fato uma motivação gerada pela necessidade de realizar determinadas atividades humanas. Ou seja, o tráfego era considerado uma função das atividades que se processavam naturalmente nas cidades.

Neste aspecto, as discussões empreendidas por Buchanan dialogavam diretamente com o trabalho de Robert Mitchell e Chester Rapkin (MITCHELL; RAPKIN, 1954). A obra consta da bibliografia dos dois trabalhos onde o engenheiro-urbanista britânico discutiu mais detalhadamente a questão do fenômeno da circulação urbana: Mixed Blessing (1958) e Traffic in Towns (1963).

A aparentemente simples constatação do tráfego como função urbana parece ser o ponto de partida de uma série de considerações elaboradas por Buchanan para a compre- 
ensão da circulação nas cidades. Para ele, a questão da expansão da frota de veículos e seu impacto tinham a cidade como lugar de ocorrência, já que esta era o foco da grande maioria das atividades humanas. Assim, os assentamentos dispersos não seriam objetos de suas maiores atenções e o "modelo Radburn", como veremos adiante, poderia ser considerado uma solução satisfatória para a questão.

Ao contrário de Mitchell e Rapkin (1954), que consideravam as cidades como grandes terminais de viagens, para o engenheiro-urbanista britânico as cidades eram não somente os locais de ocorrência dos problemas de tráfego, mas, sobretudo as principais produtoras de viagens não só externas, mas principalmente internas. No caso britânico, era, portanto, a dinâmica interna do movimento urbano a principal fonte dos congestionamentos.

De fato, as maiores preocupações do Mitchel e Rapkin (1954) parecem residir no modelo americano de urbanização - o sprawl, enquanto Buchanan pensava na situação de seu país, com suas principais cidades marcadas pela ocupação densa e de tecido antigo. Viabilizar a circulação nas cidades era viabilizar a presença do automóvel na sociedade da época.

A este respeito, Geoffrey Crowther, presidente do Grupo Diretivo de Traffic in Towns, ressaltava:

“(...) the American policy of providing motorways for commuters can succeed, even in American conditions, only if there is a disregard for all considerations other than the free flow of traffic which seems sometimes to be almost ruthless. Our British cities are not only packed with buildings, they are also packed with history, and to drive motorways through them on the American scale would inevitably destroy much that ought to be preserved" (BUCHANAN, 1963: \22).

Antes de tudo, era necessário entender a natureza do tráfego urbano para depois formular estratégias para organizá-lo; e Buchanan formulou esta compreensão por meio 
de três questões principais: a definição dos tipos de movimento motorizado urbano, a distinção do tráfego entre essencial e opcional e a desconstrução do discurso sobre o tráfego de passagem e suas conseqüências para as cidades.

Em Traffic in Towns, os usos do solo foram organizados conforme as seguintes categorias: 1) indústrias, 2) armazéns e centros de distribuição, 3) comércio, 4) escritórios e edifícios públicos, 5) escolas e 6) habitações e moradias. Estes usos ensejariam quatro tipos de movimentos principais: 1) transportes de mercadorias, 2) transporte de passageiros em grande escala, 3) transportes individuais e, finalmente 4) serviços móveis, como veículos de emergência e entregas (BUCHANAN, 1963)

Os quatro movimentos principais destacados resultariam numa distribuição desproporcional dos desejos de viagem. Baseado na sua experiência pessoal, argumentava que a seguinte distribuição seria bastante comum: radial com $45 \%$, perimetral com $5 \%$ e, finalmente, o que ele denominou tráfego disperso com $50 \%$. Estes três tipos apareceriam em maior ou menor grau em todas as cidades. (BUCHANAN, 1958)

Para ele o principal problema seria o tráfego disperso. Composto por uma massa de deslocamentos de pequena distância e realizados em todas as direções, estes seriam impossíveis de se canalizar.

"Although very little research has been done on the nature of urban motor journeying, and figures are woefully lacking, it seems fairly clear that congestion is the product of large numbers of vehicles making highly complex radial, scatter, and cross journeys through narrow streets. With vehicles desiring to move in so many directions it is obvious that particular trouble is likely to arise at intersections which are the only points where vehicles can change direction. (...) This picture of urban traffic circulation, of large numbers of vehicles drawing an infinitely complex pattern of criss-cross journeys in every direction, is considerably different from the notion that seems to have dominated planning thought up to present. All the emphasis so far has been on through-traffic (...)

(BUCHANAN, 1958, 189). 
Novamente, esta noção era tributária dos conceitos difundidos por Robert Mitchell e Chester Rapkin, que classificavam as formas de movimento urbano em três tipos. Os movimentos de captação, em que pessoas ou cargas concentram-se em determinados lugares, como as áreas centrais ou os grandes armazéns; os movimentos de dispersão, que teriam natureza inversa do primeiro, estando associados aos destinos finais, como áreas residenciais e comércios locais; e, finalmente, os movimentos aleatórios. Estes últimos, tomados individualmente, poderiam estar contidos nas duas primeiras categorias e seriam insignificantes quanto considerados por zonas de tráfego; no entanto, quando vislumbrados em seu conjunto, teriam participação significativa no conjunto dos deslocamentos urbanos (MITCHELL; RAPKIN: 1954).

Curiosamente, Buchanan optou pela definição dos pesquisadores norte-americanos e não pelo estudo para Londres, elaborado por seus conterrâneos do grupo MARS (Modern Architecture Research Group-MARS - 1938-42). Para eles, o transporte de passageiros poderia ser dividido em quatro categorias: 1) tráfego pendular $(60 \%) ; 2)$ tráfego pontual (shows, teatro, etc) (12\%); 3) tráfego circular (vendedores) (20\%); 4) tráfego local (8\%).

O tráfego pendular seria o mais importante e precisaria ser o mais rápido e simples possível. A ele estariam associados os chamados modos "organizados", que normalmente estariam mais vinculados aos modos sobre trilhos. O outro elemento seria o transporte "flexível", mais indicado para distâncias curtas e associado aos automóveis, ao contrário do primeiro mais indicado para longas distâncias.

Assim, a conclusão apresentada pelo plano desenvolvido pelo grupo MARS indicava naturalmente uma opção pelos modos públicos, divergindo radicalmente da avaliação de Buchanan. Os primeiros chegaram a admitir que uma boa organização dos transportes públicos eliminaria a necessidade dos automóveis.

Estando Buchanan bastante sintonizado com o debate urbanístico, sobretudo o britânico, a ausência de qualquer referência deste plano em seus trabalhos não pode ser considerada um mero caso de desconhecimento.

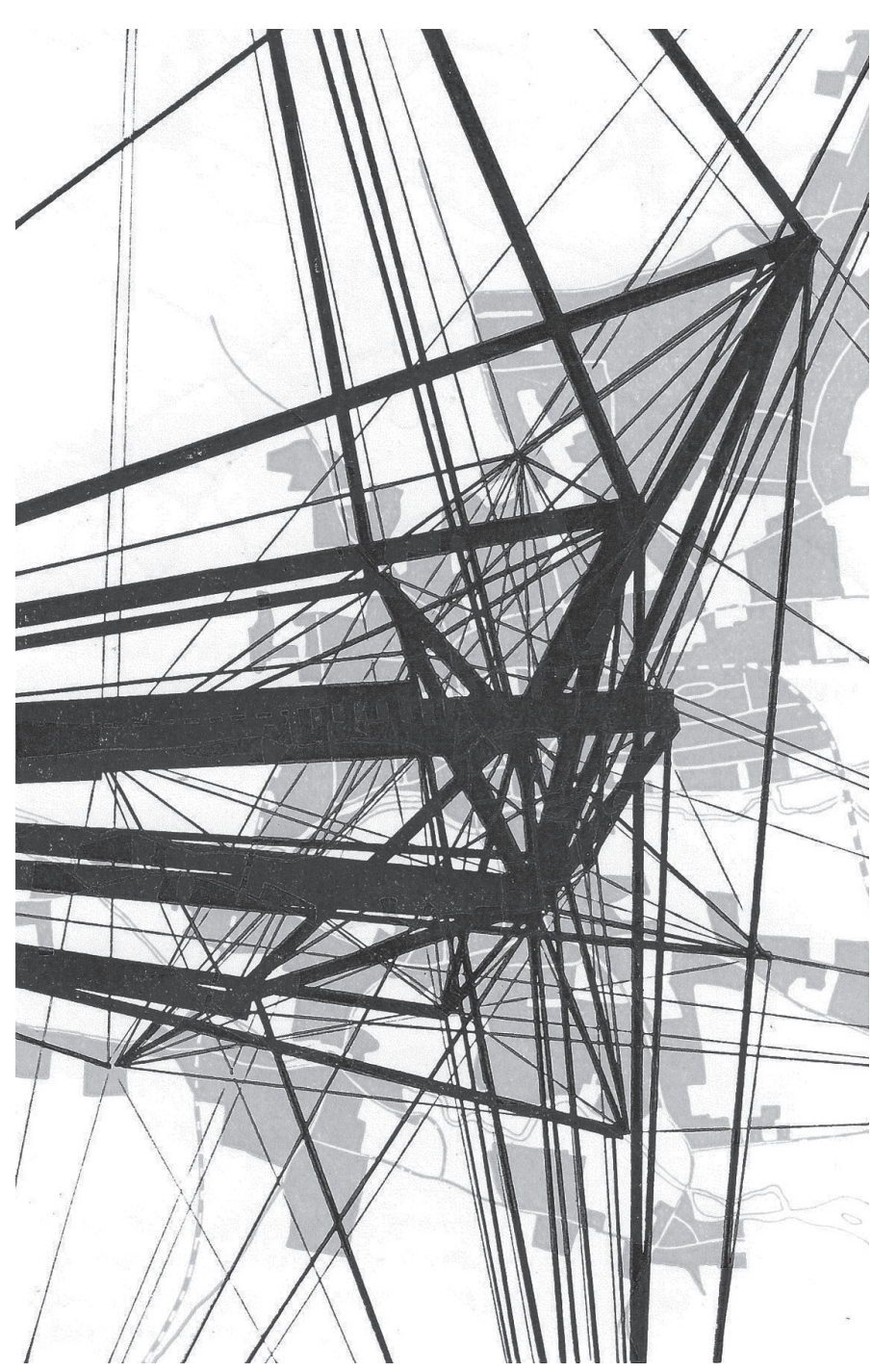

Figura 28: Traffic in Towns: diagrama de Desejos de Viagens para uma cidade pequena Fonte: BUCHANAN, 1963: 36 
Podemos afirmar que os movimentos aleatórios ou as viagens dispersas, como denominou Buchanan, nada mais são que uma característica intrínseca do automóvel como modo de transporte. Sua natureza individualizada permite que as viagens sejam encadeadas de maneira imponderável, não só dependendo da distribuição dos usos, mas agindo diretamente sobre a organização deles. Em outras palavras, mesmo sem que Buchanan tivesse admitido textualmente, o engenheiro parecia afirmar que os movimentos aleatórios seriam uma conseqüência inevitável da cidade na era do automóvel.

Se os movimentos aleatórios eram oriundos da própria essência do automóvel como modo de transporte, tratava-se, portanto, de encontrar outra forma de distinguir os movimentos motorizados na cidade; algo que abrisse a possibilidade de alguma restrição de uso. De fato, Buchanan reconheceu diversas vezes a impossibilidade de assimilar todos os deslocamentos por automóveis simultaneamente.

Com esta finalidade Buchanan propõe então o conceito de tráfego essencial e opcional. O primeiro estaria ligado a propósitos considerados essenciais para as atividades urbanas, como negócios, comércio e indústria; enquanto o segundo se associaria à condicionantes de conveniência e lazer.

Beesley e Kain (1968), no entanto, criticam a divisão entre tráfego essencial e opcional. Os autores discordam da estratégia de limitação do volume veicular, a partir do emprego da noção de tráfego opcional, proposto em Traffic in Towns. Neste sentido, os autores indicam que, no próprio Report, a aplicação dos conceitos apresentam alguns pontos conflitantes. No estudo para Leeds, por exemplo, as viagens por ônibus por motivos de compras eram consideradas "não essenciais". Segundo os autores:

"Hay dos problemas básicos: cuál es la lógica em esta 'simple’ distinción de gran importancia entre 'essencial' y 'opcional'; y si puede surgir de ella um medio operativo para asegurar la restrición del tráfico” (BEESLEY; KAIN, 1968: 114)

Até mesmo Geoffrey Crowther (Presidente do Grupo Diretivo dos trabalhos de Traffic 
in Towns) relativizou este conceito, chamando atenção para sua dificuldade de implantação (BUCHANAN, 1963). De fato, não havia condições operativas de implantar uma medida como esta. A distinção principal, ao que parece, estaria não no propósito da viagem, mas sim no modo pela qual ela é realizada. Neste sentido, Beesley e Kain (1968) criticam a ausência de ponderações mais construtivas, como até que ponto viagens como estas podem ter um modo substituto imediato ou formas diferentes de viagens (como não ir ao centro em determinados horários).

Entretanto, não se trata somente de uma fragilidade do método. Considerando a construção do discurso de defesa do automóvel que Buchanan realizou em diversas ocasiões, a questão da opção por modos alternativos para os deslocamentos urbanos não estava efetivamente em debate. Diante da "encomenda", Buchanan parecia focado viabilidade do automóvel.

Sua análise sobre o futuro dos veículos motorizados em Traffic in Towns foi rápida e burocrática, comentando rapidamente algumas possibilidades discutidas na época, entre elas uma alternativa de propulsão individual a jato. Estas considerações, ao final, foram empregadas como forma de justificar o foco no automóvel:

"Our conclusion, therefore, is that the future of the motor vehicle, or some equivalent machine, is assured. We think it follows that a close, constructive examination must be made of towns and cities in order to see how the best use of the motor vehicle can be achieved in those places, and how the present dificults can be overcome. This presents the basic standpoint of our study. We accept the motor vehicle as a potentially highly beneficial invention (...)”. (BUCHANAN, 1963: 25) (grifo nosso)

Ao mesmo tempo, esta tentativa de estabelecimento de critérios para restrição do tráfego não pode ser desvinculada dos estudos levados a cabo pelo Smeed Report, que entre 1962 e 1964 estava debruçado em alternativas para implantação de uma política de taxação pelo uso de vias, algo que seria viabilizado somente muitos anos mais tarde em Londres. 
Restava então investigar melhor o discurso sobre o tráfego de passagem, uma espécie de "fantasma" no meio técnico da época. Creditava-se a este tipo de movimento a maior responsabilidade pelos congestionamentos observados nas cidades britânicas. Conforme o engenheiro-urbanista, tratava-se de algo muito mais baseado numa intuição equivocada, que propriamente em pesquisas ou dados objetivos sobre a distribuição do tráfego.

Para Buchanan, não era apenas de uma questão de atraso das viagens, causado simplesmente pelo excesso de veículos, mas sim de uma expressão de uma cidade congestionada em sua mobilidade, ou de uma espécie de entupimento, como ele preferiu afirmar: tratava-se do "general clogging up of the whole civilized functioning of town centres" (BUCHANAN, 1958: 90). De fato, o que ele pretendia demonstrar era que os atrasos eram em sua maior parte decorrência dos inúmeros conflitos no uso do espaço urbano. Assim, um motorista em seu veículo acessando ao centro, era obrigado a passar por uma série de impedâncias ao longo do seu caminho: travessias de pedestres, interseções, manobras de outros veículos para estacionamento, entre tantas outras.

Por isso, embora estivesse presente, o principal desafio não era de natureza construtiva ou de normatização de projeto, como entendiam pelo menos uma parte de seus colegas norte-americanos, mas de configuração urbana. Para ele, a circulação regional em rodovias ou vias expressas já havia sido suficientemente estudada nos Estados Unidos e havia também bons exemplos na Alemanha, que ele visitara poucos anos antes. Tratavase apenas de explorar as potencialidades dos veículos quanto à velocidade e segurança, já que não estavam presentes os conflitos característicos das áreas urbanas.

Buchanan deslocava o problema como questão de engenharia exclusivamente e o trazia para as cidades, conforme já comentamos. Era necessário então investigar a natureza dos deslocamentos motorizados. Neste sentido, o engenheiro-urbanista recorria novamente aos estudos pioneiros de Mitchel e Rapkin nos Estados Unidos:

"From the point of view of between-city or into-city traffic, the entire urban me- 
tropolitan network is a terminal system that collects and distributes the long distance traffic and provides it with terminal facilities. Within large cities the other function of the urban highway network- facilitating movement among parts of the metropolitan area itself - is much more important because of the volume of traffic. In urban highway planning, therefore, the needs of both kinds of traffic must be taken into account". (MITCHEL.; RAPKIN, 1954: 5)

A cidade, neste discurso, era concebida como um grande "terminal" de viagens, na qual os deslocamentos deveriam ser gerenciados do melhor modo possível. A inclusão do tráfego regional (between-city), não deixa de ser uma característica norte-americana por excelência.

As considerações de Buchanan a este respeito pareciam não deixar dúvidas quanto à leitura atenta do trabalho dos pesquisadores norte-americanos:

“(...) In the transit or through-traffic condition the vehicle is moving deliberately from one destination to another, and for full exploitation of its characteristics it requires an open road free from obstruction by standing vehicles, intersections, crossing pedestrians, swerving cyclists, severe gradients or sharp curves. Only in such conditions can the motor vehicle really show its paces. In circulation the vehicle is casting around close to its destination, or calling at one destination after another in rapid succession. In this condition its main requirement is to be able to stop freely and easily for picking up or setting down passengers or goods, and it requires a network of roads and surfaces enabling it to penetrate to buildings of every kind, and to wait there for longer or shorter periods."(BUCHANAN, 1958: 139)

Se, de fato, há uma evidente aproximação teórica nos dois textos, as análises que surgem como conseqüência desta distinção dos tipos de tráfego se mostram distintas. Nos trabalhos de Buchanan a categoria "tráfego entre cidades" foi substituída por "tráfego de passagem", numa clara ênfase à dimensão urbana do problema, ao mesmo tempo em que praticamente foi desconsiderada a dimensão regional da circulação; que para

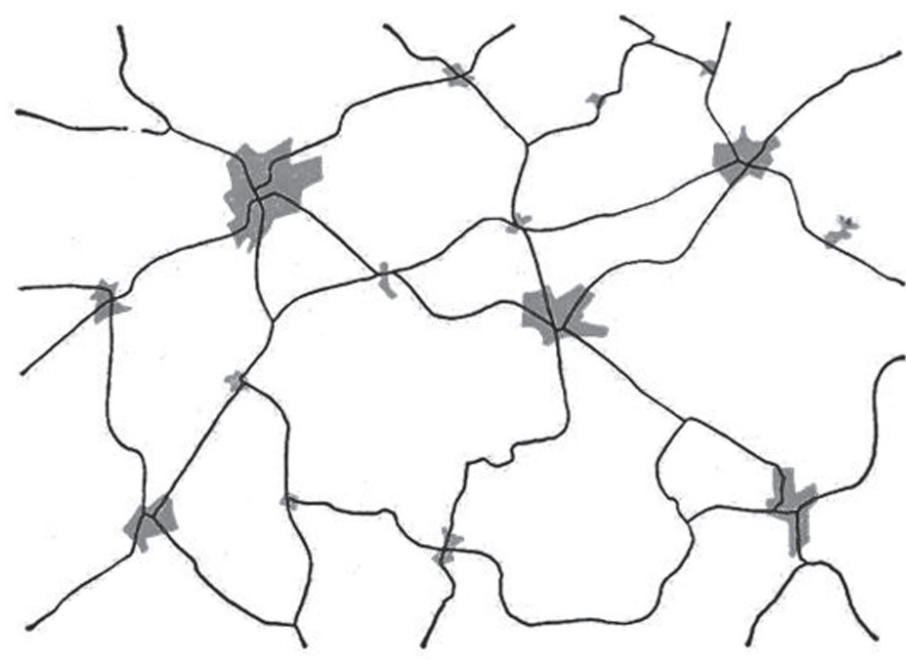

Figura 29: Traffic in Towns: origem do tráfego de passagem nas cidades inglesas Fonte: BUCHANAN, 1963: 34 
Mitchel e Rapkin deveria merecer o mesmo tratamento pelos planejadores urbanos.

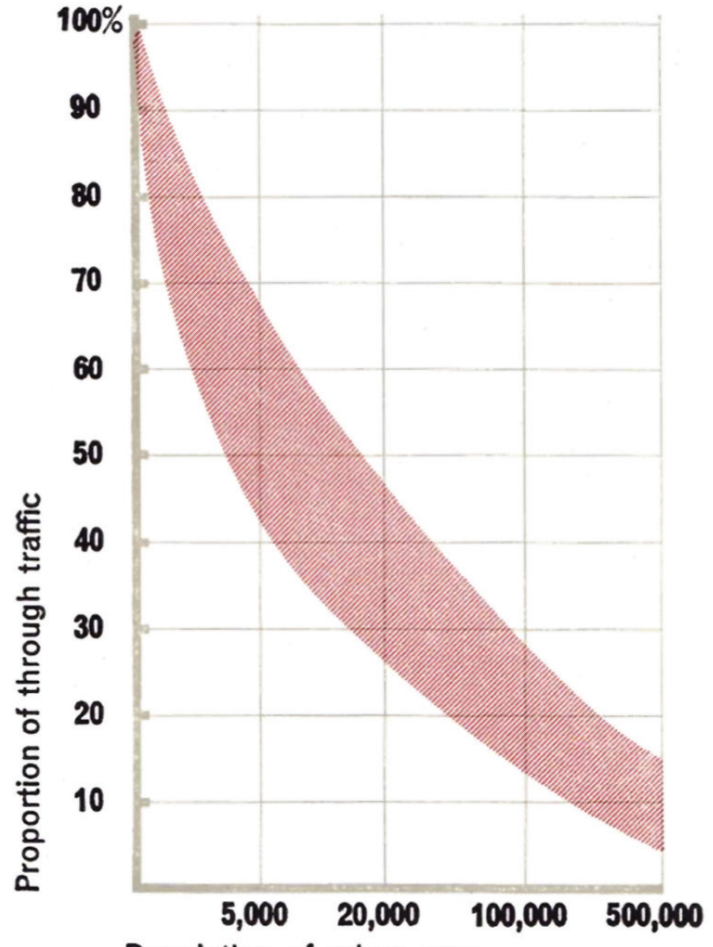

Population of urban area

Gráfico 3: Traffic in Towns: relação entre o

tamanho das cidades e a proporção atribuída ao tráfego de passagem

Fonte: BUCHANAN, 1963: 34
A origem do tráfego de passagem interurbano, segundo o engenheiro-urbanista britânico, podia ser explicada como uma herança do período pré-motorização, quando as cidades eram ligadas pelos seus centros. Essa configuração atendia a jornadas a cavalo que necessitavam de paradas em seus trechos diários. Nas condições de circulação da época, esta configuração vinha prejudicando sobremaneira o desempenho regional dos automóveis.

Neste aspecto, Buchanan faz uma de suas poucas concessões à dimensão regional do tráfego no relatório Traffic in Towns. Para ele, este problema deveria ser cuidadosamente analisado, já que a dinâmica comercial das pequenas cidades neste modelo era profundamente dependente do tráfego de passagem.

O gráfico elaborado para Traffic in Towns buscava demonstrar a participação deste tipo de movimento nas cidades de acordo com seus tamanhos. Buchanan procurava mostrar como as cidades menores, particularmente aquelas com menos de 20 mil habitantes, apresentavam grande participação do tráfego de passagem na composição do volume total em circulação ${ }^{24}$.

Mas por outro lado, sendo as cidades as maiores produtoras de viagens, Buchanan também pretendia mostrar que o "fantasma" era bem menor do que vinha sendo divulgado, pois os volumes de tráfego envolvidos eram de fato muito menores do que se supunha para os assentamentos mais populosos e, portanto, mais sujeitos ao congestionamento. Ficava claro que, para as maiores cidades onde o problema do tráfego de passagem era considerado mais difícil, a sua participação não ultrapassava $20 \%$. No caso de Londres, por exemplo, o valor atribuído à participação destes deslocamentos era inferior a $10 \%$.

24 Este argumento já havia sido utilizado em Mixed Blessing e fora baseado no manual produzido pela H.M.S.O: “Design and Layout of Roads in Built Up Areas", de 1946. 


\section{O debate em torno do modelo radio-concêntrico}

Desde o período inicial de suas formulações sobre a circulação urbana, no final dos anos 1950, em Mixed Blessing, Colin Buchanan se dedicou à discussão sobre o modelo radio concêntrico. Sua intenção era discutir as teorias da época, que segundo ele, tinham duas ênfases: as vias perimetrais (ring roads) e os precincts, ambas focadas no tráfego de passagem.

Para ele, a idéia dos anéis viários concêntricos, uma solução clássica para este problema desde o início do século, e a noção de by pass não eram conceitualmente corretas. Sendo as cidades as maiores produtoras de viagens, a idéia de criar dispositivos para desvio do tráfego não se sustentava, pois os volumes de tráfego envolvidos, como visto anteriormente, eram de fato muito menores do que supunham os defensores deste conceito.

Naquele momento, no final dos anos 1950, o debate tinha endereço certo: Patrick Abercrombie e Alker Tripp, dois dos principais expoentes da discussão sobre circulação urbana na Grã-Bretanha. Tanto as propostas de Tripp ${ }^{25}$, para uma situação ideal de cidade, quanto as de Abercrombie e Forshaw ${ }^{26}$ para Londres possuíam muito em comum nas suas linhas gerais: criavam uma estrutura urbana baseada na lógica de pelo menos um anel perimetral, que determinava locais preservados do tráfego de passagem, os precincts.

Esta forma de organização da circulação e sua associação com os precincts era, naquele momento, uma espécie de lugar comum no planejamento urbano do Reino Unido. Havia naturalmente uma forte ligação destes conceitos com a teoria de Cidade Jardim, de Howard, e seus desdobramentos norte-americanos de Subúrbio Jardim e de Unidade de Vizinhança. Lewis Keeble em seu livro "Principles and Practice of Town and Country Planning” (KEEBLE, 1959), publicado pela primeira vez em 1952, apresenta um diagrama bastante ilustrativo do conceito trabalhado por Tripp, Forshaw e Abercrombie ${ }^{27}$.

25 Town Planning and Road Traffic, de 1938.

26 County of London Plan, de 1943.

27 Nigel Taylor (2008) considera este livro como um verdadeiro manual para sua geração. 


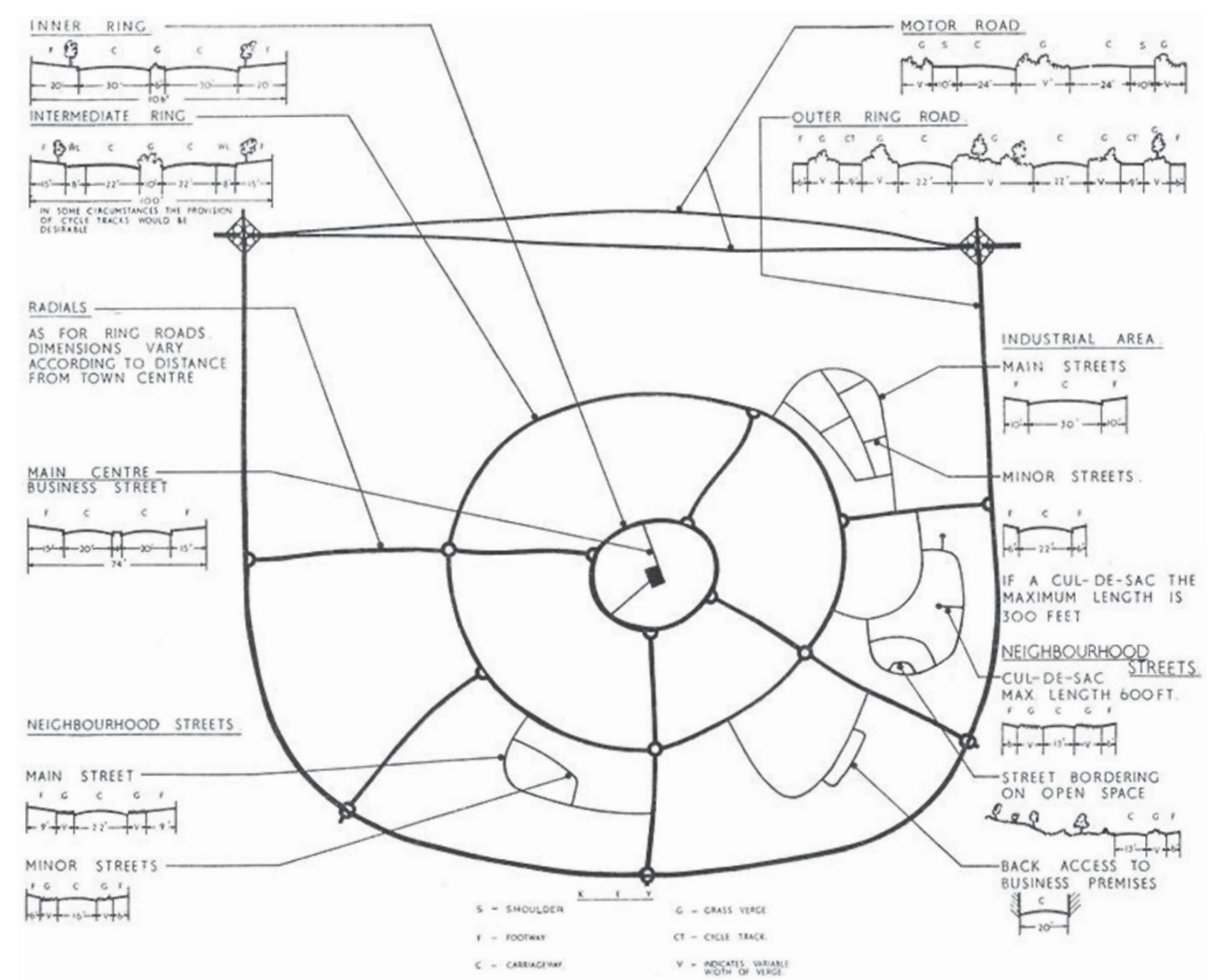

Figura 30: Diagrama de um sistema viário estrutural para uma cidade conceitual Fonte: KEEBLE, 1959: 134

A esta altura o conceito de ring roads já possuía aval governamental. Para Colin Buchanan, os reports "Design and layout of roads in build-up areas" (HSMO, de 1946) e "Redevelopment of Central Areas" (Ministry of Town and Country Planning) afirmavam uma forte indicação de política pública neste sentido (BUCHANAN, 1958). 
Como visto, Alker Tripp baseava sua proposta na importância das áreas preservadas do tráfego de passagem, tendo em vista a incompatibilidade entre pedestres, ciclistas e veículos. E é a partir desta escala, a dos precincts, que ele propunha uma malha de vias organizadas hierarquicamente em arteriais, sub-arteriais e locais (TRIPP, 1950). O esquema

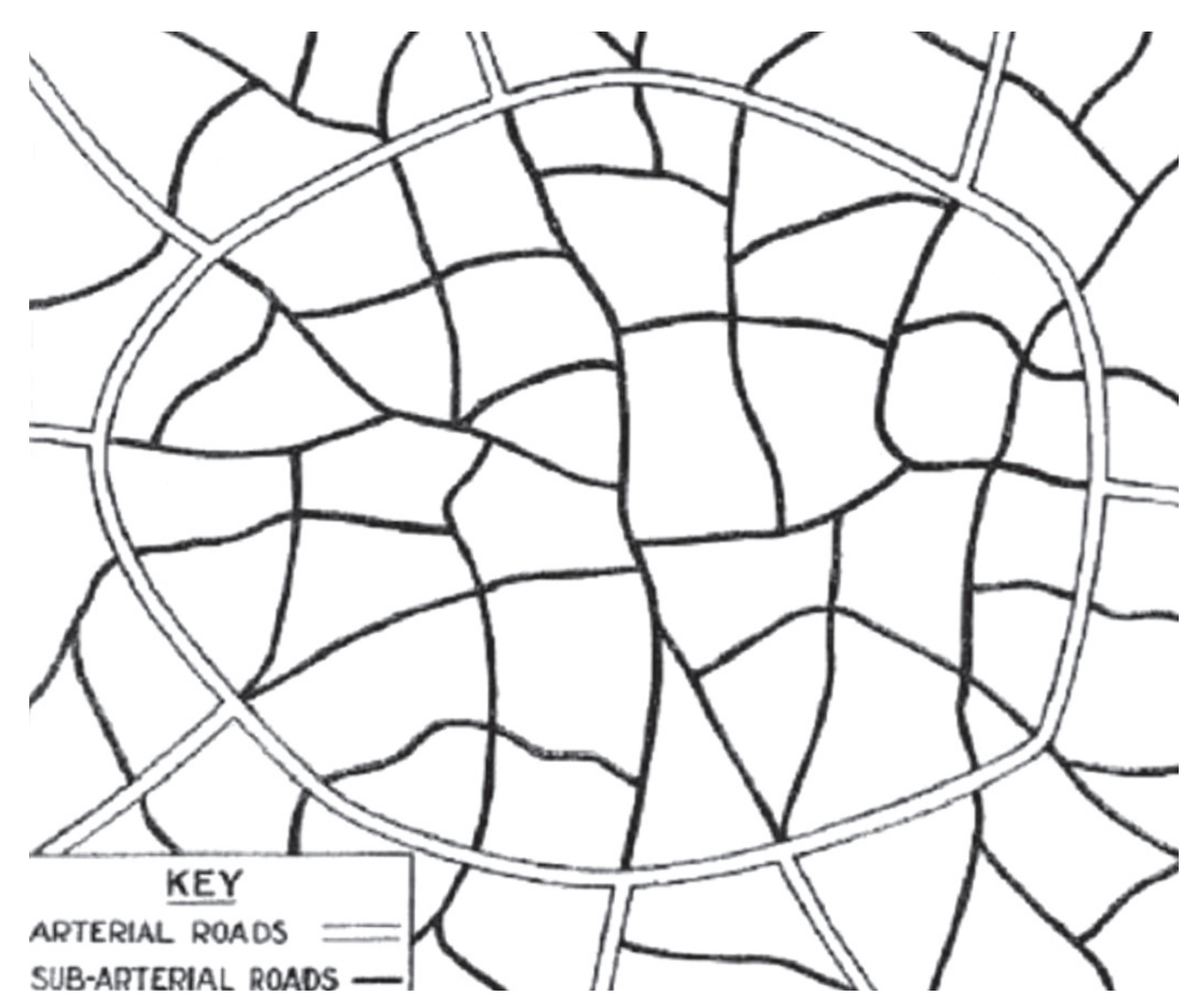

Figura 31: Hierarquia de vias estruturais segundo Alker Tripp Fonte: TRIPP, 1950: 331 
de vias estruturais apresentado por Tripp não deixa dúvidas que seu principal interesse estava ancorado nas áreas livres de tráfego. No diagrama, as vias sub-arteriais não parecem construir nenhum raciocínio mais nítido de organização da circulação do ponto de vista urbano, mas apenas uma mediação entre os dois extremos da escala hierárquica.

Abercrombie e Forshaw, no Plano de Londres de 1943, chegaram praticamente ao mesmo resultado como estrutura urbana; sendo bastante influenciados pelo discurso de Alker Tripp. No entanto, ao contrário de Tripp, a montagem do raciocínio de Abercrombie e Forshaw parece iniciar-se pelo outro extremo da questão: a necessidade de desviar o tráfego de passagem.

Ou seja, o conceito de precincts seria uma decorrência da organização de um sistema viário estrutural. De fato, os autores do Plano para Londres estavam diante de uma situação concreta e a principal preocupação se calcava na escala da cidade como um todo e não exclusivamente nas questões relacionadas à circulação, muito menos na escala local.

A seqüência de objetivos estabelecidos no plano para Londres, no que diz respeito à circulação, não deixa dúvidas a respeito da sequência de raciocínio (FORSHAW; ABERCROMBIE, 1943):

- melhoramento da circulação de veículos

- segregação do tráfego de longa distância do tráfego local

• redução do número de acidentes

- manutenção das comunidades existentes livres do tráfego de passagem ou, onde estas vias já estão presentes, prover rotas alternativas entre as comunidades.

Não por acaso, uma referência da proposta para Londres foi uma Pesquisa de Densidades de Tráfego no sistema viário estrutural realizada pelo Metropolitan Police and the Cenus of Traffic, em 1937. Os resultados eram bastante nítidos: as maiores densidades veiculares 
ocorriam nas proximidades da área central, na área ao norte do Rio Tamisa; com destaque também para o grande volume de tráfego nas interseções centrais, representados pelos círculos em preto.

Diante disso, o esquema viário estrutural proposto foi baseado em um conjunto de três vias perimetrais - as ring roads - e onze vias radiais. A hierarquização das vias pode

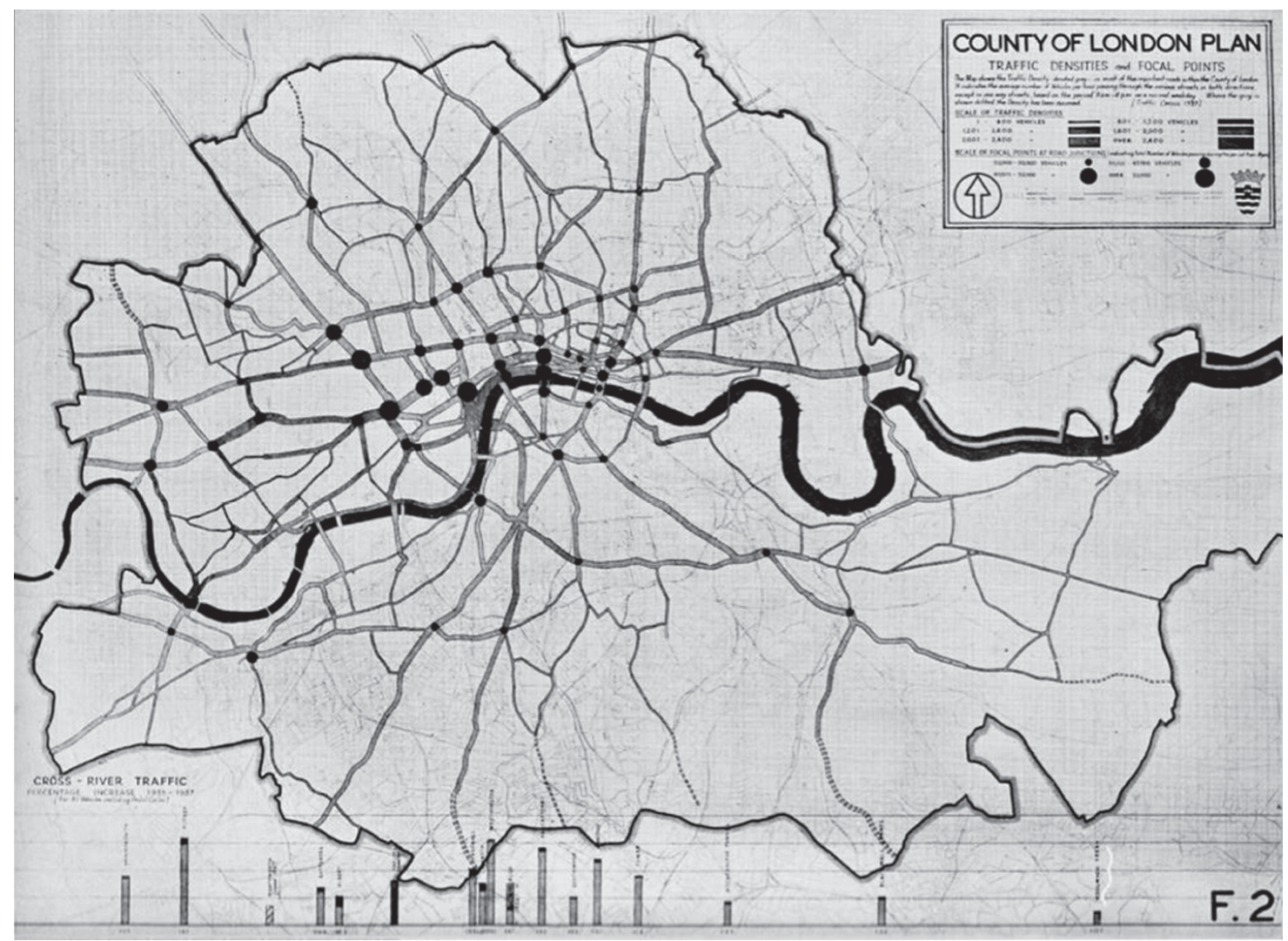

Figura 32: Pesquisa de Densidades de Tráfego no sistema viário estrutural de Londres, dia típico das 8h-20h

Fonte: Metropolitan Police and the Cenus of Traffic, 1937 In: Forshaw; Abercrombie, 1943: Plate XVIII 
ser considerada um desdobramento da proposta de Tripp, subdividindo as vias locais em três subcategorias: major local traffic roads, local roads e park, roads. (ABERCROMBIE; FORSHAW, 1943)

As vias radiais eram, em sua grande maioria, resultado da proposta de ampliação de vias já existentes. Estas vias eram objeto de preocupação, pois agrupavam no mesmo espaço várias demandas, como o tráfego de passagem, manobras de estacionamentos, travessias de pedestres etc. O Plano previa ainda uma série de passagens em desnível como forma de solucionar os problemas das interseções, apontados na pesquisa de 1937.

As vias perimetrais foram as que mereceram mais atenção, sendo divididas em $A, B$ e $C$ Ring Roads. As primeiras seriam as mais próximas do centro de Londres, utilizariam vias já existentes e estariam associadas às estações finais da malha ferroviária. O destaque, neste caso, era a ampliação deste circuito para o sul do Rio Tamisa, prevendo sua transposição em túnel.

O circuito das vias perimetrais do tipo B, situava-se a distâncias entre 1,5 km e 2,7 $\mathrm{km}$ do primeiro anel viário. Sua principal função era servir como by pass em relação ao centro de Londres, a uma distância apropriada e servindo como principal rota para o tráfego de caminhões entre o porto e a área oeste de Londres (FORSHAW; ABERCROMBIE, 1943). Segundo os autores, havia uma vocação desta via para receber grandes edifícios, instituições etc. A este circuito estaria associada uma seqüência de espaços verdes, que, possivelmente, tinha como função isolar a via dos problemas relacionados aos usos lindeiros.

O circuito $\mathrm{C}$ de perimetrais foi o menos aprofundado no Plano, já que dependia da anuência de outros governos locais, assunto que seria tratado só um ano mais tarde, quando Abercrombie desenvolve o Plano para a Grande Londres.

Associado a este modelo de organização viária, Abercrombie desenvolveria a proposta de transferência de um milhão de habitantes da Grande Londres para as cidades novas 


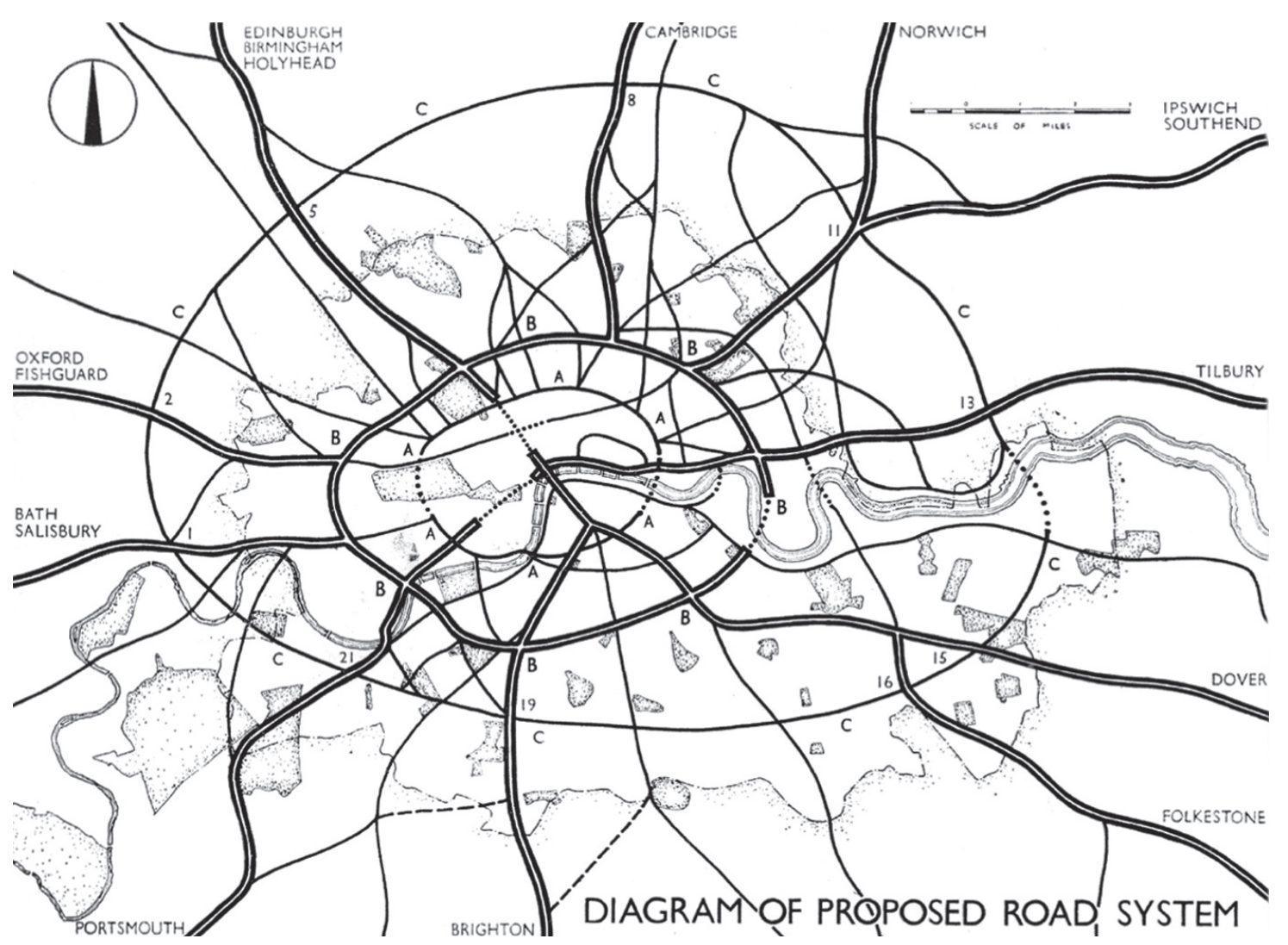

Figura 33: Diagrama do sistema viário estrutural proposto por P. Abercrombie e J. Forshaw para o Plano de Londres em 1943

Fonte: FORSHAW; ABERCROMBIE, 1943: 120

(Great London Plan, de 1944). De fato, o problema para Abercrombie era o de "congestão da cidade" ${ }^{28}$.

28 Patrick Abercombrie em seu Greater London Plan de 1944 previa a transferência de 400 mil habitantes já existentes e outros 600 mil que viriam a morar na capital, o que totalizaria um milhão de habitantes. O excedente populacional de 400 mil habitantes seria distribuido por oito cidades novas de 50 mil habitantes no entorno de Londres (entre 35 e $60 \mathrm{~km}$ ). O outro excedente, de 600 mil habitantes, seria alocado em cidades existentes localizadas entre 50 e $80 \mathrm{~km}$, a partir de Londres, abrigando 60 mil pessoas cada uma. Propunha ainda a configuração de um cinturão verde de aproximadamente oito quilômetros de largura, situado ao redor de Londres, com o objetivo de bloquear a expansão horizontal da cidade. 


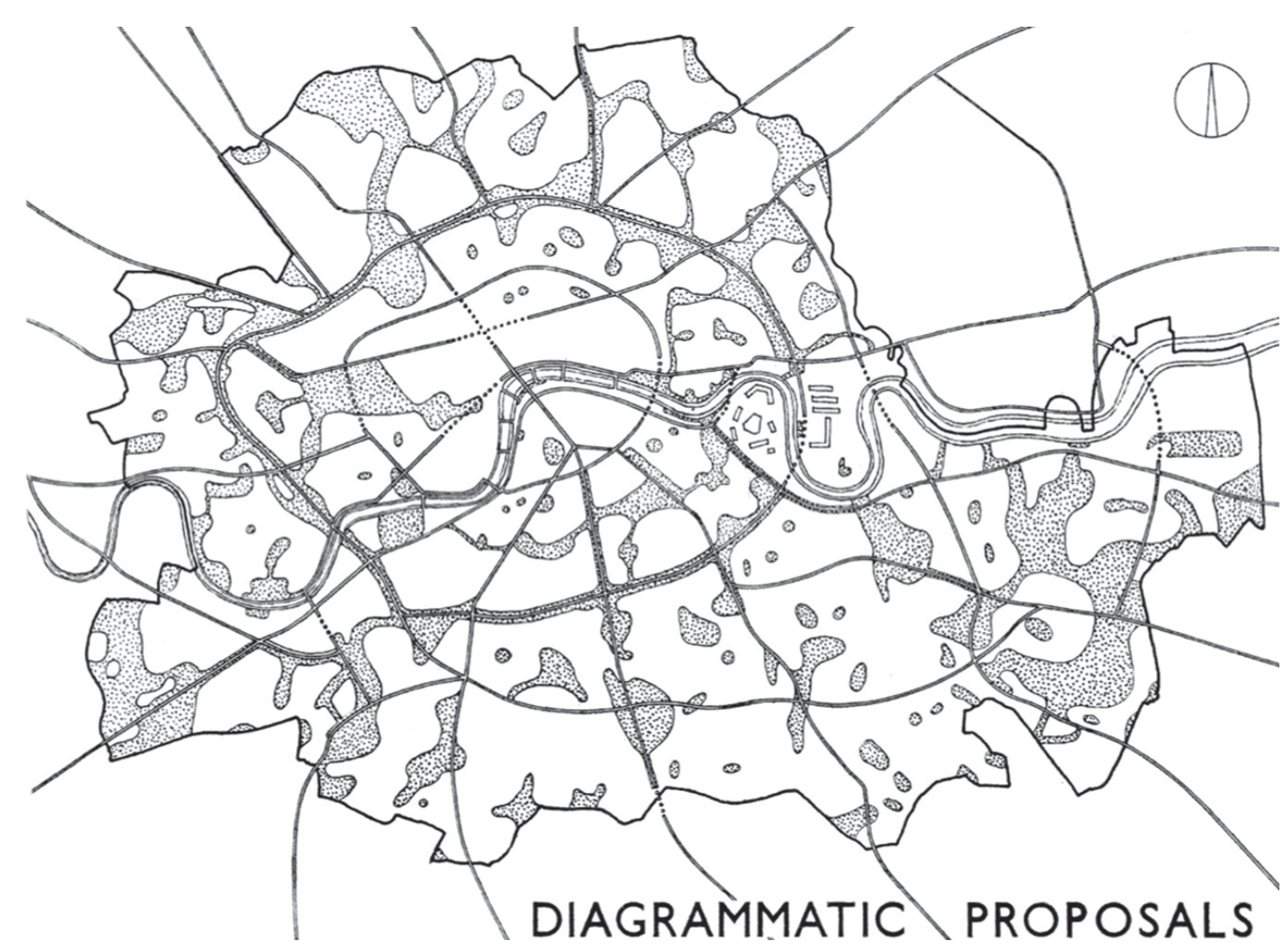

Figura 34: Diagrama do sistema de espaços verdes proposto por P. Abercrombie e J. Forshaw para o Plano de Londres em 1943

Fonte: FORSHAW; ABERCROMBIE, 1943: 46

Colin Buchanan destacou esta constatação, e não as propostas para o sistema viário, como a maior contribuição dos Planos de 1943 e 1944: chamar atenção para o congestionamento como resultado do excessivo crescimento de Londres, não somente na periferia, mas sobretudo no centro. Ou seja, a solução que Abercrombie propunha era assentada na redução da densidade de uso e não somente pelo viés do provimento de infra-estrutura para circulação, numa clara associação entre uso do solo e viagens. 
“(...) This idea of tackling the problem from the other end, as it were, by reducing the traffic-potential of the centre was entirely novel and was an imaginative step forward". (BUCHANAN, 1958: 154)

Entretanto, embora tenha reconhecido esta qualidade do Plano para Londres, suas divergências se manteriam em relação às questões de circulação. Colin Buchanan havia trabalhado por um curto período de tempo no London Division Section e acompanhou os problemas relacionados à implantação do Plano para Londres. Segundo ele,

“'The ' $A$ ' ring as a proposal survived in various forms for some years, but was finally rejected for a variety of reasons, amongst which may be noted the significant problem of staging. The construction of the complete road as a single project within a defined period evidently could not be visualized at all in view of the enormous cost and great interference with property: and the wisdom of building short lengths of doubtful utility here and there, which might take half a century to link up into a complete road, was questioned". (BUCHANAN, 1958: 157)

Embora evidentemente estas fossem boas razões para o questionamento da proposta, Buchanan parecia divergir mais pelo caminho da compreensão da natureza do tráfego urbano. Novamente, a questão seria a ênfase no tráfego de passagem. Segundo ele, este conceito estaria baseado em um pressuposto meramente intuitivo, sem respaldo científico.

Apenas dois anos depois da publicação de Mixed Blessing o engenheiro urbanista teve uma oportunidade de testar seus conceitos a partir de quatro estudos de caso, por ocasião de Traffic in Towns: para Newburry, Leeds, Norwich e Londres, respectivamente consideradas como cidades pequena, grande, histórica e metrópole. Curiosamente, os argumentos contra o modelo radio-concêntrico não se sustentaram plenamente, como seria de esperar.

Este fato se torna ainda mais instigante. Naquele momento os estudos empreendidos

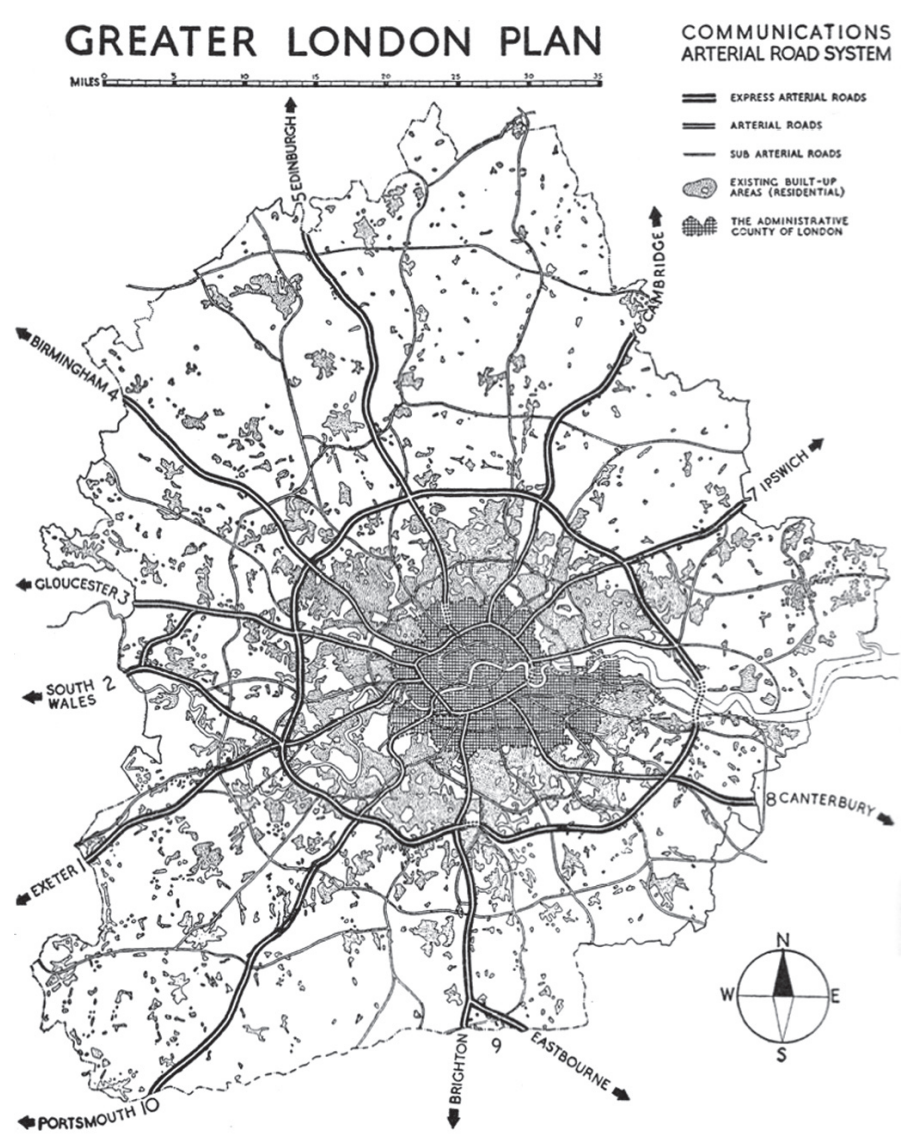

Figura 35: Diagrama do sistema viário estrutural proposto por P. Abercrombie para o Plano da Grande Londres em 1944 ( Fonte: BUCHANAN, 1958: 156 
em Traffic in Towns já dispunham de modelos para simulação de tráfego, ao contrário do que ocorrera com Abercrombie. Por meio deles era possível dispor de uma ferramenta extremamente útil: os diagramas de desejos de viagens. No caso mais sintomático, o ensaio para Leeds, esta ferramenta não deixava dúvidas sobre a natureza da maioria dos desejos de deslocamento: eram radiais. Ao que parece, a intuição de seus colegas urbanistas tinha algum fundamento.

Em conseqüência, o sistema viário estrutural indicado acompanhou os resultados dos diagramas, configurando-se radio-concentricamente. A alternativa de máxima motorização e pleno investimento previa treze vias radiais com status de motorways, isto é, completamente segregadas do tráfego local. Buchanan acabou por considerar esta configuração inviável e admitiu que haveria necessidade de controle dos deslocamentos por automóveis. Optou então por uma alternativa mais modesta deste ponto de vista, com investimentos de nível intermediário.

A conformação radial dos deslocamentos se repete no estudo de Norwich, o exemplo de uma cidade "histórica" em Traffic in Towns. No entanto, uma melhor visualização desta relação entre o sistema radio-concêntrico e cidades com vigoroso patrimônio histórico pode ser encontrada no estudo de tráfego para Canterbury, de 1970. Neste caso, Buchanan e sua equipe consideraram quatro alternativas para estruturação do sistema viário. Em todas elas o centro é considerado como uma área de preservação do tráfego de passagem e sua delimitação é realizada por avenidas perimetrais, criando assim uma "área motorizada", fora da área histórica, e uma "área prioritariamente não motorizada", interna à muralha.

Já no estudo de caso para Londres, em Traffic in Towns a dimensão da circulação na cidade como um todo não foi considerada como objeto de trabalho. O relatório também não apresentou qualquer explicação para essa curiosa ausência. Ao omitir uma avaliação mais cuidadosa sobre a circulação para toda a área de Londres, Colin Buchanan parecia esquivar-se do debate com Abercrombie e seus dois planos, considerando apenas o que lhe era conveniente naquele momento. De fato, Buchanan, em 1963, não apresentava 


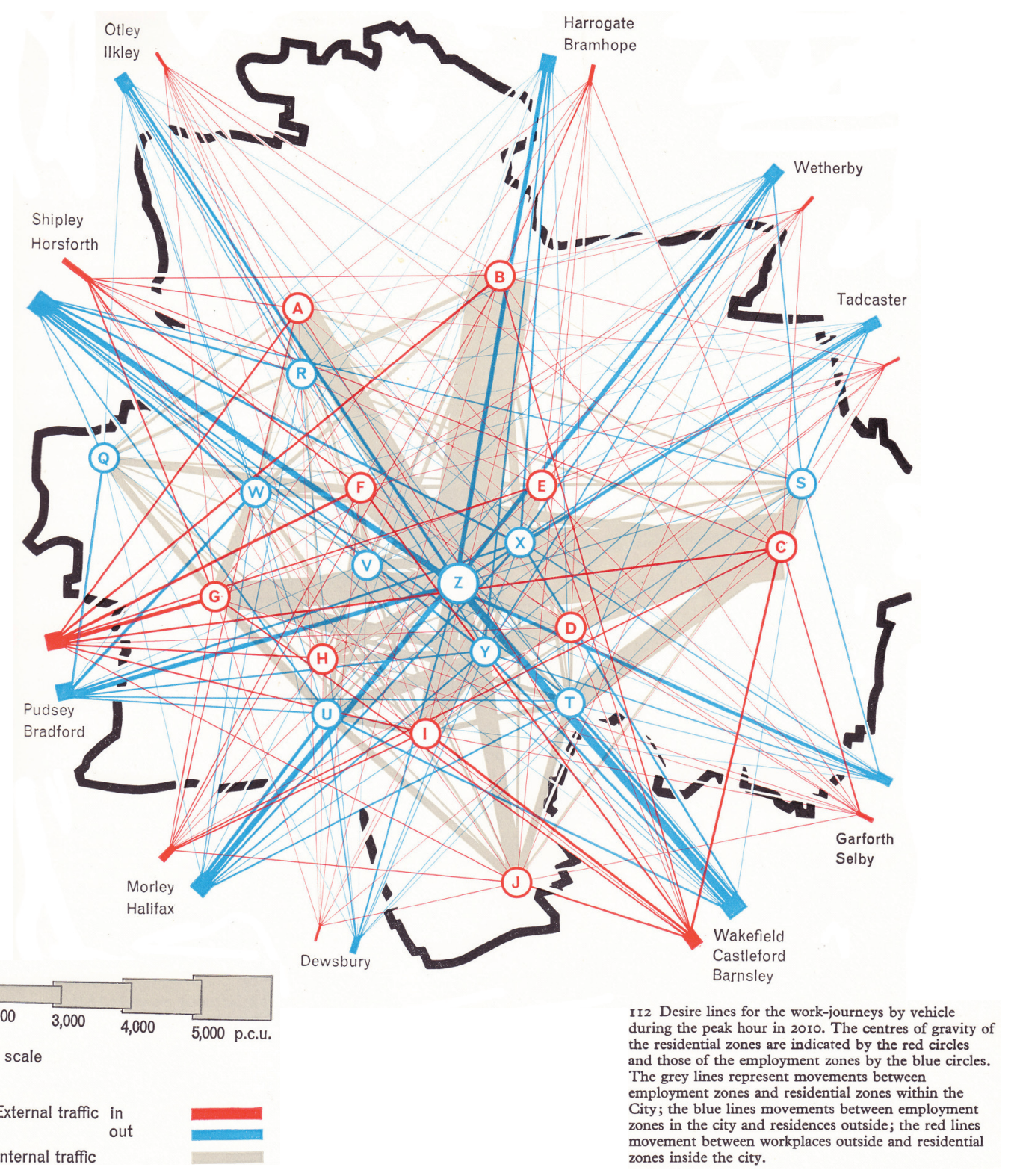

Figura 36: Traffic in Towns: Diagrama de desejos de viagens por motivo de trabalho para a cidade de Leeds Fonte: BUCHANAN, 1963: 87
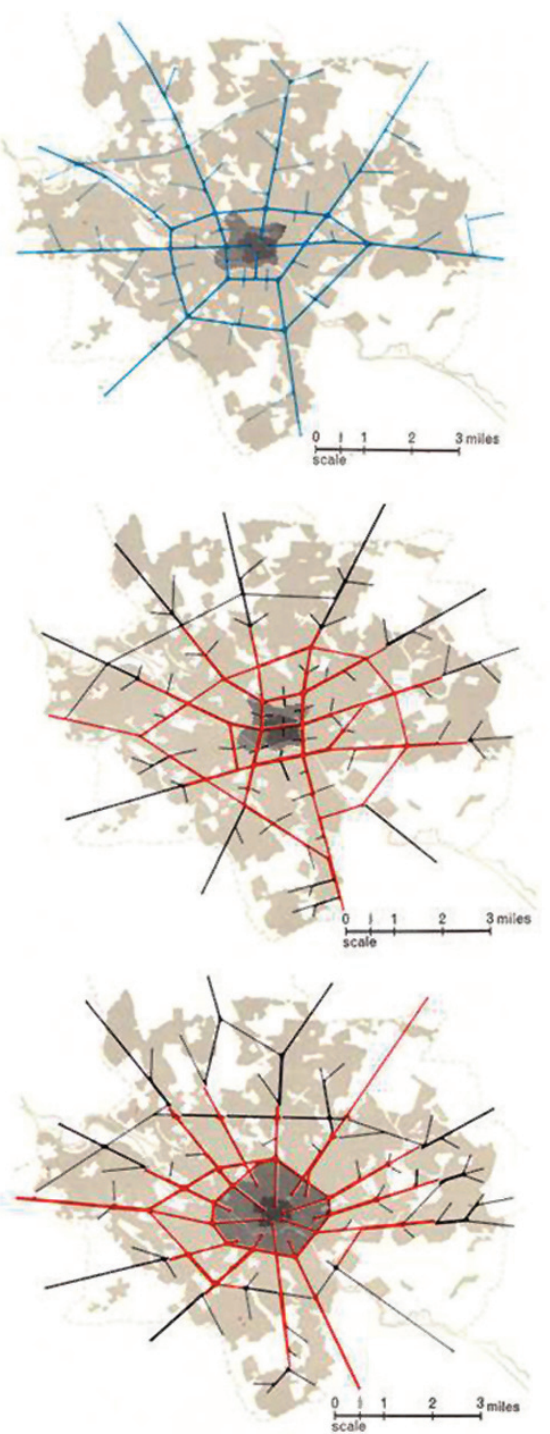

Figura 37: Traffic in Towns:

Alternativas para sistema viário

estrutural de Leeds, para os

cenários de intervenções mínima,

intermediária e plena

Fonte: BUCHANAN, 1963: 93-96 


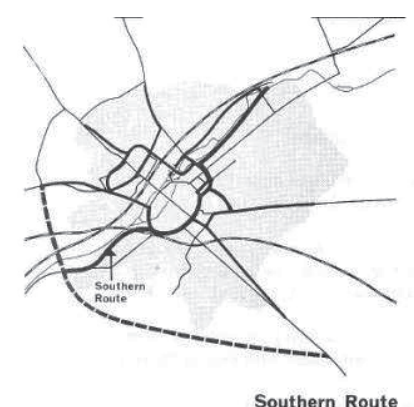

Southern Route
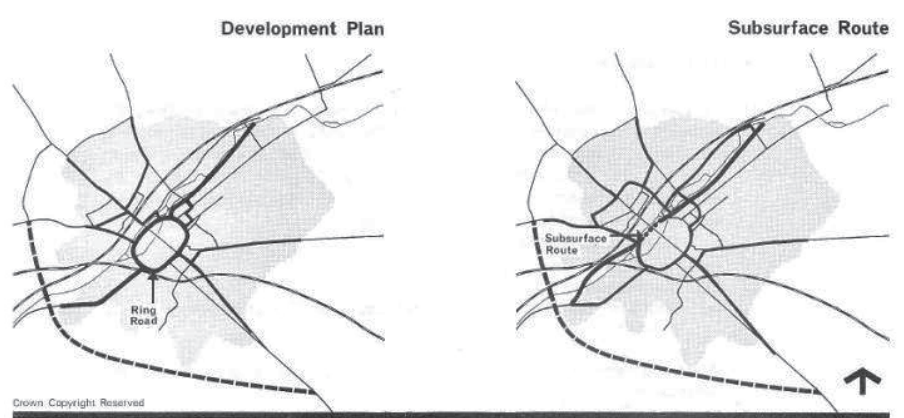

Built we areat

Existing roads

Proposed dual carriagewas

Figura 38: Canterbury Traffic Study, Colin Buchanan\&Partners, 1970 - alternativas para sistema viário estrutural Fonte: COLIN BUCHANAN\&PARTNERS, 1970a: fig 5 mais a mesma avaliação resoluta sobre o modelo radio-concêntrico, como fizera em 1958. Os estudos de caso, embasados nas modernas ferramentas de modelagem, mostraram que a questão deste modelo nas cidades existentes era bem mais complexa do que poderia parecer inicialmente.

A questão da contraposição com os planos de Abercrombie, no entanto, apresentava outra face. Não se trata meramente de uma discussão sobre projeto viário ou de alternativas para vias de circulação, mas sim de uma abordagem sobre a relação entre tráfego e cidade. Não é por acaso que a investida se dá prioritariamente contra um urbanista (Abercrombie) e não contra um especialista em tráfego (Tripp).

Embora Traffic in Towns tivesse demonstrado fragilidade em alguns de seus argumentos, a questão radio-concêntrica permaneceria subjacente nas suas atividades como consultor. Pouco tempo mais tarde, entre 1964 e 1966, o Estudo para South Hampshire retomaria a discussão sobre este modelo e voltaria a se contrapor não mais a Abercrombie somente, mas à principal corrente do planejamento urbano britânico.

\section{A questão das áreas centrais}

Colin Buchanan tratou, quase sempre, muito rapidamente das áreas exclusivamente habitacionais. Em Traffic in Towns este assunto não ocupou mais de uma página (BUCHANAN, 1963). Sua atitude a este respeito pode ser admitida como imprecisa e de menor atenção.

Para ele estas áreas teriam algumas necessidades especiais, como a preferência de acesso direto até a porta das residências, a necessidade de espaço disponível para estacionamentos, a legibilidade urbana de sua organização e, finalmente, as questões ligadas às condicionantes ambientais, como segurança para os pedestres e patamares aceitáveis de ruído.

Estes princípios estariam todos contemplados pelo chamado Radburn Layout, que se 
definiria por dois princípios básicos: a criação de uma "superquadra" livre de tráfego e criação de um sistema de circulação exclusivo para pedestres. Embora não apostasse plenamente na viabilidade deste princípio, sobretudo do ponto de vista da viabilidade comercial, admitia que este arranjo resolvia as demandas identificadas. Ou seja, não havia propriamente um grande desafio colocado neste âmbito.

Além disso, Buchanan, ao que parece, pretendia esquivar-se da discussão envolvendo as primeiras New Towns e suas aplicações dos princípios de Radburn que ocorreram no meio urbanístico dos anos 1950 no Reino Unido. Ele próprio chegou a afirmar que tal conceito só seria viável nas condições de novos assentamentos, afastando definitivamente a possibilidade de considerações destes aspectos para cidades existentes.

Ficava bastante claro no discurso de Buchanan que a principal questão não se encontrava nas áreas exclusivamente habitacionais, ainda que por vezes manifestasse certo desconforto com uma possível expansão indiscriminada destes assentamentos, tal como na experiência norte-americana: "all the American experience of sprawl suggests that in our small country we would do well to have no more of it" (BUCHANAN, 1963: 183).

Eram, ao contrário, as áreas centrais o principal objeto das preocupações do engenheiro-urbanista. O conhecimento da experiência das cidades norte-americanas contribuiu bastante para a construção desta ênfase. Nos seus trabalhos teóricos, Buchanan não deixa passar ao largo o processo de esvaziamento dos centros urbanos que aquele país vinha observando.

Nada mais natural para uma situação em que todas as demandas urbanas, sejam elas de circulação ou estacionamento, estão concentradas. Particularmente, no caso das cidades inglesas este problema se agravava: um tecido urbano antigo e não talhado para a circulação dos automóveis. Admitindo que o automóvel era um modo de transporte que não teria obstáculos para seu crescimento, era preciso a todo custo viabilizar sua convivência com as áreas centrais e seu equilíbrio frágil já ameaçado pela circulação motorizada.
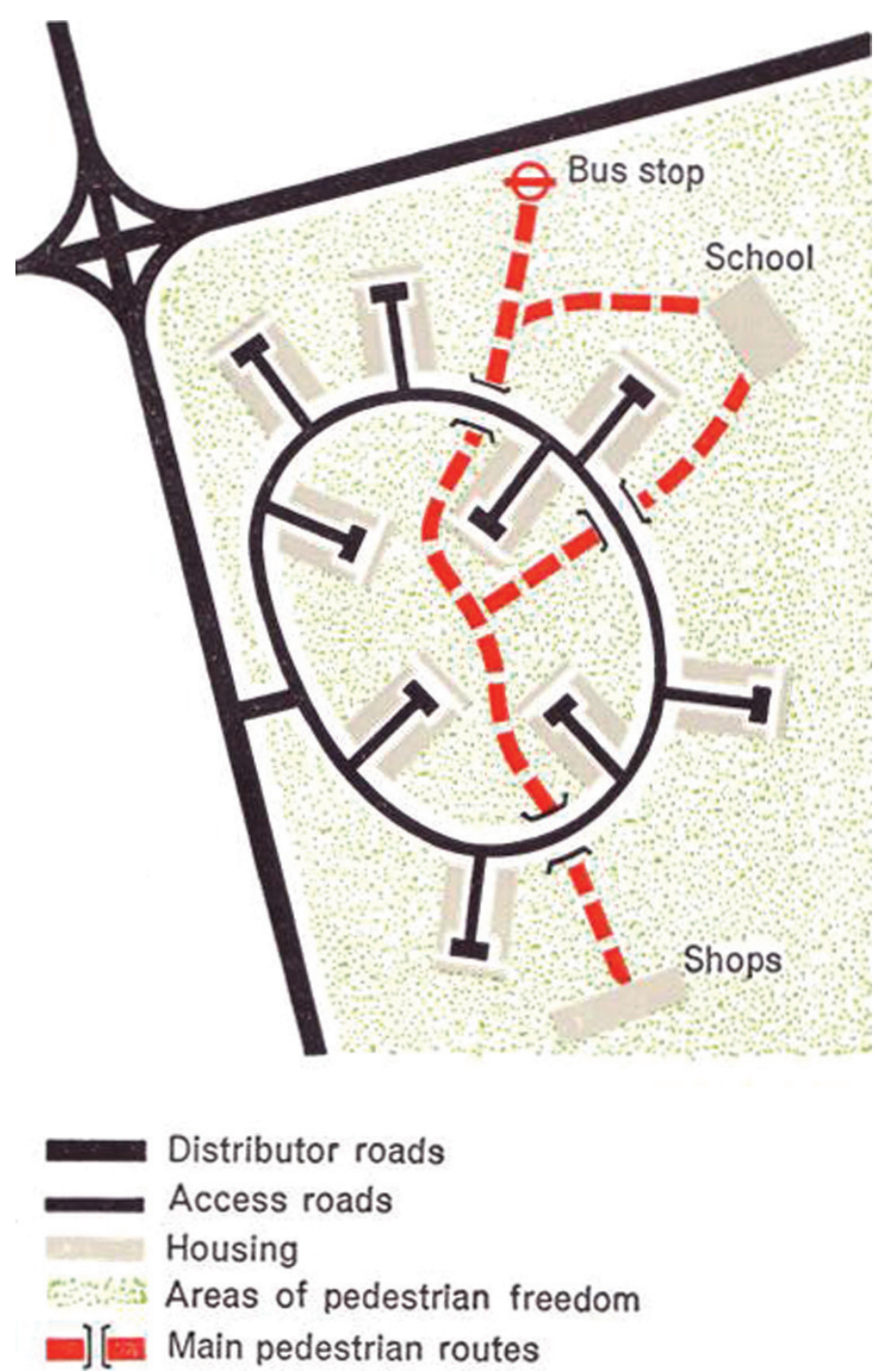

Figura 39: Radburn Layout, conforme Traffic in Towns Fonte: BUCHANAN, 1963: 47 
Assim, viabilizar a presença do automóvel no centro era, para Buchanan, uma questão estratégica. Em todos os seus estudos e planos analisados há sempre uma atenção especial às áreas centrais; sendo que, para elas, foram elaborados levantamentos específicos e estudos particulares. Em Traffic in Towns, o estudo de caso de Londres não se debruça sobre toda a Grande Londres, nem mesmo sobre toda a cidade, mas somente a um quadrilátero situado em uma área de grande movimento, próxima à Tottenham Court Road e à Euston Road. Em outras palavras, viabilizar a presença do automóvel no centro era viabilizar sua presença nas cidades britânicas.

Colin Buchanan, baseado na experiência norte-americana, alertava que o crescimento das taxas de motorização poderiam conduzir a uma menor atividade das áreas centrais. Isto porque o automóvel tinha condições de atingir maiores distâncias e a vinculação das atividades comerciais a um único núcleo de maior acessibilidade estaria seriamente comprometida pela versatilidade deste modo. (COLIN BUCHANAN\&PARTNERS, 1966)

A preocupação com o delicado equilíbrio das áreas centrais não era exclusividade de Buchanan. Gibberd, por exemplo, comenta:

"The chief problem with most town centres is that of overcrowding: too much building and tôo much traffic on too small an area of land; not over the complete area, but over those parts which have become important foci - an intersection of traffic roads, a bus station, a group of multiple stores". (GIBBERD, 1962: 56)

Particularmente, o exemplo de Los Angeles parecia ser um grande motivo de preocupação. Doxiadis, anos mais tarde, em 1968, traduz em termos quantitativos o significado dos resultados da experiência da cidade norte-americana:

"An example of this gradual elimination of the centre can be found in Los Angeles, where two thirds of the downtown area is devoted to traffic, freeways, streets and parking."

(DOXIADIS, 1968: 271). 


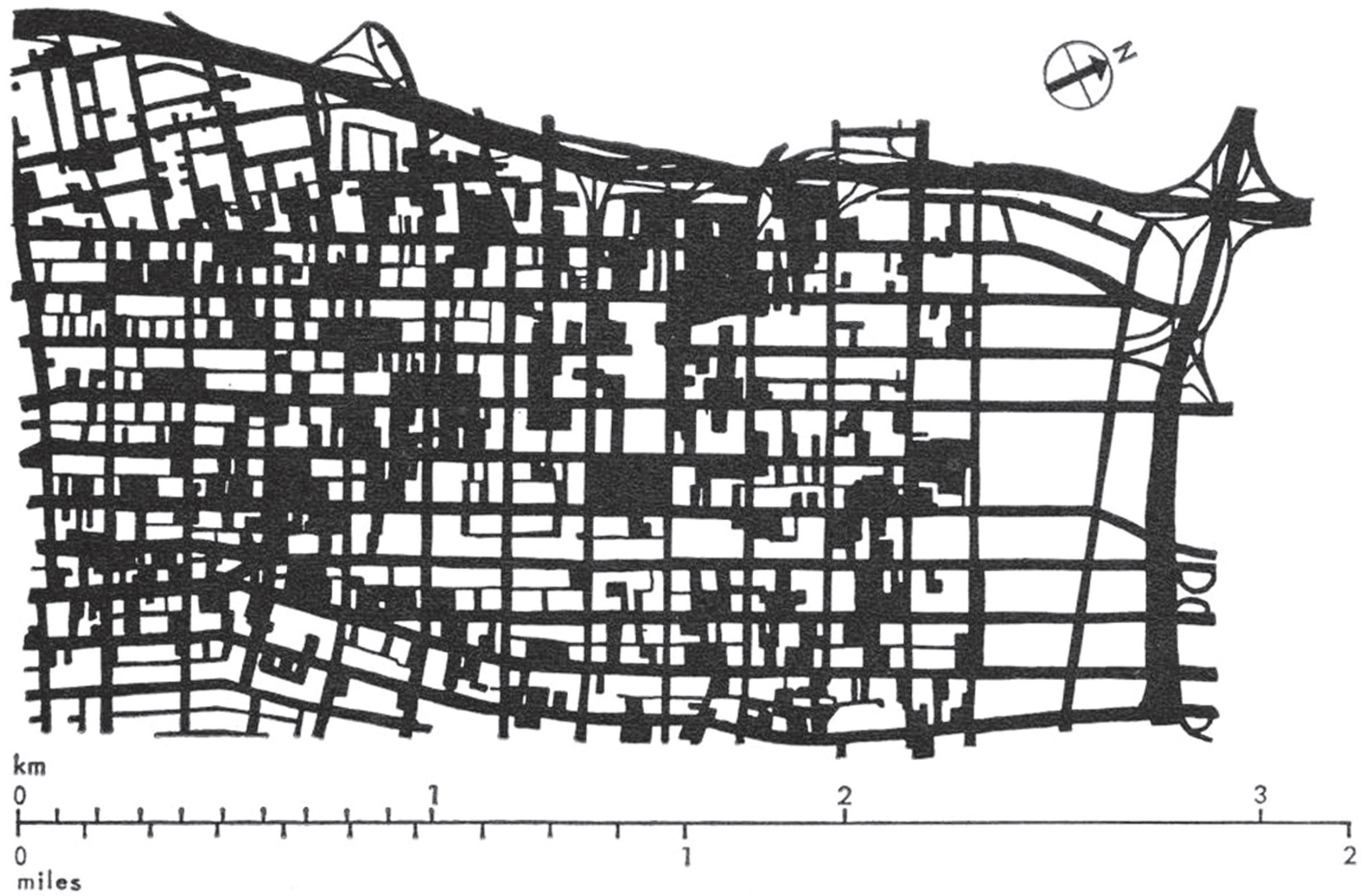

Figura 40: Área ocupada pelo sistema viário e suas atividades atreladas em Los Angeles, EUA Fonte: DOXIADIS, 1968: 273 


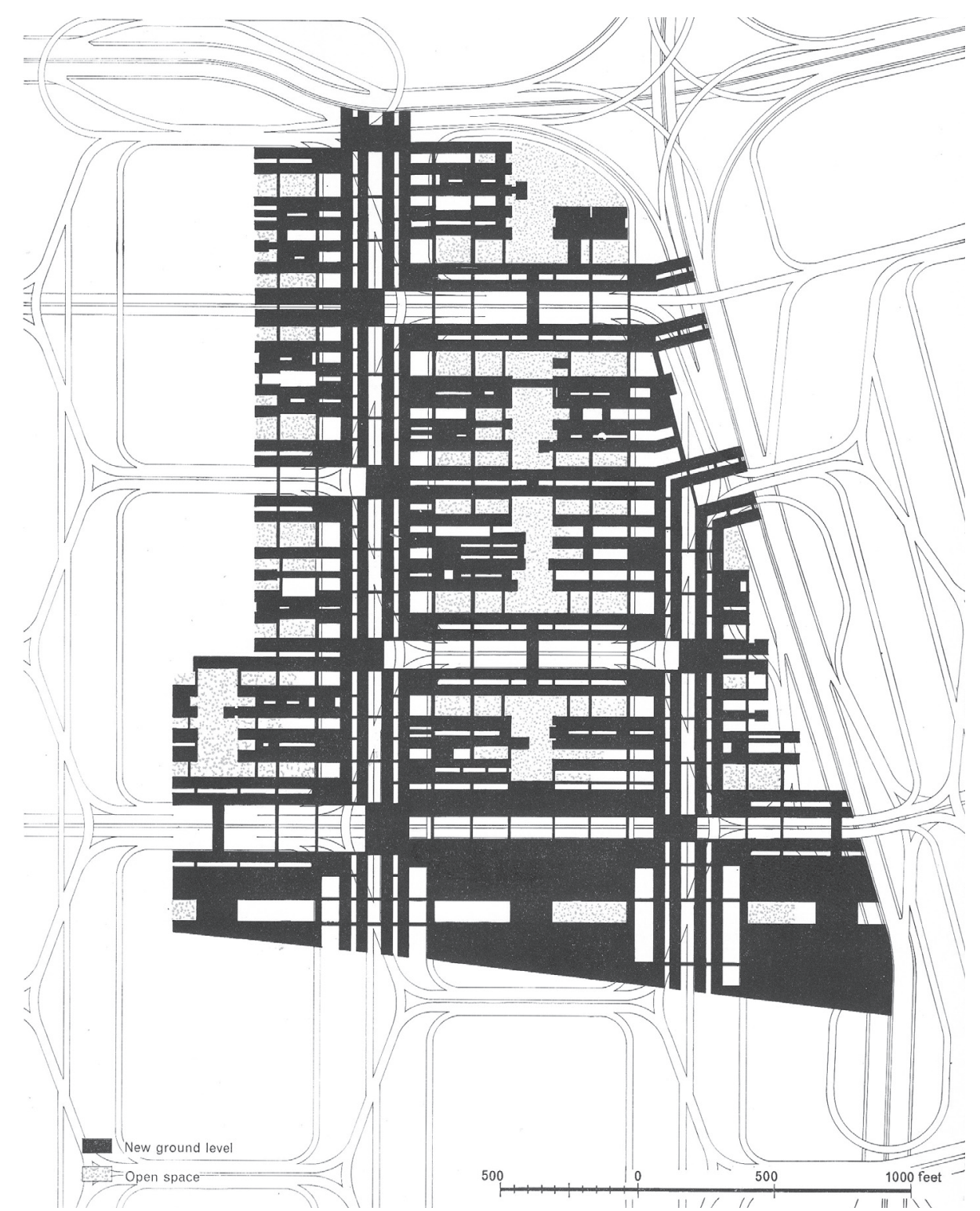

Figura 41: Traffic in Towns: área destinada aos pedestres prevista no estudo para a completa transformação de uma área central de Londres Fonte: BUCHANAN, 1963: 138 
A menção à proporção das áreas destinadas ao tráfego em Los Angeles não é mais contundente que a imagem apresentada também por Constantino Doxiadis. A contraposição desta imagem com a sugestão para a completa reorganização de uma área central de Londres, elaborada por Colin Buchanan e sua equipe em Traffic in Towns, não deixa dúvidas sobre as intenções do engenheiro-urbanista inglês em relação às áreas centrais. Ao contrário da cidade norte-americana, para Londres foi pensado um sistema elevado de vias para pedestres que ocuparia grande parte da área de estudo.

O generoso espaço dedicado aos pedestres no estudo para uma área central de Londres em Traffic in Towns reconhecia a intensificação dos conflitos entre accessibility e environment. Aqui, ao contrário das periferias, as possibilidades de gerenciamento deste conflito não se viabilizariam pela alocação de espaços horizontais diferentes: um para as vias estruturais e outro para o ambiente urbano. O chamado Radburn Layout não teria condições de implantação nestas circunstâncias. A solução então se daria não mais pela reorganização da circulação ou do planejamento, mas na escala do projeto urbano. Os diferentes modos de transporte seriam situados em planos distintos, associados às suas atividades correlatas, conforme se comentará no capítulo seguinte.

Se o conflito entre veículos e pedestres era um pólo da questão das áreas centrais, a disputa de espaço se dava também internamente ao modo automóvel, relacionado às necessidades de estacionamento, constituindo-se outro ponto estratégico desta mesma questão. Já desde Mixed Blessing, em 1958, Buchanan denunciava esta outra face do uso dos carros na cidade. Não se tratava somente do aumento dos veículos em circulação e suas conseqüências indesejáveis, mas igualmente importante, da crescente invasão do espaço urbano por automóveis estacionados.

A associação de espaços de circulação e estacionamentos dentro do mesmo raciocínio analítico apresentava clara referência ao exemplo de Louis Kahn e seu plano para a área central de Filadélfia, conforme visto no capítulo 2. A referência a Kahn seria amplamente empregada em seus estudos e planos como consultor. 
Este problema tinha uma dimensão maior no caso das cidades britânicas mais antigas, onde havia sítios históricos extensos, muitas vezes ocupando toda a área central. No caso de "Bath: a planning and transport study", elaborado em 1965, Buchanan denunciou com ênfase a ocupação de espaços urbanos importantes pelo estacionamento de veículos.

São estas razões que explicam a indissociabilidade entre o plano viário e a localização de estacionamentos no próprio estudo para a cidade de Bath. Neste caso, toda a área central da cidade é margeada por um sistema viário de distribuição, associado finalmente a uma

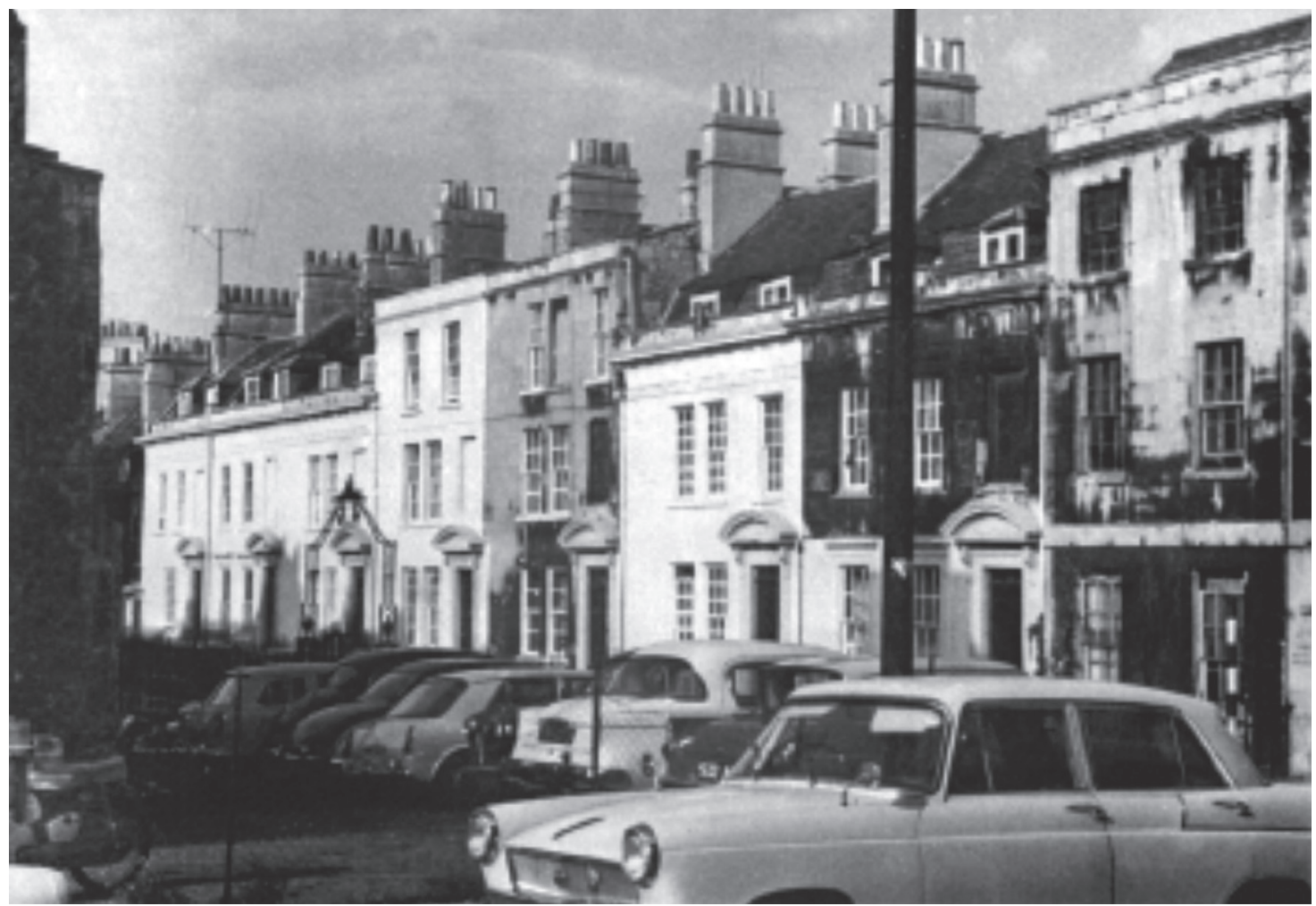

Figura 42: Estacionamento de veículos na área central de Bath. Fonte: COLIN BUCHANAN\&PARTNERS, 1965: fig 10 
rede de estacionamentos. A isto ainda, integra-se uma trama de vias pedestrianizadas, que conduzem os habitantes da cidade aos seus locais de destino no centro da cidade.

Em outro plano, o estudo para a cidade de Cardiff, no ano seguinte, o sistema de estacionamentos ganha mais complexidade. Neste caso, os estacionamentos seriam divididos em longa e curta permanência e seriam determinados pela quantidade de empregos previstos para a área central expandida, segundo o horizonte do plano. Os de longa permanência se implantariam no sistema viário periférico ao centro, enquanto os outros estariam situados dentro da área central.

Anos mais tarde, no plano para Edinburg (1972), o critério de localização dos estacionamentos ganharia ainda mais sofisticação. Neste caso, uma pesquisa elaborada pela equipe de Buchanan mostra a distância de caminhada em dos estacionamentos aos locais de destino e destes até os estacionamentos, dentro das subáreas demarcadas.

O problema dos estacionamentos, na forma pela qual foi tratado por Colin Buchanan, apresentava também outra vantagem, segundo sua linha de raciocínio. Se por um lado atendia uma demanda de ponta das viagens por automóveis, por outro liberava maior espaço viário para circulação. E isto ocorreria justamente nas áreas centrais, as mais carentes de espaço viário.

Este raciocínio distinguia claramente os espaços de circulação e estacionamento e fazia das ruas, ou pelo menos de uma parcela delas, um local cada vez mais voltado para os automóveis em movimento. Nesta situação em que as vias eram concebidas cada vez mais como canais de circulação, a presença dos pedestres se tornava perigosa e, portanto, indesejada. Neste sentido, a verticalização dos conflitos pedestres e automóveis seria uma conseqüência inevitável. É por isso que a dimensão do projeto urbano, como veremos adiante, adquiriu bastante força na construção do discurso de Buchanan.

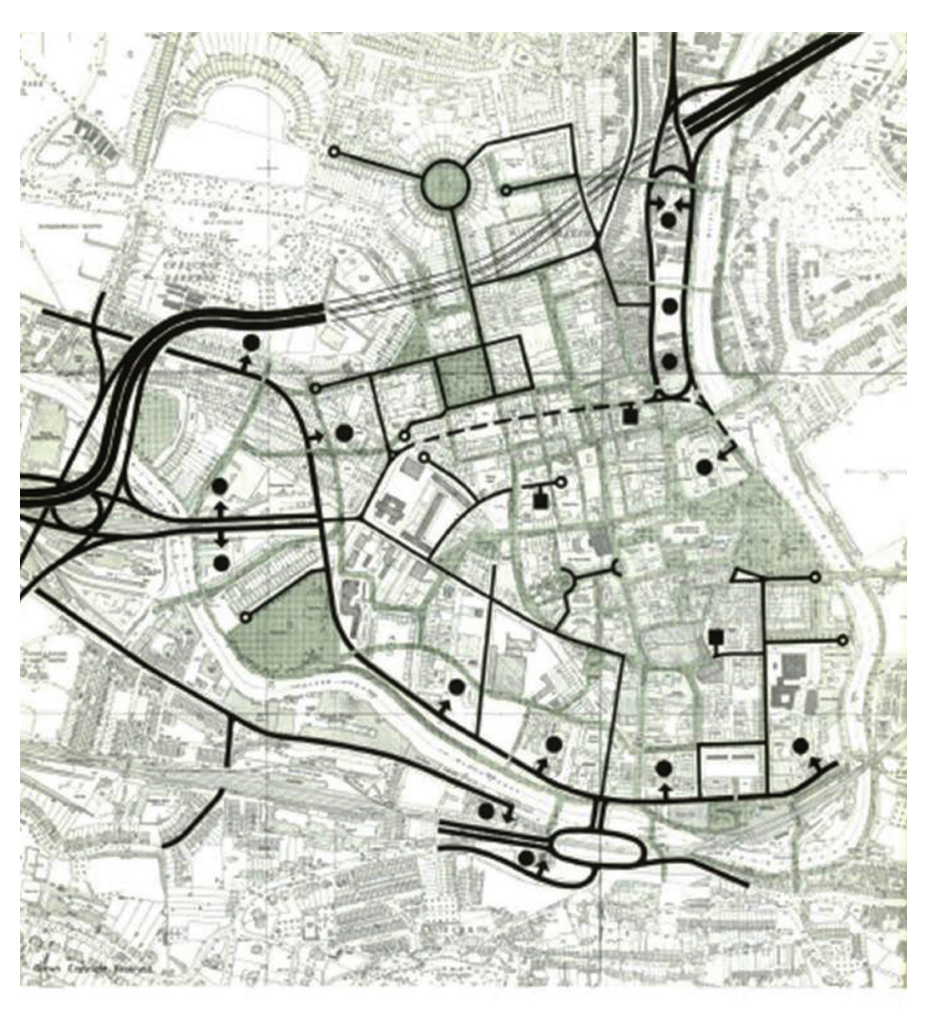

500

1000 yards

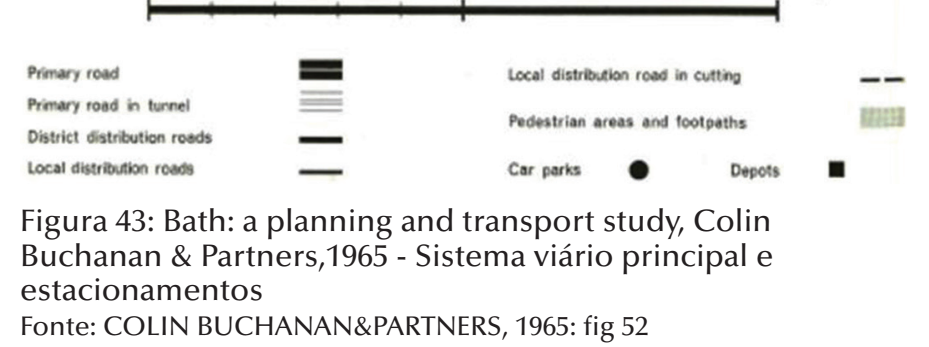




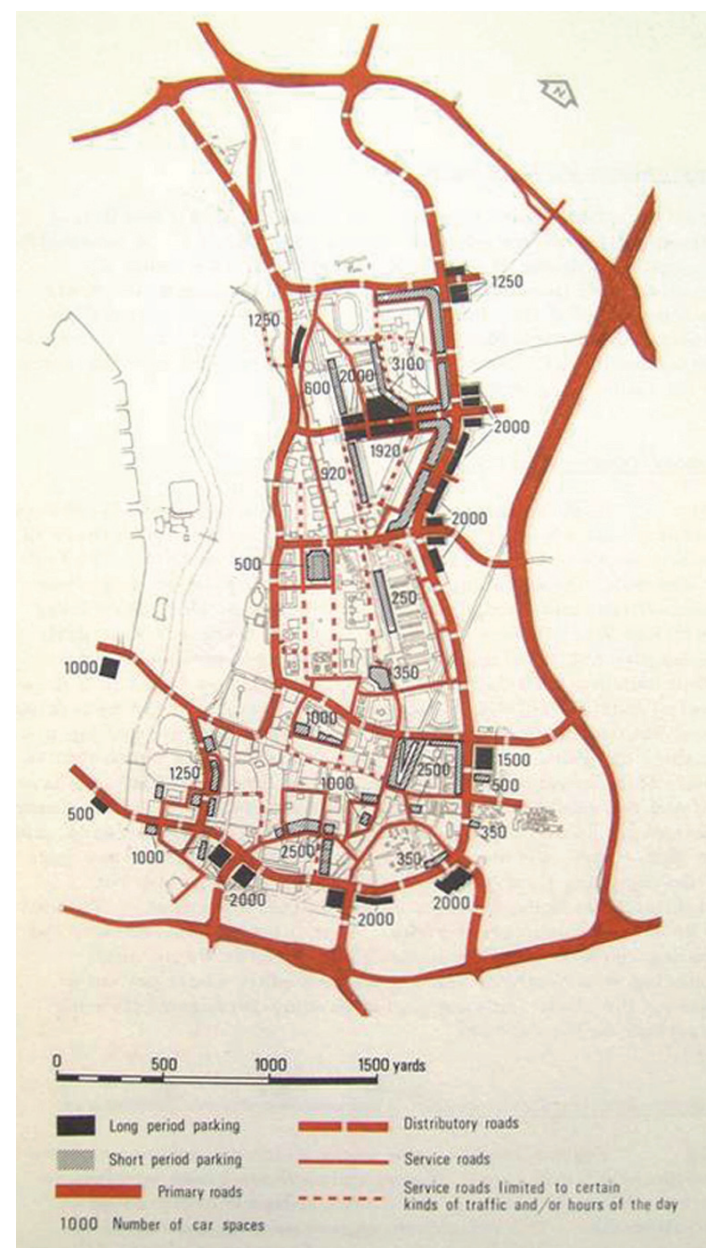

Figura 44: Plano para Cardiff: circulação viária e estacionamentos

Fonte: COLIN BUCHANAN\&PARTNERS, 1966: fig 32

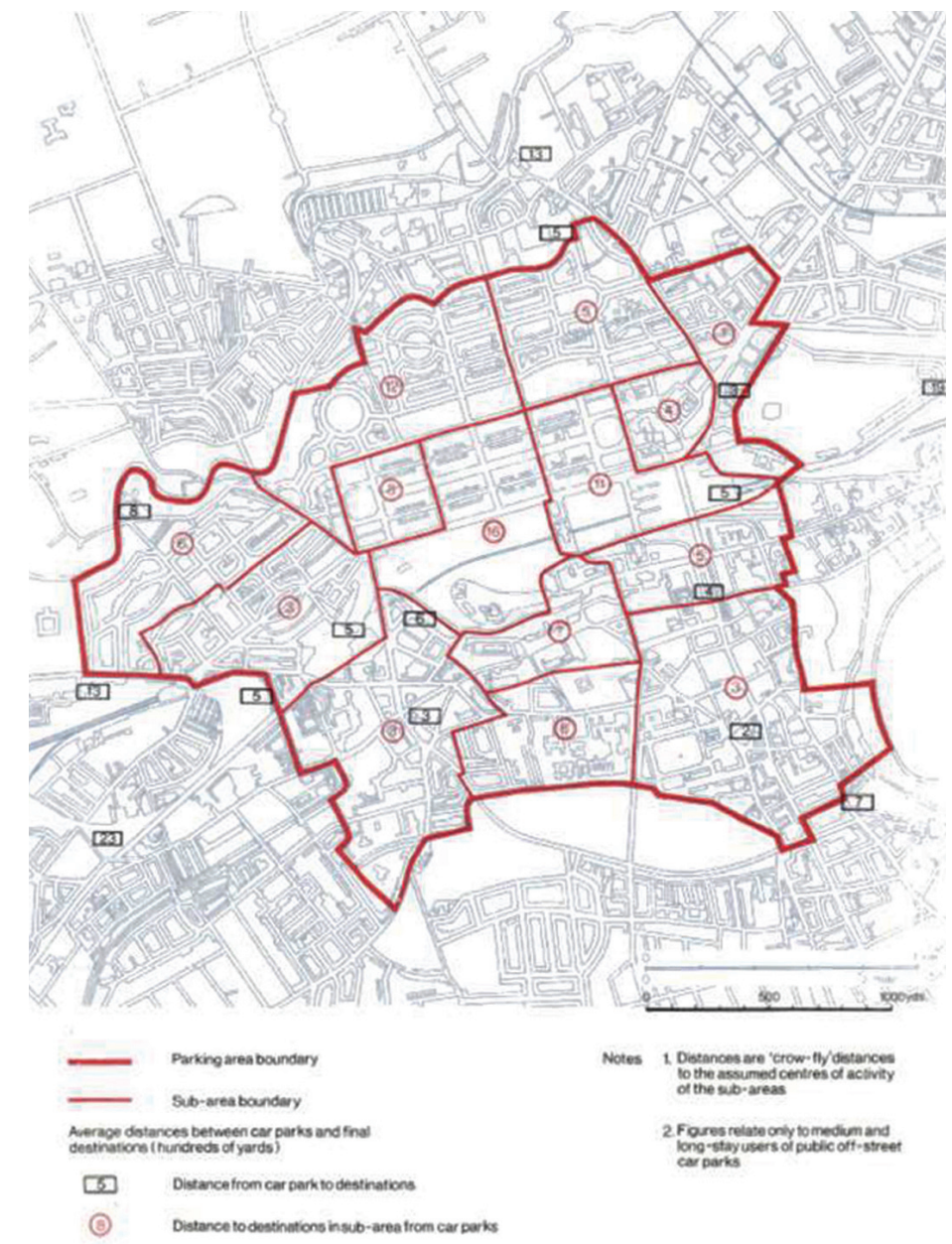

Figura 45: Distância média até os estacionamentos no centro de Edinburg

Fonte: COLIN BUCHANAN\&PARTNERS, 1972: fig 57 


\section{capítulo 5}

\section{A escala urbana local: a vizinhança e a rua}

Os anos 1960 podem ser caracterizados pela reavaliação das realizações modernistas no âmbito da cidade e também pelo fortalecimento da crítica a este urbanismo, sobretudo àquele divulgado pela vertente corbusiana. Autores como Jane Jacobs, Kevin Lynch, Aldo Rossi e Gordon Cullen, entre muitos outros constroem um vigoroso corpo teórico focado no desmonte dos preceitos urbanísticos modernos. Mesmo no âmbito dos CIAMs emergem visões contrárias ou renovadoras, como àquela formulada pelo grupo de arquitetos denominado Team $\mathrm{X}$.

De maneira geral, a questão da escala local - do bairro ou da vizinhança e da rua emerge como um dos pontos principais da discussão. Realizações como Chandigarh e Brasília permitiram visualizar resultados considerados indesejáveis do ponto de vista dos habitantes das cidades: perda de referencial urbano, isolamento, entre outros. Neste cenário, o desenho urbano ganha força como campo profissional para atuação de arquitetos.

Este esforço de resgate da qualidade do ambiente urbano e a emergência do desenho urbano como campo profissional tem para Colin Buchanan um significado particular. Para ele, esta era uma dimensão fundamental para a resolução do conflito entre accessibility e environment na escala local. Neste sentido, Buchanan formula dois conceitos centrais em sua 
obra: a noção de environmental areas, para abordar as questões relativas à escala do bairro, e o conceito de traffic architecture, para enfrentar as questões pertinentes à escala da rua.

Não por acaso, em Traffic in Towns, o engenheiro-urbanista monta uma equipe que conta com a presença de arquitetos e urbanistas, que desenvolveram uma pesquisa bem mais ambiciosa do que havia sido realizada por ele até então. Nesta ocasião, impressiona a sintonia entre as propostas do relatório e o debate que se processava naquele momento, tanto na Europa como nos Estados Unidos.

Buchanan não pode ser considerado como um formulador de novas idéias no campo do desenho urbano, mas sim como um observador atento do debate arquitetônico e urbanístico, assumindo vários dos conceitos discutidos naquele período da história em seus estudos e planos posteriores.

\section{A escala da vizinhança}

Em Traffic in Towns, Colin Buchanan desenvolveu mais intensamente suas preocupações com a afirmação de parâmetros que assegurassem condições ambientais satisfatórias na escala local, contra a presença indiscriminada dos veículos automotores no meio urbano. Neste sentido, o conceito de environmental areas, formulado na ocasião, foi algo extremamente relevante, contrapondo-se a duas fortes referências da tradição norteamericana: a engenharia de tráfego e os métodos de análise do tipo custo/benefício.

Por um lado, afirmava a necessidade de se considerar as pré-existências urbanas nos projetos de novas vias. Assegurava assim que os critérios de desempenho da engenharia de tráfego não deveriam ser os únicos parâmetros a serem considerados. Por outro lado, marcava uma posição de resistência em relação à metodologia de análise baseada no critério custo-benefício, que vinha sendo incorporada por economistas, traduzindo qualquer externalidade gerada pelos novos projetos em custos, portanto em critérios 


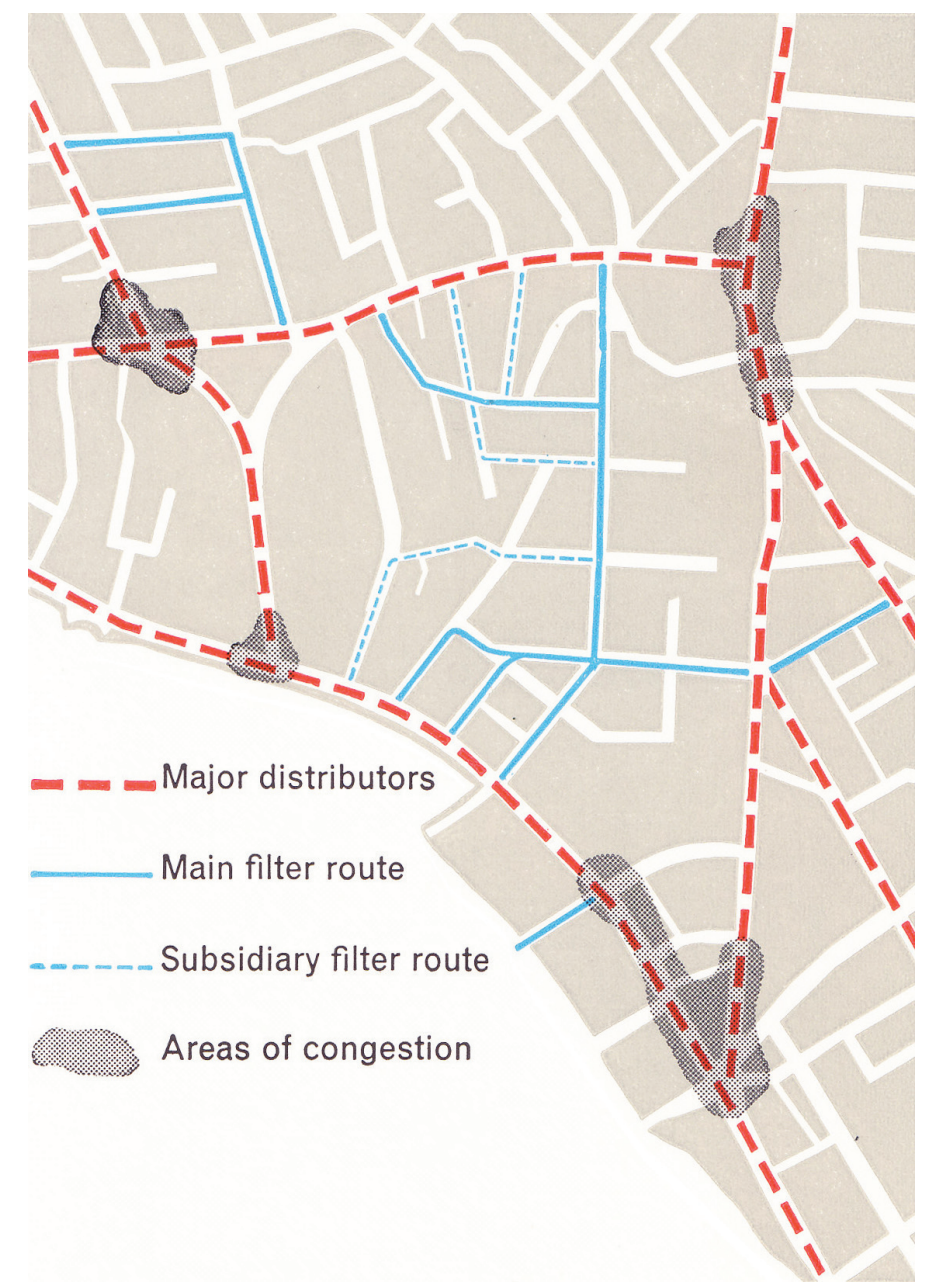

Figura 46: Problema da infiltração de tráfego em áreas residenciais

Fonte: BUCHANAN, 1963: 19 tangíveis. Para Buchanan, as questões relacionadas ao ambiente dificilmente se adaptariam a esta metodologia, uma vez que dificilmente se traduziam apenas em custos.

Peter Hall (2004) lembra que o então Ministro dos Transportes, Ernest Marples, contratou uma consultoria bi-nacional, formada por britânicos e norte-americanos, para análises conforme esta metodologia, simultaneamente ao desenvolvimento de Traffic in Towns. Às consultorias Freeman Fox e Wilbur Smith foi dada a incumbência de um estudo para a Grande Londres, empregando o método de custo/benefício. Assim, ao que parece, mesmo sem que houvesse plena clareza dos desdobramentos do conceito de environmental areas, a estratégia de Buchanan pretendia firmar uma posição, em que a questão urbana e ambiental assumia uma posição relevante no tratamento dos aspectos relacionados ao tráfego.

No conceito formulado em Traffic in Towns, as environmental areas seriam como os cômodos de uma casa, os locais onde as atividades domésticas se desenrolariam sem a interferência da circulação não relacionada às atividades daquele ambiente específico. Agrupadas em torno da noção de environment estavam todas as externalidades geradas pelo tráfego; mas, sobretudo as necessidades demandadas pelas cidades tradicionais, como Buchanan as conhecia no Reino Unido. Genericamente, é possível afirmar que as environmental areas eram uma forma de adaptação do tráfego à cidade existente. (HOUGHTON-EVANS, 1975)

Na dimensão da cidade, Buchanan as definiu da seguinte forma:

"(...) they are areas of groups of buildings and other development in which daily life is carried on, and where, as a consequence, it is logical that the maintenance of a good environment is of great importance." (BUCHANAN, 1963: 44)

A preocupação envolvida neste conceito residia na intenção de preservar do tráfego motorizado as áreas consideradas mais frágeis. O crescimento da frota e a insuficiência de capacidade do sistema viário existente, conforme Buchanan, geravam a tendência 
natural de dispersão do tráfego pela malha viária, particularmente junto aos pontos de restrição de capacidade do sistema viário estrutural.

Do ponto de vista da lógica de circulação, o conceito de environmental areas em Traffic in Towns pode ser considerado um desdobramento das idéias desenvolvidas por Alker Tripp alguns anos antes:

"Under this system a great number of "pockets" will be created, each of which will consist of a little local system of minor roads, devoted to industrial, business, shopping or residential purposes. These pockets are now known as "precincts", and all the loads within them will be local roads. The connections between the road system of the precinct and the sub-arterials should be comparatively few in number while giving adequate access. Precincts are the areas where the populace is housed and where shopping, business, industrial, amusement and recreational activities are carried on. It is essential that, all of these activities should be located in the precincts and kept clear of the sub-arterial (or arterial) roads: all roads in the precinct will be strictly local". (TRIPP, 1950: 332)

O conceito formulado por Tripp foi demonstrado utilizando como exemplo uma área central da cidade de Londres. As áreas identificadas pelas letras A, B e C conformariam os perímetros livres de tráfego de passagem, considerados como precincts. Ao mesmo tempo, havia a indicação de um sistema viário estrutural para abrigar os movimentos com origem e/ou destino situados fora dos precincts, além da implantação de uma série de elementos de mediação entre a escala local e a urbana, como as rotatórias e os semáforos.

Para Tripp, a questão principal não estaria nos padrões ambientais, como Buchanan acrescentaria ao seu discurso anos mais tarde, mas na incompatibilidade de convivência entre pedestres, ciclistas e veículos, particularmente em relação ao tráfego de passagem. A definição dos precincts, elaborada por Tripp, era fortemente calcada na sua grande preocupação com os acidentes de trânsito, fruto da sua experiência como gestor de tráfego em Londres.

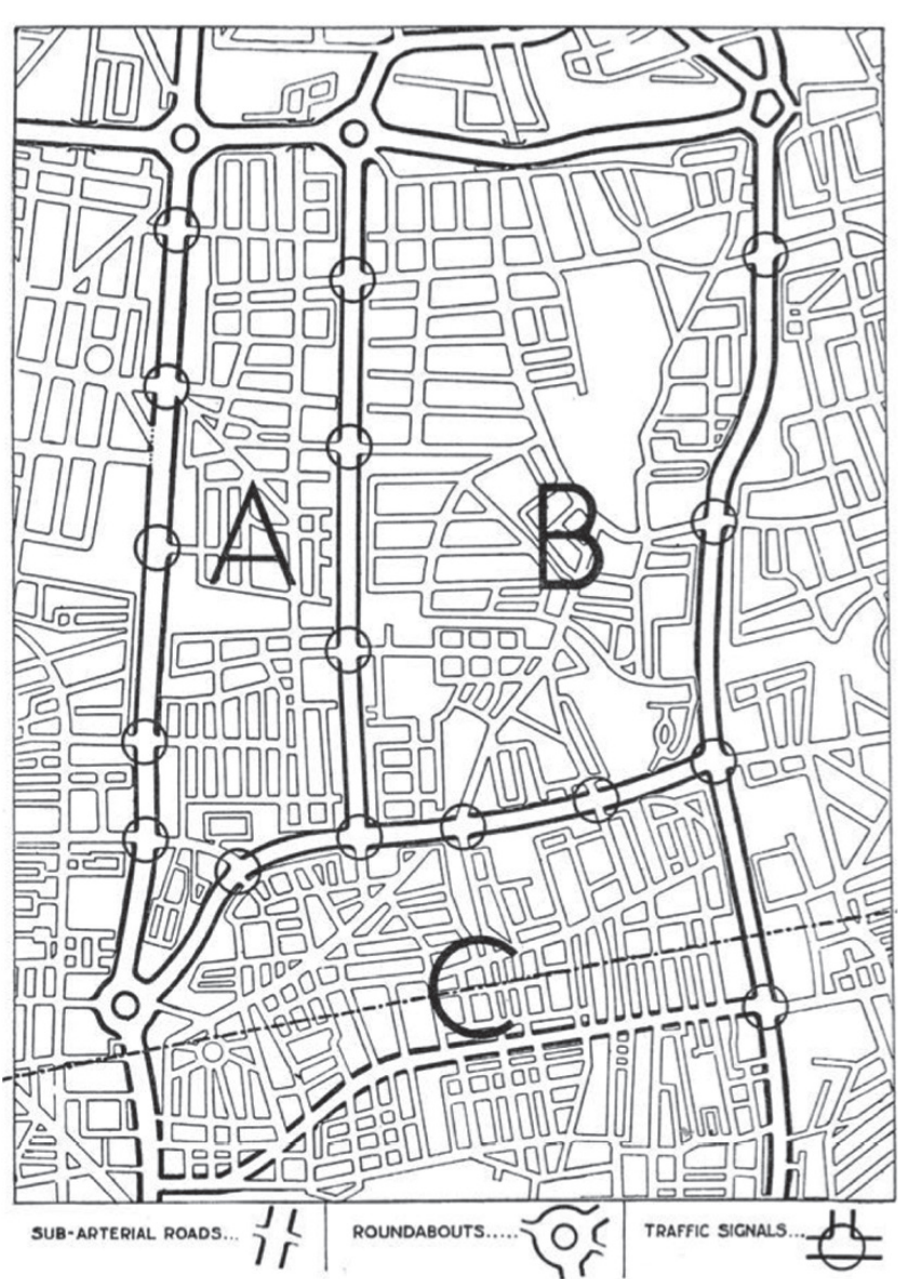

Figura 47: Conceito de "Precincts" segundo Alker Tripp Fonte: TRIPP, 1950: 334 
Ao defini-las simplesmente como áreas livres de tráfego de passagem, Buchanan assegurava que qualquer composição de usos do solo urbano fosse abarcada pelo conceito. As environmental areas poderiam ser compostas por usos mistos, unidades habitacionais, industriais, zonas comerciais e de serviços, etc; ou seja, qualquer parte da cidade poderia configurar uma unidade ambiental, conforme o relatório Traffic in Towns.

Para isto era definido um conceito auxiliar: o de capacidade ambiental, que vinculava as environmental areas a certos padrões ambientais, particularmente baseados na poluição sonora e sua relação com o volume de tráfego. Conforme Traffic in Towns, cada composição de usos nas environmental areas apresentaria tolerâncias diferentes em relação aos níveis de ruído. As predominâncias de usos industriais, por exemplo, apresentariam maiores possibilidades de convivência com patamares de ruído mais intensos.

O relatório, no entanto, não definia estes limites, apenas mencionava que o nível ideal seria aquele que permitisse uma situação de conversação tranqüila entre os seus habitantes. O foco estaria na fonte geradora e não na tecnologia veicular como uma possível solução. Assim, a ação deveria recair sobre a limitação do volume de tráfego.

Segundo Buchanan, a delimitação das environmental areas no espaço urbano atenderia a um critério aparentemente simples: a circulação motorizada no seu interior não poderia contar com o tráfego de passagem. Em outras palavras, somente o volume de tráfego gerado por suas atividades internas seria admitido, limitando a geração de poluição sonora.

Esta definição exigia a tarefa de quantificação do volume de tráfego gerado pelas atividades urbanas das environmental areas; o que não se configurava como um grande desafio. A definição de standards baseados nos tipos de atividades poderia definir facilmente os volumes gerados.

No entanto, o procedimento de configuração espacial das environmental areas parecia mais complexo do que defendia Buchanan. No confronto com situações reais, este conceito 
resistia a uma definição puramente quantitativa, baseada exclusivamente no volume de tráfego que poderia ser assimilado pela área.

A análise dos trabalhos de consultoria empreendidos em meados dos anos 1960 mostra que as definições das environmental areas se iniciavam a partir de uma análise da morfologia e da dinâmica das atividades urbanas e só depois eram aplicados os conceitos de capacidade de tráfego. Mesmo esta análise, de natureza urbanística, não apresentava uma linha clara de raciocínio.

A delimitação das environmental areas se realizava ora pela identificação de áreas degradadas; ora por regiões organizadas a partir de vias de conexão com centro; ora pela configuração de áreas com patrimônio histórico relevantes; ora pela área configurada por meio de vias estruturais, ora pela imposição de limites físicos, como rios ou o relevo; ou ainda pela delimitação de unidades com características urbanas similares, que poderiam ser traduzidas como bairros, por exemplo.

O Estudo de Desenvolvimento Urbano e Transportes para Cardiff, no Reino Unido, é um exemplo revelador da diversidade de procedimentos na delimitação destas areas. A sequência de mapas utilizada na definição destes limites nos fornece elementos interessantes de análise. O procedimento se iniciava pela delimitação de áreas com desenvolvimento urbano insatisfatório. Tal identificação não se fazia pela definição de uma única mancha urbana, que ao final corresponderia a parte significativa da área mais central. Ao contrário, já incorporava determinados limites urbanos; que, em grande parte, foram assumidos posteriormente como limites das environmental areas.

A fase seguinte se concentraria na definição de possíveis limites, a partir de uma análise morfológica e funcional das áreas urbanas. Só a partir de então. a verificação dos volumes de tráfego seria incorporada como elemento da análise. Por esta razão, a indicação de alguns dos limites era apenas uma possibilidade. O resultado era então um mapa que definia os limites das environmental areas, indicava as vias em que o volume de tráfego deveria ser controlado e apontava as possíveis vias estruturadoras.

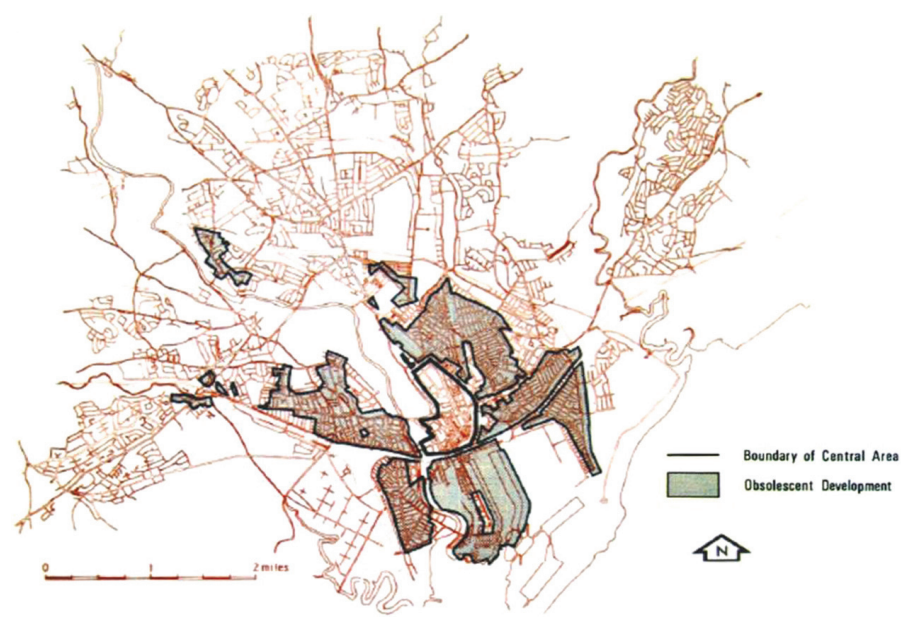

Figura 48: Cardiff: Development and Transport Study, Colin Buchanan\&Partners, 1966 - identificação da área central e áreas degradadas

Fonte: COLIN BUCHANAN\&PARTNERS, 1966: fig 10

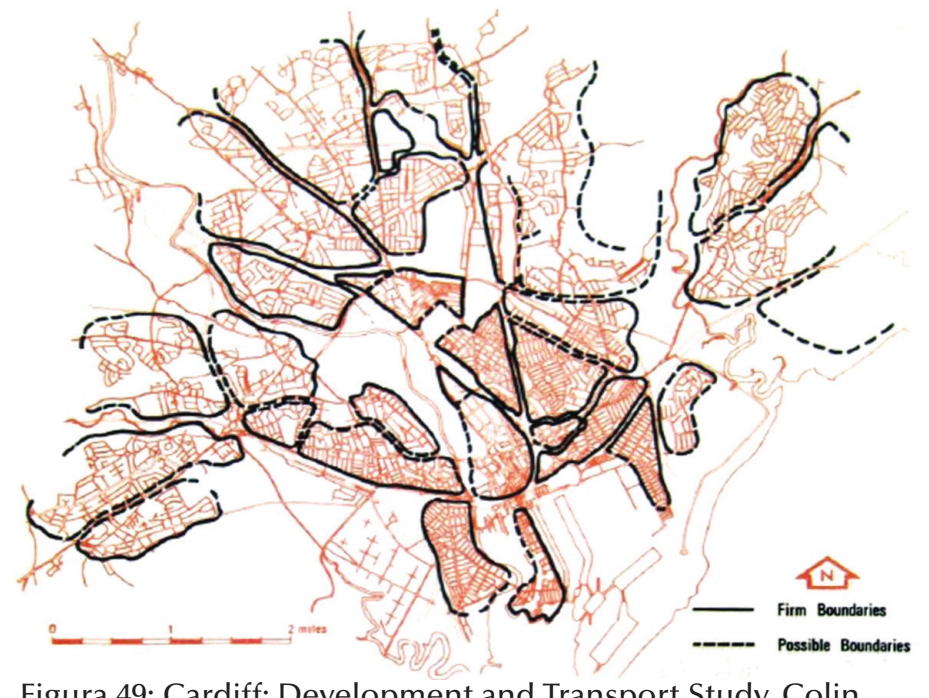

Figura 49: Cardiff: Development and Transport Study, Colin Buchanan\&Partners, 1966 - identificação preliminar das environmetal areas

Fonte: COLIN BUCHANAN\&PARTNERS, 1966: fig 11 


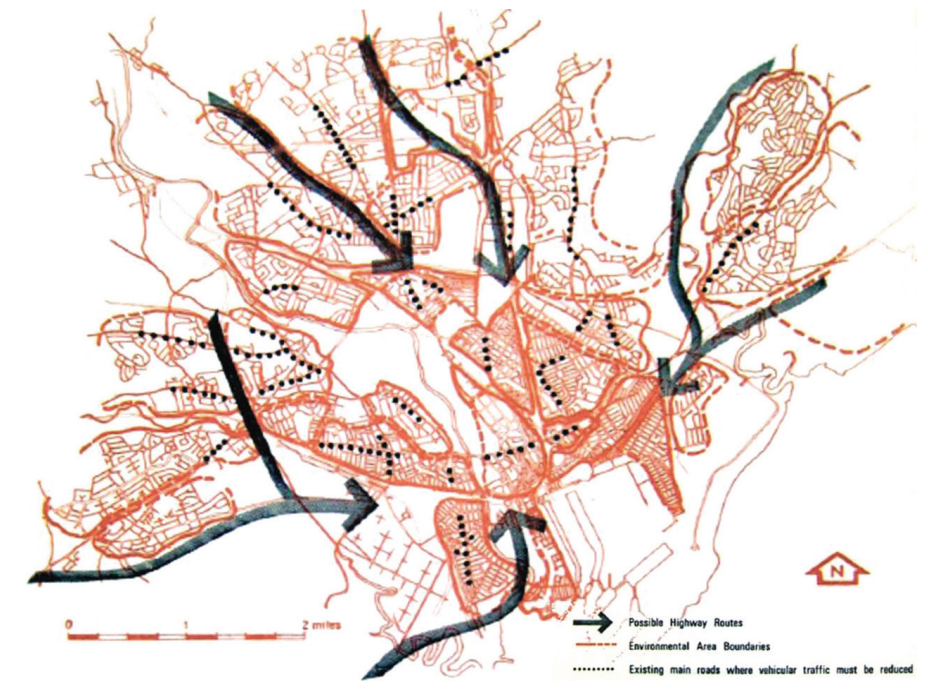

Figura 50: Cardiff: Development and Transport Study, Colin Buchanan\&Partners, 1966 - identificação das environmental areas e estabelecimento de diretrizes para sistema viário estrutural

Fonte: COLIN BUCHANAN\&PARTNERS, 1966: fig 1
A análise morfológica e funcional, no entanto, se fazia a partir de raciocínios diferentes. Nas regiões sudoeste e nordeste de Cardiff, os limites foram estabelecidos por características morfológicas, indicando a conformação de bairros. Em boa parte das outras áreas na periferia da cidade, as environmental areas foram configuradas a partir de regiões polarizadas em torno de vias de conexão com o centro da cidade.

O Estudo para Cardiff identificava várias environmental areas onde vias do seu interior deveriam ter seu volume de tráfego reduzido. Via de regra, estas ruas e avenidas se configuravam como conexões entre a periferia e o centro da cidade, estruturando a expansão da mancha urbana. Este volume de tráfego excedente deveria então ser transferido para canais de maior capacidade, a serem construídos ou ampliados.

Neste aspecto, o conceito proposto em Traffic in Towns era bastante controverso. A preocupação de preservar o "ambiente" do tráfego de passagem parecia não considerar a relação essencial entre a circulação e as atividades comerciais e de serviços estabelecidas ao longo da vias. Em outras palavras, ao diminuir o volume de tráfego nas vias radiais, esta estratégia poderia comprometer a viabilidade da dinâmica urbana estabelecida.

Neste sentido, Buchanan exacerbava sua intenção de completa separação em accessibility e environment. A partir da configuração final proposta para a cidade de Cardiff, circulação e ambiente ocupariam espaços urbanos completamente distintos e não permeáveis, numa clara intenção de concentrar os volumes de tráfego em poucas vias.

Outra questão controversa do conceito de environmental areas diz respeito à dificuldade de assimilação das transformações de uso do solo, inerentes a qualquer dinâmica urbana. De fato, estabelecidos os limites destas áreas qualquer alteração na composição de usos e sua conseqüência na geração dos volumes veiculares teria grande dificuldade de ocorrer de maneira natural. Os limites das environmental areas eram rígidos e a própria dinâmica da cidade estaria condicionada a um conceito bastante ligado ao tráfego, desconsiderando outras dinâmicas que se processam. 
Buchanan, ao comentar rapidamente as possíveis transformações urbanas posteriores à definição dos limites das environmental areas, alega que estas estariam sujeitas à disponibilidade de investimentos para a adequação da escala urbana. Embora esta fosse uma forma de solução da questão, desconsiderava, por exemplo, o fato que os novos canais de tráfego previstos, seriam naturalmente eixos de atração de atividades comerciais e de serviços.

Não deixa de chamar atenção também a exclusão dos transportes públicos do discurso sobre as environmental areas. Embora os ônibus não tenham sido esquecidos em algumas ilustrações sobre o rearranjo de parte da área central de Londres, nos textos não há menção aos modos públicos. Ellen (1967) afirma que, enquanto o automóvel é parte do "ambiente", o ônibus aparentemente não é.

O procedimento de definir as environmental areas pelo volume de tráfego não parece por acaso. Ao defini-las pela quantidade de tráfego o engenheiro urbanista garantia sua adequação ao objeto do relatório Traffic in Towns. Como declarara desde o início, era apenas um estudo sobre os desafios e as potencialidades do uso do automóvel.

Mas, por outro lado, esta estratégia tinha também como característica o fato de, discretamente, apontar um ponto de discordância com seus colegas da Town and Country Planning Association, que eram francamente partidários do conceito de "unidades de vizinhança" e do ideário da Cidade Jardim. Buchanan declarou enfaticamente no relatório Traffic in Towns que não havia nenhuma relação entre as environmental areas e qualquer conceito sociológico, nem com a idéia de precincts, muito menos com o conceito de unidade de vizinhança (BUCHANAN, 1963).

No entanto, ao contrário de seus esforços, a definição da idéia de precinct, presente na literatura de urbanismo daquele momento, parece muito próxima daquela que desenvolveu para as environmental areas. Frederick Gibberd ${ }^{29}$, por exemplo, formulara uma

29 A edição de 1953 de "Town Design" de Fredderick Gibberd consta da bibliografia de Mixed Blessing, de Colin Buchanan. 
conceituação bastante similar a de Buchanan, sendo também calcada na questão da eliminação do tráfego de passagem, e que seria denominada justamente como precinct:

“(...) Having defined the precinct, all internal roads that give through acess, or which do not serve a useful purpose, are closed and given over either to the pedestrian, to building space, or to car parking. Conflicting building uses are removed from inside the area, and a new layout is devised to form special settings for the existing and new buildings, and to give priority to the pedestrian" (GIBBERD, 1962: 65-66).

Mais adiante, Gibberd complementaria:

"The word 'precinct' is often used to mean a space in which motor-cars are strictly excluded, and certainly in so far as a shopping precinct is concerned, that is its exact meaning. Nevertheless, in most precincts there must be some service roads and we shall avoid ambiguity if we describe the precinct as an area of buildings in which through motor traffic is excluded." (GIBBERD, 1962: 67) (grifo nosso)

Mesmo Alker Tripp, uma importante referência para Buchanan, embora abordando quase exclusivamente as questões de tráfego em seu livro, alerta que o conceito de precint não era inédito, sendo largamente difundido no Reino Unido. De fato, o conceito havia se tornado uma espécie de "unidade de planejamento" na prática britânica de urbanismo (HOUGHTON-EVANS, 1975).

Além disso, dificilmente é possível desvincular o conceito de environmental areas do debate urbanístico de revisão do Movimento Moderno nos anos 1950 e 1960. Neste período, o Team X estava justamente inserindo na discussão a idéia de comunidade em contraposição à noção de universalidade dos preceitos modernos de urbanismo, redirecionando o foco para condicionantes locais e culturais da cidade (BARONE, 2002).

Partindo da noção de comunidade, o Team X propunha ainda a organização da cidade por meio de clusters ou agrupamentos, como forma de agregação de unidades a partir 
de um raciocínio unificador. Barone, comentando este assunto, ressalta:

"Para eles, o objetivo central do urbanismo era tornar claros os padrões de organização do espaço, no sentido de facilitar a criação de relações de identidade e associação do homem com a cidade. A noção de cluster tinha como objetivo tornar compreensível a idéia da comunidade e das partes que a formam, como grupos visuais inter-relacionados, constituídos de associações de unidades". (BARONE, 2002: 81)

A relação entre os conceitos de cluster e de environmental areas é sugestiva. Ambos pressupõem uma lógica composta por unidades que se vinculam a um raciocínio ordenador. No caso de Buchanan, o sistema viário seria o principal elemento organizador.

Por outro lado, chama atenção também a proximidade do conceito de environmental areas com o discurso contemporâneo de Gordon Cullen. Para o arquiteto britânico haveria que se resgatar a "Arte do Meio Ambiente", que supõe a "participação emocional das pessoas" como cerne da questão urbana (CULLEN, 2009: 17). No entanto, é a proximidade com a noção de "recinto" que mais chama atenção:

"O recinto é uma síntese da polaridade entre pés e pneus, i.e., entre a circulação de pessoas e veículos. É a unidade base duma certa morfologia urbana. Fora dele, o ruído e o ritmo apressado da comunicação impessoal, vai-vem que não se sabe para onde vai nem donde vem: no interior, o sossego e a tranqüilidade de sentir que o largo, a praceta, ou o pátio têm escala humana. O recinto é o objetivo da circulação, o local para onde o tráfego nos conduz. Sem ele, o tráfego tornar-se-ia absurdo" (CULLEN, 2009: 27).

Embora Colin Buchanan ressaltasse a desvinculação do conceito de environmental areas da tradição urbanística britânica de valorização da dimensão comunitária, a questão em jogo neste caso só se resolveria plenamente três anos após Traffic in Towns, no Estudo para South Hampshire, em $1966^{30}$. Buchanan já neste momento apontava o que, ao que parece, seria a inviabilidade do conceito de Cidade Jardim e seus desdobramentos na condição

30 Ver capítulo 6 
de cidade na era do automóvel. Não por acaso, o periódico Town and Country Planning, uma espécie de porta voz do movimento Cidade Jardim, divulgou seguidos artigos criticando o relatório de Buchanan, logo após sua publicação (THOMAS, 1964; HODGE, 1964)

Em paralelo, como visto no Capítulo 2, Buchanan não estava desvinculado da crítica ao conceito de unidade de vizinhança e da nação de precinct que se processava no debate britânico, por conta da segunda geração de New Towns. Mais uma vez, a dimensão urbana da noção de environmental areas parecia se afirmar, ao contrário do que buscava demonstrar o engenheiro-urbanista britânico.

Ao final, a discordância de Buchanan se concentrava em praticamente uma única característica. Enquanto as noções de precinct e unidade de vizinhança implicavam em autonomia destes núcleos em relação ao exterior, pois eram configuradas a partir de vias que definiam barreiras muito claras; no conceito formulado por Buchanan, cada environmental area poderia relacionar-se com outras adjacentes. Neste caso, era a escala do projeto urbano, como veremos a seguir, que mediava esta relação.

\section{A escala da rua}

O vertiginoso aumento da frota de automóveis e a política de construção de um sistema viário adaptado à demanda tiveram também um desdobramento sobre o caráter histórico da rua. Pode-se admitir que este elemento urbano atingiu um momento de crise nos anos 1950 e 1960, em relação ao seu papel na cidade. Buchanan, em palestra em São Paulo em 1967, afirmou: “(...) O movimento motorizado eliminou a rua como elemento básico de projeto da malha urbana, e isto é um assunto sério para a cidade." (BUCHANAN, 1966: 14)

A rua agora era concebida como canal de circulação de veículos automotores, que exigia sua completa remodelação e afastava outras funções que ela acumulava na cidade 
tradicional, como lugar de encontro e de pedestres. Neste caminho, contribuíam juntas a engenharia de tráfego norte-americana e a vertente corbusiana de urbanismo. Ambas valorizavam os aspectos da eficiência da via como meio de circulação de automóveis.

Para Stephen Marshall a via urbana acumulava até então três papéis físicos diferentes:

“(..) that of circulation route, that of public space, and that of built frontage. These three elements may be loosely equated with linear concern of the transport engineer (the street as a one-dimensional 'link' in the traffic network), the planar concern of the planner (streetspace as land use) and the three-dimensional concern of the architect or urban designer" (MARSHALL, 2005: 6)

Mais adiante complementa, fazendo uma brilhante análise da situação a partir dos anos 1950 e 1960 :

"However, the revolucionary rhetoric of Modernism passed a death sentence on the street. Modernism set up a new urban model that liberated the forms of roads and buildings from each other. Rather than being locked together in the street grids, the Modernist model allowed roads to follow their own fluid linear geometry, while buildings could be expressed as sculped three-dimensional forms set in flowing space. Each form could follow its own dedicated function, resulting in a divergence of forms and quite separate geometries for buildings and roads. The street, in offcial vocabulary, ceased to exist." (MARSHALL, 2005: 6-7)

Não por acaso, o texto da Carta de Atenas era incisivo: “(...) From then on, the house will never again be fused to the street by a sidewalk" (LE CORBUSIER, 1973: 57). Há de fato, uma nova lógica de construção da cidade, que separa os sistemas de espaços dos sistemas de circulação, ao contrário da cidade tradicional, onde os edifícios, largos e outros elementos urbanos formam um sistema conjunto com a rua (ELLIS, 1981).

Novamente é Marshall (2005) que nos ajuda a compreender o processo de transfor- 
mação na concepção da rua, sobretudo nos anos 1950 e 1960. O autor propõe uma tipologia, denominada "ABCD”, em que o tipo A seria característico de áreas antigas, particularmente intra muros, indicando ainda um certo caráter radial, embora rudimentar. O tipo B seria típico das expansões urbanas do século XIX. Ambos pertenceriam a era do transportes não motorizados. $\mathrm{O}$ tipo $\mathrm{C}$ seria característico das expansões suburbanas, baseadas em vias arteriais radiais, enquanto o tipo $\mathrm{D}$ traria fortemente um caráter moderno e até mesmo anti-urbano. Ao contrário dos dois primeiros, os tipos $\mathrm{C}$ e D pertenceriam a era dos transportes mecanizados.

$\mathrm{Na}$ cronologia proposta por Marshall, mostrada como uma sequência de expansões urbanas do centro para a periferia, fica evidente que a via foi progressivamente se especializando. O tipo A supõe acúmulo de funções urbanas, enquanto o tipo D se caracteriza pela distinção entre vias para o melhor desempenho do tráfego e vias de acesso aos lotes.

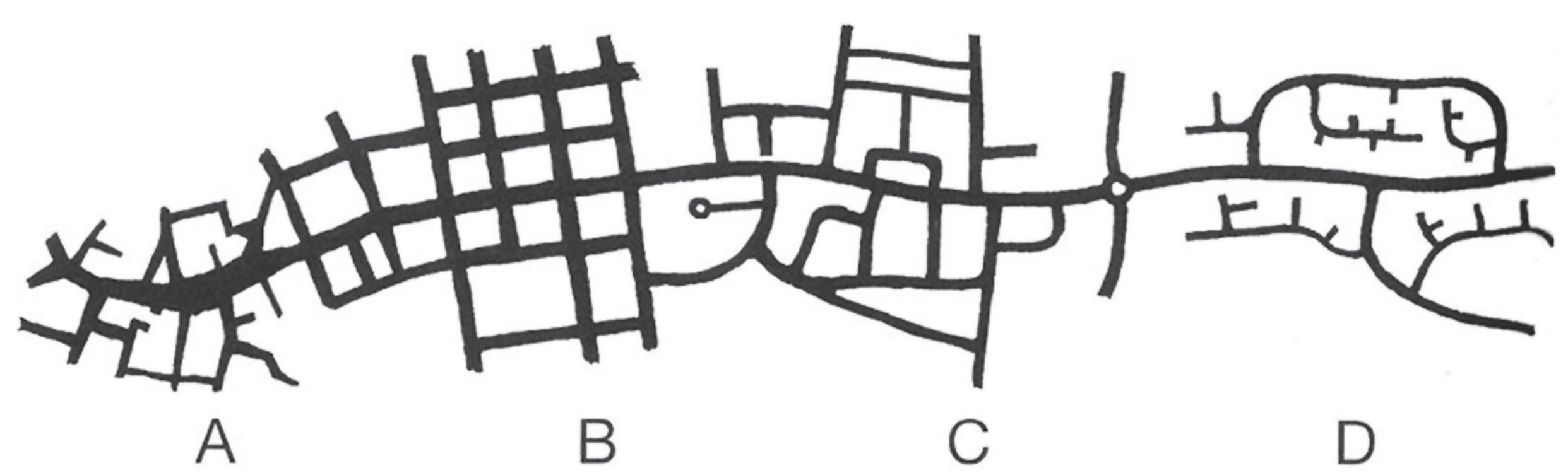

Figura 51: Tipologia $A B C D$ de sistema viário Fonte: MARSHALL, 2005: 84 
A situação norte-americana neste momento se constituía na forma mais acabada da proeminência da rua como canal de tráfego, tendo sido muitas vezes mencionada por Colin Buchanan. Pode-se dizer que a engenharia de tráfego naquele país traduziu para o campo prático o discurso modernista da rua e o difundiu na forma de manuais de projeto de vias. Particularmente, Nova Iorque e seu extenso programa de construções de vias expressas, gerenciado pela figura poderosa de Robert Moses, capitaneava uma legião de cidades norte-americanas na sua transformação em prol do automóvel.

As críticas a este modelo nos anos 1950 e 1960 não tardaram a denunciar a crise da rua como espaço público. Gordon Cullen (2009) ressaltava que o padrão tradicional das vias estava em extinção. Nos Estados Unidos, Jane Jacobs argumentava:

"As ruas das cidades servem a vários fins além de comportar veículos; e as calçadas - a parte das ruas que cabe aos pedestres - servem a muitos fins além de abrigar pedestres. Estes usos estão relacionados à circulação, mas não são sinônimos dela, e cada um é, em si, tão fundamental quanto a circulação para o funcionamento adequado das cidades". (JACOBS, 2001: 29)

Não por coincidência, neste período se constituiu o desenho urbano como preocupação específica de arquitetos e urbanistas, frente ao que Kevin Lynch chamou de “(...) result of the fragmentation of Modernist city planning and its new, 'scientific', nonphysical, statistical, mathematical modeling techniques, which made the physical form of the city almost irrelevant" (SHANE, 2005: 59).

Se de um lado se afirmava claramente uma corrente de revalorização da cidade tradicional, do outro o próprio Movimento Moderno tecia sua revisão interna, curiosamente a partir da obra de ninguém menos que Le Corbusier. Conforme Reis Fillho, a Unidade de Habitação de Marselha, projetada pelo arquiteto franco-suíço, indicava uma outra solução formal para a questão da multiplicidade de funções urbanas da rua, que ele mesmo havia destituído: a verticalização dos conflitos que naturalmente ocorriam nas ruas tradicionais. Para Reis Filho, os planos para as New Towns de Hook e Cumbernauld

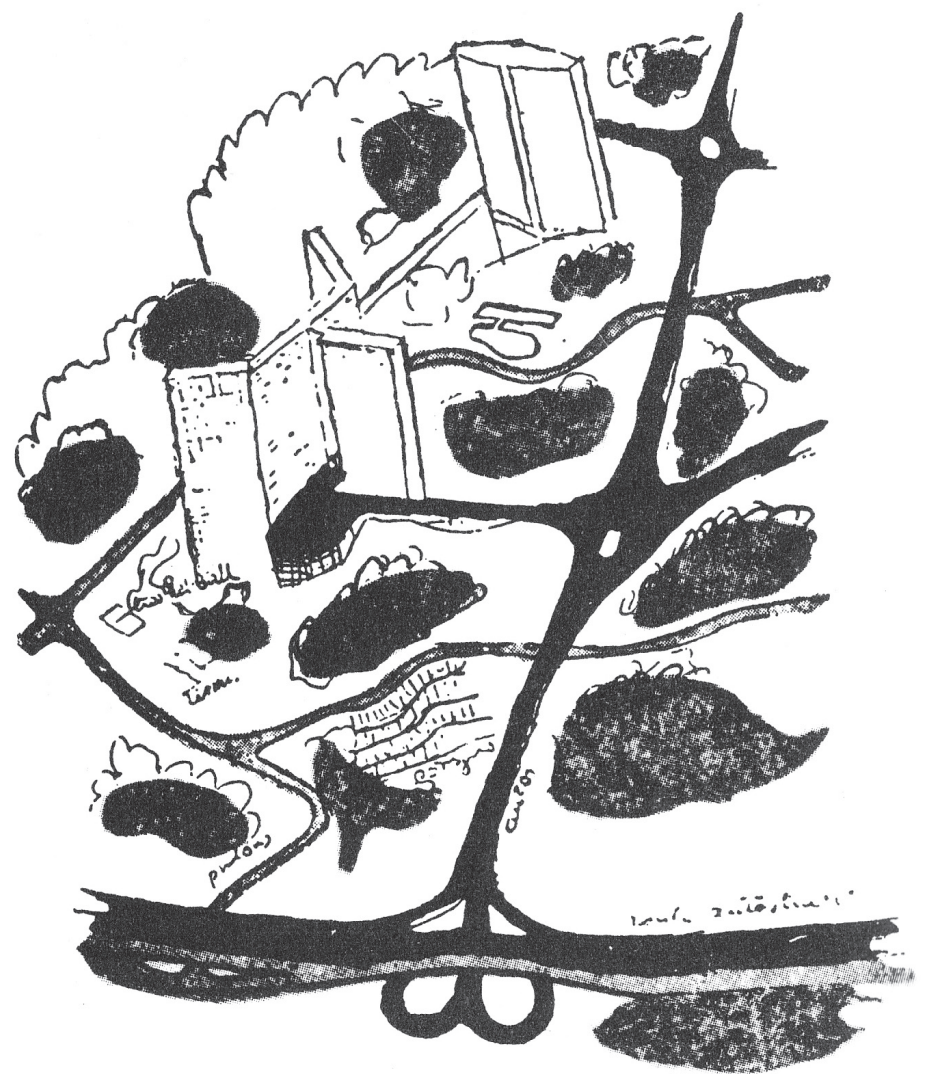

Figura 52: Exemplo de uma implantação urbana e seu sistema viário, conforme Le Corbusier Fonte: LE CORBUSIER, 1971: 86 
“Retomam (...) as ruas para pedestres dos edifícios de Le Corbusier, que transformam em decks, como ruas largas, junto ao exterior, para o qual são abertas e com suas articulações valorizadas por verdadeiras 'praças'. A intenção era transpor para o sentido vertical a trama espacial e social da rede viária horizontal”. (REIS FILHO, 1967: 70)

Os dois planos mencionados acima, como vimos no capítulo 2, certamente influenciaram muito as concepções de Colin Buchanan na época da elaboração do relatório Traffic in Towns. No entanto, esta referência parece ter seguido um caminho mais complexo que a conexão França-Reino Unido. Curiosamente, vieram dos Estados Unidos duas experiências que tiveram bastante repercussão não só na obra de Buchanan, mas de boa parte do planejamento Britânico: o projeto para Forth Worth e para a área central de Filadélfia.

Houghton-Evans (1975) lembra que as resoluções projetuais empregadas em Cumbernauld não se tratavam propriamente de uma novidade. Para ele, neste momento, este tipo de configuração já estava bastante difundido. Anteriormente a solução tinha sido empregada no projeto para Forth Worth, no Texas (EUA), em $1956^{31}$.

Buchanan elaborou comentários a este projeto antes mesmo de Traffic in Towns, em 1958, no seu primeiro livro. Segundo ele, Forth Worth apresentava soluções muito interessantes no que diz respeito às vias elevadas de pedestres e à completa restrição dos automóveis na área central da intervenção. Mas, neste momento, advertia também sobre o porte e os custos deste tipo de solução.

Do mesmo período, o plano de Luis Kahn para a área central de Filadélfia (EUA) seria a segunda referência, esta ainda mais poderosa, para o urbanismo Britânico. Não só as idéias de Kahn, mas também os desenvolvimentos projetuais elaborados pela municipalidade, posteriormente seriam observados com bastante atenção por Colin Buchanan. Neste caso, a solução partia para uma complexa articulação vertical de funções, prevendo estacionamentos suspensos e a sobreposição de diferentes modais de transportes.

31 Jacobs (1966: 11-12) críticaria também a separação dos conflitos da rua em níveis diferentes. Para ela, estas soluções seriam demasiadamente engenhosas e caras e com um fim em si mesmo. 


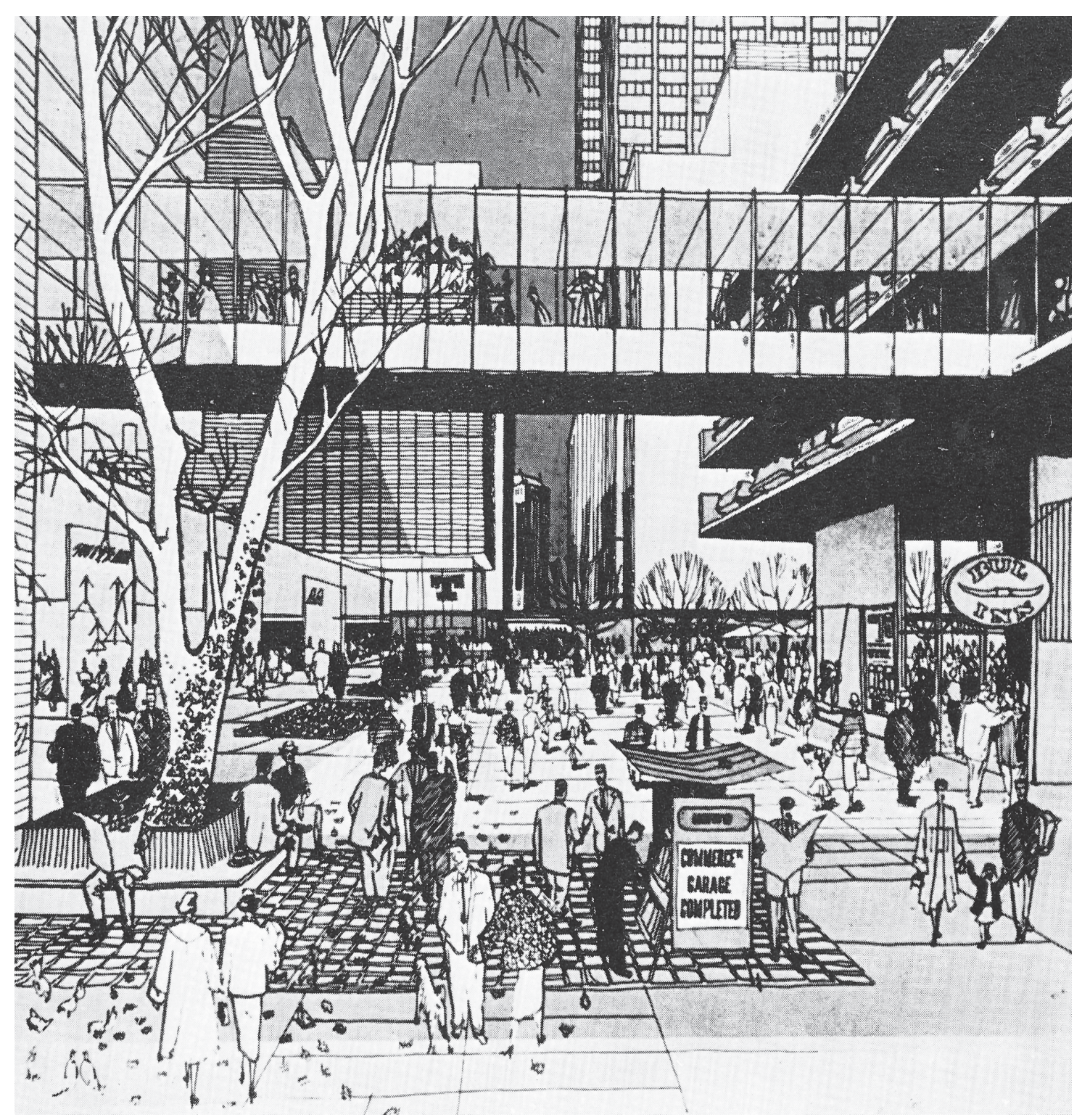

Figura 53: Projeto para Fort Worth, Texas, EUA - Victor Gruen Associates, 1956 - Perspectiva da Rua de Pedestres.

Fonte: BUCHANAN, 1958: plate XLVII

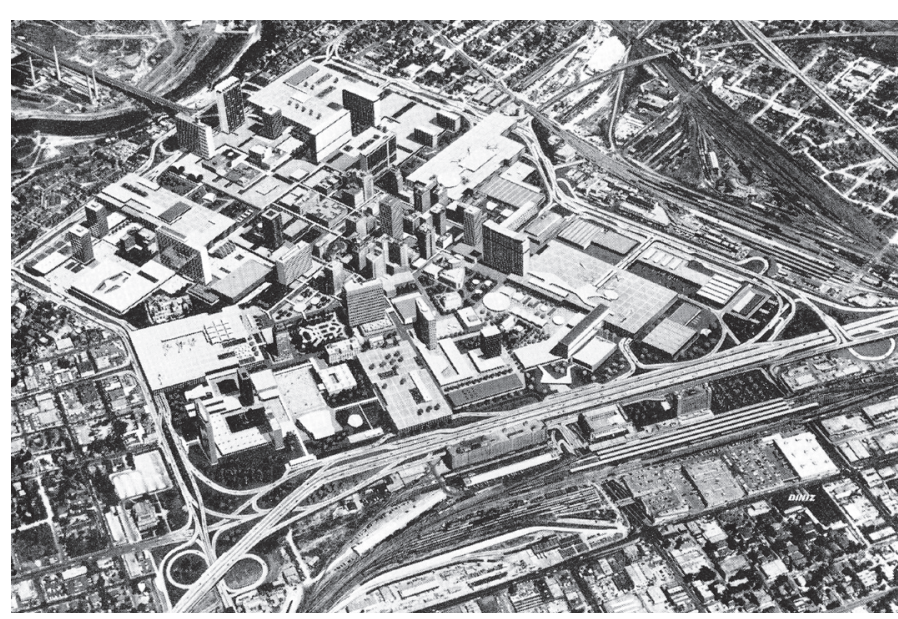

Figura 54: Projeto para Fort Worth, Texas, EUA - Victor Gruen Associates, 1956 - Modelo da Implantação Fonte: BUCHANAN, 1958: plate XLVI 
A obra de Louis Kahn foi uma referência particularmente intensa para as teses projetuais defendidas pelo grupo de arquitetos europeus, conhecido como Team X. Já no CIAM de Aix-en-Provence, esse grupo de jovens arquitetos (Candillis, Bakema, Van Eyck e os Smithsons)

“criticam os princípios que presidem as formulações teóricas resultantes das reuniões precedentes, da Carta de Atenas de 1941 ao relatório efetuado por Sert sobre o CIAM de 1951 dedicado ao 'coração da cidade', e apresentam seus primeiros projetos importantes Alexanderpolder e o Golden Lane, baseados numa abordagem de conjunto da realidade do ambiente urbano". (BENEVOLO, 2009: 13).

Particularmente, interessa neste caso ressaltar a atenção especial à mobilidade, por meio de soluções que verticalizavam os conflitos presentes nas ruas tradicionais. Para os Smi-

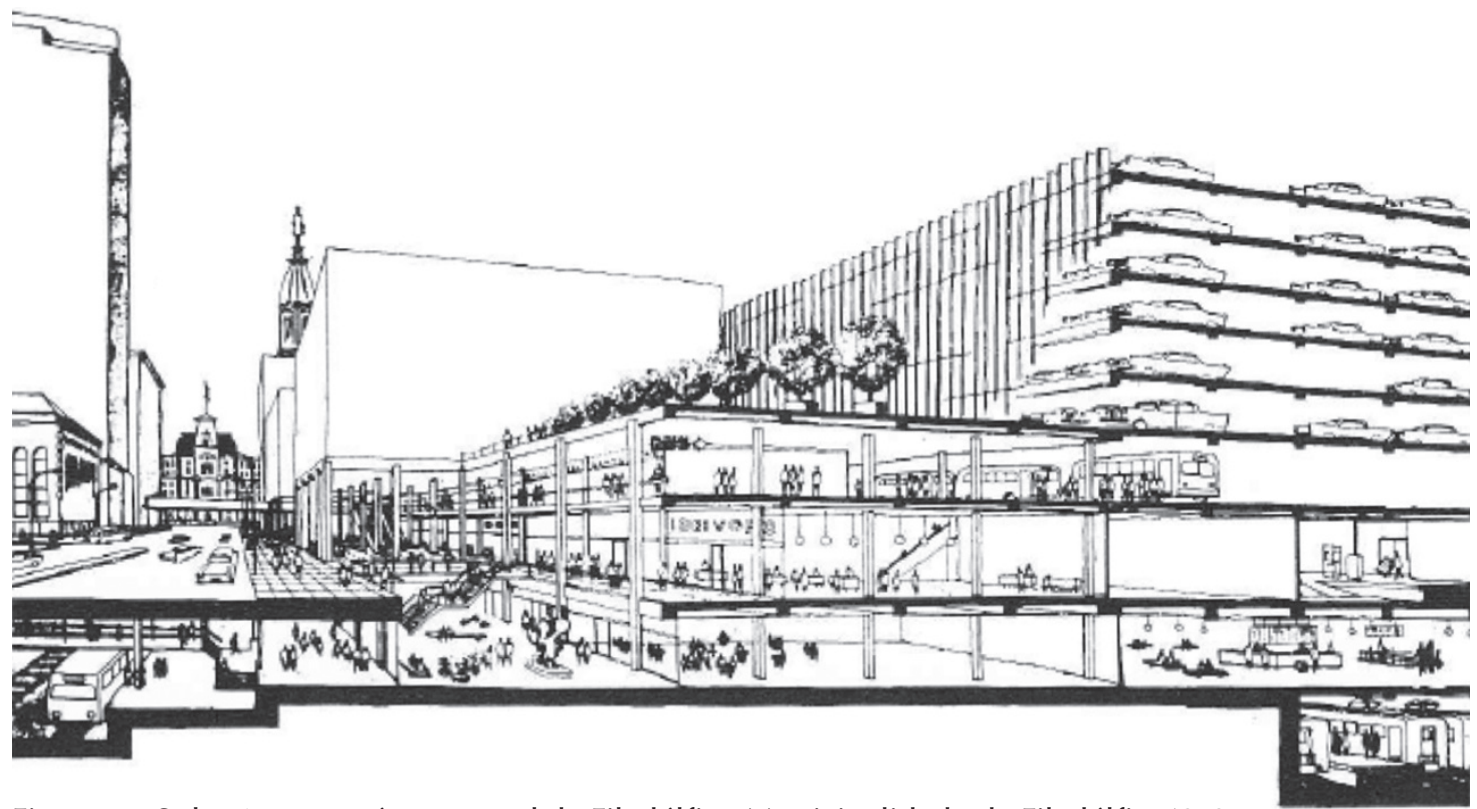

Figura 55: Solução para a área central de Filadélfia - Municipalidade de Filadélfia, 1959 Fonte: DOXIADIS, 1968: 498 
thsons esta questão se realizaria com bastante ímpeto no projeto para o concurso para Berlin Hauptstadt, de 1957. A rua, neste caso, se desdobraria numa arquitetura de vários níveis independentes.

Alguns anos depois, Peter Smithson, comentando o novo papel do sistema viário, argumenta:

"Para o arquiteto isto não é somente um problema de tráfego; para ele é concebido como a invenção de tipos de edifícios apropriados para o novo padrão urbano de demandas motorizadas" (SMITHSON, 1968: 48)

De fato, tais experiências apontam não uma ruptura com a imagem de cidade divulgada por Corbusier, mas sim uma revisão, baseada nos próprios desdobramentos da obra do arquiteto franco-suíço. Se o projeto para a Unidade de Habitação de Marselha era um elemento de fundo neste discurso da verticalização dos conflitos da rua, era também verdade que havia um elemento novo neste cenário: a escala da rua como uma dimensão específica do projeto arquitetônico.

Colin Buchanan parecia bastante sintonizado com esta nova dimensão projetual. Em Traffic in Towns, o engenheiro-urbanista britânico afirmou: "we also conclude in our general review that our task essentially was to explore a problem of design - the design of physical arrangements of buildings and access ways" (BUCHANAN, 1963: 33). No entanto, a questão da dimensão do projeto da rua não apresentava para Buchanan um significado somente atrelado à qualidade urbana:

“(...) to deal with traffic in towns involves a question of design, that is to say of re-design, that is to say of re-designing the physical arrangement of the streets and building in order to cope better with the use of vehicles". (BUCHANAN, 1963: 40)

Além disso, segundo o próprio Colin Buchanan, a lição de Veneza mostrava que um sistema estrutural de circulação e os pedestres não necessariamente precisariam estar em

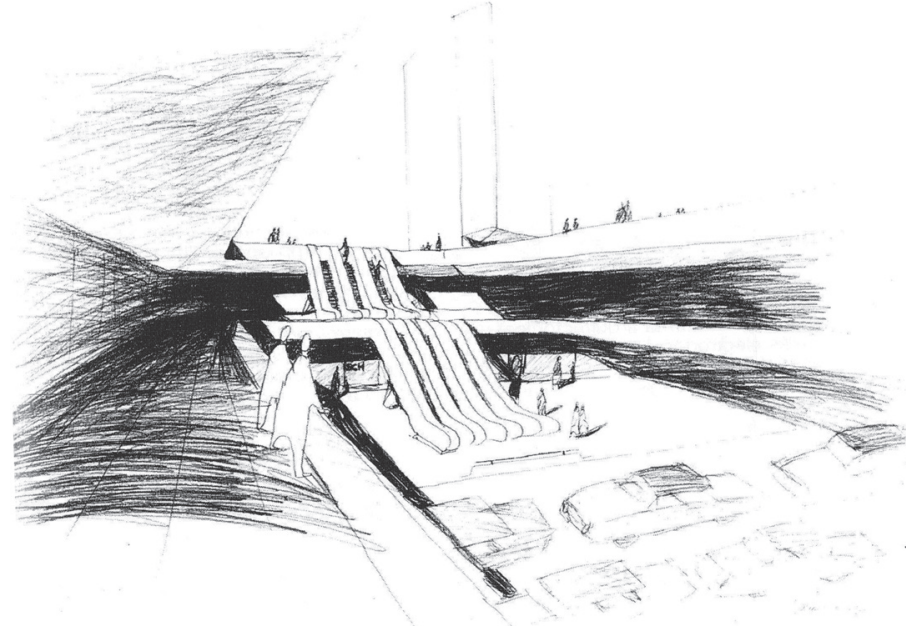

Figura 56: Projeto para o concurso Berlin Hauptstadt, Alison e Peter Smithson - 1957. Perspectiva da relação entre sistema viário e a rede de circulação de pedestres Fonte: VIDOTTO, 1997: 68 
permanente conflito. A experiência italiana evidenciava que uma cidade não se viabilizaria sem o automóvel; no entanto, nada exigia que, no sistema de circulação, pedestres e veículos compartilhassem o mesmo plano urbano (BOAGA, 1977).

O surgimento da rua como um objeto específico do projeto de cidade e a lição de Veneza convergiam para um conceito criado por ocasião do relatório Traffic in Towns. Esta noção seria denominada traffic architecture e envolveria a incorporação do princípio de separação dos conflitos em planos urbanos distintos:

"There is a new and largely unexplored field of design here, but it involves abandoning the idea that urban areas must necessarily consist of buildings set along vehicular streets, with one design for the buildings and another for the streets. This is only a convention" (BUCHANAN, 1963: 46)

Este conceito nada teve de inovador. Vimos como estas idéias se arrastavam desde, pelo menos, uma década antes e eram tributárias da obras de Corbusier. Banhan (1978), comentando o relatório Traffic in Towns e seu o estudo para renovação do centro de Londres, chama-o de típica solução dos anos 1960, sendo também uma espécie de aprovação governamental para as megaestruturas.

A questão que se colocava, no entanto, era o local de aplicação deste conceito. Embora Buchanan não mencionasse, o relatório Traffic in Towns e sua trajetória como consultor indicaram que esta noção seria válida somente para as áreas centrais das cidades e mesmo assim, com grandes volumes de tráfego. Para as áreas periféricas, Buchanan admitia que o "modelo Radburn” havia solucionado a questão satisfatoriamente.

Não por acaso, em Traffic in Towns este conceito foi ensaiado apenas para Londres e não para os outros três estudos de caso. Mesmo assim, a separação em diferentes níveis urbanos, aparece mais incisivamente somente para as alternativas de redesenho parcial e completo da área escolhida no estudo. 
O conceito de traffic architecture parecia ser de fato uma forma de compatibilizar accessibility e environment, tal como definidos no capítulo anterior. $\mathrm{Na}$ alternativa para a completa remodelação da região da University College of London e do Museu Britânico, em Londres, é possível perceber ainda outra distinção, além daquela já mencionada entre áreas centrais e periferia. Neste caso, enquanto a noção de traffic architecture viabilizaria a convivência entre pedestres e veículos nos corredores comerciais, a área do entorno, formada por um generoso sistema viário, não deixaria dúvidas quanto à sua filiação. Tratava-se de uma adaptação "moderada" da engenharia de tráfego norte americana.

De fato, Buchanan deixava claro neste estudo que não estava disposto a sacrificar o acesso dos automóveis à cidade, ainda que fossem necessárias grandes transformações no tecido tradicional da capital britânica. Sua aproximação com as preocupações projetuais na escala da rua tinha validade circunscrita às áreas comerciais.

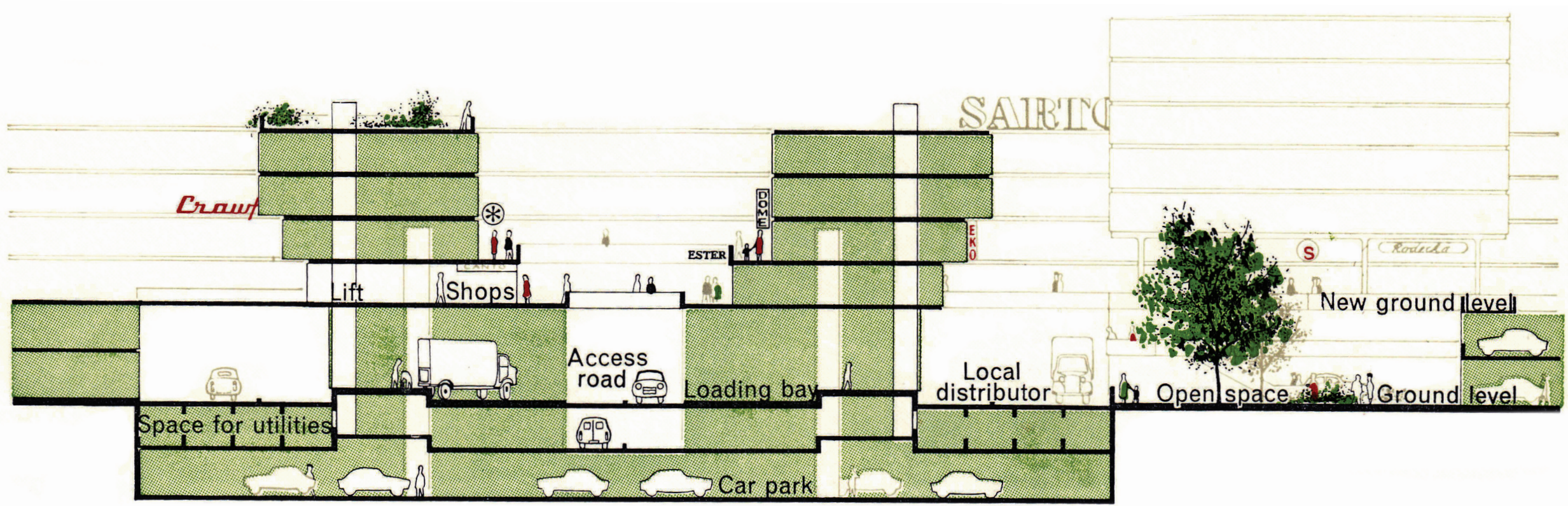

Figura 57: Traffic in Towns: Alternativa para remodelação parcial da região da University College of London e do Museu Britânico (Bloomsbury) - Corte esquemático de um corredor comercial local Fonte: BUCHANAN, 1963: 149 


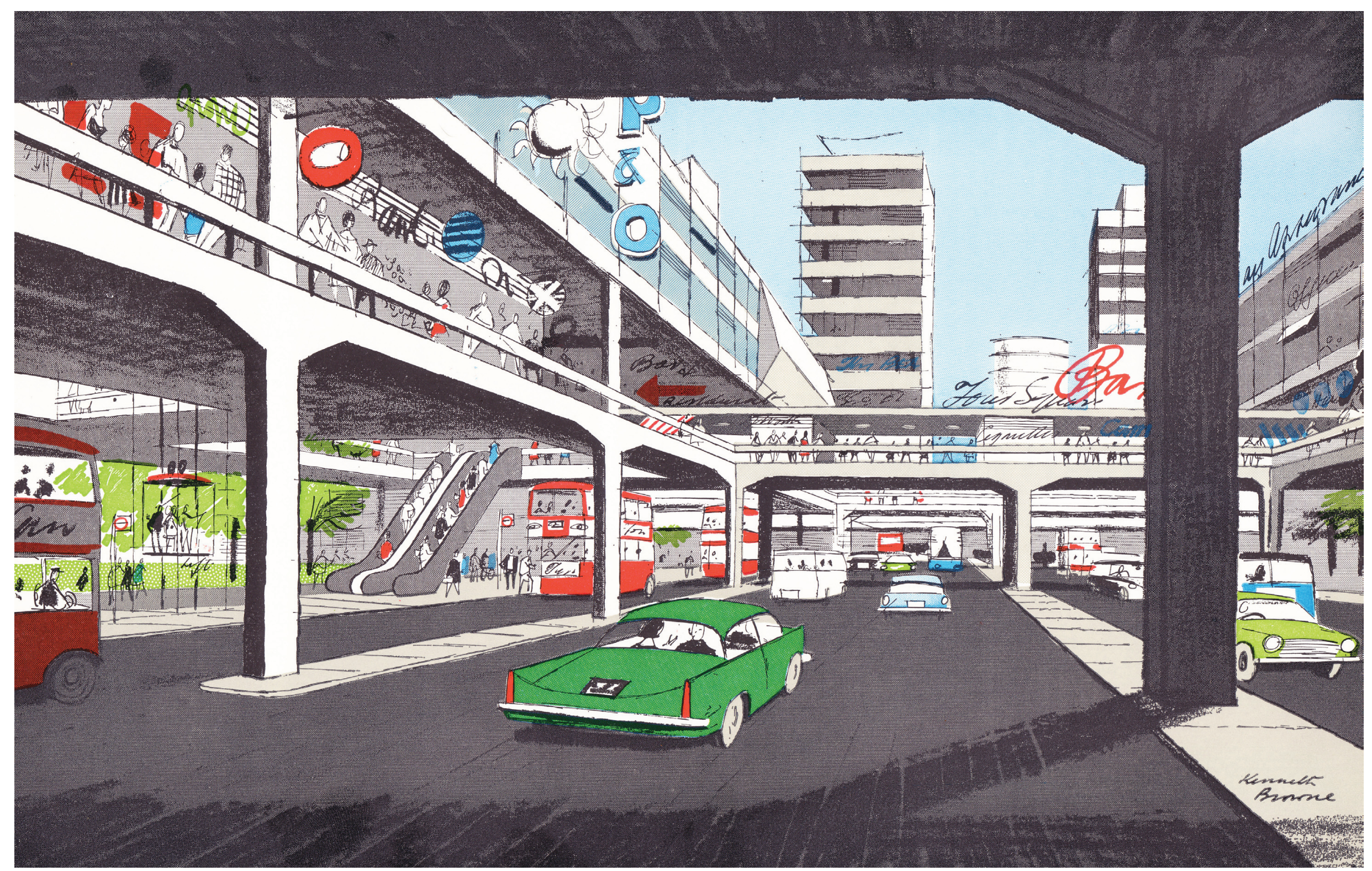

Figura 58: Traffic in Towns: Alternativa para completa remodelação da região da University College of London e do Museu Britânico (Bloomsbury) - corredor comercial Fonte: BUCHANAN, 1963: 143 


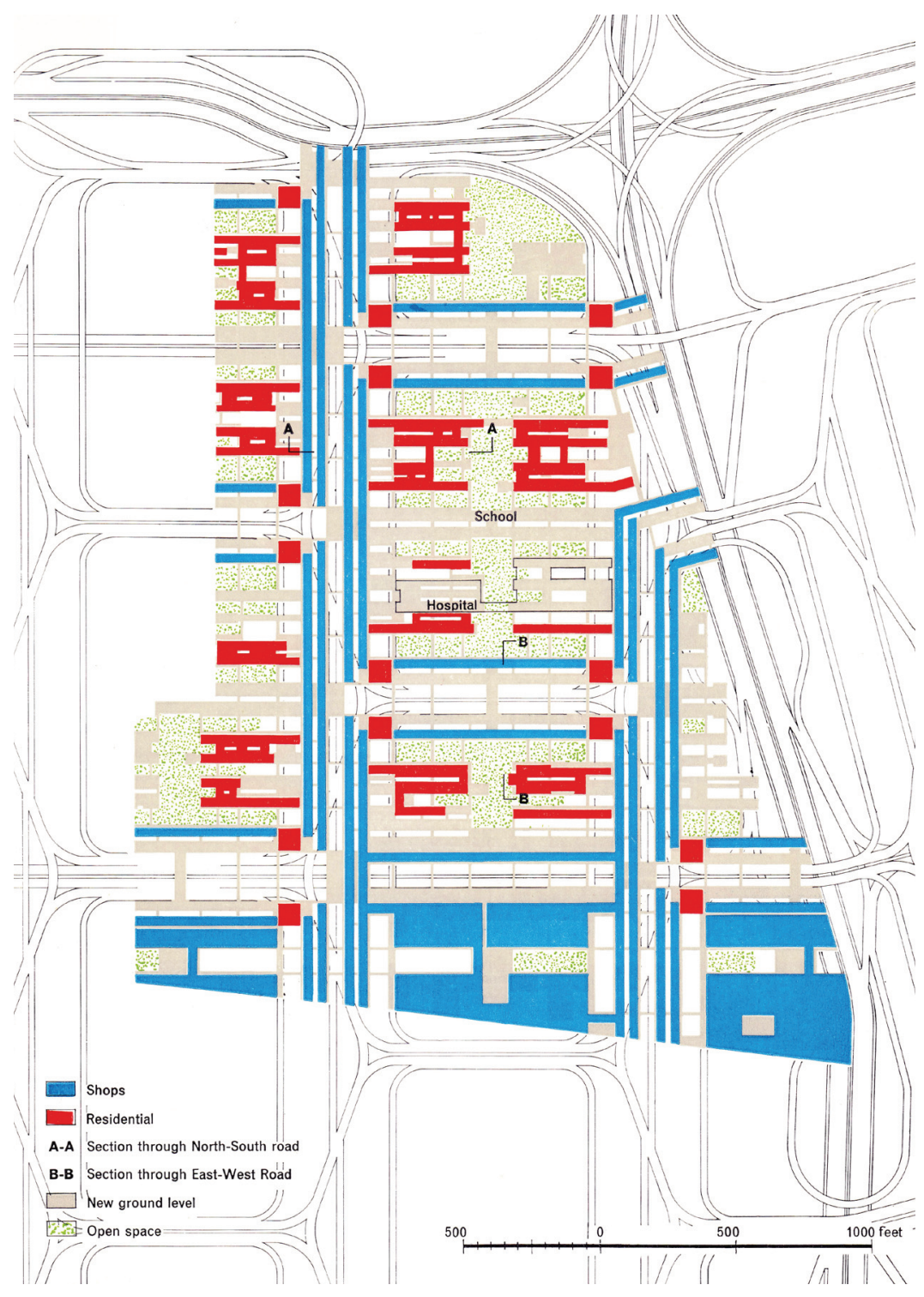

Figura 59: Traffic in Towns: Alternativa para completa remodelação da região da University College of London e do Museu Britânico (Bloomsbury)

Fonte: BUCHANAN, 1963: 139

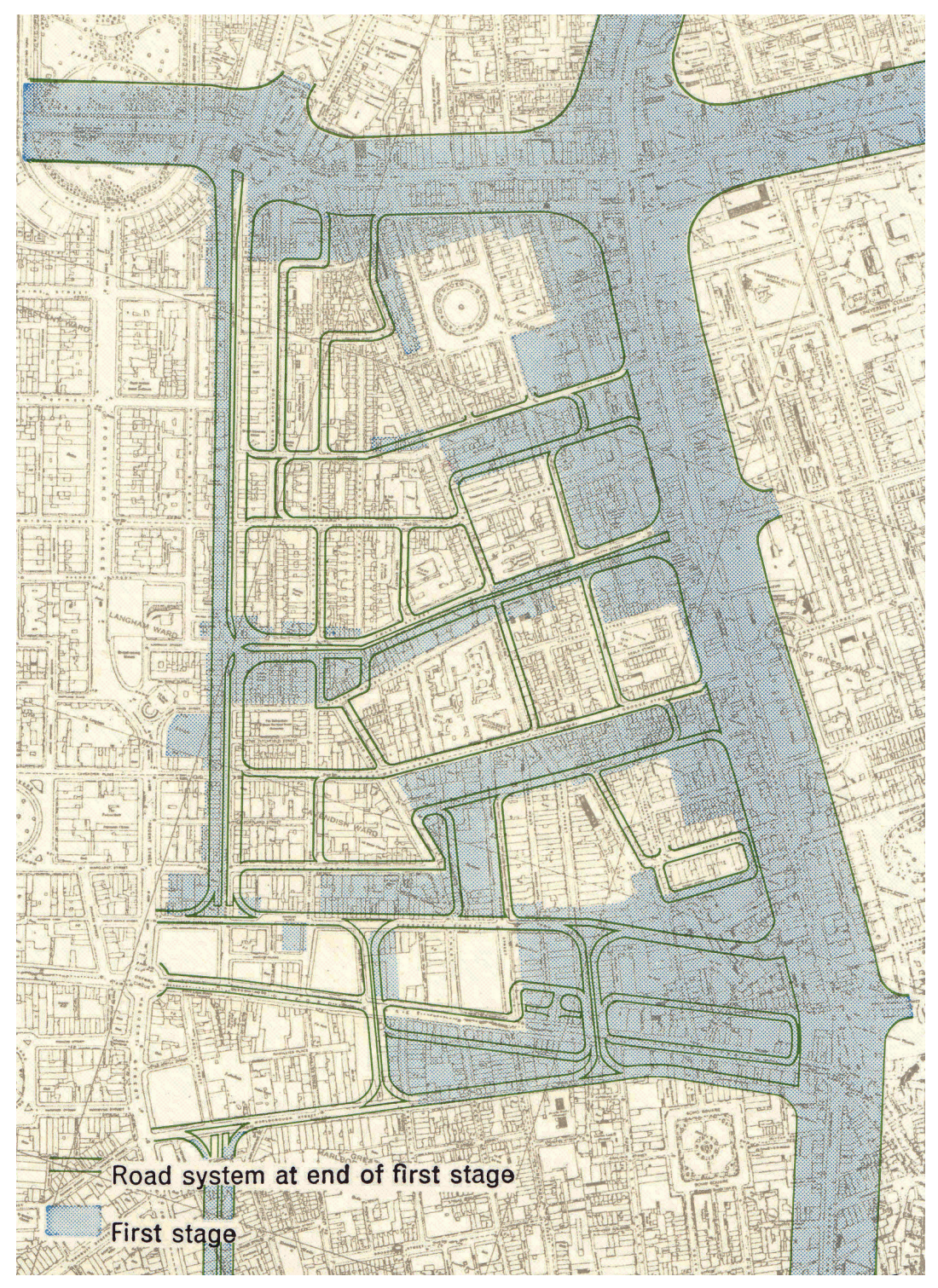

Figura 60: Traffic in Towns: Alternativa para remodelação parcial da região da University College of London e do Museu Britânico (Bloomsbury) - área desapropriada na primeira fase de implantação Fonte: BUCHANAN, 1963: 155 


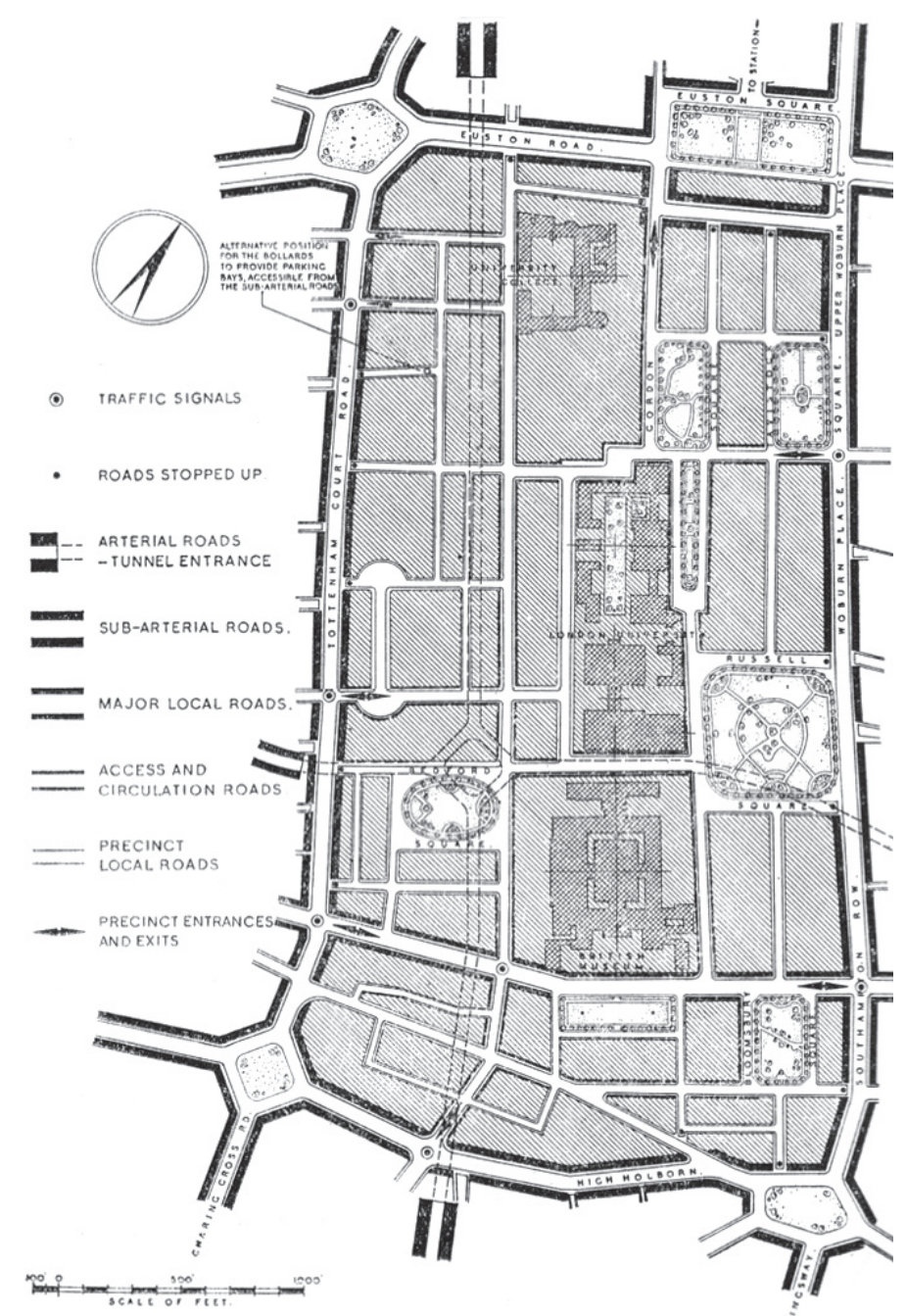

Figura 61: Plano de Londres, P. Abercrombie e J. Forshaw 1943 - Proposta de para University Precinct Fonte: FORSHAW; ABERCROMBIE, 1943: 52
Esta questão fica ainda mais evidente quando se compara o estudo de Buchanan e o Plano para Londres, de Abercrombie e Forshaw. Buchanan curiosamente escolheu uma área situada imediatamente a oeste daquela utilizada como exemplo no Plano para Londres, tendo ambas a Av. Tottenham Court como limite. Enquanto Traffic in Towns optava pela completa remodelação da área e a inserção de um vigoroso sistema viário no entorno, o Plano de Abercrombie e Forshaw resolvia a questão por meio da construção de um túnel, deixando inalterado o tecido urbano existente.

Em outras palavras, enquanto Abercombrie e Forshaw entendiam que a reorganização do sistema viário estrutural seria suficientemente eficaz para a solução dos problemas de tráfego, Colin Buchanan e sua equipe em Traffic in Towns investigavam uma solução para a intervenção completa na área. Neste caso, toda a área seria objeto de uma reformulação urbana, preservando não mais que poucos edifícios considerados relevantes.

Colin Buchanan seria menos incisivo em seus planos e projetos como consultor. No estudo para a cidade de Bath (Reino Unido) a solução proposta seria bem mais generosa com o tecido histórico da área central, prevendo a segregação do sistema viário estrutural em túnel, associado à pedestrianização do nível do solo. No entanto, no entorno do centro, prevalecia a mesma preocupação com o acesso dos automóveis.

Por meio das questões discutidas acima, Colin Buchanan chamou atenção para a dimensão física e ambiental das cidades, daquilo que enquadrou como environment. Se considerava necessário compreender a dinâmica da circulação urbana, como vimos no capítulo anterior, era também relevante investigar as possibilidades de resolução do conflito entre cidade e tráfego na sua dimensão física e, portanto, projetual. As duas dimensões, environment e accessibility encontram no Estudo para South Hampshire uma oportunidade de desenvolvimento conjunto, como veremos na sequência. 

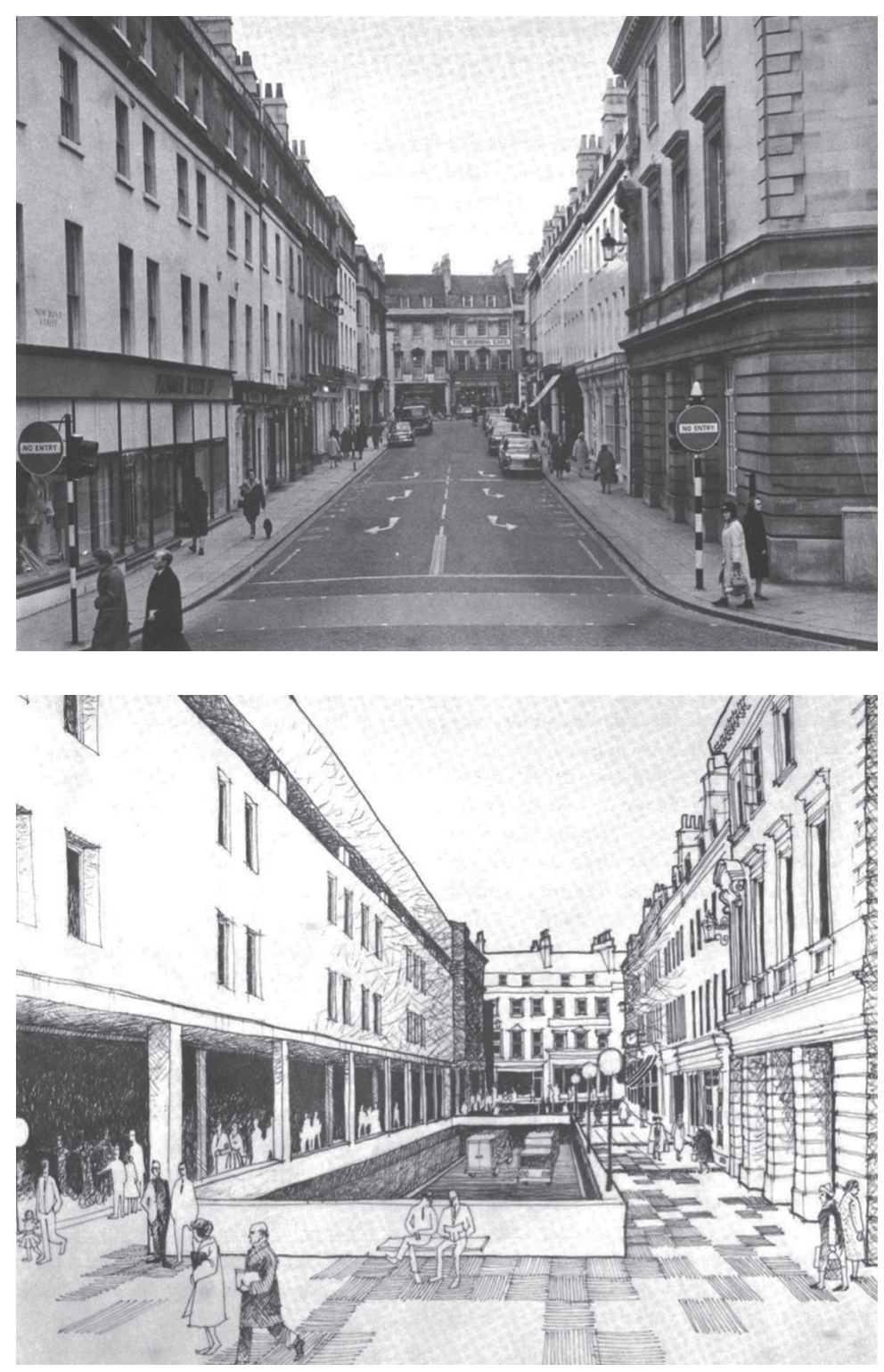

Figura 62: Bath: a planning and transport study, Colin Buchanan \& Partners, 1965

Fonte: COLIN BUCHANAN \& PARTNERS, 1965: figs 57a e 57b
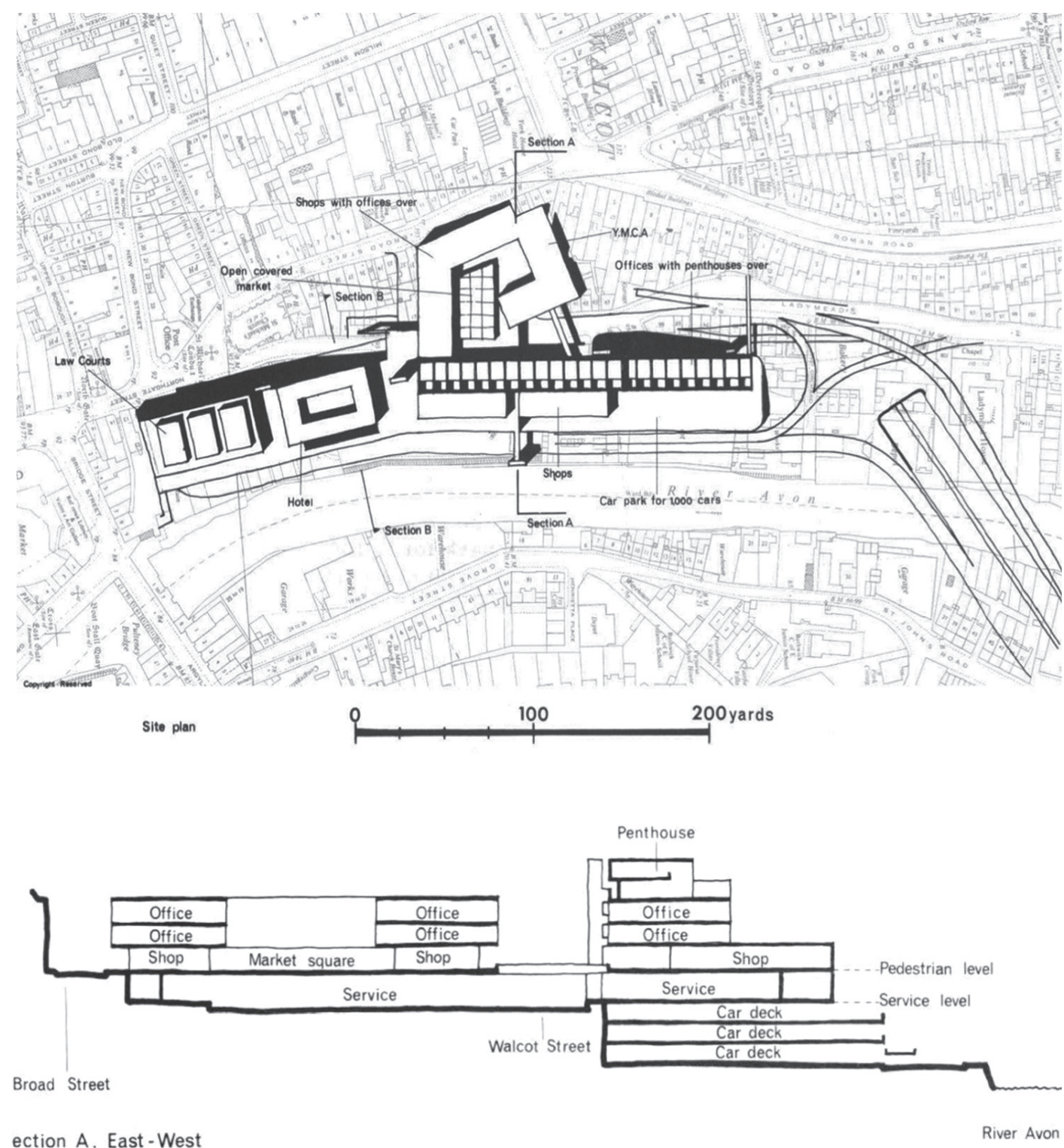

Figura 63: Bath: a planning and transport study, Colin Buchanan \& Partners,1965 - proposta para um edificio multifuncional com amplo espaço para estacionamento Fonte: COLIN BUCHANAN \& PARTNERS, 1965: figs 59 e 60 


\section{capítulo 6}

\section{A estrutura urbana e regional para o tráfego}

O Estudo para South Hampshire (1964-1966) pode ser considerado, em vários aspectos, um projeto síntese da obra de Colin Buchanan. Trata-se de uma oportunidade onde o engenheiro-urbanista investigou não mais os impactos do automóvel nas cidades existentes, como em Traffic in Towns, mas ele mesmo propôs uma nova lógica de estruturação urbana baseada neste modo de transporte.

Nesta proposição, há um posicionamento em relação às tradições urbanísticas que se expressa nas considerações sobre as estruturas urbanas elementares consideradas no estudo. Tal ponderação é realizada, sobretudo, tendo os deslocamentos motorizados como horizonte. As considerações que haviam sido ensaiadas em Traffic in Towns, ganham nesta ocasião uma formatação sistematizada.

A estrutura urbana, proposta por ele nesta ocasião pode ser considerada como uma estrutura que responde a questões colocadas desde 1958 em Mixed Blessing, mas também como o momento em que se expressa uma tensão entre modos públicos e privados. Buchanan ao mesmo tempo em que permanece fiel na sua aposta em relação ao automóvel, parece reconhecer a necessidade de incorporação dos modos públicos em sua prática profissional. Neste contexto, não deixa de chamar atenção um realinhamento, diante de um novo cenário político britânico. 
Ao mesmo tempo, em South Hampshire fica claro o reconhecimento de uma nova escala da urbanização na era do automóvel. A dimensão regional é, neste sentido, uma marca deste estudo.

\section{O Estudo para South Hampshire}

South Hampshire Study pode ser considerado como um dos últimos momentos da vigorosa política de descentralização do crescimento urbano, empreendida pelo governo da Grã Bretanha a partir de meados da década de 1940. O Estudo foi encomendado ao escritório de Colin Buchanan em 1964 pelo Ministério da Habitação e Governo Local, associado aos governos locais de Portsmouth e Sounthampton ${ }^{32}$, tendo sido finalmente concluído em 1966.

Como ação de governo, o South Hampshire Study foi a conseqüência direta da publicação do South East Study em 1964 e esteve de acordo com o principal mote do planejamento regional daquele período: a criação de empregos para o Reino Unido. O South East Study previa a construção de um segundo anel de assentamentos, mais distante da primeira leva de New Towns dos anos anteriores e fora do raio de commuting. O principal objetivo deste estudo era definir uma estratégia geral para o assentamento de aproximadamente 3,5 milhões de novos habitantes na região sudeste da Inglaterra, dentro de um horizonte de 15 anos (1981) (HALL, 2002). ${ }^{33}$

Tratava-se, portanto, da perspectiva de reorganização da população economicamente ati-

32 O Estudo foi contratado pelos Minister of Housing and Local Government, associado ao Hampshire County Council e aos County Borough Councils of Portsmouth e Sounthampton.

33 Muito deste crescimento demográfico era esperado por conta de movimentos migratórios a partir da criação de novos postos de trabalho na região de Londres (cerca de 1,1 milhões de habitantes), mas também fruto do próprio crescimento vegetativo da população (COLIN BUCHANAN \& PARTNERS, 1966: 26). Este esforço não está distante de uma tendência européia de planejamento regional nos anos 1960. Entre os exemplos, destacam-se Paris (1960), Amsterdã (1962), Copenhagen (1961), Estocolmo (1966). Em todas elas emerge a dimensão metropolitana dos assentamentos, graças ao processo de urbanização intenso ocorrido no período pós II Guerra Mundial. A esse respeito ver o Capítulo III, "O desafio da grande dimensão" em Benévolo (2009a). 


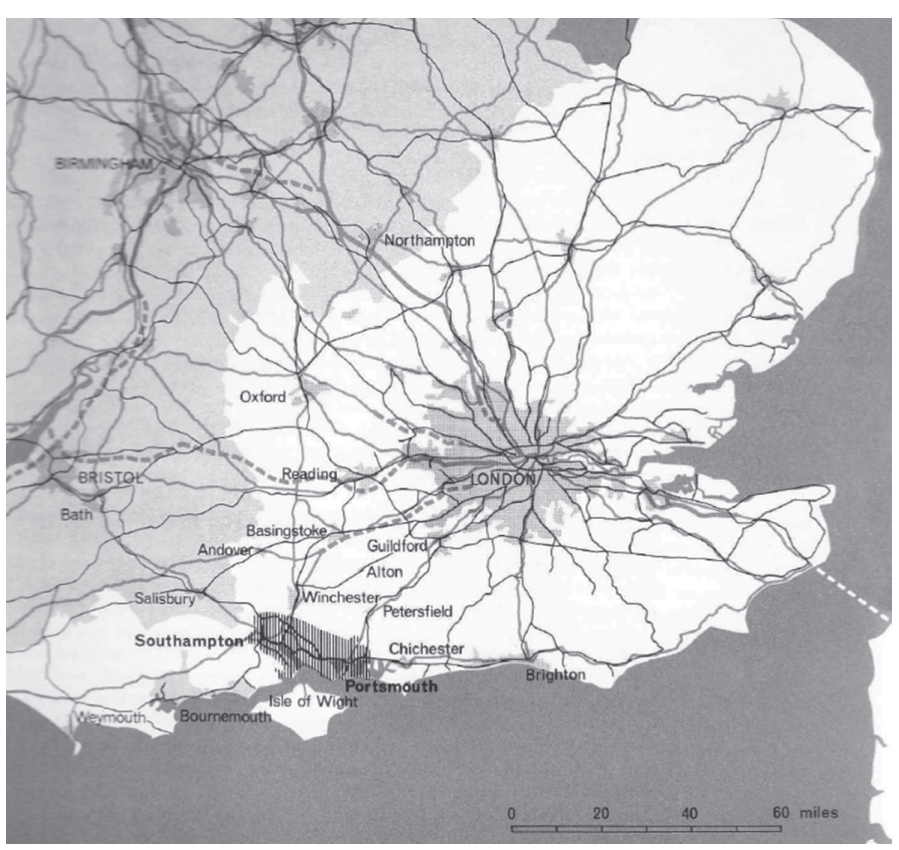

Figura 64: South Hampshire Study, Colin Buchanan\&Partners, 1966 - região Sul da Inglaterra e localização da Área de Estudo de South Hampshire

Fonte: COLIN BUCHANAN \& PARTNERS, 1966, 13 va, que gravitava ao redor da área de Londres, aliviando assim os problemas relacionados à superpopulação da capital. De fato, este esforço governamental pode ser entendido como um desdobramento do plano de Abercrombie e do programa de construção das New Towns levado a cabo a partir dos anos 1940. Mas, neste caso, não só as perspectivas populacionais foram revistas (de 50 mil habitantes nas primeiras New Towns para 250 mil em Milton Keynes) como também as áreas de intervenção foram significativamente ampliadas.

Basicamente, este amplo contingente populacional previsto pelo South East Study deveria ser direcionado para três regiões: Bletchley, Newbury-Hungerford e Southampton Portsmouth, na região de South Hampshire. A incumbência encarregada à Colin Bucha-

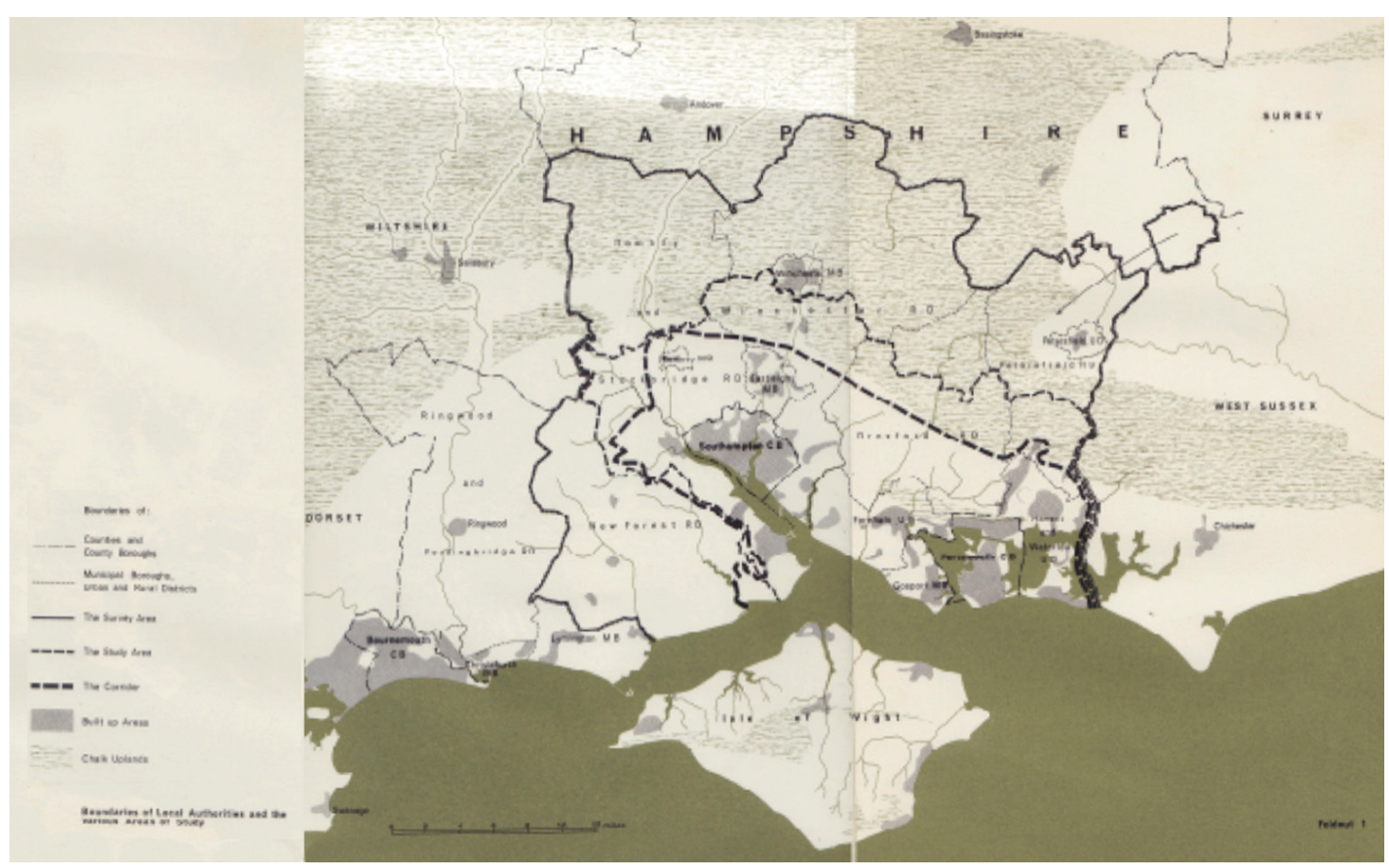

Figura 65: South Hampshire Study, Colin Buchanan\&Partners, 1966 - identificação das áreas de estudo Fonte: COLIN BUCHANAN \& PARTNERS, 1966, fig 1 
nan \& Partners dizia respeito à última das três: as cidades de Southampton e Portsmouth e a região não urbanizada entre ambas. Este recorte - survey area - abrigava uma população de pouco mais de 860 mil habitantes em 1961, dos quais 770 mil pessoas habitavam a área específica do objeto de trabalho - study area. No entanto, as simulações para a área específica de intervenção - the corridor - indicavam a possibilidade de abrigar em torno de 1,7 milhões de habitantes, considerando uma densidade populacional entre 25 e 27 hab/ha.

Neste caso, não se tratava da encomenda de um plano, mas como já é explicitado na sua própria denominação, de um estudo, que deveria investigar formas para a urbanização da extensa área entre as cidades de Portsmouth e Southampton. Já de início, o relatório procura deixar claro que não se trata de um plano diretor:

“(...)But we have been at pains not to produce a master plan, which would have been inconsistent with a feasibility study; in fact, our ideas are presented in diagrammatic form throughout". (COLIN BUCHANAN \& PARTNERS, 1966: 8)

Esta distinção abria a possibilidade de uma investigação de âmbito mais teórico sobre a natureza dos assentamentos urbanos e, como não poderia deixar de ser, da relação entre estes e a mobilidade. De fato, nesta ocasião, Colin Buchanan e sua equipe parecem utilizar os contornos daquilo que poderia ser denominado de um estudo exploratório, buscando parâmetros de planejamento, que, no limite, serviriam para qualquer cidade ou grupo delas. Só então, após o estudo destes princípios, é que o resultado seria aplicado ao caso concreto: a área entre Southampton e Portsmouth.

Em resumo, o resultado deste Estudo pode ser considerado como uma espécie de “tratado sobre assentamentos urbanos na era do automóvel”, que sintetiza as preocupações de Colin Buchanan sobre o futuro das cidades a partir da difusão do uso deste meio de transporte.

Tratava-se, portanto, da formulação de um princípio ordenador de um assentamento urbano em um território e não mais do plano de uma cidade, como as New Towns inglesas: 
We were dealing with an area already considerably urbanized and containing two large cities. We realized it was not a matter of searching for a site for a conventional, if large, "New Town". The area is so complex already and the potential increase of population and activities is so great, that we obviously had to regard the area as a single unit. The task was to discover the principles upon which it could best be developed as one coherent, integrated urban system" (COLIN BUCHANAN \& PARTNERS, 1966: 90)

\section{O conceito de estrutura urbana flexível}

O Estudo para South Hampshire se constituiu como um laboratório para a investigação de diversas questões que seriam incorporadas nas atividades de planejamento conduzidas por Colin Buchanan. Para ele, o planejamento era entendido como um processo, que se iniciava a partir de uma idéia e que se desenrolava em constante processo de revisão. Neste sentido, a flexibilidade era entendida como um atributo fundamental de um plano urbano.

“(...) Planificar es, a nuestro modo de ver, cada vez menos un conjunto de proposiciones precisas en um papel y cada vez más um conjunto de ideas y políticas libremente unidas, bajo constante revisión, dentro de las cuales, tanto ahora como luego, aparezcan los proyetos tan a punto para ser realizados como el juicio humano es capaz de prever. Uma vez ejecutado el proyecto es 'suministrado' al proceso como una influencia para todas las decisiones futuras. Esto es a nuestro entender, 'planificar para a flexibilidad"'. (COLIN BUCHANAN \& PARTNERS, 1970: 21)

O conceito de flexibilidade era o que permitia que as transformações e crescimentos naturais do processo histórico de uma cidade pudessem ser absorvidos sem que o raciocínio ordenador inicial do plano se comprometesse.

Esta noção teve grande repercussão na segunda metade do século XX e, ao que parece, esteve bastante difundida entre os profissionais da época. Tratava-se, no discurso dos 
urbanistas, de uma reação à geração precedente de planos e seu desejo de controle absoluto das transformações das cidades.

"La consideración del problema del cambio y el crescimiento, da lugar a nuevos conceptos. Em nuestros dias se acepta como realidad el hecho de que el disenõ de uma ciudad no és una operación única y de una vez para siempre. Hasta hace poco, los proyectistas consideraban que uma ciudad podía ser proyectada dentro de uns limites fijos, y su crescimiento podría ser previsto através de um control del 'planning"' (LLEWELYNDAVIES, 1970: 38)

Pelo menos para uma parte dos profissionais, a crítica acima tinha endereço certo: Le Corbusier e a corrente modernista dos primeiros CIAMs. Nitschke (1966) propõe a distinção entre duas visões de urbanismo: uma atitude à maneira Renascentista, que se estenderia à Corbusier e que conceberia o plano como fruto da genialidade de um único profissional, responsável pela produção de um "desenho" da cidade; e uma segunda atitude, marcada pela leitura da cidade como processo orgânico, de fluxos em constante transformação.

Outra vertente de difusão da idéia de flexibilidade era o conceito de Master Plan. Conforme Taylor (2008), este era um dos pilares metodológicos do planejamento urbano, no qual se assentou o amplamente divulgado programa de construção de cidades novas britânicas. Podemos admitir que o Master Plan era o instrumento, por excelência, da flexibilidade, que permitia ao processo de projetar a cidade a capacidade de abrigar as alterações inevitáveis ao longo do desenvolvimento urbano. Para isto, eram definidos formalmente somente aqueles elementos essenciais para assegurar a configuração urbana pretendida, entre eles a localização das áreas industriais, centros comerciais, edifícios públicos, escolas, igrejas, hospitais, áreas e lazer e o sistema viário principal. (DUPREÉ, 1987)

O texto justificativo para o plano de Milton Keynes contribui para a melhor compreensão do alcance deste conceito, estendido também ao planejamento de transportes: 
"The proposed transport plan relates to the development of the city over a period about 25 years. The proposals must, therefore, be conceived as a transport strategy rather than a final design. The plan has flexibility to respond to the variations form the proposed land use form, and to change in the transport technology. It also lends itself readily top implementation in stages with development of the city, and to the accommodation of a great diversity of trip orientations". (MILTON KEYNES DEVELOP CO, 1970: 294)

Se as reorientações e variações no crescimento das cidades já eram uma realidade amplamente aceita, outra ordem de "forças" tendia também a alterar o processo "natural" de crescimento, previsto pelos planos. De fato, neste período, também parecia ser real a precaução com as ingerências políticas no processo de planejamento. Dupreé (1987), comentando o processo de construção das cidades novas no Reino Unido, chama atenção para interferências externas de toda ordem: revisões nas metas de população, indisponibilidade das áreas necessárias em tempo, pressões de empresários por áreas diferentes das estabelecidas, revisões dos orçamentos para valores inferiores, etc. O mesmo autor lembra ainda que, por estas razões, os planos tendiam a ser mais indicativos e menos determinantes. Neste sentido, havia que se preservar a dimensão da flexibilidade a todo custo; ou seja, a capacidade de absorver no desenho da cidade, as pressões e ações "externas" que seriam exercidas. O plano para New Town Bracknell, por exemplo, teve sua previsão de população dobrada durante o seu processo de implantação.

Fora das referências britânicas, o trabalho de Constantinos Doxiadis parece também ter repercussão considerável na construção do discurso de Buchanan com relação a este aspecto $^{34}$. O urbanista grego havia se notabilizado pela construção de uma teoria sobre as cidades, que partia do princípio que os assentamentos urbanos possuíam um caráter dinâmico: “(...) the fact that we are now dealing with dynamic settlements has not been fully realized, and most planning of urban settlements is still based on past notions of static cities (...)”.(DOXIADIS, 1968: 249)

34 Conforme Malcolm Buchanan (filho de Colin Buchanan), em depoimento ao autor, Doxiadis e Buchanan se conheciam e mantinham bom relacionamento profissional. 
Embora seu mais famoso texto, o livro "Ekistics: an introduction to the science of human settlements", tenha sido publicado em 1968, suas teses vinham sendo amplamente discutidas por meio do periódico de mesmo nome, do qual Buchanan era um dos muitos practicioners $^{35}$ que colaboraram com artigos. O Estudo para South Hampshire, por exemplo, foi publicado nesta revista no ano seguinte à sua conclusão, em 1967.

Para Doxiadis era particularmente importante o processo de crescimento e deslocamento das áreas centrais da cidade. Buchanan também dedicava grande atenção a este assunto, já que os centros das cidades se constituíam em áreas particularmente problemáticas em relação tráfego de automóveis. Traffic in Towns já evidenciara a grande preocupação de Buchanan com este assunto.

Mas se o conceito de flexibilidade vinha tendo ampla aceitação como forma de se adaptar aos processos de crescimento e transformação das cidades, para Colin Buchanan esta noção parecia admitir ainda outra interpretação. De fato, flexibilidade é também uma característica intrínseca dos modos sobre pneus. Quando comparado a outros modais que atendem grandes distâncias urbanas, o carro e o ônibus se destacam por permitirem grande liberdade de itinerários, comparados aos veículos sobre trilhos: o problema da impossibilidade de trajeto por uma via, seja pelo excesso de veículos ou por qualquer outra causa, pode ser imediatamente solucionado pelo uso de outra. E a simples construção de uma via, não necessariamente pavimentada, abre já a possibilidade de circulação. Particularmente, no caso dos automóveis, esta dimensão é ainda maior: é possibilitado a cada indivíduo escolher seu trajeto praticamente com total liberdade e a cada nova viagem ${ }^{36}$.

Colin Buchanan, na palestra proferida no Instituto de Engenharia de São Paulo em 1966, ressalta esta característica:

35 Segundo o urbanista Jorge Wilhein, em entrevista ao autor, a revista Ekistics era um espaço de difusão teórica e prática do urbanismo nos anos 1960, caracterizada pela divulgação de idéias e planos de urbanistas envolvidos na prática profissional. Wilhein foi assinante deste periódico.

36 É possível assumir que esta seja uma das principais características dos automóveis como meio de transporte e que foi raramente colocada em xeque ao longo dos anos. 
“(...) Naturalmente, muitos equipamentos eletrônicos podem ser desenvolvidos para ajudar os motoristas desses veículos, mas qualquer vinculação de seu movimento a uma via produz de imediato as características do trem com a conseqüente perda de flexibilidade, e qualquer coisa que remova o controle do motorista tende a destruir uma das maiores vantagens do veículo. Se nós temos que continuar a ter o veículo motorizado nós devemos dele obter todos os seus benefícios." (BUCHANAN, 1967: 11)

No entanto, embora a flexibilidade fosse considerada como o principal horizonte de um plano, o próprio Colin Buchanan admitia que não era possível atingi-la plenamente. Neste sentido, era necessário estabelecer diferentes graus de flexibilidade.

É por esta razão que no relatório para South Hampshire Study se empreende um esforço teórico para definir os conceitos de "estrutura" e "sistema". Colin Buchanan e sua equipe atribuem este esforço à “(...) la necessidad de crear uma distinción entre los procesos y actividades que configurasen la vida urbana y el medio ambiente físico, en el cual tienen lugar tales procesos y actividades" (COLIN BUCHANAN \& PARTNERS, 1970: 21). Assim, "estrutura" poderia ser definida como o meio físico construído pelo homem, enquanto "sistema" se tratava da fusão deste meio físico com as atividades e processos que são abrigados pelos primeiros.

Em outras palavras haveria uma "estrutura urbana" e um "sistema urbano". Enquanto o primeiro seria formado pelas ruas, edifícios públicos, habitações, escolas etc; o segundo seria composto pelos processos e atividades humanas que "ocupam" esta estrutura física, configurando a vida urbana. Daí se desdobrariam em "subsistemas", como o "subsistema educacional" ou mesmo como uma espécie de "unidade de planejamento".

Curiosamente, no entanto, o texto de South Hampshire Study não esclarece quais seriam os diferentes patamares de flexibilidade. Embora seja implícito que as "estruturas" têm maior grau de perenidade e, portanto, seriam menos flexíveis, não há qualquer menção a uma possível variação da flexibilidade, internamente às estruturas. Ou seja, no texto, casas, vias ou escolas estariam na mesma condição. 
A idéia de estrutura, sistema e suas possibilidades de crescimento, proposta neste caso, tinha bastante relação com os conceitos desenvolvidos pelo Casal Smithson no final dos anos 1950. Para os arquitetos ingleses, havia ciclos de vida diferentes entre os diversos componentes de uma cidade, desde aqueles curtos até elementos perenes, que conferiam à cidade um grau de identidade.

Günter Nitschke elabora uma justificativa para esta questão:

"One key to establishing a growth-structure is through differentiating objects those whose cycle of change is slow, form those objects existing within cycles of more rapid change and evolution. (NITSCHKE 1966: 172)

Na seqüência, citando Peter Smithson, propõe a concentração do plano nas estruturas perenes:

The structure needs 'fixes' (fixed in the sense that they are changing over a relatively long period) by means of which things changing in shorter cycle can be valued and identified. With a few fixed and clear objects, the transient one-housing, drug stores, shops, and in the shortest cycle, of course, people and their extensions, like clothes, cars, etc - are no longer a menace to sanity and sense of structure, but can uninhibitedly reflect short-term need and justification. If this need of distinction between changing and relatively fixed objects were observed there would be less need for elaborate control over things for which no good case can be made for controlling, and legislative energy could be concentrate on the long-term structure". (NITSCHKE 1966: 172).

É este raciocínio que embasa o Plano para o Centro de Berlim (Concurso para Berlin Hauptstadt), elaborado em 1957 e já comentado neste trabalho. Tratava-se, conforme os arquitetos, de uma estrutura aberta com malhas justapostas (VIDOTTO, 2005: 64), que permitia sua expansão em qualquer direção. E era o sistema viário, neste caso as passarelas de pedestres, que conferiam identidade simbólica ao conjunto: “(...) makes them capable of doing the visual and symbolic unifying job at the same time as they actually make the whole thing work" (NITSCHKE 1966: 173). 


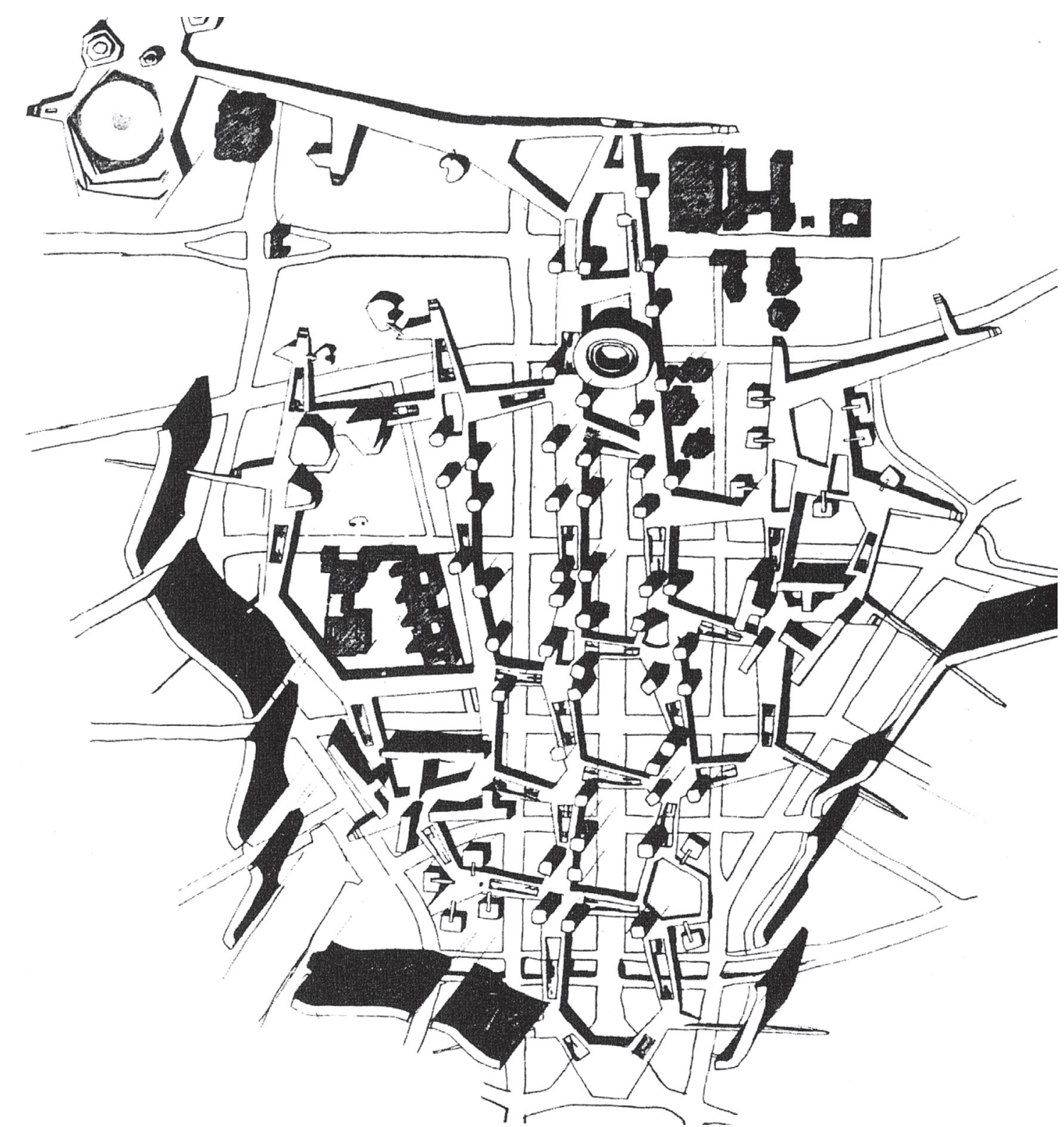

Figura 66: Projeto para o concurso Berlin Hauptstadt, Alison e Peter Smithson - 1957 Fonte: VIDOTTO, 1997: 68 
É a partir da construção deste conceito de "estrutura urbana flexível" que a equipe do South Hampshire Study desenvolveu uma investigação extremamente relevante. Foram admitidas três estruturas urbanas elementares: centrípeta, linear e em trama. Ao denominar como "estruturas básicas" a própria equipe do estudo parece admitir de antemão que se trata de algo com menor grau de flexibilidade. Embora o conceito de estrutura adotado se refira a todo o conjunto edificado, é a configuração das vias que de fato se constituiu em um elemento permanente na visão da equipe.

A partir destas estruturas citadas, uma série de valorações foram colocadas à prova, sobretudo quanto às suas capacidades de absorverem crescimentos e mudanças. Assim, a própria "estrutura básica" deveria conter certo grau de flexibilidade (COLIN BUCHANAN \& PARTNERS, 1970):

- a estrutura deveria possuir máxima liberdade de comunicação e associação através de uma zona

- a estrutura deveria ter condições de operar a partir de implantações parciais, sem que haja comprometimento do funcionamento urbano

- a estrutura deveria prestar-se à transformação e renovação de seus elementos

- elementos internos da estrutura, como o sistema de transportes, não deveriam ser limitadores das necessidades de mudança

- o crescimento da estrutura não deveria engendrar distorções ou deformações.

Os cinco critérios colocados nada mais são que desdobramentos da noção de flexibilidade. Em todos eles o que está em jogo é a capacidade de adaptação da estrutura urbana à novas demandas colocas pelo desenvolvimento urbano.

O relatório para South Hampshire Study, não apresenta uma descrição rigorosa do processo de análise de cada uma das três estruturas adotadas em função dos critérios apresenta- 
dos, mas apenas um parecer final resumido. No entanto, esta questão nos parece muito mais relevante no resultado final do Estudo do que nos indica o Relatório e merece uma investigação um pouco mais aprofundada. Entendemos que é a partir das considerações sobre estas três propostas que Buchanan constrói sua proposta de uma estrutura urbana mais adequada para a cidade na era do automóvel.

\section{A discussão sobre a estrutura urbana}

\section{A estrutura urbana centrípeta}

A estrutura urbana centrípeta (ou rádio-concêntrica) foi abolida como uma das opções do Relatório, com o argumento de que se tratava de uma estrutura rígida, onde qualquer crescimento desigual teria sérios desdobramentos na configuração da área central. Além disso, apresentaria pouca flexibilidade dos sistemas de transportes em relação à variação da demanda.

Este tipo de estrutura já havia sido amplamente debatido por Colin Buchanan por ocasião do livro Mixed Blessing e mesmo do relatório Traffic in Towns, como já comentado neste trabalho. Embora sem a definição da questão como "estrutura", em ambas as ocasiões Buchanan havia discutido sobre as soluções baseadas nas ring roads, particularmente discordando das propostas de Patrick Abercrombie e Alker Tripp para Londres.

A estrutura centrípeta em South Hampshire Study apresenta um centro principal e uma série de subcentros, formados a partir das vias radiais, sendo fatalmente uma decorrência do desenvolvimento da cidade. Associados a estes subcentros, vias perimetrais fariam a dispersão do tráfego que não teria a área central como destino.

No entanto, a rápida descrição da avaliação da estrutura parece não revelar algumas razões pelas quais ela foi descartada. Uma observação da figura escolhida por Buchanan e sua equipe como representativa da estrutura centrípeta parece indicar muito mais que 
as razões apontadas em South Hampshire Study. A semelhança com as propostas contidas em "Cidades Jardins de Amanhã" (HOWARD, 1902) são bastante reveladoras. A teoria de Howard previa uma rede de pequenas cidades associadas a uma cidade principal, numa configuração formal muito parecida com o diagrama da estrutura centrípeta do relatório. Em ambas, a escala regional é que ditava o caráter dos assentamentos.

De fato, passando por Abercrombie e Keeble e finalmente chegando na sua origem Howardiana, Buchanan parecia romper com a forte tradição de Cidade Jardim amplamente presente no urbanismo britânico. Aqui, ao que parece, os argumentos para esta atitude incisiva e, de certa maneira corajosa, encontram-se no mau desempenho deste tipo de estrutura, considerando os transportes sobre pneus.

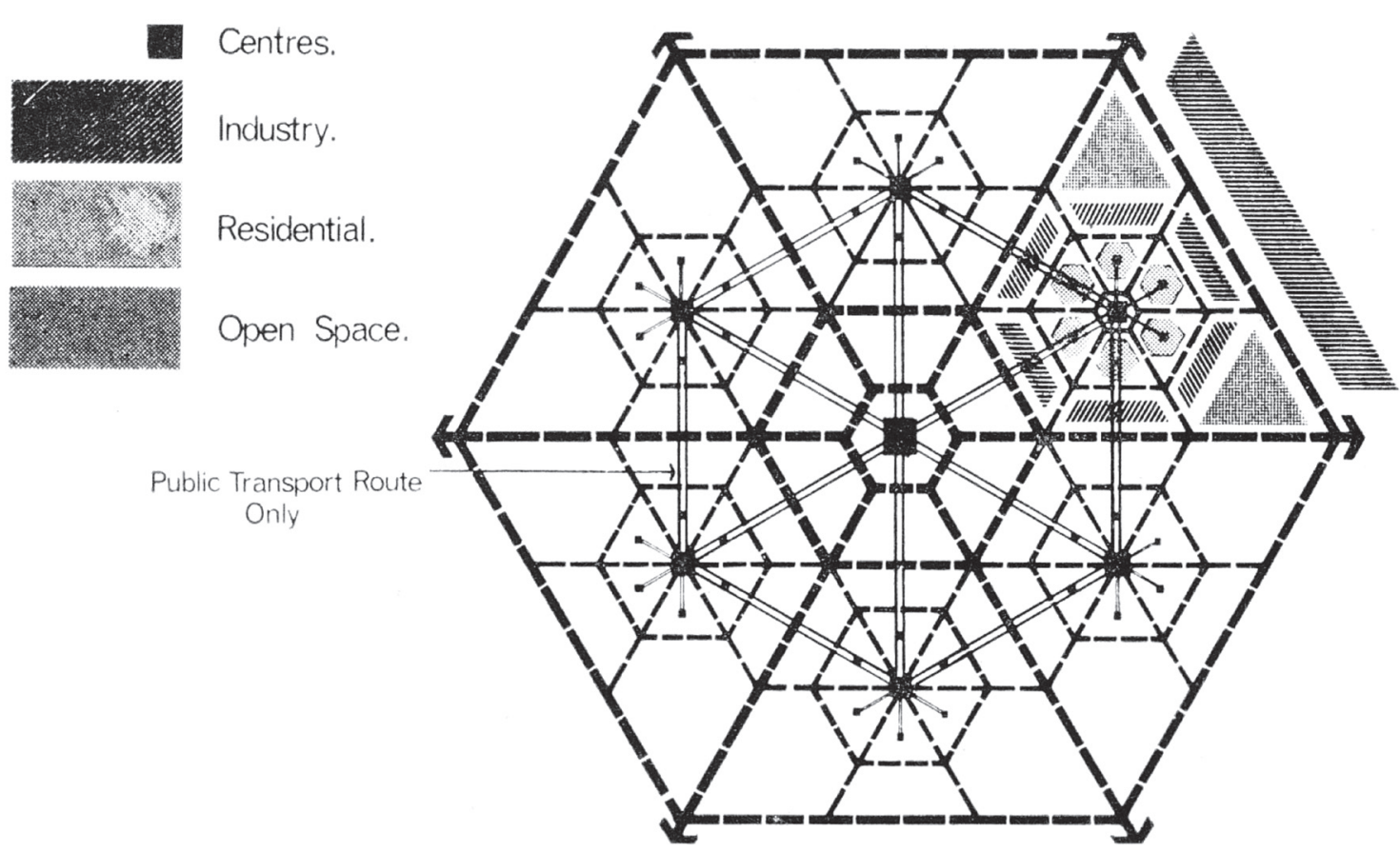

Figura 67: South Hampshire Study, Colin Buchanan\&Partners, 1966 - estrutura centrípeta Fonte: COLIN BUCHANAN \& PARTNERS, 1970: 23

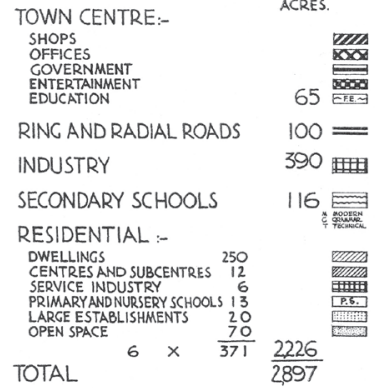

\section{$\stackrel{5.000 \mathrm{FET}}{\square-000}$ \\ RADIUS 1.2 MILES (6.336) AREA 4:54 SQ. MLLES POPULATION 60,000
DENSITY 20.72 P.P.}

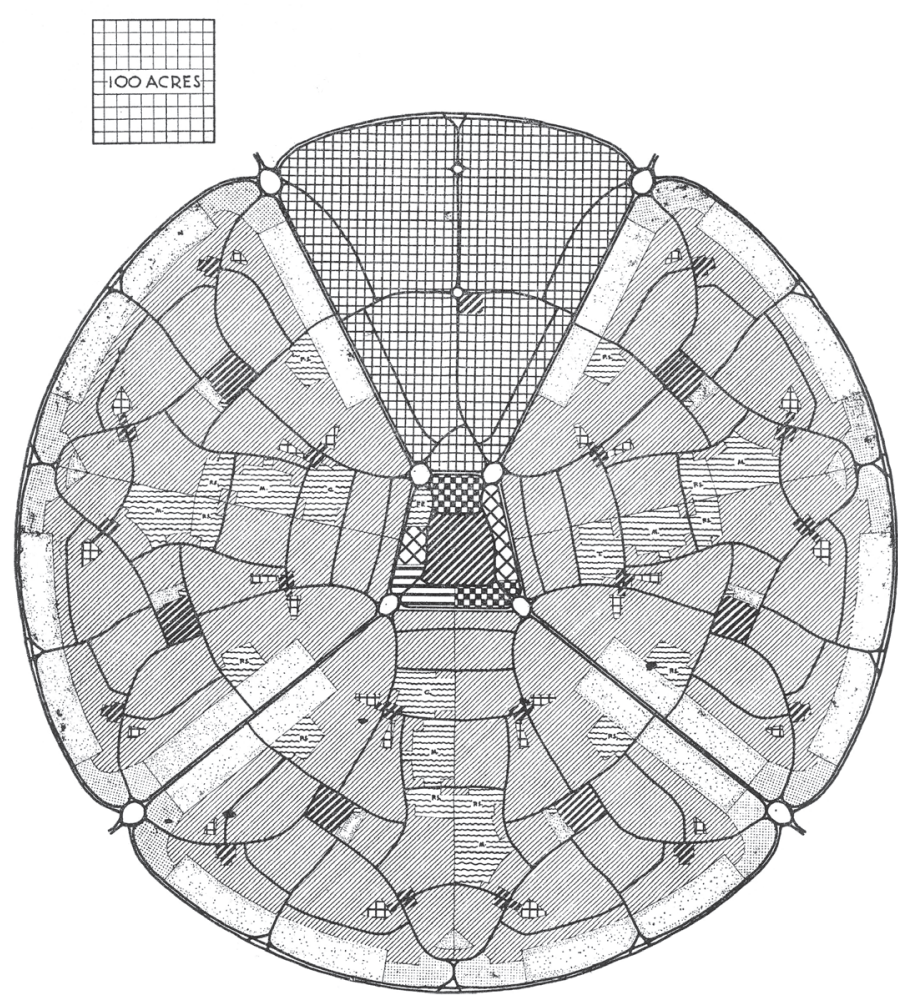

Figura 68: Cidade nova teórica Fonte: KEEBLE, 1959: 84 


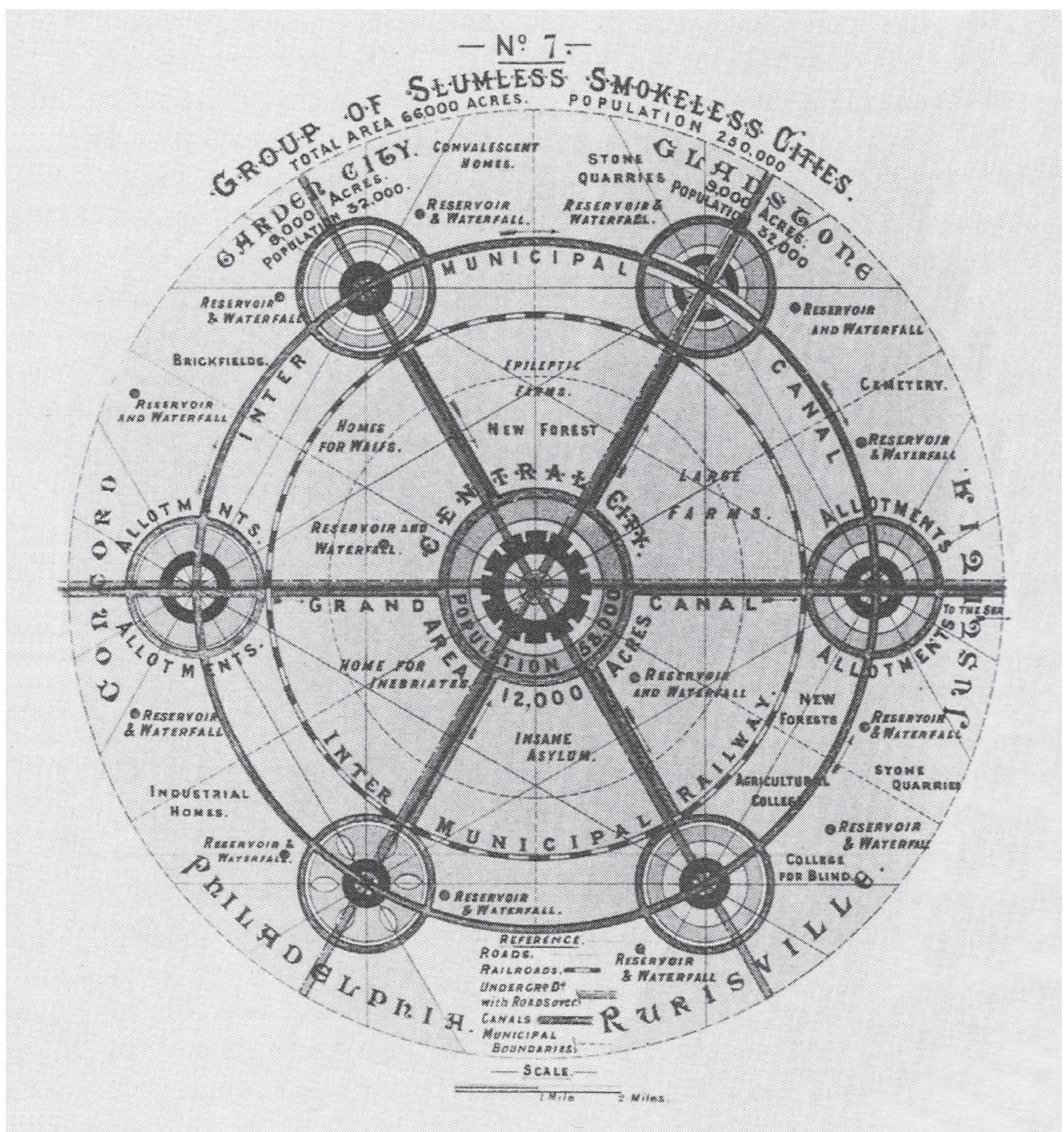

Figura 69: Rede de Cidades-Jardins proposta por Howard na $1^{\circ}$ Edição do seu livro Fonte: HALL, 2002: 34 
Thomson (1977: 162-165) faz uma interessante análise do comportamento deste tipo de estrutura do ponto de vista dos transportes. Para ele, os exemplos que melhor caracterizam o arquétipo "Strong-Centre Strategy", seriam aquelas capitais que observaram a emergência de áreas centrais com forte poder de atração até o século XIX, portanto antes da disseminação do uso dos automóveis.

Nestes casos, “(...) the volumes of employment and other activity were already so large that private transport could not possibly serve the needs of more than a small percentage of travelers to the city centre" (THOMSON, 1977: 162). De fato, as vias radiais não teriam condição prática de dar conta do volume de tráfego exigido em função da quantidade de empregos abrigados por estes centros urbanos.

Em uma rápida contabilização dos valores envolvidos, o mesmo autor ressalta que, adotando a situação de um centro hipotético com 500 mil empregos (abaixo de valores observados nos anos 1970 nas cidades de Londres e Tokyo, por exemplo) e a plena motorização dos trabalhadores, tal suposição geraria um volume de tráfego da ordem de 400 mil veículos na hora pico. Assim, os resultados da previsão de espaço viário apontariam a necessidade de 25 vias expressas de oito faixas cada uma. Isto sem contabilizar o espaço necessário para o estacionamento destes veículos (THOMSON, 1977).

Esta rápida simulação explica a importância de sistemas radiais sobre trilhos nas principais cidades do mundo, caracterizadas por áreas centrais com forte vitalidade. Mas também revela, mais uma vez, a opção de Colin Buchanan pelos modos sobre pneus e, particularmente, o automóvel. Ao descartar a estrutura rádio-concêntrica ou centrípeta, Buchanan enfraquece a eventual importância dos sistemas sobre trilhos na proposta que vinha sendo desenvolvida e concentra todo seu esforço teórico nos modos sobre pneus.

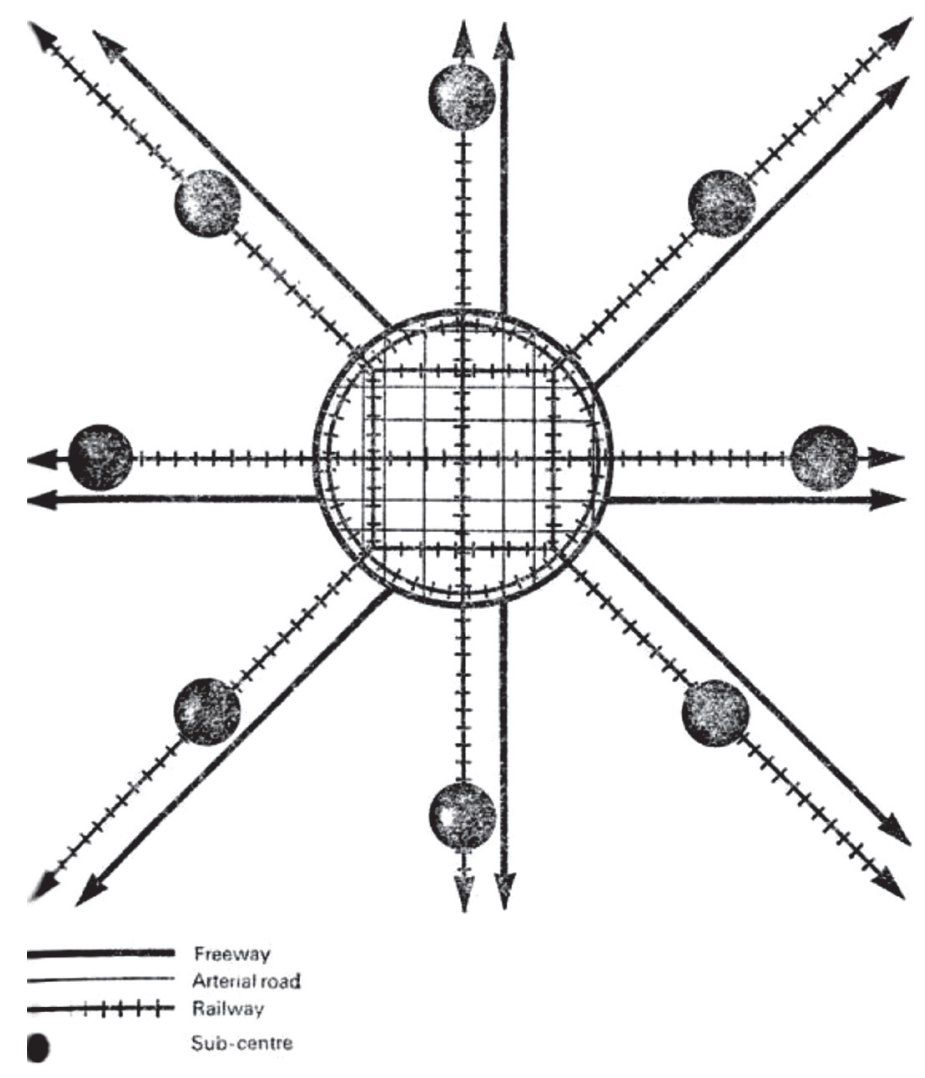

Figura 70: Arquétipo Strong City Centre, proposto por Thomson Fonte: THOMSON, 1977: 163 


\section{A estrutura urbana linear}

Já quanto à estrutura linear, a equipe avaliava que o processo de crescimento urbano e o desenvolvimento de vias associadas ao eixo gerador urbano acabariam por comprometer o caráter único do eixo principal, gerando conseqüências para os sistemas de transportes. $\mathrm{Na}$ verdade, este problema se resolveria "en una trama lineal canalizada que, para su identificación, la llamaremos "trama direccional”" (COLIN BUCHANAN \& PARTNERS, 1970: 22).

Colin Buchanan e sua equipe apontam desde já sua preferência: a trama direcional, aparentemente um simples desdobramento da estrutura linear. Esta apresentaria a desejável flexibilidade, dado que "teoricamente sería ampliamente adaptable al crescimiento en las presentes condiciones del terreno” (COLIN BUCHANAN \& PARTNERS, 1970: 23). Além disso, os transportes público e privado sobre pneus poderiam conferir uma direção predominante ao crescimento urbano.

O grande entusiasmo da equipe em relação às potencialidades a partir da estrutura linear pode ser explicado pelo fato de que se trata daquela que apresenta melhor desempenho em relação aos transportes e à infra-estrutura, de maneira geral. Ela própria é baseada em um eixo contínuo de transportes ou em um feixe paralelo deles (LYNCH, 1981). Para os planejadores urbanos as vias de uma cidade linear são como a espinha dorsal, cujo objetivo é obter a mais eficiente e mais orgânica relação entre as vias e as funções urbanas, numa tentativa de preservar as pessoas dos problemas ambientais relacionados ao tráfego e ao mesmo tempo garantir grande acessibilidade (COLLINS, 1966)

Talvez por estes motivos - o de sua eficiência do ponto de vista dos transportes - a cidade linear tenha sido discutida só muito recentemente, a partir do final do século XIX, com Arturo Soria y Mata em Madrid, quando a questão dos transportes motorizados na cidade passou a assumir maior importância. Ele e um dos seus seguidores, o também espanhol Gonzalez del Castillo, desenvolveram estudos muito semelhantes em que a nova cidade linear seria uma solução para o crescimento de cidades existentes. 
Assim, se por um lado, sua eficiência do que diz respeito aos transportes era considerada um grande valor, por outro é também esta aposta nas possibilidades de expansão das cidades lineares que parece estar por trás da avaliação positiva da equipe do Estudo para South Hampshire.

Conforme Collins (1966), atrás de todo plano para cidade linear ao longo do século XX está a convicção de que o enfrentamento do problema da grande escala no futuro só poderia ser tratado por um esquema que permitisse uma infinita e integrada expansão, simultaneamente tanto do centro como das periferias. De fato, as experiências teóricas em relação a este tipo de estrutura urbana, sugerem a questão da emergência da expansão urbana numa nova dimensão: a escala regional; muito adequada, aliás, aos objetivos do Estudo para South Hampshire.

A este respeito interessa muito a comparação de dois planos e uma proposta teórica

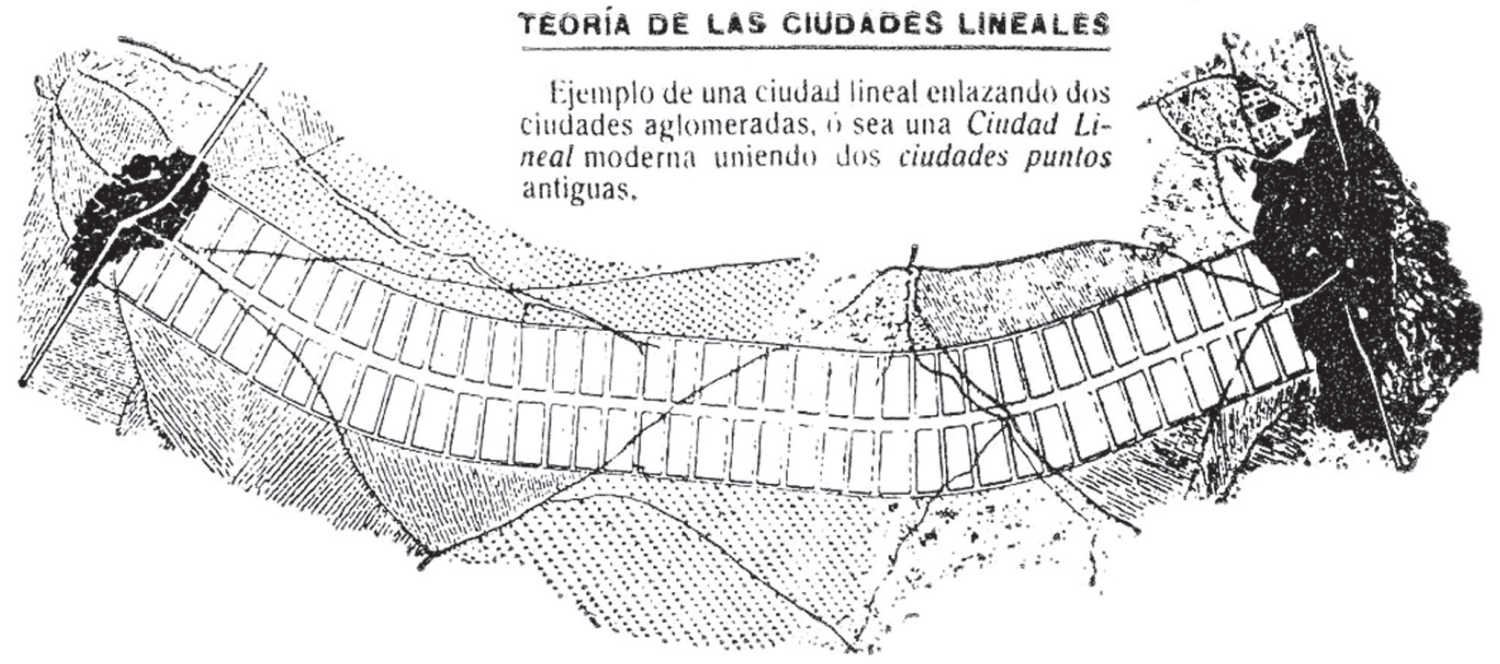

Figura 71: Proposta para Cidade Linear elaborada por Arturo Soria y Mata Fonte: COLLINS, 1966: 204

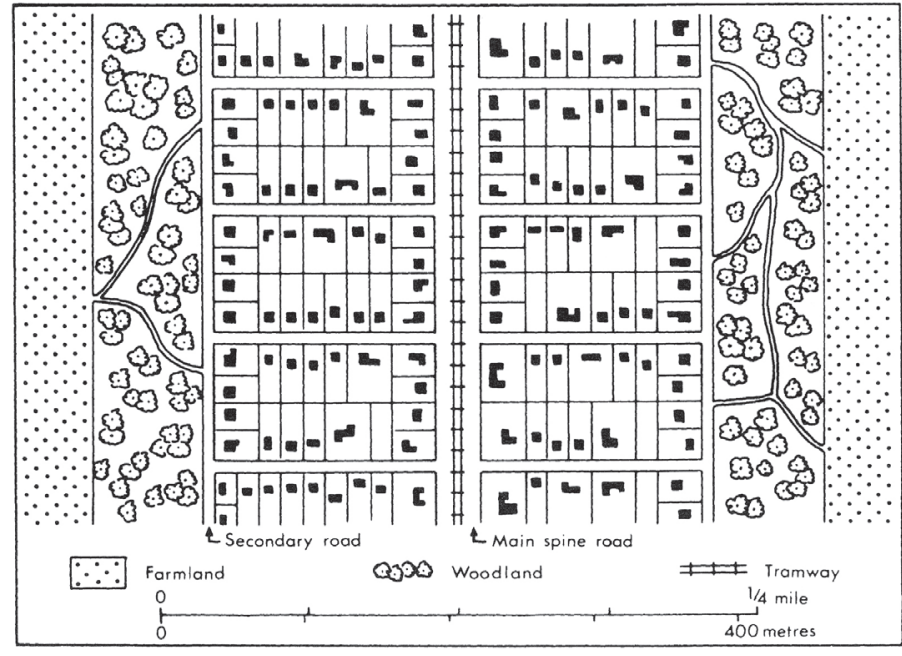

Figura 72: Detalhe da Cidade Linear de Arturo Soria y Mata Fonte: HALL, 2002: 48 


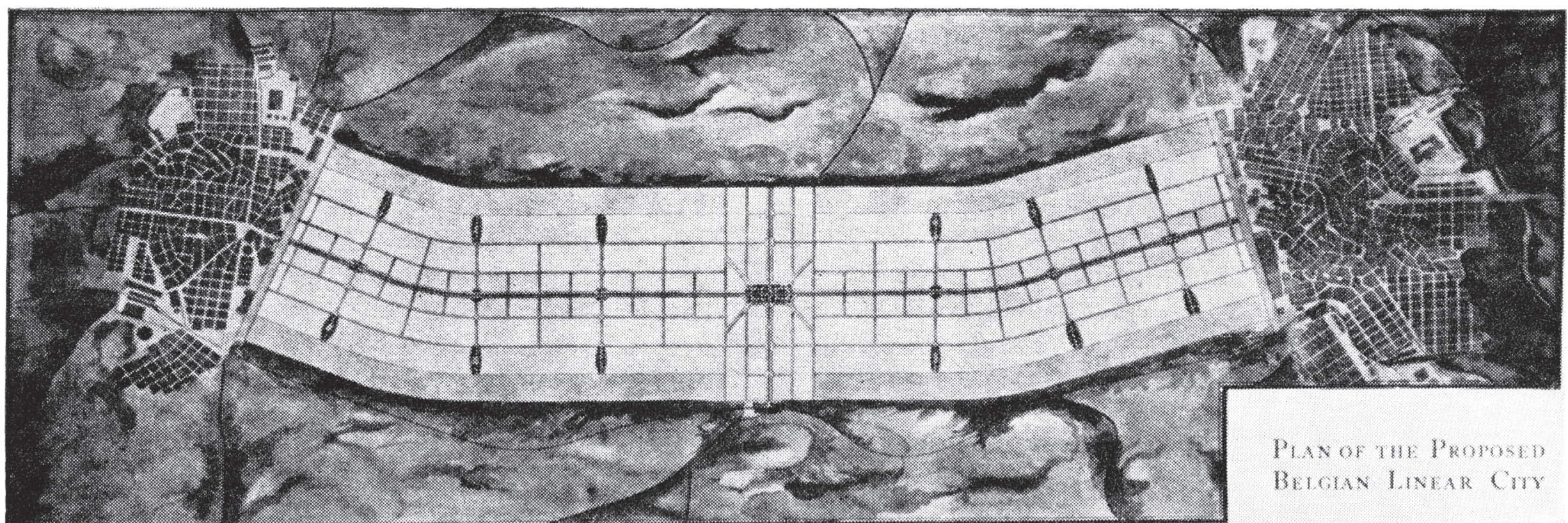

Figura 73: Cidade linear típica na Bélgica, elaborada por Del Castillo em 1919 Fonte: COLLINS, 1966: 2006

elaborados para Londres na primeira metade do século XX. Enquanto os planos de Abercrobie (1943) e Abercrobie/Forshaw (1944), já discutidos anteriormente, pensavam a dimensão regional a partir de uma lógica concêntrica; o estudo teórico apresentado pela equipe Modern Architecture Research Group (MARS - 1938-42) admitia a completa transformação da cidade em uma estrutura linear ramificada, na qual as habitações estariam associadas a vias secundárias vinculadas a um grande eixo de transportes ${ }^{37}$.

Se o Plano de Abercrombie propunha uma corajosa desconcentração populacional a partir da construção de novas cidades, além da "proteção" da cidade pela configuração

37 Devo parte dos comentários relativos ao estudo teórico do Grupo MARS ao Prof. Renato Anelli. 
de cinturão verde, a outra proposta não indicava tais limites demográficos. A forma de expansão, ao que parece, em vez de se realizar pelo crescimento das ramificações, se daria pela extensão do eixo principal. Assim, enquanto a escala regional está na construção de novos assentamentos no primeiro caso, no segundo é a extensão quase ilimitada do eixo de transportes que confere esta característica.

A questão do enfrentamento da escala regional por meio de estruturas lineares não esteve ausente do debate dos CIAM's. No seu livro "Os três estabelecimentos humanos", Le Corbusier sintetizou as discussões ocorridas durante uma das reuniões da Assembléia dos Construtores por uma Renovação Arquitetônica (ASCORAL) em 1942. Neste caso, a estrutura linear foi proposta como uma forma de implantação mais racional das

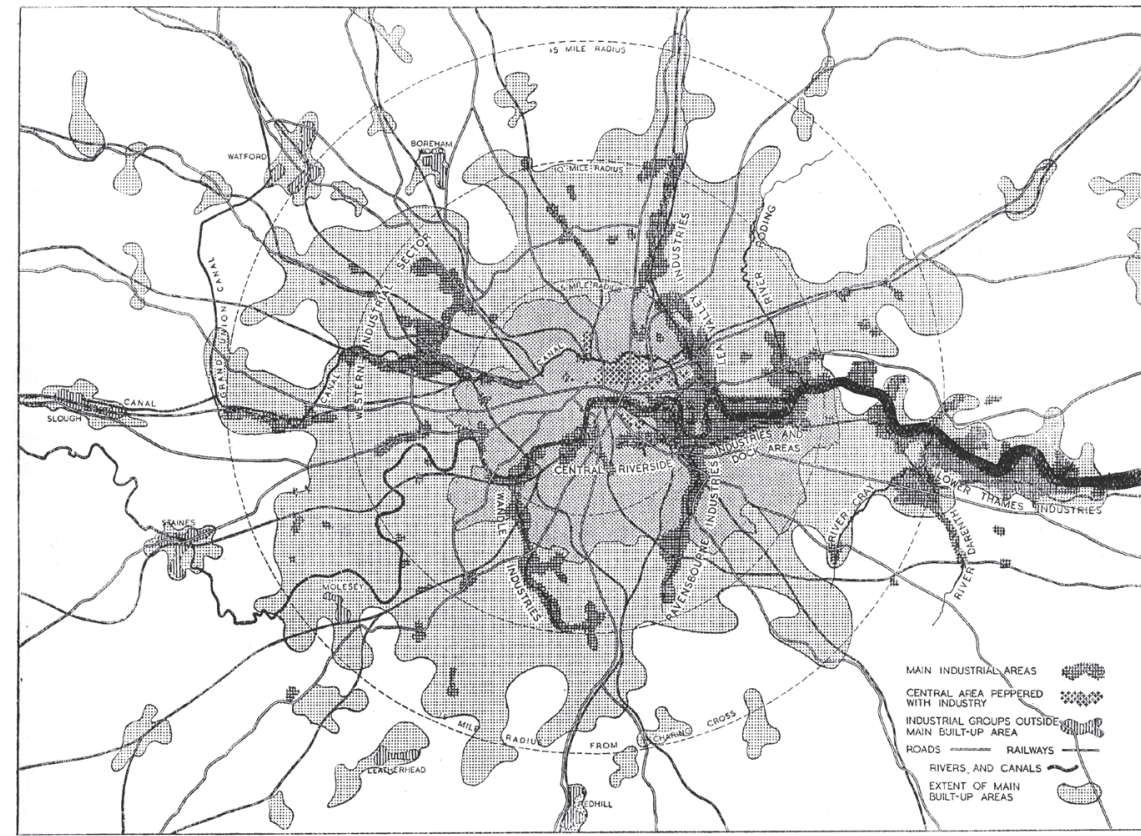

Figura 74: Plano para Londres - Patrick Abercrombie, 1943 Fonte: ABERCROMBIE, 1943: 91

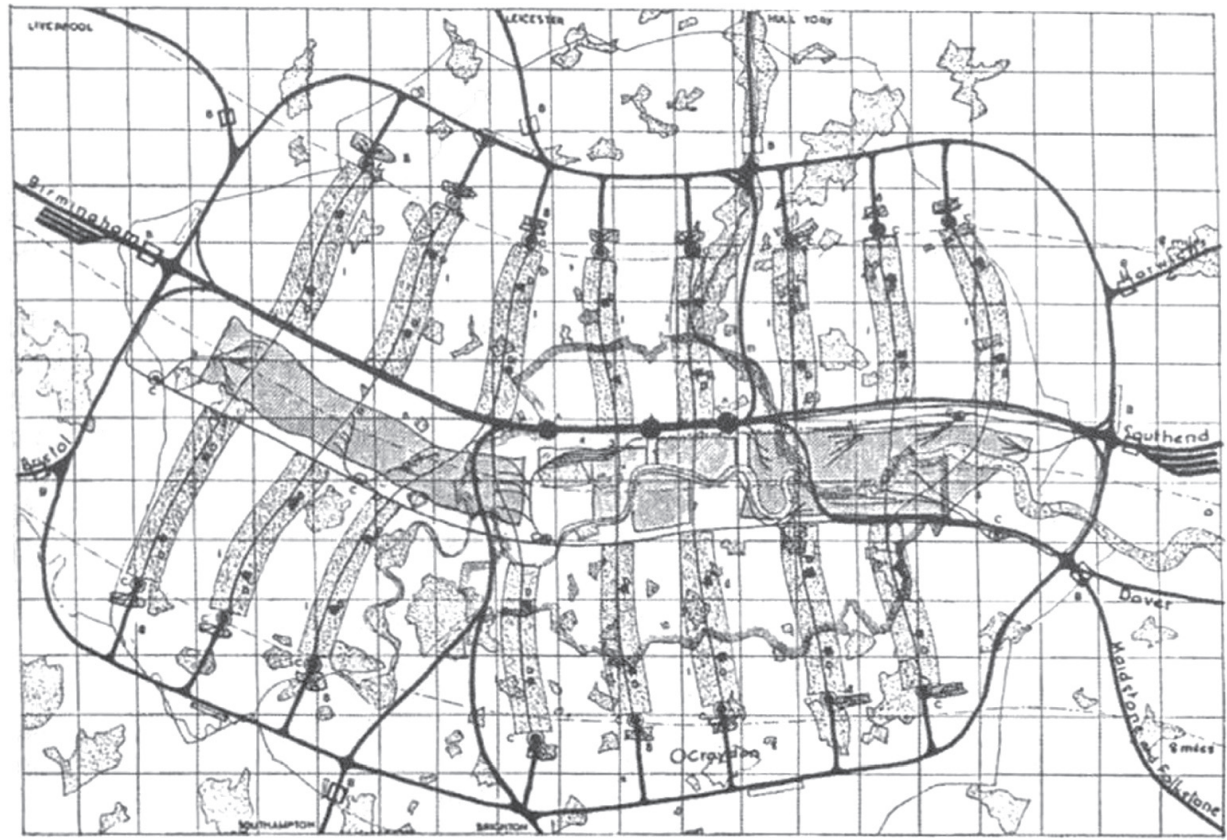

Figura 75: Plano para Londres - Grupo MARS (1938-42) Fonte: COLLINS, 1966 :215 
unidades produtivas no território, baseadas nas estruturas de transportes:

"Diante da falência das cidades industriais radio-concêntricas, nesta diligência que consiste em descobrir se pode ser proposta, em substituição, uma forma biológica de cidade industrial favorável, o fato de reconhecer, de designar e conservar lugares por onde passam as matérias-primas e os produtos fabricados é o primeiro ato produtivo." (LE CORBUSIER, 1979: 126)

As idéias desenvolvidas por Corbusier nesta ocasião parecem ter relação direta à proposta inglesa. Neste sentido, no estudo elaborado pelo Grupo MARS, o eixo de transportes estaria associado em grande parte às implantações industriais, conforme é possível observar no mapa do Plano de Abercrombie (1943).

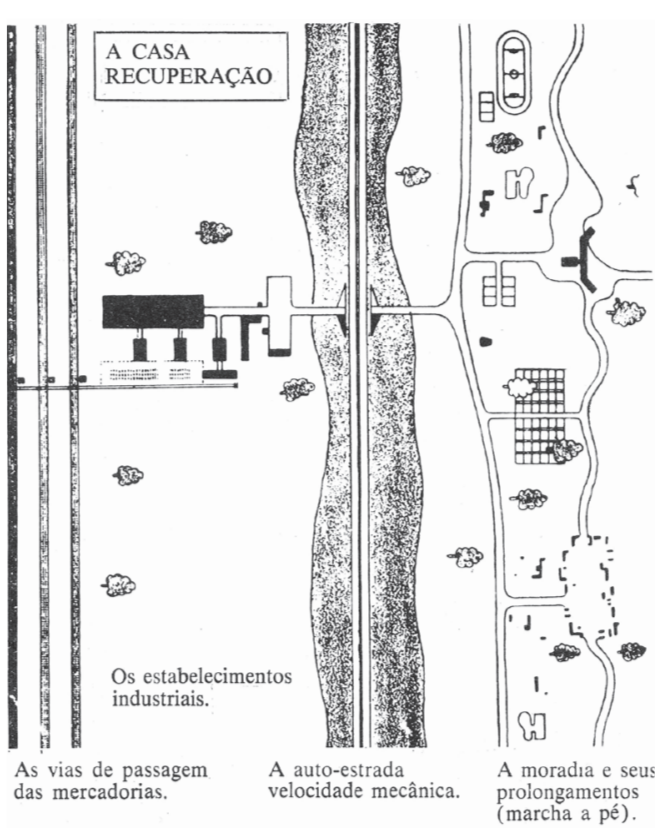

Figura 76: Arranjo das diferentes funções na escala regional linear

Fonte: LE CORBUSIER, 1979: 147

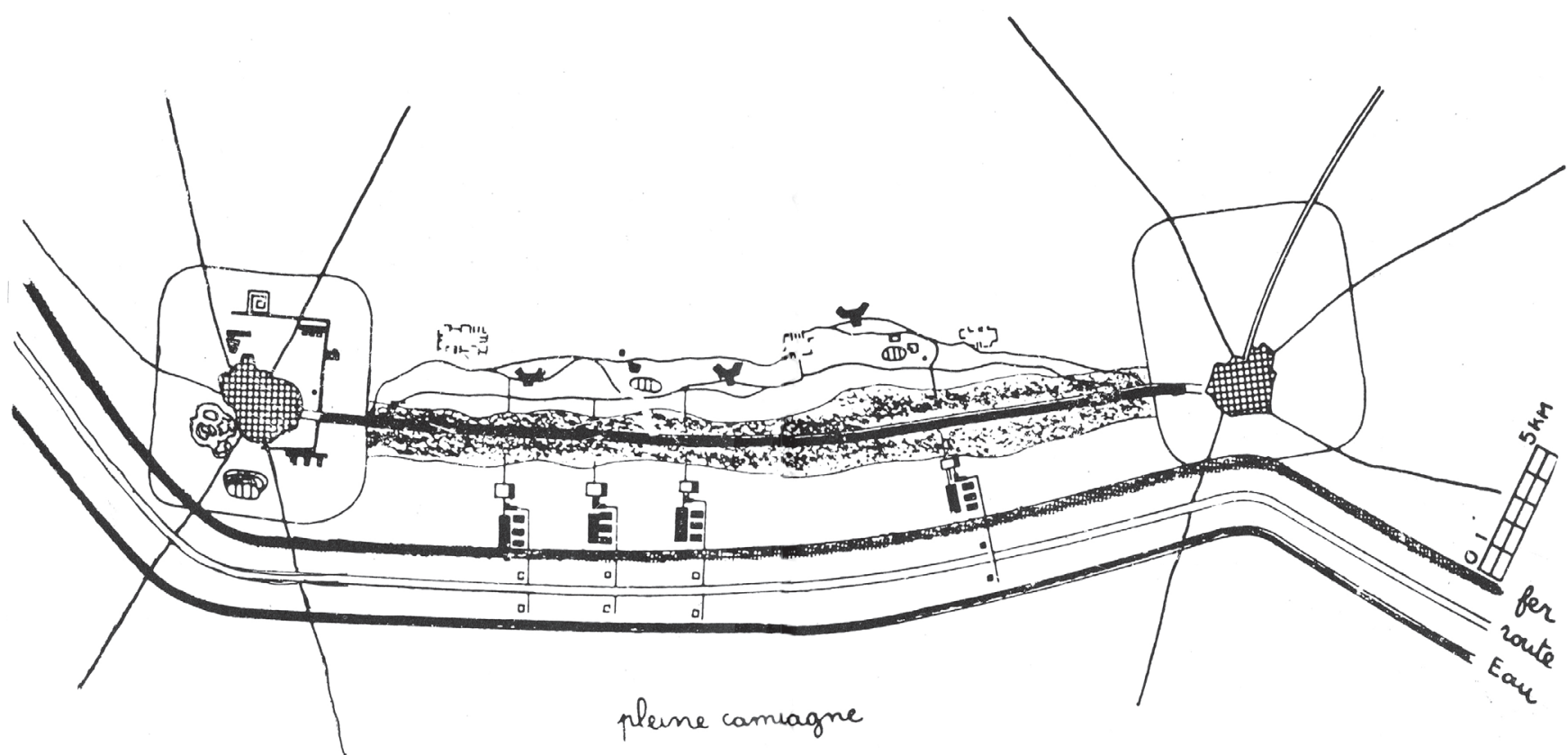

Figura 77: Le Corbusier e sua proposta para uma estrutura regional linear Fonte: LE CORBUSIER, 1979: 124-125 
Ao contrário, Lynch (1981: 377) que afirmava que “(...) the lack of intensive centers is a handicap for the linear city", o Estudo de Colin Buchanan, assim como uma série de outros elaborados ao longo do século XX, parecem caminhar em sentido oposto. A forma de expansão da cidade, recorrentemente tratada nas propostas para as estruturas lineares, partia do princípio da inviabilidade do centro urbano tradicional, caracterizado pelo seu caráter único e articulador de deslocamentos radiais.

De fato, ao que parece, o que está em discussão é a impossibilidade da situação de um centro tradicional diante das transformações na tecnologia de transportes. Ao mesmo tempo, para Colin Buchanan, este discurso parece bastante adequado à opção pelos modos individuais e mecanizados de deslocamento. Em outras palavras, um centro li-

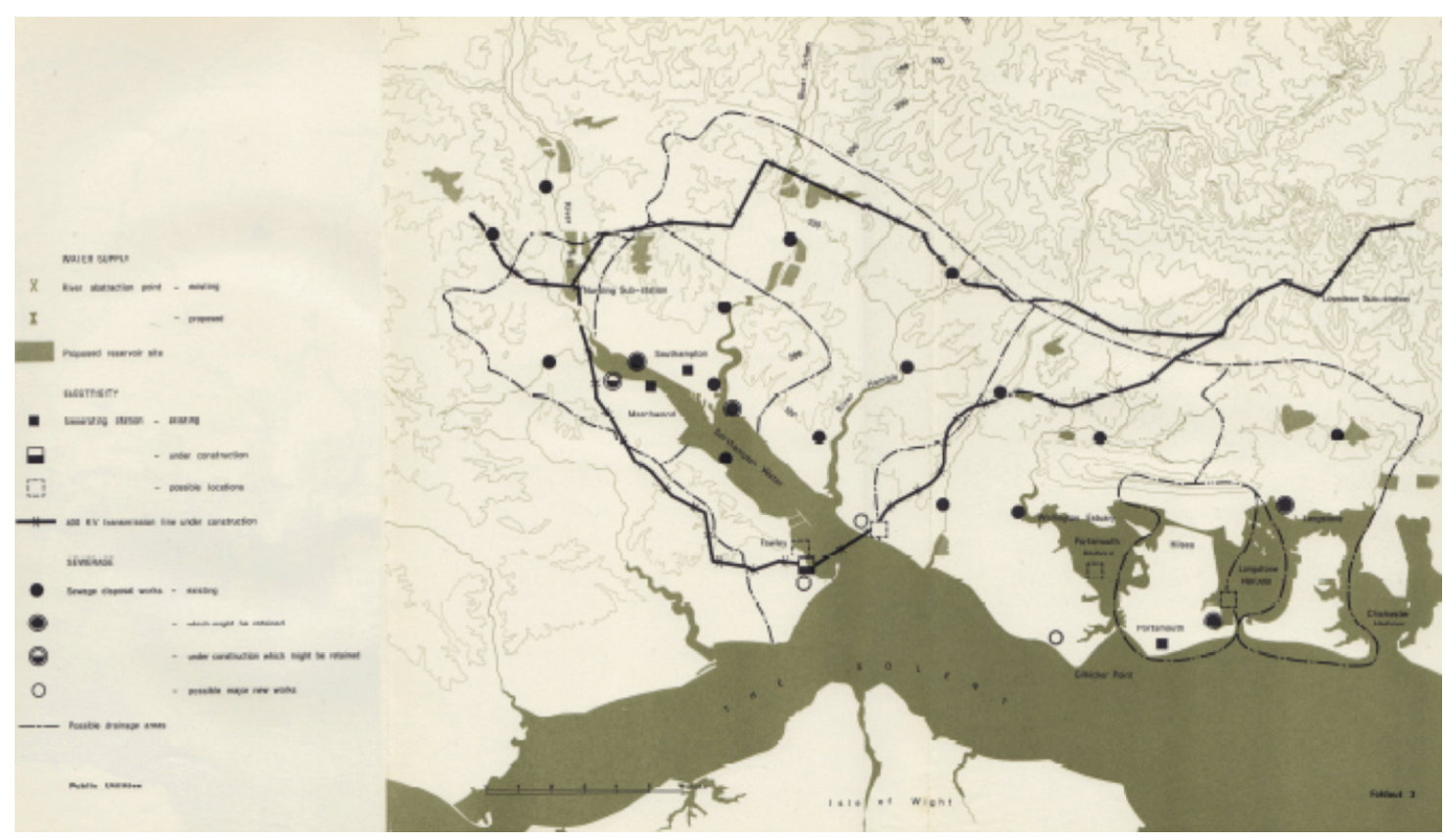

Figura 78: South Hampshire Study, Colin Buchanan\&Partners, 1966 - relevo e infra-estrutura urbana na área de estudo

Fonte: COLIN BUCHANAN \& PARTNERS, 1966, fig 3 
near seria muito mais receptivo aos automóveis no caso da estruturas centrípetas, pelos motivos que já foram discutidos acima.

Mas a equipe do Relatório para South Hampshire reconhecia também os limites deste modelo. De fato, trata-se muito mais de uma estrutura teórica que de uma lógica de organização concreta de cidades, conforme reconhece Lynch (1981: 376): "the concept of a linear city has repeatedly been unfurled as a new theoretical idea, but rarely been applied."

A opinião de Lynch é compartilhada por Doxiadis, em um texto em que refuta enfaticamente o enquadramento de sua teoria sobre o crescimento "harmonioso" dos centros urbanos (Dynapolis) como uma estrutura linear (DOXIADIS, 1970). Para ele, este modelo praticamente não existiria como possibilidade de aplicação concreta na prática profissional. Assim como na avaliação de Colin Buchanan e sua equipe, qualquer expansão fora do eixo principal colocaria a lógica de crescimento a partir de um único eixo em xeque. As únicas possibilidades de ocorrência de uma cidade linear, e assim mesmo muito contestáveis, seriam ditadas pela geografia: as cidades costeiras e nos vales.

Curiosamente, o sítio escolhido para South Hampshire estava situado na orla marítima, numa situação muito próxima àquela admitida como exceção por Doxiadis. Tratava-se de uma faixa de terras encravada entre o mar e áreas mais elevadas, com aproximadamente $10 \mathrm{~km}$ de largura, que se entendia de Southampton a Portsmouth.

\section{A grelha como estrutura urbana}

Finalmente, na avaliação de Colin Buchanan e sua equipe, a estrutura em trama, baseada na distribuição equitativa dos seus elementos e em uma só categoria de vias, seria inviável. Não haveria possibilidades reais de desenvolvimento equilibrado em todas as direções. Na prática, Buchanan indicava seu desejo de não abrir mão do conceito de hierarquia viária, que desde os tempos Mixed Blessing vinha sendo objeto de reflexões. Colin Buchanan já havia realizado incursões exploratórias a respeito da grelha no estudo para 
Centres.

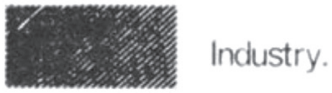

2.

3: - Open Space.

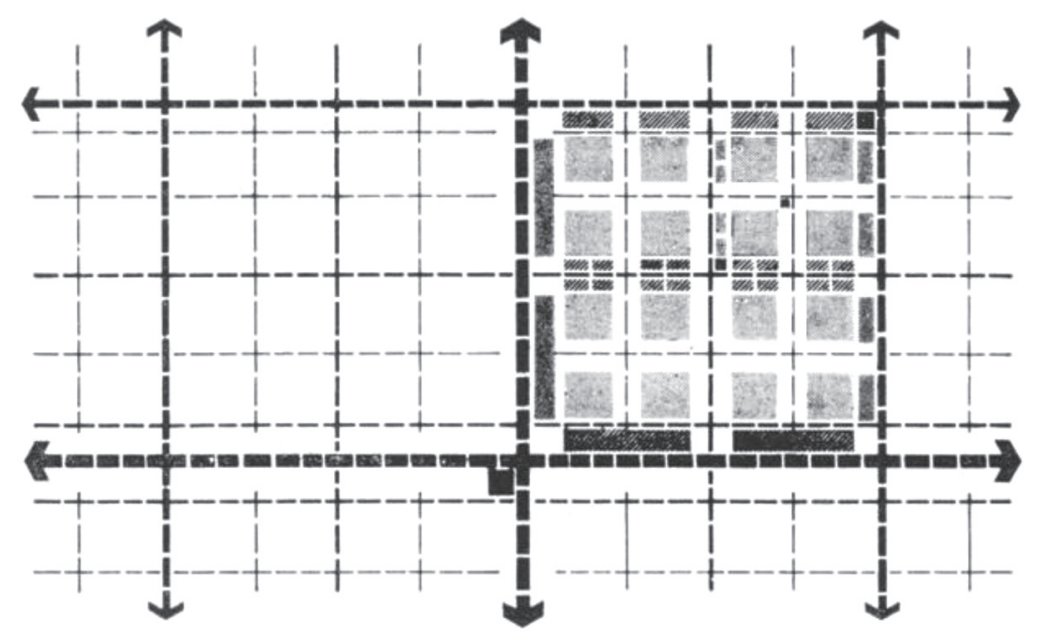

Figura 79: South Hampshire Study, Colin Buchanan\&Partners, 1966 - estrutura urbana em trama Fonte: COLIN BUCHANAN \& PARTNERS, 1970: 23

Londres em Traffic in Towns. Nesta ocasião, investigou possibilidades de distâncias ótimas em relação a abertura da malha.

Em seu lugar, a equipe analisou uma estrutura em trama com diferentes categorias de circulação, "de manera que los nodos de servicios urbanos, de una jerarquía y escala relacionada com las categorías de dicha circulación, podían estar igualmente dispersados en las tramas" (COLIN BUCHANAN \& PARTNERS, 1970: 23).

Estas alterações não surtiram o efeito desejado. Para equipe, haveria o risco de desenvolvimentos diferentes dos nós de centralidade, gerando desequilíbrios e abrindo caminho para a formação de estruturas lineares internas, ligando dois ou mais destes nós com mais vitalidade urbana. Ao fim, declarava: "la trama no se amolda a uma disposicíon de transporte público”38 (COLIN BUCHANAN \& PARTNERS, 1970: 23).

38 O termo utilizado neste caso, "transporte público" deve ser entendido como circulação urbana e não como transporte coletivo. 
A avaliação negativa desta estrutura parece não estar calcada elementos urbanísticos de análise. Seu embasamento não foi discutido da mesma maneira que nos casos anteriores - estruturas linear e centrípeta - mas está ancorado nas simulações de tráfego elaboradas por conta do Estudo e não divulgadas no relatório.

No entanto, chama atenção a escolha desta estrutura como uma das três fundamentais. Ao que tudo indica e como veremos mais adiante, Colin Buchanan não a descarta totalmente, como o relatório do Estudo para South Hampshire poderia, à primeira vista, indicar. O que parece estar em discussão neste caso, é o debate com uma longa tradição histórica desta estrutura e, particularmente, um contraponto com suas manifestações mais contemporâneas.

Segundo Kostof (2006), a grelha, ao longo da história, atendeu a dois propósitos principais: ordenamento da ocupação e modernização frente a uma situação anterior de desordem. Justamente por issoteria sido amplamente utilizada:

"The grid - or gridiron or checkerboard - is by far the commonest pattern for planned cities in history. It is universal both geographically and chronologically (though its use was not continuous through history). No better urban solution recommends itself as a standard scheme for disparate sites, or as a means for the equal distribution of land or the easy parceling and selling of real estate.” (KOSTOF, 2006: 95)

No entanto, a avaliação desta estrutura no caso de South Hampshire parece estar muito mais relacionada à sua compreensão e aplicação a partir do Movimento Moderno e seus desafios relacionados à escala e à mobilidade. Neste sentido, interessa verificar como Buchanan se relacionava com as duas mais importantes formulações da estrutura em grelha no século XX.

Conforme Bernardo Sechhi, Ville Radieuse, de Le Corbusier, e Broadacre City, de Frank Lloyd Wright, foram as contribuições mais importantes no que diz respeito à forma de pensar a cidade, daquilo que denomina a "grande geração". Seriam ainda mais textos 


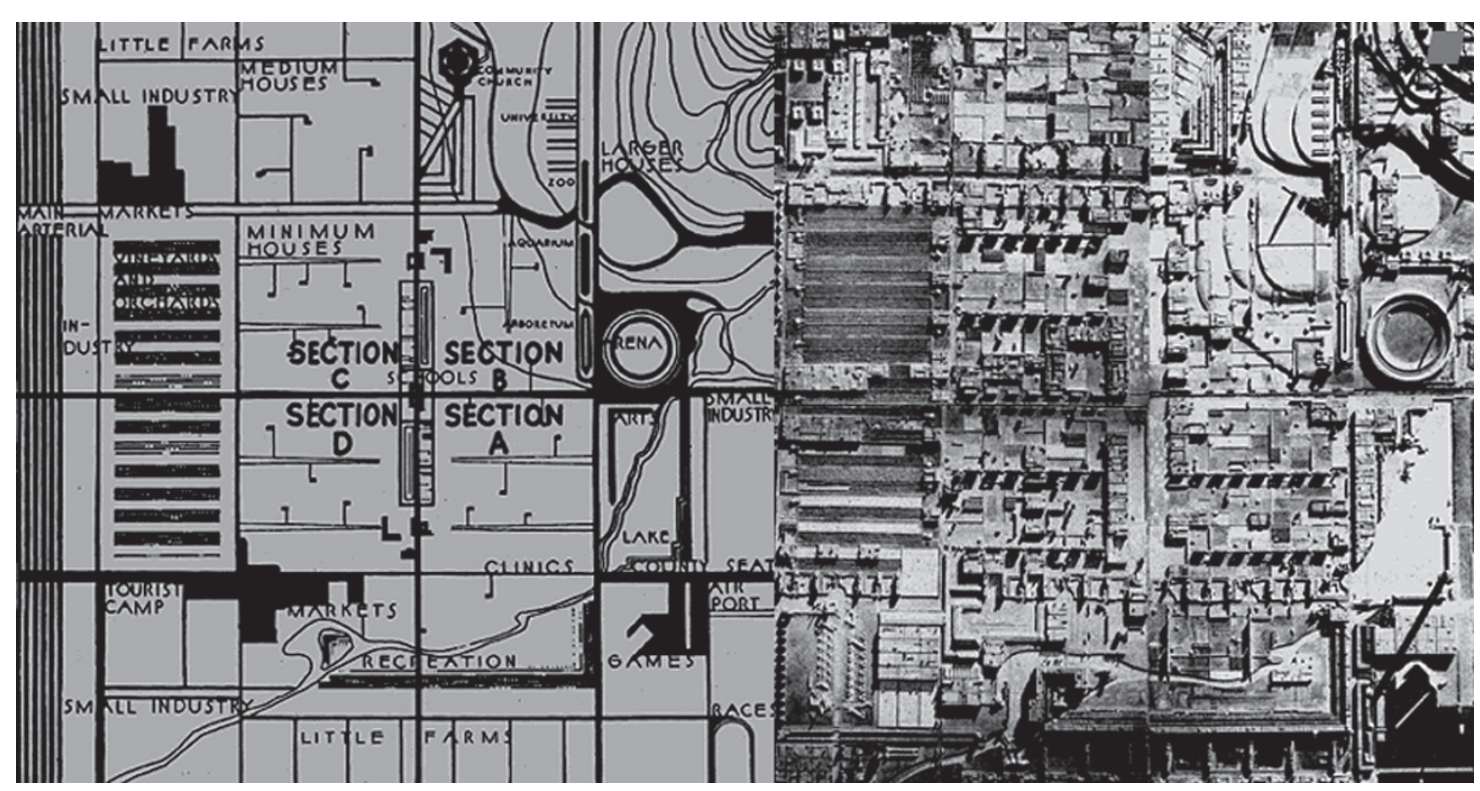

Figura 80: Broadacre City - Frank Lloyd Wright

Fonte: http://www.medienarchitektur.at

manifestos que projetos ou planos ${ }^{39}(\mathrm{SECCHI}, 2009)$.

“(...) Estrutura de ordem por excelência, a malha constrói, em ambos os casos, um espaço urbano aberto e flexível, que se pode expandir em vastos territórios. Em ambos os casos, portanto, existe a rejeição do peso da história, a urgência de uma arquitetura da cidade esteticamente pura e despojada das influências do passado". (SECCHI, 2009: 131).

Embora partindo de um esquema conceitual análogo, a grelha para Corbusier e Wright tem significados distintos. Desde a visão de natureza até o espectro de influências que as sustentam, as duas aplicações desta estrutura urbana têm fundamentações e desdobramen-

39 A "grande geração", segundo Bernardo Secchi, é composta pelos arquitetos que nasceram no final do século XIX (SECCHI, 2009: 119). 


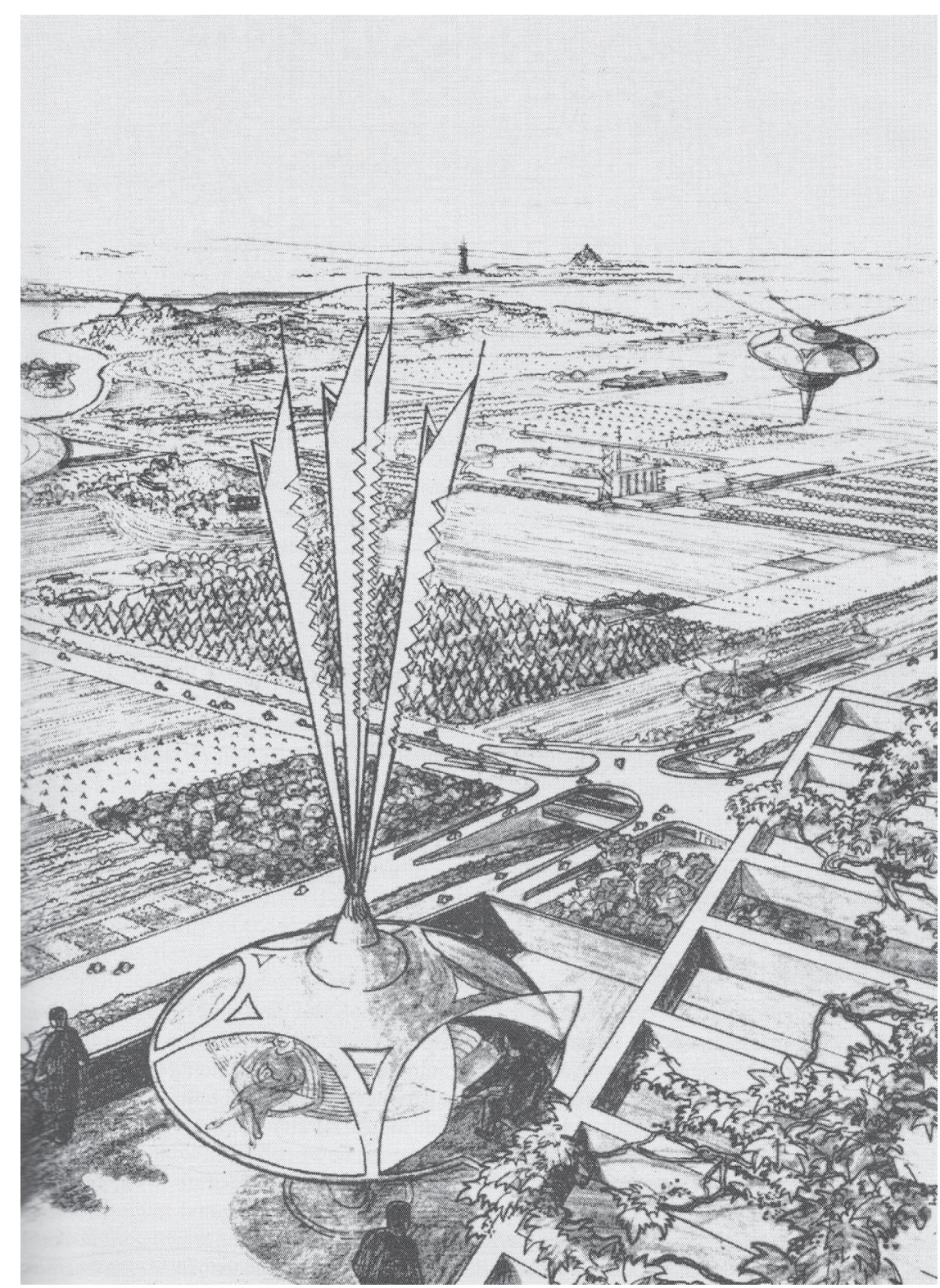

Figura 81: Perspectiva de Broadacre city - Frank Lloyd Wright Fonte: HALL, 2002: 47

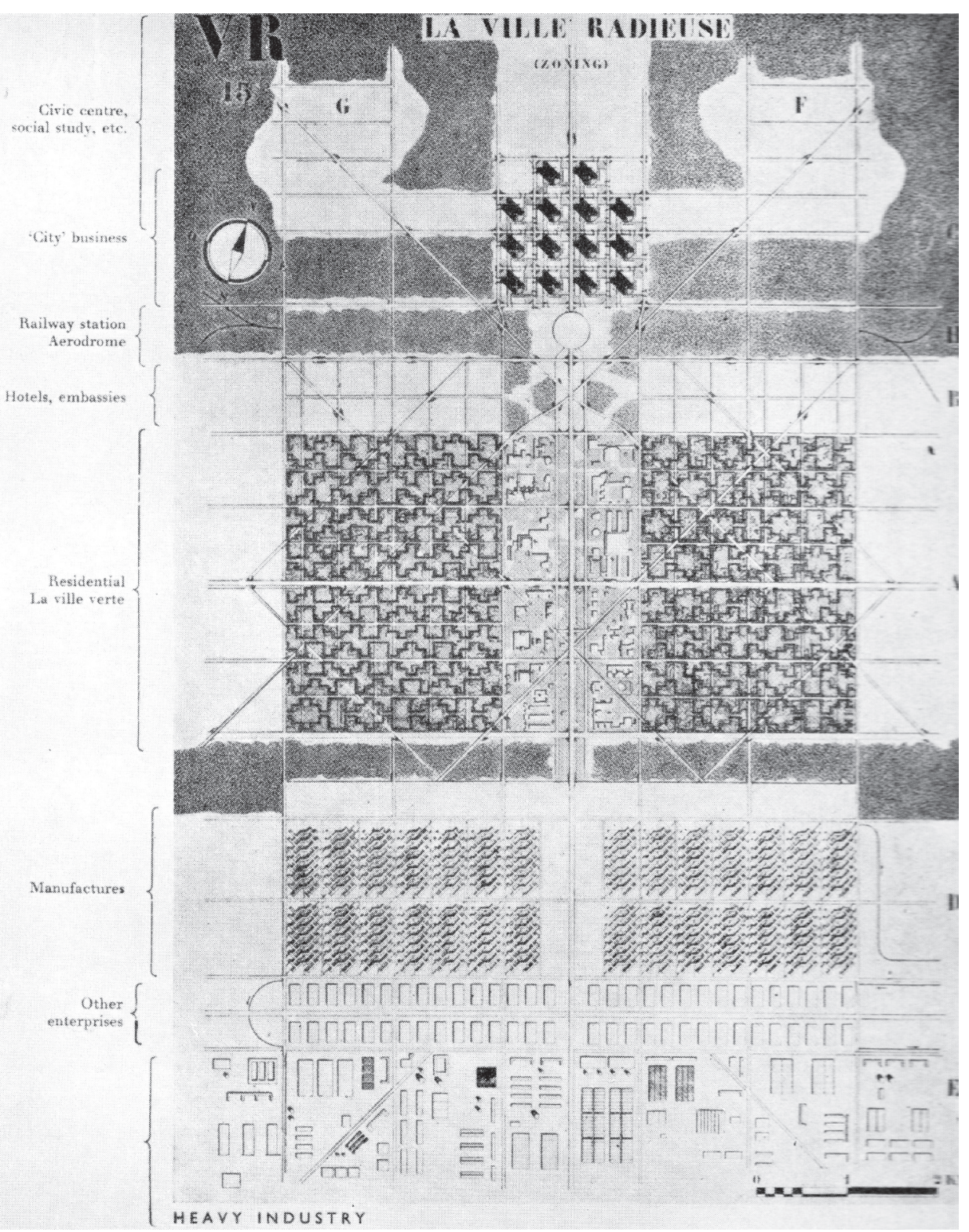

Figura 82: Vila Radiosa - Le Corbusier

Fonte: NITSCHKE, 1966: 169 
tos muito diferentes ${ }^{40}$. Entretanto, os diferentes desdobramentos da grelha se utilizam de uma de suas principais características - a sua grande capacidade de adaptação aos mais diversos objetivos - responsável por sua longa permanência na história do urbanismo. Conforme KOSTOF (2006: 157), “(...) The virtue of the grid is precisely in being a conceptual formal order, nonhierarchical, neutral, until it is infused with specific content (...)”

No caso da Broadacre City de Wright, interessa destacar o significado da grelha na sua dimensão política e sua adaptação à lógica de mercado, baseada na sua flexibilidade. Para Frank Lloyd Wright a grelha se fundamenta na malha jeffersoniana que tinha permitido medir e colonizar todo o território dos EUA, na qual

"mitologicamente, era representada uma forma de democracia que nasceu nos grandes territórios do novo continente (...). Na origem do pensamento de Wright existe a idéia de que o ruralismo seja a base da democracia americana (...)" (SECCHI, 2009: 131).

Em outras palavras, no seu estudo para Broadacre City, a grelha para Frank Lloyd Wright era muito mais um instrumento de parcelamento do solo urbano do que uma trama de suporte à mobilidade, ainda que fosse formada pelo conjunto de vias de grande capacidade de tráfego.

Essa concepção, no entanto, sofreu um grande redirecionamento a partir de Manhattan. Se na época da colonização norte-americana a grelha se constituiu numa malha "fechada", após Manhattan o grid passou a se configurar como malha "aberta". No primeiro caso, o conceito era essencialmente pré-capitalista: definia um limite preciso para a cidade, com seus edifícios públicos em seus eixos e áreas rurais no entorno, que não poderiam ser vendidas. Tratava-se da divisão da terra entre os colonos. No segundo caso, a trama aberta, tratava-se de uma estrutura em conformidade com a lógica capitalista. A terra transformara-se em mercadoria e a cidade, como o mercado, não poderia apresentar limites à expansão. Em outras palavras, seria o mercado o elemento

40 A este respeito ver SECCHI (2009: 131-133) 
que definiria os limites da cidade (KOSTOF, 2006). Por isso, o edifício, o lote e a via se manteriam associados no estudo para Broadacre City.

Muito diferente seria a visão da propriedade da terra para Le Corbusier. Ao contrário de Wright, Corbusier concebia o solo urbano como propriedade pública, portanto livre dos limites dos lotes. Assim, a grelha para o arquiteto franco-suíço era muito mais uma infraestrutura para a circulação, que um elemento definidor de limites. Sua conhecida contraposição entre os edifícios lâmina da Vila Radiosa e as cidades de Paris, Nova Iorque e Buenos Aires evidencia a completa independência entre os elementos edificados e as vias.

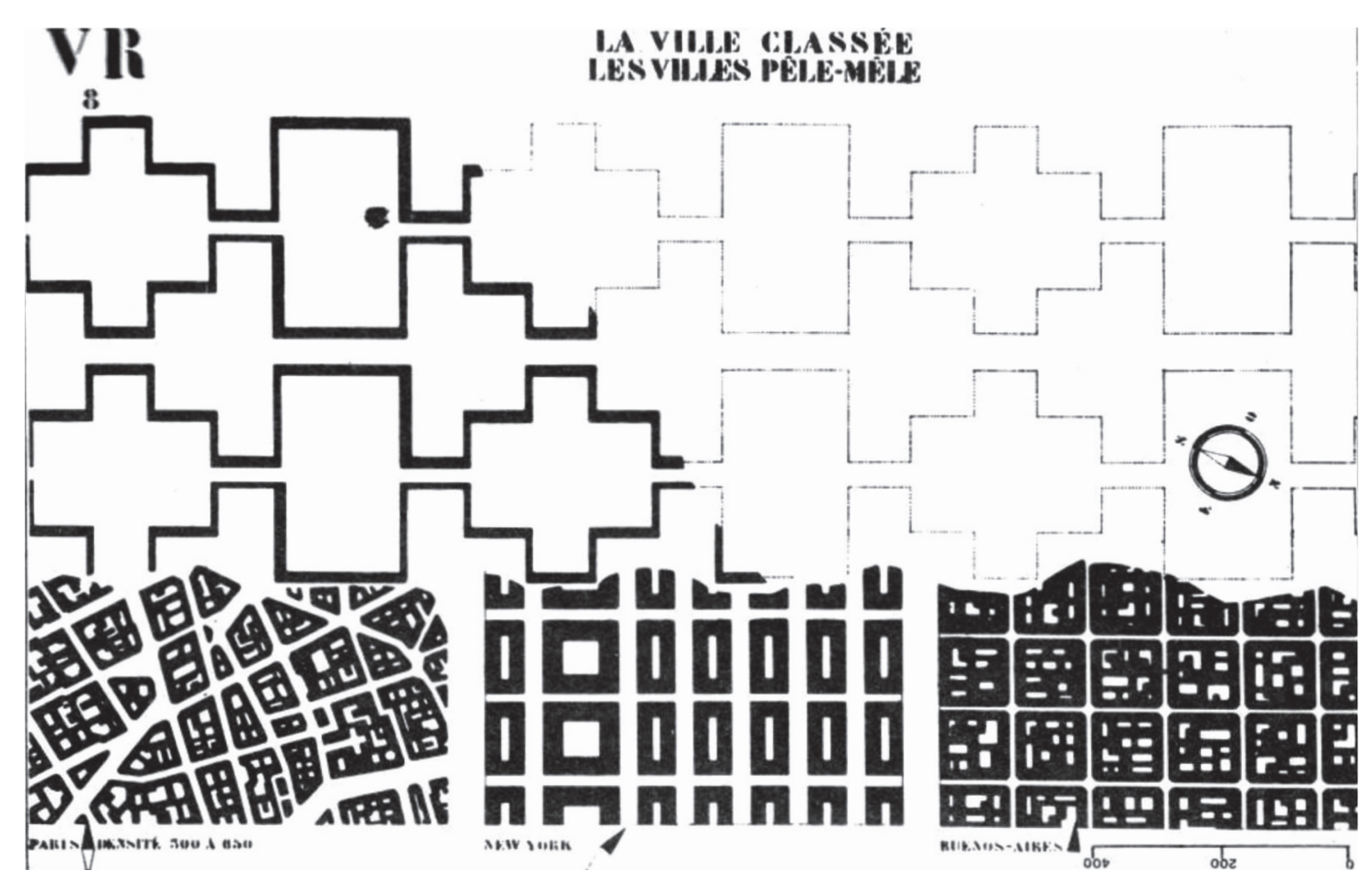

Figura 83: Comparação entre as malhas de Paris, Nova Iorque, Buenos Aires e a proposta para Vila Radiosa - Le Corbusier Fonte: BENEVOLO, 2009: 632 
Sua conhecida proposta de edifícios sobre pilotis geraria uma cidade em que os automóveis e os edifícios obedeceriam a lógicas completamente diferentes de implantação no território. Enquanto a implantação dos edifícios seria resultado de critérios como insolação e proporção entre o distanciamento dos blocos e suas alturas, a localização das vias obedeceria a ditames fornecidos pela lógica do movimento. Assim, o automóvel demandaria canais em que o seu melhor desempenho pudesse ser atingido, resultando numa malha de vias retilíneas.

Este raciocínio parece permanecer presente na concretização de sua idéia de cidade: o

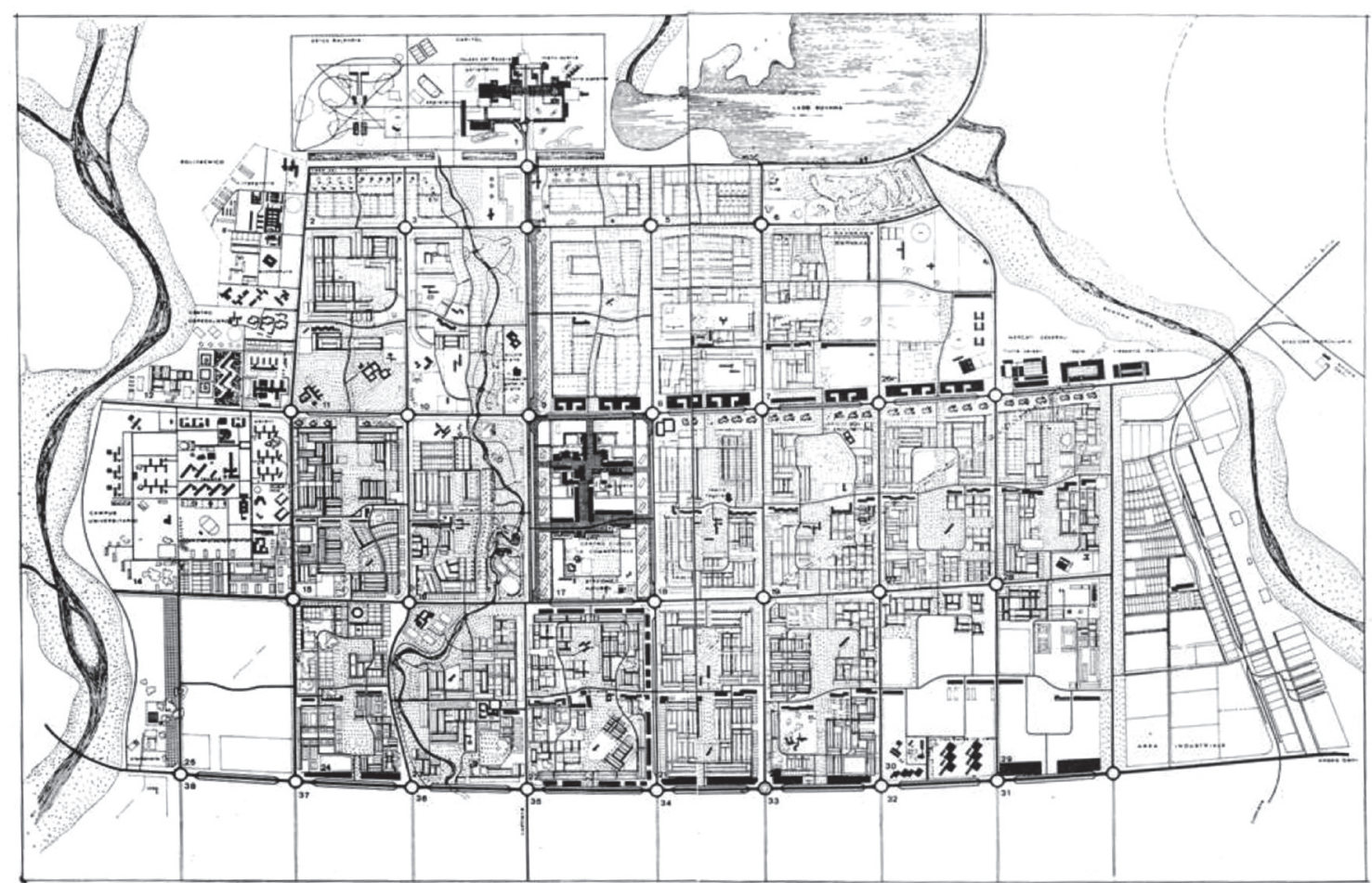

Figura 84: Projeto para Chandigarh - Le Corbusier, 1951 Fonte: BENEVOLO, 2009, 707 
Plano para Chandigarh, elaborado em 1951. Aqui, embora a trama de vias em grelha dê forma à cidade, as habitações e o restante dos edifícios obedecem a outro raciocínio de implantação. De fato, o sistema viário estabelece uma "estrutura" que pode ser preenchida de diferentes maneiras, conforme os ajustes necessários em cada caso.

Corbusier, neste sentido, permaneceria fiel à proposição dos seus cinco pontos da arquitetura moderna, mais particularmente, o da estrutura independente da vedação. Um sistema estrutural de lógica clara deveria abrigar diferentes disposições internas. Ao mesmo tempo, assim como as paredes dos edifícios impediriam a desejável circulação do ar, os próprios edifícios implantados à maneira tradicional comprometeriam o deslocamento dos meios mecanizados de transporte.

Kostof (2006) ressalta que, a partir deste conceito, a trama formada pela grelha se tornou um conjunto de células sitiadas depois do advento do automóvel. E a quadra pas-
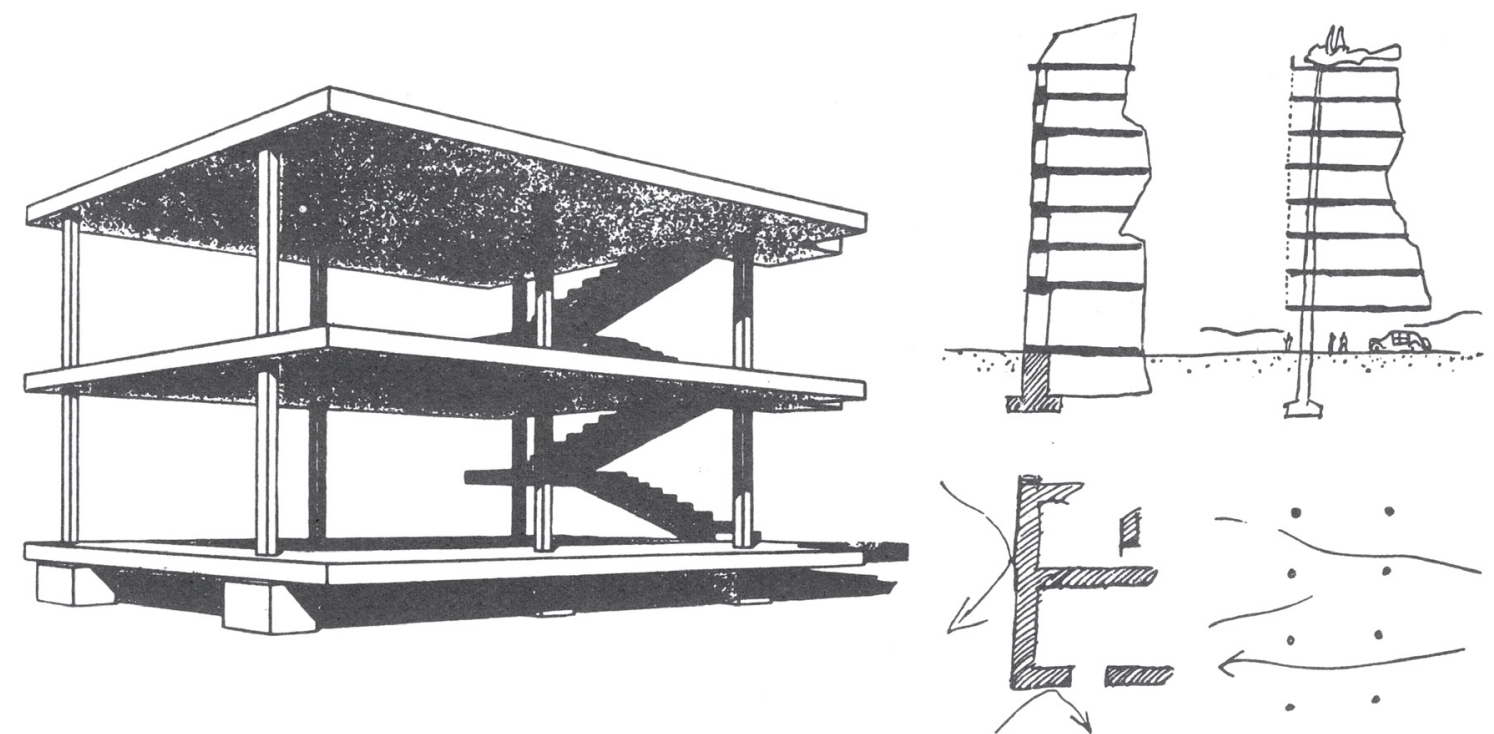

Figura 85: Conceito estrutural da Casa Dominó - Le Corbusier, 1914 Fonte: BENEVOLO; MELOGRANI; LONGO, 1977: 34 
sou a ser concebida como uma unidade autônoma e não como meio de organizar lotes individualmente, merecendo até mesmo um zoneamento específico.

Estas duas referências do Movimento Moderno chegam aos anos 1960 já bastante difundidas entre os urbanistas. Na maioria dos casos não se trata da opção de uma pela outra, mas da mixagem de elementos de ambas, como em Doxiadis, ou mesmo da crítica de sua pretensa equivalência da trama, como em Kevin Lynch.

Doxiadis, no já mencionado livro "Ekistics: an introduction to the science of human settlements", de 1968, deixa clara sua opinião a favor da grelha: "When evolution reaches the stage at which a rectilinear pattern develops into a regular grid-iron one, man has made his greatest discovery in the synthesis of human settlements" (DOXIADIS, 1968: 204).

Seu principal discurso de defesa da grelha está ancorado na idéia de cidade flexível. Para ele, tratava-se de um processo evolutivo a caminho do maior ordenamento possível dos assentamentos humanos. Assim, as "forças centrípetas" iniciais de um núcleo urbano conduziriam a uma conformação radial-perimetral. Estas mesmas forças tornariam os assentamentos maiores dificilmente manejáveis, gerando ainda uma difícil transição entre núcleo central e periferia. Finalmente, o grid-iron permitiria um arranjo condizente com o grau de desenvolvimento humano e sua necessidade de flexibilidade.

No mesmo período, Kevin Lynch consolidava seus estudos de campo em Boston, Jersey City e Los Angeles, mostrando que a percepção dos habitantes poderia ser radicalmente diferente daquilo que era concebido como plano. Neste sentido, propunha outra matriz de análise baseada em cinco categorias perceptivas (via, limite, ponto nodal, bairro e marco urbano). Lynch assim deslocava o centro da ciência urbana das duas dimensões do plano no papel, para pelo menos três dimensões da percepção humana do espaço.

O resultado obtido para as três cidades, mas particularmente Los Angeles - uma cidade reconhecidamente organizada a partir da grelha - era surpreendente. A estrutura da cidade praticamente se diluía como forma e se transformava numa trama viária hierarquizada.

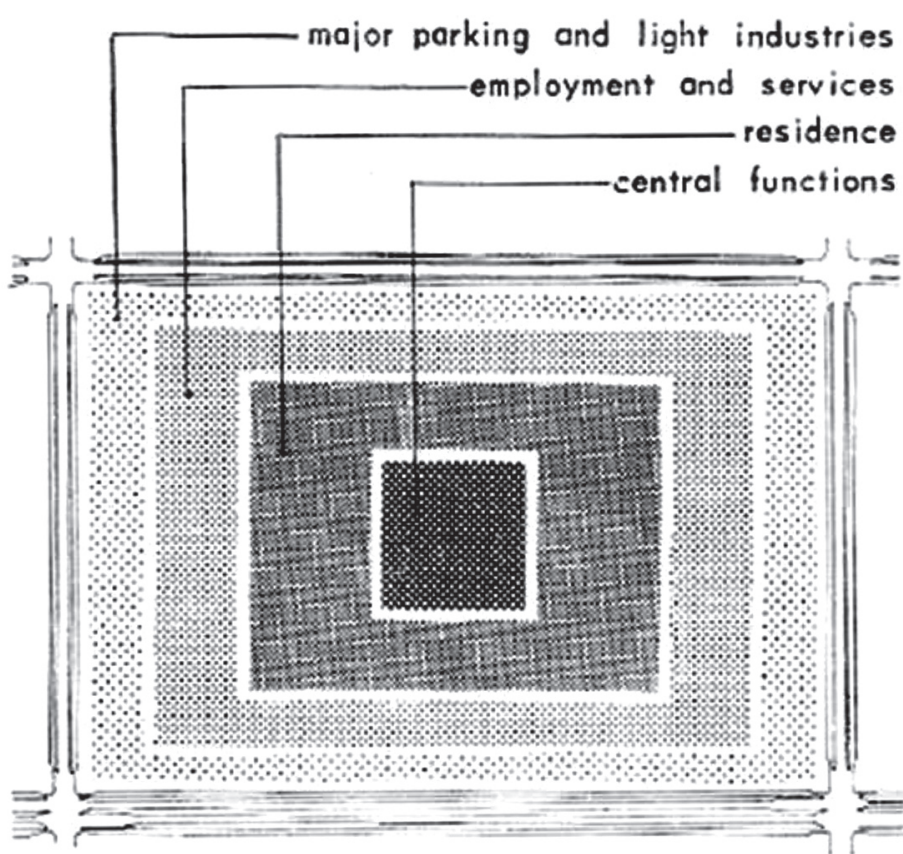

Figura 86: Zoneamento interno dentro de uma célula da estrutura em grelha

Fonte: DOXIADIS, 1968: 364
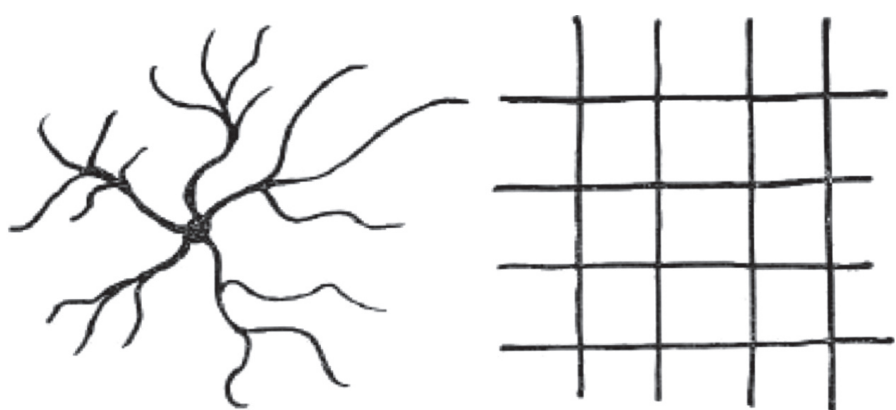

one choice and one point of control versus

a maximum of chaices

Figura 87: Comparação entre a estrutura rádio-concentrica e em grelha, conforme Doxiadis

Fonte: DOXIADIS, 1968: 204 
tendency to achieve an orderly pattern

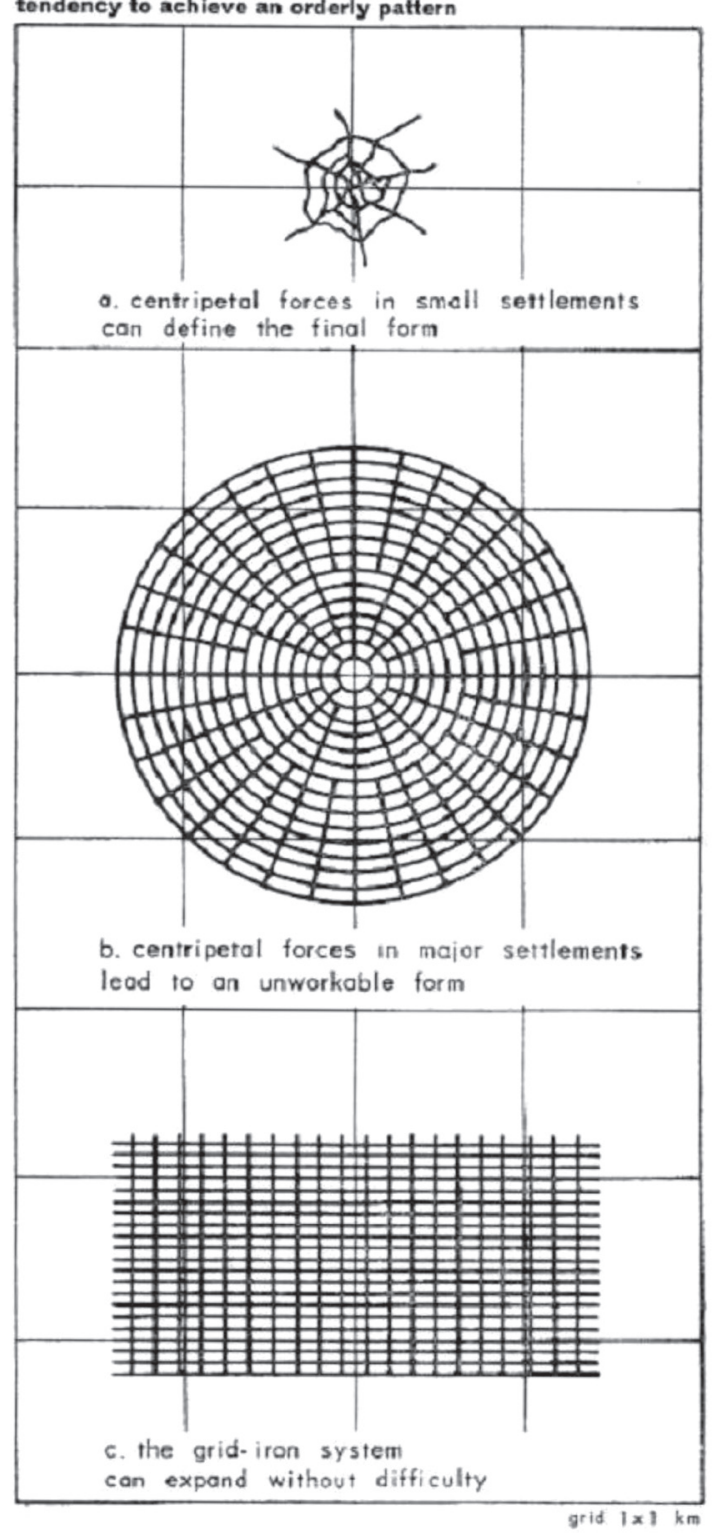

Figura 88: Tendência a arranjos urbanos mais ordenados, conforme Doxiadis Fonte: DOXIADIS, 1968: 313
Interessa neste caso reconhecer a proximidade deste discurso de Lynch com as críticas elaboradas por Colin Buchanan e sua equipe por ocasião da análise das estruturas urbanas. Em Los Angeles, conforme as categorias de análise de Lynch, a trama acabava por gerar desenvolvimentos desiguais e as vias se configuravam como articulares de usos, transformado-as elas próprias em centralidades.

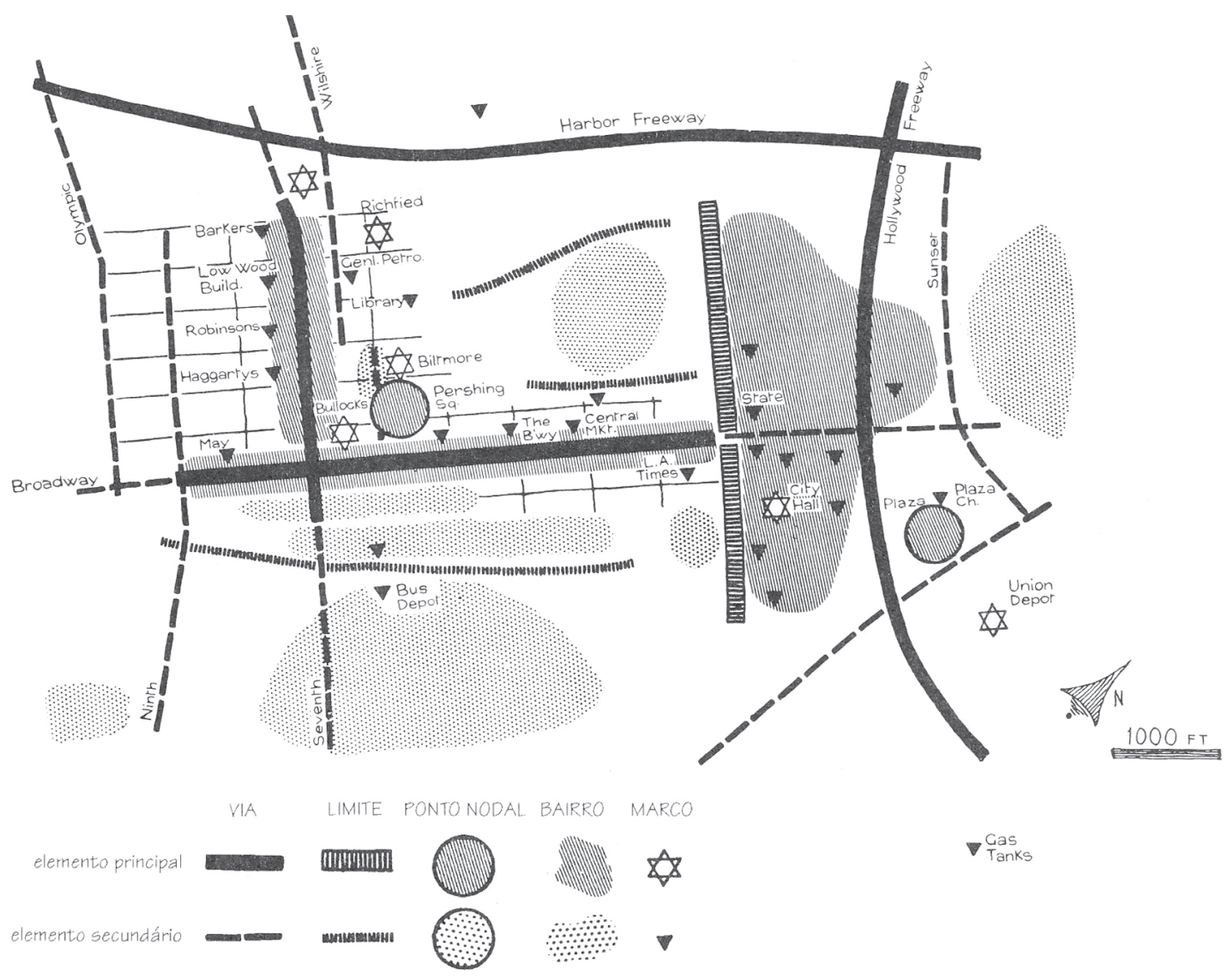

Figura 89: A apreensão em campo da Cidade de Los Angeles, conforme Kevin Lynch Fonte: LYNCH, 1997: 37 
As referências de Buchanan à experiência norte-americana, no que diz respeito à trama, são recorrentes. Na palestra que ministrou no Instituto de Engenharia em São Paulo em 1966, o engenheiro-urbanista britânico se desculpava pela falta de tempo para se estender sobre o assunto, mas alertava que a solução em grelha, amplamente aplicada nos Estados Unidos, mereceria grande atenção e estudo (BUCHANAN, 1967)

\section{A trama direcional, a relação entre cidade e circulação e a dimensão regional}

No Estudo para South Hampshire, Colin Buchanan e sua equipe não optaram efetivamente por nenhuma das tipologias analisadas: grelha, radio-concêntrica e linear. A rápida descrição da avaliação dos três tipos elementares parece ter sido utilizada somente

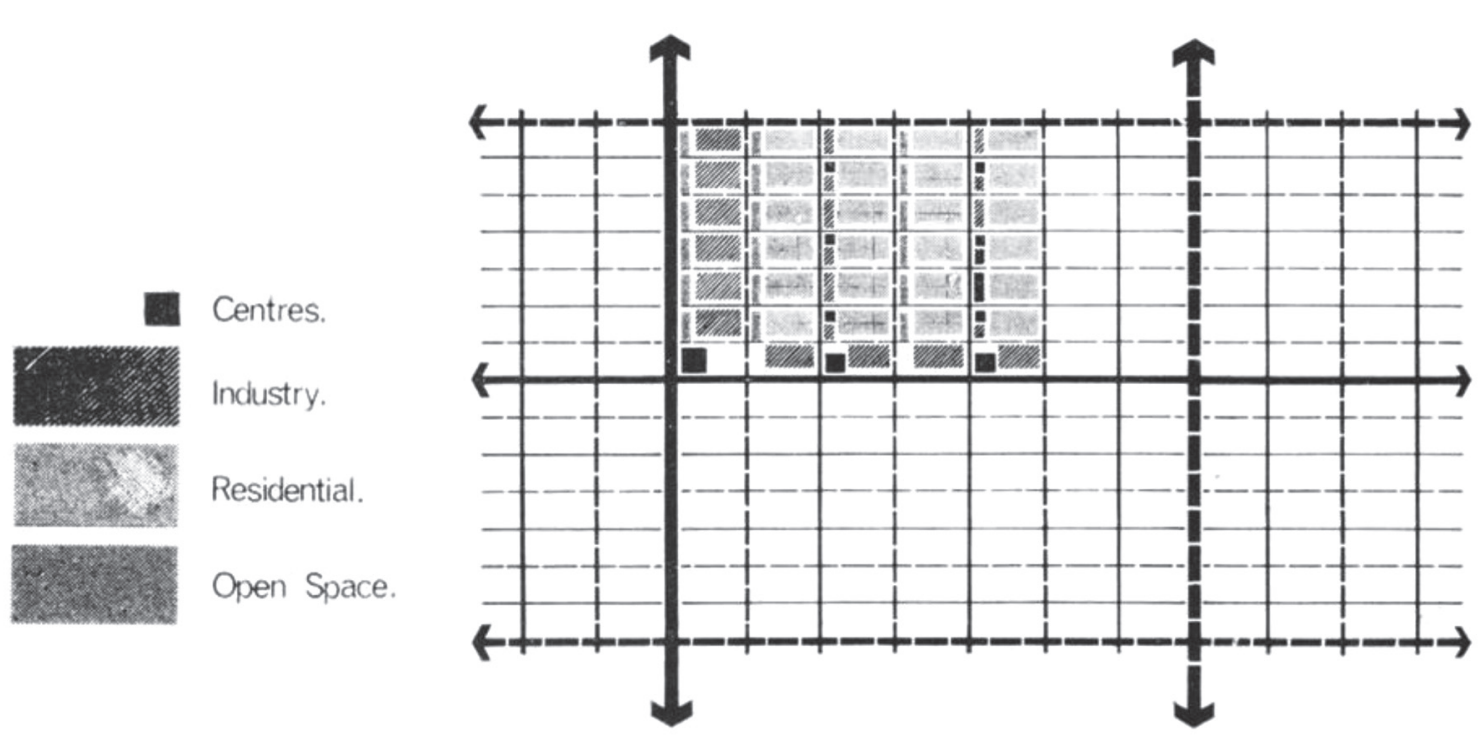

Figura 90: South Hampshire Study, Colin Buchanan\&Partners, 1966 - estrutura urbana em trama direciona Fonte: COLIN BUCHANAN \& PARTNERS, 1970: 23 

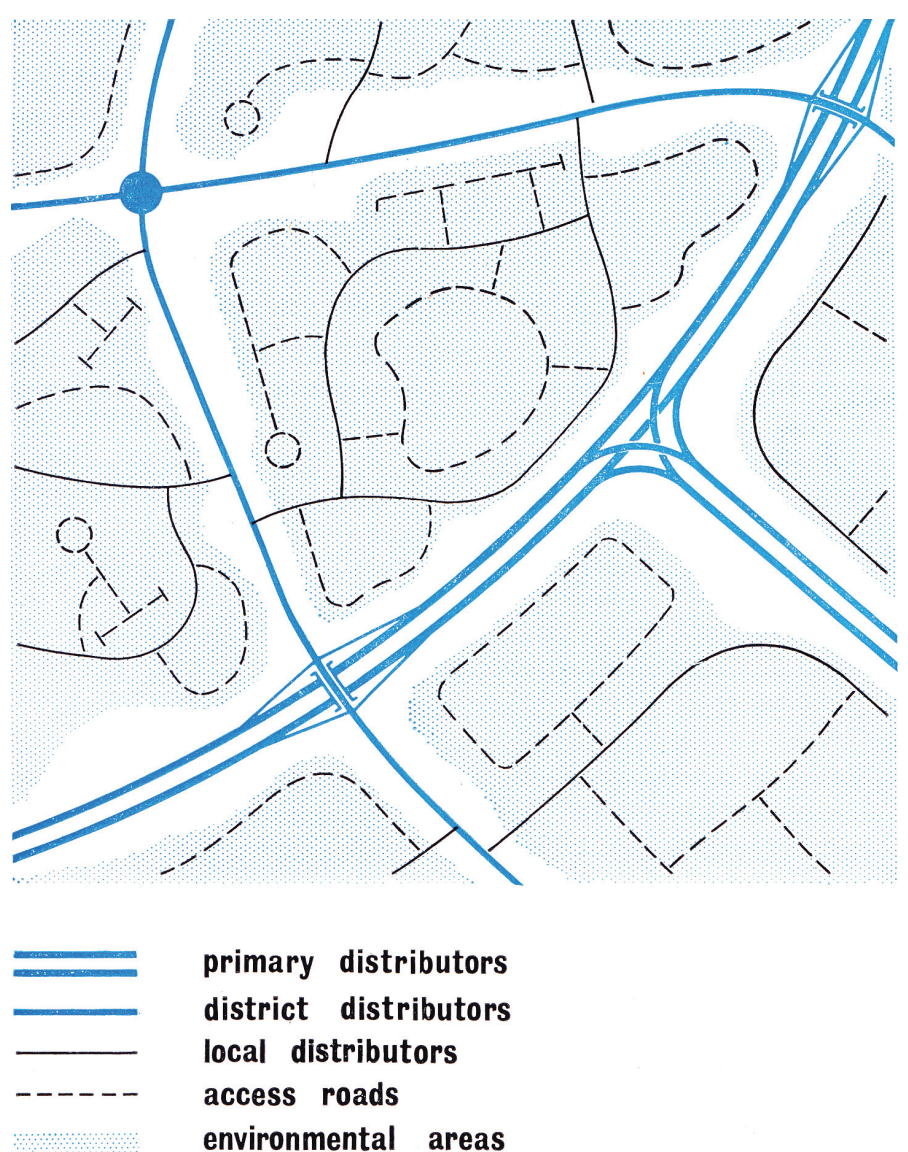

Figura 91: Hierarquia viária conforme o manual Roads in urban Areas

Fonte: MINISTRY OF TRANSPORT, 1966: 9 como um recurso para demonstrar a inadequação das estruturas urbanas tradicionais e como embasamento para justificar a formulação daquilo que seria uma nova alternativa para a era dos transportes motorizados: a trama direcional.

Ao recuperar as três estruturas consideradas elementares, a equipe do Estudo se posicionava em relação à diferentes tradições urbanísticas e as avaliava sob o prisma de critérios de desempenho. De Le Corbusier a Howard, passando pelo Casal Smithson, o Estudo para South Hampshire estabelecia um diálogo com a história do urbanismo e propunha uma nova estrutura urbana para a era da massificação dos transportes sobre pneus.

As considerações não estavam ancoradas na relação entre sítio natural e cidade, nem mesmo em relação à história, mas fundamentadas em dois critérios de desempenho: flexibilidade e transportes. Por isso a avaliação da estrutura era tão importante, pois se configurava em algo que ao mesmo tempo definiria os sistemas possíveis de transportes e garantiria as transformações urbanas que naturalmente ocorreriam. Ambos os critérios estavam ainda extremamente vinculados, já que a flexibilidade era algo característico dos modos sobre pneus, como admitimos anteriormente.

A estrutura em trama direcional adotada no Estudo afirmava a relação indissociável entre a cidade e sua lógica de circulação. Não por acaso, muitos dos planos de Colin Buchanan como consultor neste período são trabalhos de planejamento e transportes associados, como os casos dos estudos para Bath (1966), Kuwait (1970) e Edinburgh (1972).

Neste sentido, é revelador que Buchanan tenha abandonado sua própria proposta de hierarquia viária formulada em Traffic in Towns, que neste momento já era adotada oficialmente pelos manuais de projetos viários britânicos ${ }^{41}$. De fato, a classificação em primary distributors, district distributors, local distributors e access roads traduzia uma hierarquização baseada apenas nos tipos de movimento, mas desvinculadas das atividades que se processavam ao longo das vias.

41 A este respeito ver: "MINISTRY OF TRANSPORT. Roads in urban areas. London, Her Majesty's Stationery Office, 1966" e "IHT - INSTITUTION OF HIGHWAYS AND TRANSPORTATION. Roads and Traffic in Urban Area. London, HMSO Books, 1987" 
Ao contrário, a hierarquia de vias proposta no Estudo para South Hampshire era bem mais complexa que a anterior:

"La red de transporte consiste en uma trama de circulaciones de categorias diversas. Las circulaciones de una misma categoría forma ángulo recto con las de categoría superior o inferior a ellas. Las categorías de dichas circulaciones estan em relación con los subsistemas urbanos a los que abastecen. Para una fácil identificación, hemos diferenciado estas vías de circulación numerándolas de 1 al 6 . Por ejemplo, las circulaciones 1 y 2 corresponden, em las subestructuras, a sendas e calles locales. Em el outro extremo de la escala las circulaciones ' 6 ' corresponderían a líneas de comunicación regional y nacional”. (COLIN BUCHANAN \& PARTNERS, 1970: 21)

A hierarquia de vias proposta teria ainda uma segunda subdivisão: vias vermelhas e vias verdes. As primeiras eram definidas como "eixos de atividade", bastante relacionadas aos usos lindeiros; enquanto as segundas estariam implantadas em meio a zonas verdes, mais destinadas à circulação de veículos e à ligações expressas de transporte coletivo. Nas vias vermelhas, transporte público e privado compartilhariam espaços e suas interseções seriam geradoras de centralidades. Assim, a localização das atividades seriam geradas a partir da associação de vias de categoria 4 e 5 ou 3 e 4 e assim por diante. Ao contrário, as vias verdes não se associavam a usos lindeiros relacionados ao movimento de pedestres.

Embora a trama direcional gerasse uma série de células formadas pelas vias do entorno, eram as vias que determinariam as atividades e não o contrário. Em outras palavras, em vez de definir o perímetro de zonas de atividades e posteriormente classificar as vias, segundo seus usos lindeiros e as atividades ali estabelecidas, a configuração da rede hierarquizada era o que determinaria o tipo de uso do solo. É por esta razão que na mesma célula seria possível a convivência de usos residenciais, pequenas industriais, escolas, comércios e serviços.

Neste sentido, Colin Buchanan aponta uma diferença essencial com a corrente do pla- 
nejamento de transportes desenvolvida nos Estados Unidos no período pós II Guerra Mundial. A metodologia, que ficou conhecida como UTPS, foi desenvolvida nos anos 1950 e previa um conjunto de técnicas para a análise das demandas de transportes, consistindo em quatro etapas: geração, distribuição, divisão modal e alocação. A escolha final da alternativa era baseada finalmente num estudo de viabilidade econômica financeira (VASCONCELLOS, 1996). Ou seja, enquanto o método desenvolvido pelos norteamericanos avaliava a geração de viagens a partir de uma situação urbana dada, em South Hampshire tratava-se de formular uma nova estrutura urbana, em que a relação entre uso do solo e viagens estaria para ser proposta, mais do que simplesmente prevista.

Nesta nova proposta de hierarquia de vias associada ao uso do solo a noção de environmental areas também se relativizava. Antes, seu significado estava extremamente associado à definição de limites espaciais claros, conferidos pelo sistema viário estrutural (primary distributors e district distributors). Na nova proposta, este conceito deixava de se apresentar com uma área urbana para se colocar como uma característica rela-
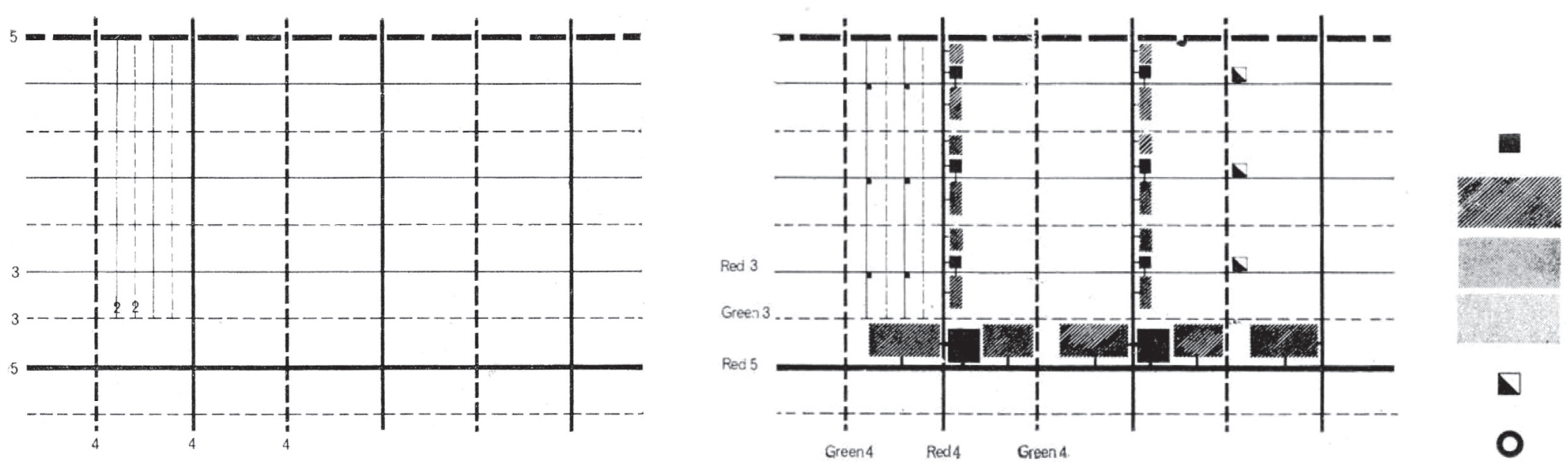

Retail and office centres

Industry

Residential

Open space

Schools

- Office centres

Figura 92: South Hampshire Study, Colin Buchanan\&Partners, 1966 - hierarquia de vias e relação do sistema viário com os usos do solo Fonte: COLIN BUCHANAN \& PARTNERS, 1970: 24 
cionada às vias. Do conceito formulado em Traffic in Towns, permaneceu apenas seu aspecto fundamental: a preocupação com o estabelecimento de padrões ambientais que limitassem o uso abusivo dos veículos motorizados, ou na definição de Buchanan, environmental capacity. Em South Hampshire a hierarquia proposta continha, em si, os diferentes níveis de padrões ambientais. Assim, as vias tipo 1 apresentariam as maiores restrições aos automóveis, enquanto as vias tipo 6 demandariam preocupações bem menores neste sentido.

O Estudo para South Hampshire parece dar um novo destino às soluções em grelha, como estrutura urbana. Se, conforme afirmou Kostof (2006), as células formadas pela trama em grelha haviam se tornado progressivamente sitiadas pelo automóvel, o Estudo para South Hampshire abria uma perspectiva inovadora nesta relação entre via e uso do solo. Assim, embora existisse proximidade entre a hierarquia viária proposta no Estudo britânico e aquela empregada por Le Corbusier para o Plano de Chandigarh, entre ambas havia também uma distinção fundamental. Enquanto em Chandigarh a questão era a separação entre as funções de circulação e habitação, em South Hampshire, a hierarquia viária acabaria por se transformar em uma "hierarquia urbana", organizando e relacionando simultaneamente uso do solo e movimento.

Esta hierarquia urbana estava relacionada com aquilo que podemos denominar de "unidade básica de planejamento". Esta unidade, de aproximadamente 4 km X 6 km, abrigava as classes previstas no Estudo para South Hampshire: as vias verdes e vermelhas, desde a categoria 1 até a $5^{42}$. A estas classes estavam associados os diferentes usos do solo e a distintas densidades demográficas previstas para os usos habitacionais.

Ao longo da via de classe 5 - vermelha estavam previstos usos relacionados à geração de emprego e, portanto, de atividades - ligadas basicamente comércio e à indústria. A interseção destas com as vias de classe 4 - vermelha gerariam centralidades que se

42 A categoria 6 abrigava movimentos rodoviários e portanto estava fora da unidade básica de planejamento, que tinha um caráter urbano.

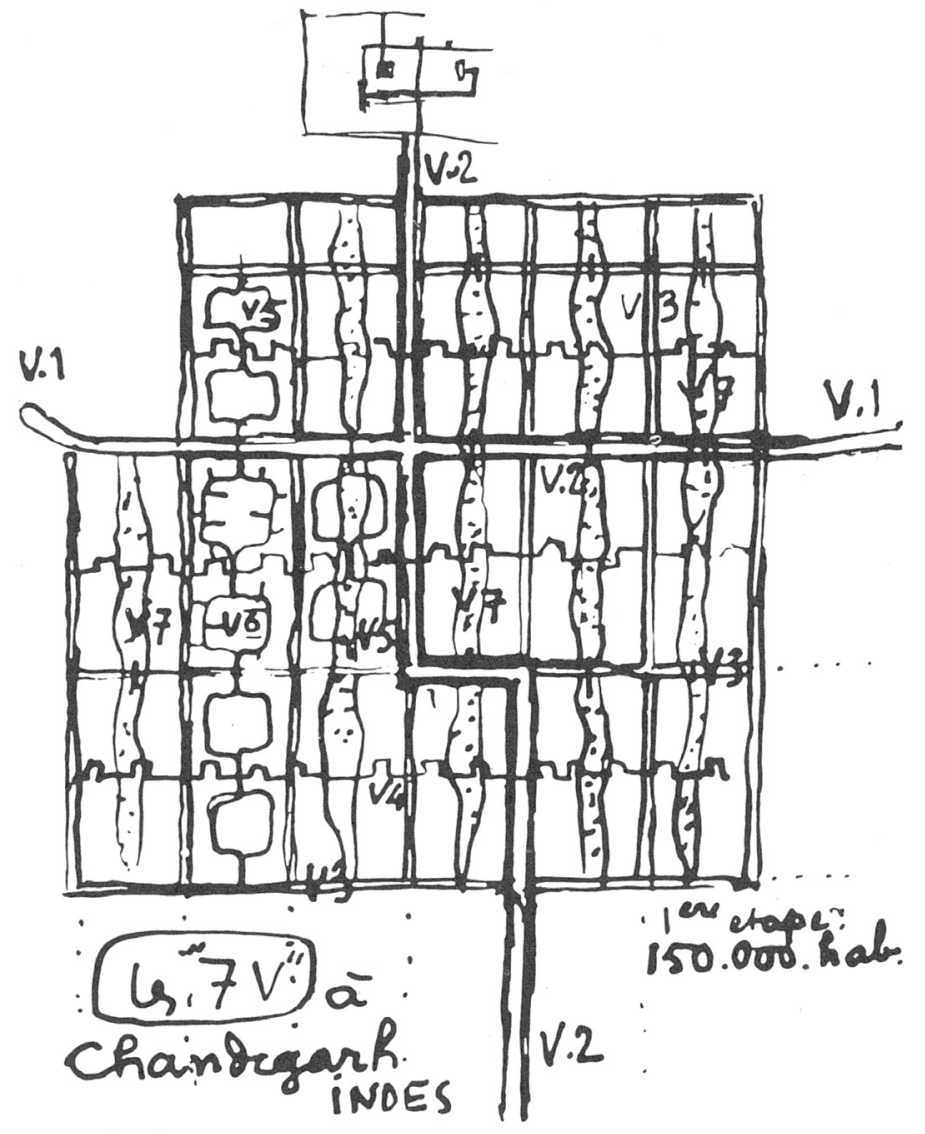

Figura 93: Projeto para Chandigarh - Le Corbusier, 1951 hierarquia viária

Fonte: BENEVOLO, 2009, 705 


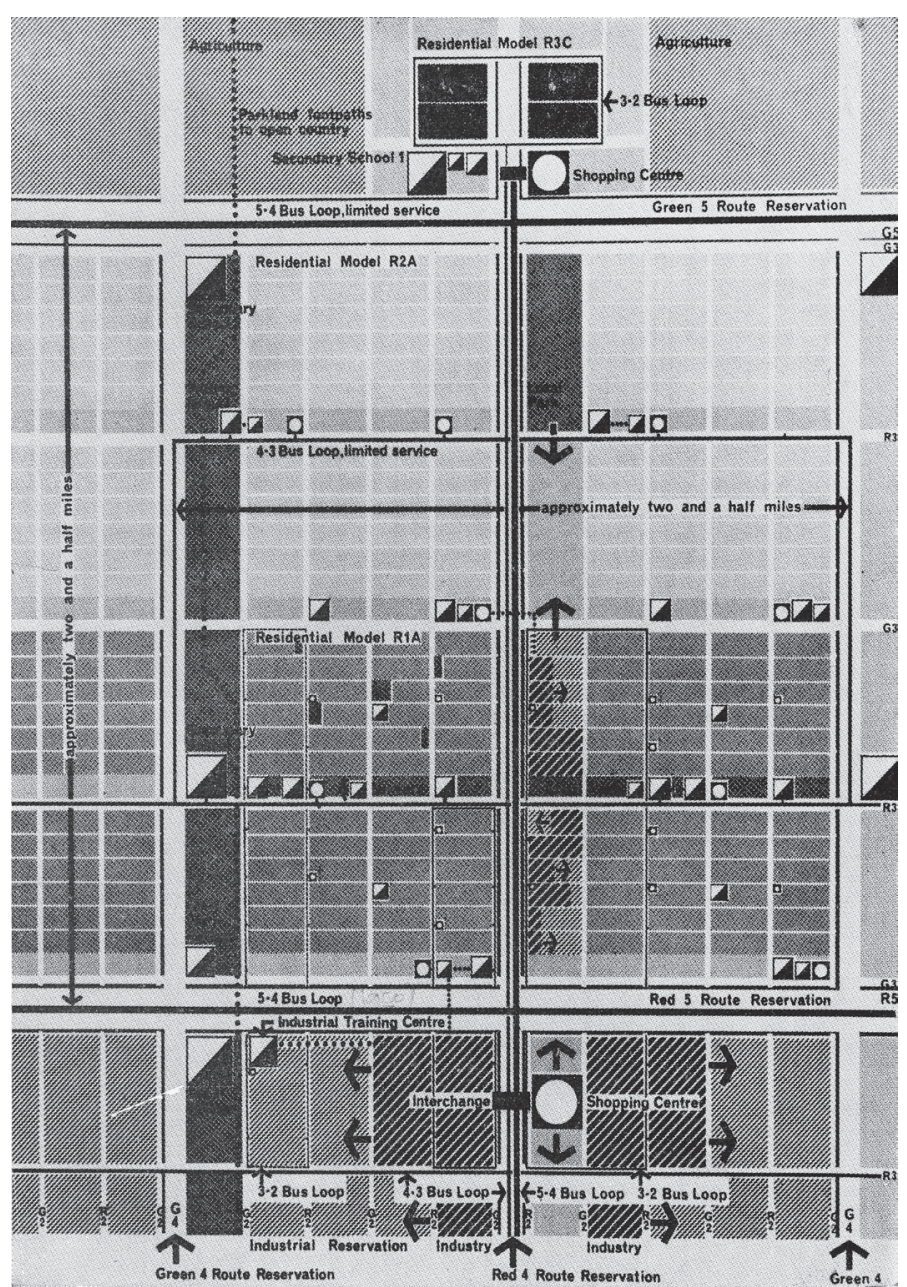

Figura 94: South Hampshire Study, Colin Buchanan\&Partners, 1966 - unidade básica de planejamento

Fonte: COLIN BUCHANAN \& PARTNERS, 1966: 116*

*Esta figura não apresenta legenda tanto no relatório do Estudo quanto no texto publicado em 1970 estenderiam para dentro da trama e estariam vinculadas a usos habitacionais. Outros equipamentos ainda estariam situados nas vias de nível 3 - vermelhas, entre eles escolas e comércios locais. Esta unidade de planejamento seria delimitada por vias verdes, das classes 5 e 4, destinadas a abrigar exclusivamente a circulação motorizada.

A unidade de planejamento organizava também densidades populacionais diferenciadas. As áreas habitacionais "modelo R1A", consideradas de média densidade, abrigariam coeficientes de $45 \mathrm{hab} / \mathrm{ha}$ e estariam situadas mais próximas ao principal eixo de atividades, as vias 5 - vermelhas. O "modelo R2A" teria densidades menores, da ordem de 15 hab/ha e, finalmente, o "modelo R3A", abrigaria as maiores densidades, de 150 hab/ha, mas curiosamente situava-se bastante afastado do principal eixo de atividades, no limite extremo da área de urbanização. Estas previsões de adensamento estariam ainda vinculadas à simulações de crescimento populacional, contabilizando crescimento vegetativo e migração esperada, para os horizontes de 1981, 1991 e 2001.

A agregação destas unidades de planejamento constituiria, por fim, o suporte para a urbanização da área chamada como corridor em South Hampshire. Por meio deste raciocínio eram permitidas possibilidades de replicação quase indefinidas. Neste caso, eram somente os ditames do sítio topográfico que ditavam a direção leste-oeste, mas, ao que parece, outras configurações de terreno poderiam facilmente se enquadrar neste mesmo conceito.

Neste sentido, o Estudo para South Hampshire dava claras indicações da nova escala da urbanização na era da difusão dos transportes motorizados sobre pneus: a escala regional:

"The structure is not fixed or static in its size. This was a basic factor in our whole approach to the study of the growth of urban structure, that it should be a structure capable of growth in the future and should never be seen as a complete unit. This structure allows growth in many directions; it can be applied on many scales, from a town to a whole region.” (COLIN BUCHANAN \& PARTNERS, 1966: 103) 
Frente a necessidade de abrigar o intenso crescimento demográfico esperado, a opção de Colin Buchanan e sua equipe não era por uma política de adensamento das duas cidades existentes, mas sim pela ocupação de uma nova área entre elas, com aproxima-

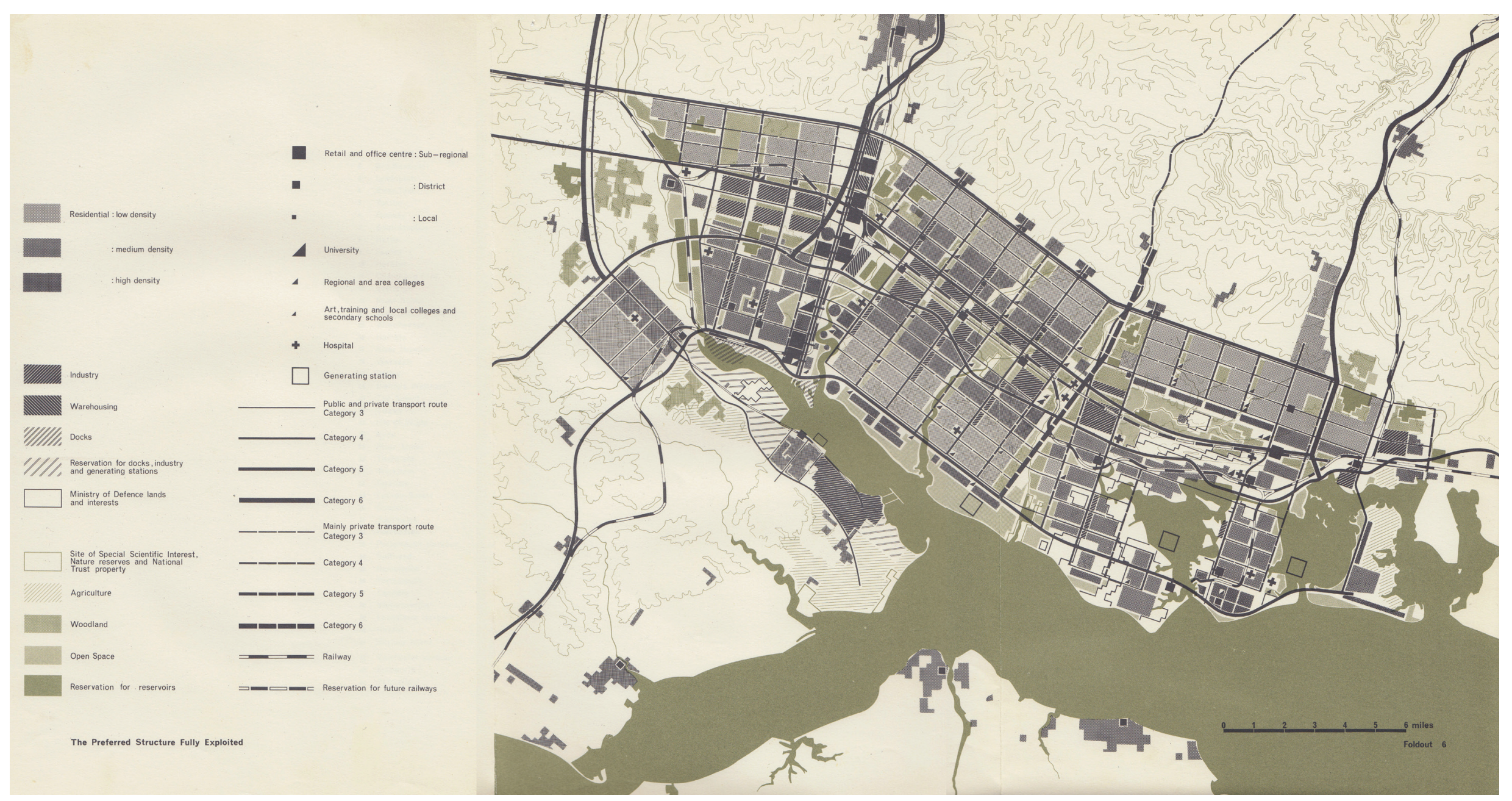

Figura 95: South Hampshire Study, Colin Buchanan\&Partners, 1966 - estrutura urbana plenamente explorada para South Hampshire em 2001 Fonte: COLIN BUCHANAN \& PARTNERS, 1966: fig.6 
damente $20 \mathrm{~km}$ de extensão.

Não por acaso, este mesmo raciocínio seria aplicado novamente por ocasião do estudo intitulado "Kuwait: National Physical Plan and Master Plan for Urban Areas", de 1970. A proposta de Colin Buchanan desmontava a estrutura radio concêntrica do plano de 1957 e previa a criação de uma trama direcional. A dimensão regional da urbanização assumia neste caso a organização de todo o território, propondo a criação de vias regionais com mais de $40 \mathrm{~km}$ de extensão, que amarravam núcleos de urbanização antes desconectados da capital.
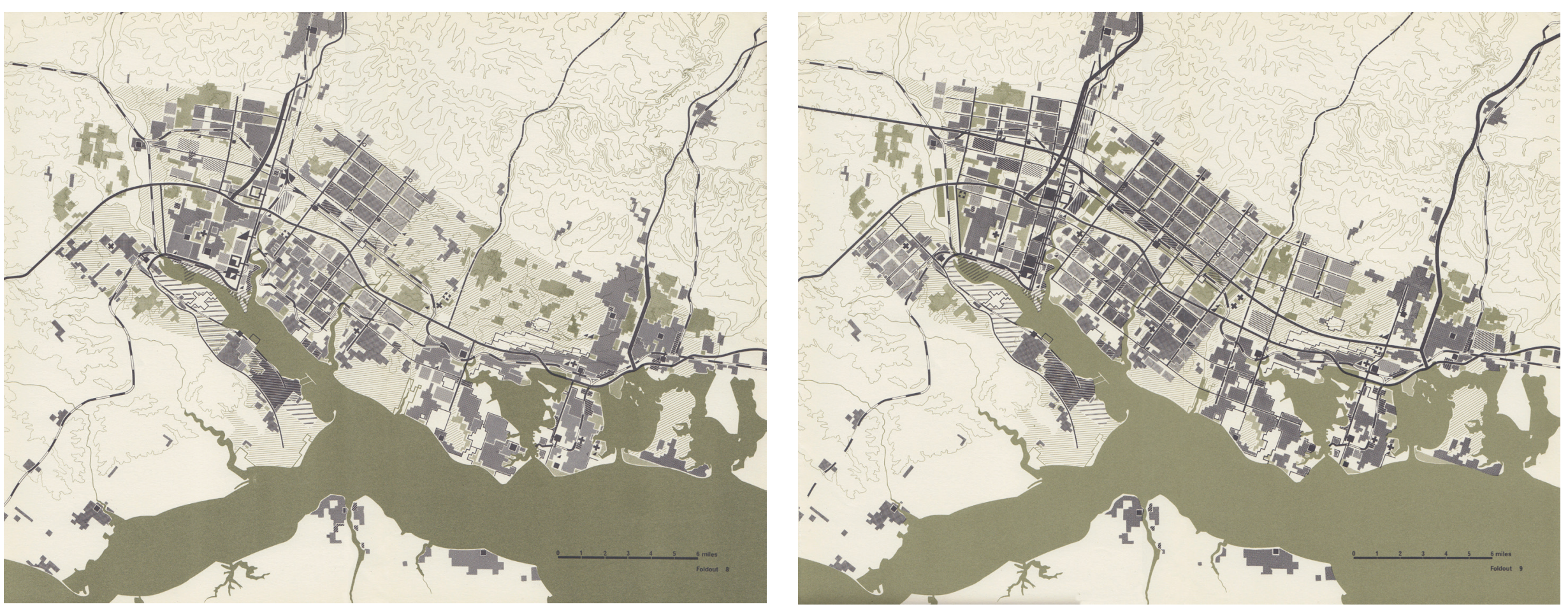

Figura 96: South Hampshire Study, Colin Buchanan\&Partners, 1966 - etapas parciais de ocupação em 1981 e 1991 Fonte: COLIN BUCHANAN \& PARTNERS, 1966: fig.8 e 9 


\section{A trama direcional e a tensão entre modos públicos e privados}

Embora o Estudo para South Hampshire indicasse a trama direcional como um desdobramento da estrutura linear, acreditamos que a escolha apresentada expressava muito mais uma tensão que uma decisão segura sobre a estrutura urbana considerada mais adequada, de acordo com os critérios estabelecidos pelo Estudo. A sua própria denominação - trama direcional - já denunciava uma posição intermediária entre a estrutura em trama e a linear.

Como estrutura urbana, o arranjo linear sugere a associação dos usos do solo a um eixo estruturante de transporte, concentrando atividades ao longo de um sistema de média ou grande capacidade. Em geral, a ferrovia vinha sendo o modo mais relacionado a este tipo de estrutura nas investigações urbanas desde Arturo Soria y Mata, no final do século XIX, até o estudo desenvolvido pelo grupo MARS nos anos 1930. A trama, ao contrário, pareceu sempre mais associada à dispersão dos deslocamentos e por isso muito adequada ao transporte individual motorizado. A comparação entre a trama e a configuração radio-concêntrica, elaborada por Doxiadis (1968) e mencionada anteriormente, deixava clara a vinculação da primeira à flexibilidade exigida pelos novos assentamentos e, portanto, seu melhor desempenho em relação aos automóveis.

A configuração final da área do corridor, proposta pelo Estudo, associava características das estruturas lineares, ao vincular o processo de expansão urbana às vias 5 - vermelhas, e também da trama, sobretudo nas unidades de planejamento. Neste sentido, a trama direcional, adotada por Colin Buchanan para South Hampshire, era a expressão de uma tensão entre os modos públicos e privados.

Ao contrário de seu trabalho mais conhecido - Traffic in Towns - a atividade de Colin Buchanan como consultor a partir de 1964 vinha, ao que parece, assimilando a questão dos transportes coletivos. Seus trabalhos para Bath (1965) e Cardiff (1966), por exemplo, continham análises e propostas consistentes para modos coletivos de deslocamento urbano. No plano para Bath propôs a circulação de ônibus em vias fechadas para o

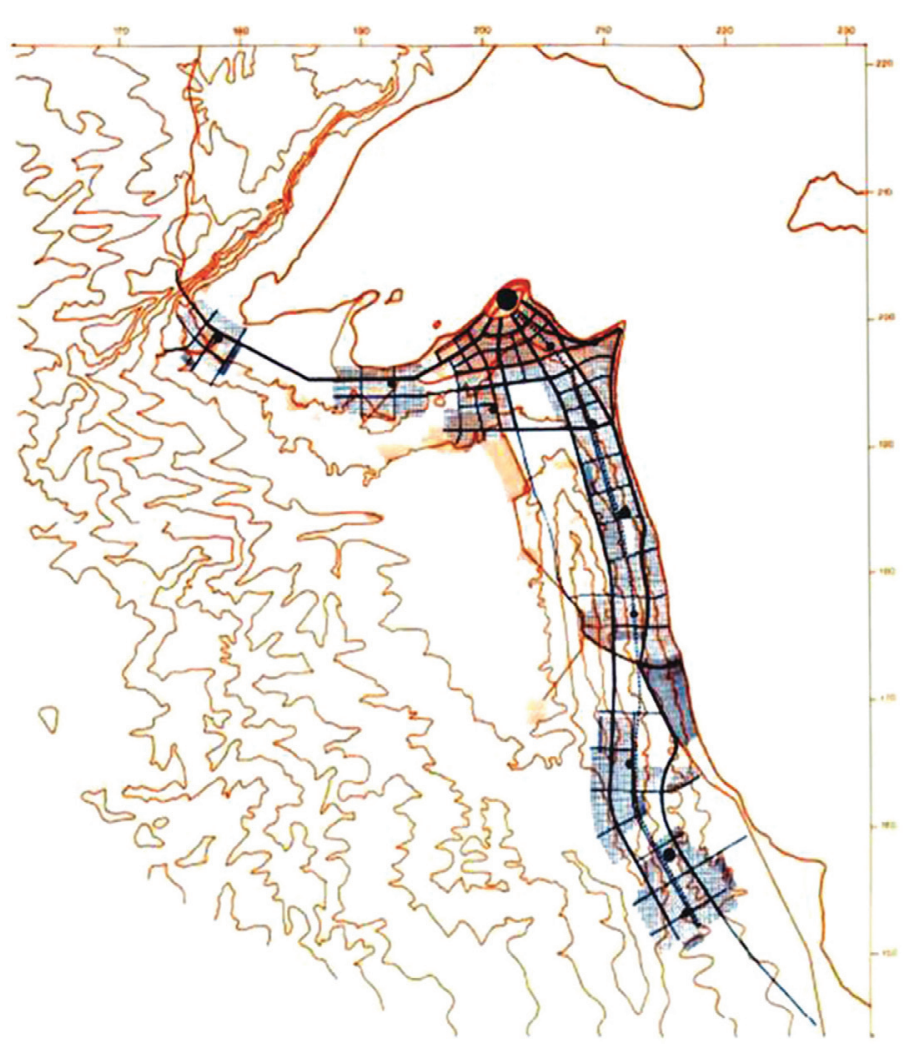

\section{PREFERRED URBAN STRATEGY}

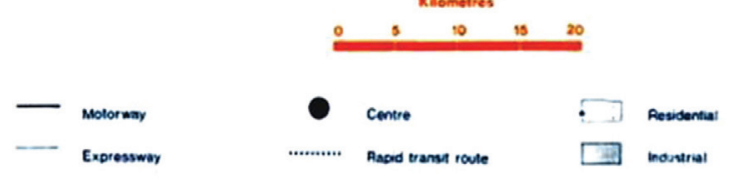

Figura 97: Kuwait: National Physical Plan and Master Plan for Urban Areas, Colin Buchanan\&Partners, 1970 - estratégia urbana escolhida

Fonte: COLIN BUCHANAN \& PARTNERS, 1970: 140 


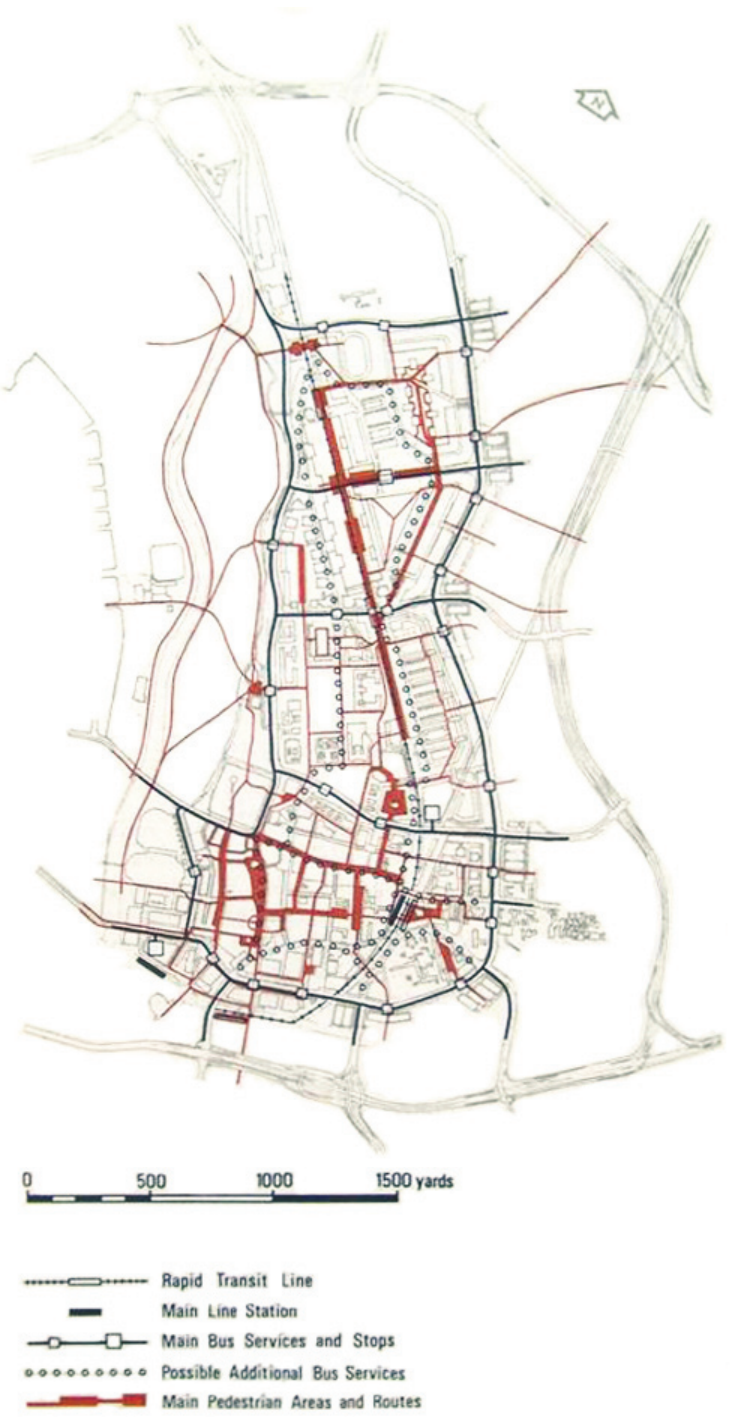

Figura 98: Estudo para Cardiff - circulação de pedestres e transporte público Fonte: COLIN BUCHANAN\&PARTNERS, 1966: fig 33 tráfego de automóveis. Em Cardiff a proposta previa modos sobre pneus e trilhos e associava o sistema de transportes a circuitos de pedestres, como uma estratégia de fortalecimento da área central daquela cidade.

No entanto, no Estudo para South Hampshire, contemporâneo aos trabalhos para Bath e Cardiff, a incorporação dos transportes públicos se apresentava ainda como algo um tanto quanto incerto. Em outras palavras, o papel dos modos públicos parecia ainda carente de maior força. Ao que parece, Colin Buchanan ainda tinha dúvidas sobre a capacidade da estrutura proposta de garantir boas condições operacionais dos sistemas de transporte:

"It must be stressed that urban structure design and transportation policy should be regarded as one and the same thing and should be evolved together in the light of a common strategy. Nevertheless, although design can influence people to use public transport, it is the efficiency, comfort, convenience and cost of the transport itself which will be the major factors governing its use. The urban structure provides the opportunities - it is for the transport operators to exploit" (COLIN BUCHANAN \& PARTNERS, 1966: 138)

A mesma incerteza não era atribuída ao automóvel na trama direcional; que cumpriria, segundo ele, um importante papel de preservação das condições ambientais das cidades existentes de Southampton e Portsmouth:

"As expansion progresses the demand for movement, especially by private car, will rise sharply. The bulk of the movement, in fact, will undoubtedly be car-based. This could aggravate the already serious problems existing in the two cities. We think that the transport strategy should be aimed at concentrating private car traffic on the new network as far as possible so that at any rate some of the rising 'pressure' is drawn off the older communities.” (COLIN BUCHANAN \& PARTNERS, 1966: 138)

Este posicionamento incerto se expressava nas propostas do Estudo. Assim, embora vinculado à ferrovia existente, o principal eixo de desenvolvimento do corridor não a apro- 
priava de fato como sistema urbano. A distância entre estações, previstas entre $3 \mathrm{~km}$ e 4 $\mathrm{km}$, não as caracterizavam com o perfil urbano necessário, ainda que estivem associadas aos centros locais. Nesta condição, sua utilização dependeria de sistemas alimentadores, como de fato ocorria, mas comprometia definitivamente seu papel como meio urbano de deslocamento. Esta situação fazia da ferrovia um sistema regional de transporte.

Neste sentido, Colin Buchanan permanecia fiel ao seu descrétido em relação aos modos sobre trilhos, que vinha se firmando desde Mixed Blessing. No texto do Estudo, não por acaso, descartou a transformação da ferrovia em um sistema metroviário.

Foi em relação ao sistema público sobre pneus que o Estudo mais avançou. No detalhamento da unidade de planejamento, comentado anteriormente, o transporte por ônibus apareceu proposto como serviço expresso, ao longo das vias 5 - verdes, e parador, ao longo do eixo principal, as vias 5 - vermelhas, tratadas como eixos de atividades. Além disso, estava prevista também a conexão transversal do corridor, partindo das áreas habitacionais de maior densidade, passando pelos centros regionais e chegando à faixa da orla marítima. Por fim, o serviço de ônibus contaria ainda com atendimentos na área habitacional interna da trama.

No entanto, as densidades populacionais previstas e a configuração dos usos conduziam a proposta para uma configuração muito mais adequada aos automóveis. Ao contrário do que se poderia esperar, as áreas habitacionais próximas ao eixo principal de atividades (modelo R1A), onde se esperariam maiores adensamentos, contavam com previsões modestas de $45 \mathrm{hab} / \mathrm{ha}$. As maiores densidades estariam justamente no extremo da área urbanizada, localizadas numa situação de transição entre o meio urbano e o rural. No seu conjunto, as previsões do Estudo, davam conta de uma densidade bruta da ordem de 38 hab/ha, o que se configurava bastante desfavorável aos modos públicos de transporte.

Ao mesmo tempo, a previsão de áreas industriais ao longo da ferrovia, junto ao eixo principal de atividades, separava a área urbana proposta em duas partes. Esta opção comprometia a configuração de uma centralidade mais forte ao longo do eixo da via 
5 - vermelha, mas sobretudo limitava a integração entre os dois lados do eixo do ponto de vista dos pedestres. Ou seja, novamente privilegiavam-se os automóveis.

Ainda que fiel ao automóvel, este movimento em relação aos transportes públicos não deixava de ser instigante. A atuação de Colin Buchanan como consultor coincidiu justamente com a alternância de poder, promovida pela maioria Trabalhista no Parlamento Britânico e a conseqüente mudança de rumos na política de transportes, com maior ênfase nos modos públicos e uma política de restrição ao uso dos automóveis.

O momento do Estudo para South Hampshire parece assim uma forma de realinhamento às novas exigências, manifestando tensões e questões ainda não plenamente resolvidas por Colin Buchanan. Mesmo sem abandonar sua aposta no automóvel, ele parecia definitivamente reconhecer seus limites e incorporar em seus trabalhos sua necessária associação com os modos públicos. 


\section{conclusão}

Neste trabalho, procuramos construir um entendimento da questão da mobilidade urbana a partir da obra de Colin Buchanan. Embora seu discurso tenha se concentrado basicamente na relação entre automóvel e cidade, acreditamos que a forma de aproximação teórica e projetual construída por ele implicou na configuração de um importante referencial para o tratamento das questões de circulação urbana, em um período de expansão significativa da frota de automóveis e de acirramento dos problemas urbanos relacionados à mobilidade.

Inicialmente buscamos situar Colin Buchanan no contexto de sua época. Por essa razão recuperamos sua trajetória profissional e a repercussão de sua obra. Posteriormente, discutimos também o ambiente teórico e prático do urbanismo e dos transportes nos anos 1950 e 1960, período no qual estão inseridos seus trabalhos.

A análise da trajetória profissional de Buchanan revelou a consciência e a intencionalidade de um caminho construído a partir da busca pela articulação entre planejamento urbano e transportes, desde os primeiros momentos de sua carreira. Os anos 1960 destacam-se como momento de maior notoriedade para Colin Buchanan, principalmente a partir da divulgação de Traffic in Towns, por meio do qual suas idéias ganham amplitude internacional, tendo reverberações inclusive no Brasil. 
Em relação ao quadro contextual, abordamos o que consideramos ser as duas principais referências para a construção do discurso de Colin Buchanan. De um lado, o debate urbanístico do período mostrava como a questão da mobilidade esteve presente e havia gerado resultados que já vinham sendo objeto de análises e avaliações críticas. Neste sentido, o programa britânico de construção de novas cidades parece ter sido um momento particular de proposição, implementação e avaliação da produção de cidades no pós-guerra, como ressaltou Benevolo (2009).

De outro lado, destacamos a vertente norte-americana da engenharia de tráfego como outro referencial importante para Colin Buchanan. Neste caso, interessa observar como o engenheiro-urbanista britânico estabelece um contraponto a esta corrente de pensamento, afirmando as demandas urbanas como indispensáveis à elaboração de planos e projetos de circulação. Como alerta Vasconcelllos (1999), Buchanan redireciona o foco da questão da circulação urbana: de um conflito entre fluidez e segurança, como propunham seus colegas norte-americanos, para uma tensão entre cidade e tráfego.

Para Colin Buchanan havia um conflito entre cidade e tráfego, caracterizado por uma tensão permanente entre accessibility e environment. Assim, os problemas da circulação urbana observados nos anos 1960, especialmente o congestionamento de tráfego, exigiam uma nova abordagem conceitual capaz de abarcar as interfaces urbanas das diferentes dinâmicas de movimentos. Procuramos mostrar em nosso trabalho como Buchanan montou um discurso que se tornou notável pela ênfase nas questões relativas à cidade e suas demandas. Desta forma, o engenheiro-urbanista britânico definiu um caminho diverso daquele que tendia a se concentrar nas soluções restritas à dinâmica do movimento, como fazia a engenharia de tráfego.

Diante deste panorama, procuramos discutir a mobilidade urbana tendo como foco a escala da cidade, utilizando a obra de Colin Buchanan como subsídio. Neste sentido, propomos que as questões urbanas presentes em sua obra se desdobram em quatro aspectos relevantes; chamados de dimensões em nosso trabalho: 1) a mobilidade urbana como uma questão política; 2) o fenômeno da circulação urbana; 3) a escala urbana 
local; 4) a estrutura urbana e regional para o tráfego.

Discutindo a primeira das dimensões, destacamos como Colin Buchanan formulou a questão da circulação urbana como problema situado na esfera política, assumindo assim a cidade como lugar do embate entre diferentes pensamentos. Neste movimento, o engenheiro-urbanista marcou uma diferença fundamental em relação às correntes que localizavam o planejamento na esfera da técnica e, portanto, distante dos arranjos conjunturais das forças sociais. Ao mesmo tempo, ao construir um discurso comprometido com a defesa do automóvel, ele mesmo assumia uma posição política no cenário da mobilidade urbana dos anos 1960. Neste aspecto, procuramos mostrar como este posicionamento esteve bastante alinhado ao poderoso setor econômico ligado à indústria automobilística da época.

Associado a esse reconhecimento da cidade como palco de escolhas políticas, Colin Buchanan defendeu a constituição de uma forma diferente de tratamento das questões de circulação por parte do Estado, mais adequada ao novo cenário de crescimento do papel dos automóveis.

Na segunda das dimensões abordadas, procuramos mostrar que a aposta no automóvel como modo de circulação urbana exigiu de Buchanan um esforço para a compreensão do tráfego como fenômeno urbano, sua natureza e suas formas de ocorrência. Em outras palavras, nesta dimensão, o engenheiro-urbanista busca dar maiores contornos a um dos elementos da polaridade proposta por ele: aquilo que chamou de accessibility.

Há no discurso de Colin Buchanan um notável esforço de construir categorias de análise que pudessem dar suporte ao estabelecimento de critérios para permissão ou restrição do tráfego. Neste sentido, distinguir entre tráfego essencial e opcional era uma forma de se estabelecer um parâmetro para capacidade de assimilação do tráfego dentro de áreas urbanas constituídas. Em outras palavras, sua aposta no automóvel como modo de transporte, não significou assumir a defesa intransigente de sua presença em todos os locais da cidade. 
Em seguida, vimos como a partir deste conceito Buchanan discute as questões do tráfego de passagem e das áreas centrais. No primeiro caso, tratava-se da tentativa de desmontar os argumentos utilizados em defesa de uma solução comum, empregada pelo planejamento urbano da época para os problemas causados pelo tráfego: as vias perimetrais. Buchanan pretendia mostrar que, antes de tudo, o congestionamento era um problema com origem urbana. As viagens dispersas eram, segundo ele, as principais responsáveis pelo congestionamento e estavam fortemente associadas à utilização dos automóveis como modo de transporte. Neste sentido, o conceito de vias perimetrais estaria em franco desacordo com o que de fato se observava nas cidades.

Buscamos mostrar também como a compreensão do fenômeno da circulação urbana passava pela análise dos problemas de congestionamento de tráfego nas áreas centrais. Esta era uma questão particularmente sensível para Buchanan, na medida em que viabilizar a presença dos automóveis nestas áreas era considerado um passo fundamental para permitir a tão desejada convivência entre cidade e tráfego. Eram também nas áreas centrais onde as demandas conflitantes de veículos, pedestres e usos do solo mais de intensificavam.

A terceira das dimensões urbanas da obra de Colin Buchanan se concentra na escala urbana da convivência, onde os pedestres e as demandas externas à circulação teriam predominância. Em outras palavras, tratava-se das demandas ambientais da polaridade entre environment e accessibility. Analisamos esta dimensão em duas escalas: da vizinhança e da rua.

$\mathrm{Na}$ escala da vizinhança, Colin Buchanan se empenhou em estabelecer padrões ambientais que determinassem um limite de capacidade para assimilação do tráfego de automóveis. Neste sentido, pretendemos mostrar como o engenheiro-urbanista sintetizou estas demandas no conceito de environmental areas. Esta noção trazia em consideração padrões ambientais, formulados por ocaisão de Traffic in Towns, particularmente baseados na poluição sonora e sua relação com o volume de tráfego. Também assimiliva as demandas de pedestres e sua relação com atividades comerciais. Nesse sentido, as envi- 
ronmental areas eram definidas por Buchanan como os cômodos em uma casa, à medida que se pautavam pela noção de ambientes associados a padrões ambientais definidos.

Aqui, Buchanan estabelecia um contraponto com as análises econômicas, que vinham se firmando como instrumentos importantes de avaliação de intervenções no cenário de transportes nos anos 1960. Buchanan entendia que alguns impactos gerados a partir da construção de uma via não poderiam ser mensurados em preços, como pressupunha a metodologia de custos/benefício.

Cada setor da cidade, segundo Colin Buchanan apresentaria uma capacidade de absorver volumes veiculares. Este dado, intrínseco a cada vizinhança e chamado de capacidade ambiental, seria um dos principais elementos para definição das environmental areas.

Em nossa tese, procuramos discutir como a aplicação deste conceito se mostrava ainda bastante imprecisa. Utilizamos o exemplo de Cardiff: Development and Transport Study para discutir os critérios empregados na delimitação das environmental areas e verificamos que a noção lançada por Buchanan ainda era embrionária e deveria ser entendida como algo passível de desenvolvimentos futuros.

Posteriormente, procuramos discutir a resolução do conflito entre cidade e tráfego na escala da rua. Destacamos que as soluções divulgadas por Buchanan estabeleciam um forte diálogo com a emergente área do projeto urbano e se relacionavam com obras como as de Louis Kahn e do Casal Smithson. Com este discurso, Colin Buchanan incorporava outras demandas aos critérios de desempenho utilizados em projetos viários. Propunha, neste sentido, a noção de Traffic Architecture.

Na quarta das dimensões propostas neste trabalho, procuramos mostrar como o Estudo para South Hampshire sintetizou as preocupações de Colin Buchanan em relação às escalas da cidade e da região. Nesta ocasião também a oposição entre accessibility e environment foi reproposta e trabalhada em termos de uma estrutura urbana adequada à cidade na era dos automóveis, que reconciliava a oposição mencionada. 
Neste sentido, Colin Buchanan construiu um interessante debate com diferentes correntes do urbanismo, analisando três estruturas urbanas consideradas elementares. Sua conclusão é reveladora do discurso que construiu no período analisado neste trabalho: a trama direcional era a mais adequada à cidade na era do automóvel, uma vez que atendia plenamente à demanda da flexibilidade, considerada naquele momento uma qualidade positiva dos planos urbanísticos, mas também uma característica do automóvel como modo de transporte.

Por meio desta estrutura era possível admitir expansões quase sem limites para os assentamentos. Não por acaso, no Estudo para South Hampshire Buchanan propôs aquilo que seria uma unidade básica de planejamento, que teria a capacidade de se replicar quase indefinidamente. Assim, a escala regional, outro fator fortemente ligado ao transporte individual motorizado, era também contemplada.

Procuramos mostrar ainda como este momento de síntese da obra de Colin Buchanan esteve acompanhado de um importante tensionamento. De fato, o Estudo para South Hampshire expressou também a fragilidade de sua aposta nos automóveis, diante de uma nova configuração do setor de transportes. Neste sentido, procuramos evidenciar como o Estudo se esforçou em incorporar uma maior atenção às demandas de transportes públicos.

Este movimento de Colin Buchanan em relação aos transportes públicos, ainda que controverso, não deixa de ser instigante. Já em Traffic in Towns, havia indicado alguns limites para o uso dos modos privados motorizados. Para ele, o automóvel não atenderia sozinho a todas as demandas, mas era preciso associá-lo aos transportes públicos (BUCHANAN, 1963). Apesar disso, naquele momento o texto do Relatório não avançou neste sentido, talvez por conta de sua demanda objetiva: o estudo do impacto do crescimento dos veículos particulares.

Embora tenha deixado clara a sua confiança no automóvel como modo de deslocamento urbano, o transporte público passou a figurar entre as considerações de seus planos e 
estudos como consultor. Não foi possível determinar neste trabalho até que ponto seu movimento em direção aos transportes públicos, sobretudo sobre pneus, resultou de uma demanda apresentada pelas próprias cidades que o contrataram como consultor ou de uma reavaliação elaborada pelo próprio Buchanan. No entanto, chama atenção seu alinhamento com as novas perspectivas da política pública de transportes com o novo governo do Partido Trabalhista.

Ao recuperar o discurso construído por Colin Buchanan entre 1958 e 1966, procuramos demonstrar como o engenheiro-urbanista britânico construiu uma aproximação particular da questão da mobilidade urbana. Em um momento de separação das diversas áreas do planejamento e do projeto, Colin Buchanan propôs uma forma de abordagem caracterizada pela visão abrangente do problema da circulação urbana. Ainda que sua aposta intransigente no automóvel como modo privilegiado de transporte urbano, nos pareça hoje indefensável, interessa destacar a vitalidade de sua análise da relação entre cidade e os modos de deslocamento.

Ao considerarmos a situação brasileira no campo da mobilidade urbana, na qual o automóvel é, sem dúvida, peça chave, acreditamos que a forma de abordagem que Colin Buchanan construiu ao longo destes anos pode nos indicar caminhos promissores para o tratamento das questões urbanas nos planos, projetos e obras de transportes, que vêm sendo demandados nos últimos anos. 


\section{bibliografia}

\section{Livros e artigos}

AMERICAN ASSOCIATION OF STATE HIGHWAY ANDTRANSPORTATION OFFICIALS (AASHTO). A Policy on Geometric Design of Highways and Streets: 1994. Washington, DC: AASHTO, 1995.

AMERICAN ASSOCIATION OF STATE HIGHWAY OFFICIALS (AASHO). A Policy on arterial highways in urban areas. Washington, DC: General Offices, 1965 (1957)

ANELLI, R. L. S; SEIXAS, A. R.. O peso das decisões: o impacto das redes de infra-estrutura no tecido urbano. In: ARTIGAS, Rosa Camargo (org). Minhocão: memória, idéias e projetos. São Paulo: Prefeitura Municipal de São Paulo/SEMPLA, 2008, pp. 59-73.

ANELLI, Renato. A cidade contemporânea: uma conversa com Joaquim Guedes. São Paulo, Revista Eletrônica Arqtextos 099_02, agosto de 2008.

ANELLI, Renato. Calçadões paulistanos: em debate o futuro das áreas de pedestres do centro de São Paulo. São Paulo, Revista Eletrônica Arqtextos 60, maio de 2005.

ANELLI, Renato. Redes de Mobilidade e Urbanismo em São Paulo: das radiais/perimetrais do Plano de Avenidas à malha direcional PUB. Revista Eletrônica Arqtextos 82. São Paulo, Portal Vitruvius, março de 2007. Disponível em: < http://www.vitruvius.com.br/arquitextos/ arq082/arq082_00.asp>. Acesso em: 18 jul. 2009.

ANELLI, Renato. Redes de Mobilidade e Urbanismo em São Paulo: das radiais/perimetrais do Plano de Avenidas à malha direcional PUB. São Paulo, Revista Eletrônica Arqtextos 082, março de 2007. 
ANELLI, Renato. Urbanização em rede: os Corredores de Atividades Múltiplas do PUB e os projetos de reurbanização da EMURB em São Paulo (1972-82). São Paulo, Revista Eletrônica Arqtextos 088_01, setembro de 2007.

APPLEYARD, D.; LYNCH, K. MYER, J. The view form the road. Massachusetts, MIT Press, 1963

ARMSTRONG, John. Planning and public transport. Town and Country Planning Review, vol XXVI, $\mathrm{n}^{\circ} 4$, abril 1958, pp. 164-167.

AUCOTT, Joan V. Planning and the motor vehicle. Town and Country Planning Review, vol XXVIII, n¹2, dezembro 1960, pp. 403-417.

BANHAM, Reyner. Megaestructuras: futuro urbano del pasado reciente. Barcelona, Gustavo Gilli, 1978 (1976).

BARKER, T. C.; ROBBINS, M. A history of London transport. London, George Allen \& Unwin Lts, 1974. Volume II: The twentieth century to 1970.

BARONE, Ana Cláudia Castillo. Team 10: arquitetura como crítica. São Paulo, Annablume FAPESP, 2002.

BEESLEY, M. E.; KAIN, J. F. Forma urbana, motorización y política pública de actuación: una valoración sobre "Traffic in Towns". In: AAVV. Las incognitas del trafico urbano. Barcelona, Editorial Gustavo Gili S/A, 1968.

BENEVOLO, Leonardo. História da cidade. São Paulo, Ed. Perspectiva, 2009.

BENEVOLO, Leonardo. O ultimo capítulo da arquitectura moderna. Lisboa - Portugal, Edições 70 Lda, 2009a (1985)

BENEVOLO, Leonardo. The origins of Modern Town Planning. Massachusetts, MIT Press - Paperback Edition, 1971 (1963)

BENEVOLO; MELOGRANI; LONGO. Projectar a cidade moderna. São Paulo/Lisboa, Ed. Martins Fontes/Ed. Presença, 1977 (1966)

BERMAN, Marshall. Tudo que é sólido desmancha no ar: a aventura da modernidade. São Paulo, Cia das Letras, 2007 (1982)

BILL, Geoffrey. Oxford traffic. Town and Country Planning Review, vol XXIII, n¹39, novembro 1955, pp. 529-531.

BOAGA, Giorgio. Diseño de tráfico y forma urbana. Barcelona, Gustavo Gili, 1977. 
BRUEGMANN, Robert. Sprawl: a compact history. Chicago e Londres, The University of Chicago Press, 2005.

BUCHANAN, Colin. I told you so. London, mimeo, 2002.

BUCHANAN, Colin. Mixed Blessing: the motor in Britain. London, Leonard Hill Ltda., 1958.

BUCHANAN, Colin. The Stansted Controversy: no way to the airport. Harlow, Longman, 1981.

BUCHANAN, Colin. The state of Britain. London, Faber \& Faber, 1972.

BUCHANAN, Colin. Tráfego nas cidades. Engenharia Municipal, n³1, abr-jun de 1967, pp 7-19 (Tradução da conferência proferida no Instituto de Engenharia no dia 10 de novembro de 1966)

BUCHANAN, Colin. Traffic in Towns: a study of the long term problems of traffic in urban areas. London, Her Majesty's Stationery Office, 1963.

BUCHANAN, Colin. Traffic in Towns: the critics answered. Traffic Engineering and Control, $\mathrm{n}^{\circ} 1$, vol 6, maio 1964, pp. 39-42.

BUCHANAN, Colin. Traffic in Towns: the specially shortened edition of the Buchanan Report. Harmondsworth (UK), Penguin Books Ltd, 1964a.

BUCHANAN, Malcolm. The end of Traffic in Towns? Londres, mimeo, 2001.

CHOAY, Françoise. O urbanismo. São Paulo, Ed. Perspectiva, 2003 (1965)

COLIN BUCHANAN \& PARTNERS. Estudio de Hampshire Sur. In: LEWIS, David (org). La ciudad: problemas de diseño y estructura, Barcelona, Gustavo Gili, 1970.

COLLINS, George R. The linear city. In: LEWIS, David (ed). The pedestrian in the city. Letchworth, UK, The Garden City Press Ltda, 1966.

CULLEN, Gordon. Paisagem Urbana. Lisboa - Portugal, Edições 70 Lda, 2009 (1961).

CULLINGWORTH, B.; NADIN, Vt. Town and Country Planning in the UK. London, Routledge, 2006 (1964).

DAY, Allan. The Transport Act and planning. Town and Country Planning Review, vol XXX, $\mathrm{n}^{\circ} 11$, novembro 1962, pp. 4483-450.

DAY, J. The story of London underground. London, Staples Printers, 1979 (1963).

DEÁK, Csaba. À busca de categorias da produção do espaço. São Paulo, Memorial Crítico/Concurso de Livre Docência - FAU-USP, 2001. 
DOXIADIS, Constantinos. Ekistics: an introduction to the science of human settlements. London, Hutchinson \& Co, 1968.

DOXIADIS, Constantinos. Sobre las ciudades lineales. In LEWIS, David. La Ciudad: Problemas de Disenõ y Estructura, Barcelona, Ed. Gustavo Gili, 1970.

DUPREE, Harry. Urban transportation: the new towns solutions. England \& USA, Gower House, 1987.

DYCKMAN, J. W.. El transporte en las ciudades. In: AAVV. Las incognitas del trafico urbano. Barcelona, Editorial Gustavo Gili S/A, 1968.

ELLEN, E. R. Design for buses: the operator's view. Town and Country Planning Review, volXXXV. $\mathrm{n}^{\circ} 1$, janeiro 1967, pp. 16-18.

ELLIS, Willian C. La estructura especial de las calles. In: ANDERSON, Stanford (ed.). Calles: problemas de estructura y disenõ. Barcelona, Editorial Gustavo Gili S/A, 1981 (1978).

FALUDI, A. Planning Theory. Oxford, Pergamon Press, 1973.

FELDMAN, Sarah. Planejamento e Zoneamento. São Paulo: 1947-1972, São Paulo, Edusp/Fapesp, 2005.

GALATAY, Ervin Y. Neuvas ciudades: de la antiguedad a nuestros días. Barcelona, Gustavo Gili, 1977 (1975)

GIBBERD, F. Town Design. London, The Architectural Press, 1959 (1953)

GIEDION, Sigfried. Espaço, tempo e arquitetura: o desenvolvimento de uma nova tradição. São Paulo, Martins Fontes, 2004 (1941)

GNOATO, Luiz Salvador. Curitiba, cidade do amanhã: 40 depois. Algumas premissas teóricas do Plano Wilheim-IPPUC. Revista Eletrônica Arqtextos 72.01. São Paulo, Portal Vitruvius, maio 2006. Disponível em: <www.vitruvius.com.br/arquitextos/arq072/arq072_01.asp>. Acesso em: 18 jul. 2009.

GOITIA, Fernando C. Breve historia del urbanismo. Madri, Alianza Editorial S.A., 1997 (1968)

GRANT, John. The politics of urban transport planning: an analysis of transportation policy formulation in three UK County Boroughs between 1947 and 1974. London, Earth Resources Research Ltd, 1977.

GRUBLER, A. The rise and fall of infrastructures. Darmstadt, Physica-Verlag Heidelberg, 1990 
GUTFREUND, Owen D. Rebuilding New York in the Auto Age - Robert Moses and the Highways. In: BALLON, Hilary; JACKSON, Kenneth T. (ed.) Robert Moses and the Modern City: the transformation of New York. New York: W.W. Norton \& Company, 2007.

HALL, Peter. Cidades do Amanhã: uma história intelectual do planejamento e do projeto no século XX. São Paulo, Ed. Perspectiva, 2007 (1988).

HALL, Peter. The Buchanan report: 40 years on. In: Transport (Institution of Civil Engineers), n. 157, February, 2004, pp. 7-14

HALL, Peter. Urban and Regional Planning. London, Routledge, 2002 (1975).

HALPRIN, L. Freeways. New York, Reinhold Publishing Co., 1966.

HÉNARD, Eugene. Alle origini dell'urbanistiga de la costruzione della metropoli. Padova, Marsilio Editori, 1972.

HODGE, W. Buchanan on holiday. Town and Country Planning Review. vol XXXII. $\mathrm{n}^{\circ} 2$. fevereiro 1964, pp 80-82

HOUGHTON-EVANS, William. Planning cities: legacy and portent. London, Lawrence \& Wishart, 1975.

IHT - INSTITUTION OF HIGHWAYS AND TRANSPORTATION. Roads and Traffic in Urban Area. London, HMSO Books, 1987.

JACOBS, Jane. Do not segregate pedestrians and automobiles. In: LEWIS, David (ed). The pedestrian in the city. Letchworth, UK, The Garden City Press Ltda, 1966.

JACOBS, Jane. Vida e Morte nas Grandes Cidades Americanas. São Paulo-SP: Ed. Martins Fontes, 2001 (1961).

JELLICOE, G. A. Motopia: a study of evolution of urban landscape. Londres, Studio Books, 1961.

KEEBLE, Lewis. Principles and Practice of Town and Country Planning. London, The Estates Gazette Ltd., 1959 (1952)

KENNEDY, D. KENNEDY, M. The inner city. London, Elek Books, 1974.

KENWORTHY, J.; LAUBE, F. An international sourcebook of automobile dependence in cities: 1960-1990. Boulder, Colorado, EUA, University Press of Colorado, 1999.

KOSTOF, Spiro. The city shaped: urban patterns and meanings though history. Londres, Thames \& Hudson, 2006 (1991) 
LAMAS, José M. Ressano Garcia. Morfologia Urbana e Desenho da Cidade, Lisboa-Portugal, Fundação Calouste Gulbekian e Fundação para a Ciência e a Tecnologia, 2000, $2^{\circ}$ ed.

LE CORBUSIER. Os três estabelecimentos humanos. São Paulo, Ed. Perspectiva, 1979 (1943)

LE CORBUSIER. Planejamento Urbano. São Paulo: Ed. Perspectiva, 1971.

LE CORBUSIER. The Athens Charter. New York, Grossman Publishers, 1973 (1943).

LEME, Maria Cristina da Silva. Planejamento em São Paulo: 1930-1969. São Paulo, Dissertação FAU-USP, 1982. (orient. Gilda Bruna)

LEME, Maria Cristina da Silva. ReVisão do Plano de Avenidas: um estudo sobre planejamento urbano em São Paulo, 1930. São Paulo, Tese de FAU-USP, 1990. (orient. Flávio Villaça)

LING, Arthur. Public transport: the Runcorn example. Town and Country Planning Review, vol XXXV, n¹, janeiro 1967, pp. 11-16.

LLEWELYN-DAVIES, Richard. Disenõ de la ciudad. In: LEWIS, David (org). La ciudad: problemas de diseño y estructura, Barcelona, Gustavo Gili, 1970.

LYNCH, Kevin. A imagem da cidade. São Paulo, Martins Fontes, 1997 (1960)

LYNCH, Kevin. A theory of good city form. Cambridge/Londres, MIT Press, 1981.

MADANI-POUR, Ali. The principles of urban design in the British New Towns. Department of Town and Country Planning - University of Newcastle upon Tyne, Working Paper $\mathrm{n}^{\circ} 15$, feb. 1992.

MALTA CAMPOS $\mathrm{F}^{\circ}$, Cândido. O corredor metropolitano como estrutura urbana aberta para a Grande São Paulo. São Paulo, Tese FAU-USP, 1972.

MANNERING, F.; KILARESLI, W. Principles of highway engineering and traffic analysis. New York, John Wiley \& Sons, 1990.

MARSHALL, S. Streets \& Patterns. London e New York, Spon Press, 2005.

MERLIN, Pierre. Newtowns: regional planning and development. Londres, London Methuen \& Co LTD, 1971 (1969)

MEYER, John R. Urban Transportation. In WILSON, James Q. The Metropolitan Enigma, Nova lorque, Anchor Book, 1970 (1968).

MEYER, John R.; GÓMEZ-IBÁNEZ, José A. Autos, transit and cities. Cambridge, Massachusetts/ London, England, Harvard University Press, 1981. 
MINISTRY OF TRANSPORT. Roads in urban areas. London, Her Majesty's Stationery Office, 1966.

MITCHEL, R.; RAPKIN, C. Urban traffic: a function of land use. New York, Columbia University Press, 1954.

MOAK, Lennox. Toll roads and public policy. Town and Country Planning Review. vol XXIV, n 144 , abril 1956, pp. 209-231.

MORLEY, C. D. The future of central retail cores. Town and Country Planning Review. volXXX. n8-9, aug-set 1962, pp. 355-358.

MORRIS, Eleanor Smith. New urban design concepts: greenways and movement structures - the Philadelphia plan. In: LEWIS, David (ed). The pedestrian in the city. Letchworth, UK, The Garden City Press Ltda, 1966.

MOSES, Robert. Programa de melhoramentos públicos para a cidade de São Paulo. PMSP, 1950.

MUMBY, D. L. The influence of transport planning. Town and Country Planning Review. vol XXXII. n 3, março 1964, pp. 149-153.

MUNFORD, Lewis. A cidade na história: suas origens, trnasformações e perspectivas. São Paulo, Ed. Martins Fontes, $4^{\circ}$ Ed., 1998 (1961)

MUNFORD, Lewis. The highway and the city. London, Secker \& Warburg, 1964 (1953)

MUNFORD, Lewis. The urban prospect. London, Secker \& Warburg, 1968 (1956)

NITSCHKE, Gunter. Cities stasis or process. In: LEWIS, David (ed). The pedestrian in the city. Letchworth, UK, The Garden City Press Ltda, 1966.

OSBORN, F. J. Bigger cities or more cities. Town and Country Planning Review, vol XXXI, n8-9, ago-set 1963, pp. 337-343.

OSBORN, F. J. High Density: end of delusion. Town and Country Planning Review, vol XXVII, n5, maio 1959, p. 21.

PAES, Célia Rocha. Roteiro para a discussão da rua a partir de 60. trabalho programado FAU-USP, 1998. (orient. Maria Cristina Leme)

PESSOA, Denise F. Utopia e cidades: proposições. São Paulo, FAPESP/AnnaBlume, 2006.

POTTER, Stephen. Transport and New Towns. Milton Keynes - UK, New Towns Study Unit/Open University, 1976. vol II 
POTTER, Stephen. Transport Planning in the Garden Cities. Milton Keynes - UK, New Towns Study Unit/Open university, $2^{\circ} \mathrm{ed}, 1981$ (1976)

REIS FILHO, Nestor Goulart. Urbanização e Teoria: contribuição ao estudo das perspectivas atuais para o conhecimento dos fenômenos de urbanização. São Paulo, Tese para o Concurso de Cátedra n²2 - FAU-USP, 1967.

RICHARDS, Brian. El Movimiento de las ciudades. In: LEWIS, David (org). La ciudad: problemas de diseño y estructura, Barcelona, Gustavo Gili, 1970.

ROSE, R. W. Scenic routes for motorists. Town and Country Planning Review, volXXXIV, n², fevereiro 1966, pp. 120-123.

SAFDIE, Moshe; KOHN, Wendy. The city after the automobile: an architect's vision. Toronto, Stoddart Books, 1998

SECCHI, Bernardo. A cidade do século vinte. São Paulo, Ed. Perspectiva, 2009 (2005)

SHANE, David G. Recombinant Urbanism: conceptual modeling in architecture, urban design and city theory. Chichester - England, John Wiley \& Sons Itd, 2005

SHARP, Thomas. Urbanismo. Buenos Aires, Lautaro/Pinguino, 1947.

SMEED, R. J.. El problema del tráfico en las ciudades. In: AAVV. Las incognitas del trafico urbano. Barcelona, Editorial Gustavo Gili S/A, 1968.

SMITHSON, Alison ed. Team 10: primer. Cambridge, Massachusetts, The MIT Press, 1968.

SOMEKH, Nádia; MALTA CAMPOS, Cândido. A cidade que não pode parar: planos urbanísticos de São Paulo no século XX. São Paulo, MackPesquisa, 2002.

SORT, Jordi Julià. Redes Metropolitanas. Barcelona: Gustavo Gili SA, 2006.

SOUTHWORTH, M.;BEN-JOSEPH, E. Streets and the Shaping of Towns and Cities. New York-NY: McGraw-Hill, 1997.

STARKIE, David. The motorway age: road and traffic policies in post-war Britain. Oxford, England, Pergamon Press, 1982.

STEIN, C. Towards New Towns for America. Cambridge, The MIT Press, 1967 (1957)

TAYLOR, G. Brooke. The mobilty society. Town and Country Planning Review. vol XXX, n¹1, nov1962, pp. 459-460

TAYLOR, Nigel. Urban Planning Theory since 1945. London, Sage Publications Ltd, 2008 (1999). 
TCPR - TOWN AND COUNTRY PLANNING REVIEW. Congested cities and country towns. Town and Country Planning Review, vol XXIV, n¹46, junho 1956, pp. 279-280.

TCPR - TOWN AND COUNTRY PLANNING REVIEW. Roads over houses. Town and Country Planning Review, vol XXV, n¹2, dezembro 1957, pp. 485-486.

TCPR - TOWN AND COUNTRY PLANNING REVIEW. The reshaping of British railways. Town and Country Planning Review, vol XXXI, n6, janeiro 1963, pp. 256-258.

TCPR - TOWN AND COUNTRY PLANNING REVIEW. Transport in New Towns: a change of enphasis. Town and Country Planning Review, vol XXXV, n8, agosto-setembro 1967, pp. 385-386.

TCPR - TOWN AND COUNTRY PLANNING REVIEW. Urban congestion and green belts: the Lord's debate. Town and Country Planning Review. vol XXIII. n². agosto 1955, pp. 359-363.

THOMAS, Whindhan. The Buchanan report. Town and Country Planning Review. vol XXXII. $\mathrm{n}^{\circ} 1$. janeiro 1964, pp 10-12

THOMSON, J. M. Great cities and their traffic. London, Penguin Books, 1977

TOLEDO, Benedito Lima de. Prestes Maia e as origens do urbanismo moderno em São Paulo, São Paulo, Empresa das Artes, 1996.

TRIPP H. Alker. Town Planning and Road Traffic. London, Edward Arnold, 1942 (1938).

VALDES, Antonio. Ingenieria de trafico. Madrid, Editorial Dossat S.A., 1971.

VASCONCELLOS, Eduardo Alcântara. Circular é preciso, viver não é preciso: a história do trânsito na cidade de São Paulo. São Paulo, Annablume/FAPESP, 1999.

VASCONCELLOS, Eduardo Alcântara. Transporte urbano nos países em desenvolvimento: reflexões e propostas. São Paulo, Annablume, 2000.

VASCONCELLOS, Eduardo Alcântara. Transporte urbano, espaço e equidade: análise de políticas públicas. São Paulo, NetPress, 1998.

VIDOTTO, M. Alison + Peter Smithson. Obras y proyetos. Barcelona, Editorial Gustavo Gili, 2005 (1997)

VILLACA, Flávio. Uma contribuição para a história do planejamento urbano no Brasil. In: DEÁK, C. \& SHCIFFER, S. R. O processo de urbanização no Brasil. São Paulo, FUPAM/EDUSP, 2004, pp. 169-244. 
WARD, Stephen V. Planning the twentieth-century city: the advanced capitalist world. Chichester, England, John Wiley \& Sons Ltd., 2002.

WATSON, Paton. Two view on high density. Town and Country Planning Review. volXXIII. $\mathrm{n}^{\circ} 132$, abril 1955, pp. 177-180.

WEINER, Edward. Urban transportation planning in the United States: an historical overview. Westport, Praeger Publishers, 1999.

WELLS, G.R. Comprehensive Transport Planning. London, Charles Griffin \& Company Ltd, 1975.

WHITE, P. Public Transport: its planning, management and operation. London, Taylor \& Francis Group, 2002 (1995)

WILHEIM, Jorge. O substantivo e o adjetivo. São Paulo, Ed. Perspectiva, 1976.

WILHEIM, Jorge. Projeto São Paulo: propostas para a melhoria da vida urbana. Rio de Janeiro: Ed. Paz e Terra, 1982.

WILHEIM, Jorge. São Paulo Metrópole 1965: subsídios para seu plano diretor. São Paulo: Difusão Europeia do Livro, 1965.

WILHEIM, Jorge. Urbanismo no Subdesenvolvimento. Rio de Janeiro: Editora Saga, 1969.

WILHEIN, Jorge. A obra pública de Jorge Wilhein. São Paulo, DBA Artes Gráficas, 2003.

\section{Planos Urbanos e de Transportes}

COLIN BUCHANAN \& PARTNERS. Bath: a planning and transport study.1965

COLIN BUCHANAN \& PARTNERS. Canterbury: traffic study. 1970a

COLIN BUCHANAN \& PARTNERS. Cardiff: Development and Transport Study (probe study report). 1966

COLIN BUCHANAN \& PARTNERS. Edinburgh: the recommended plan. 1972

COLIN BUCHANAN \& PARTNERS. Kuwait: national physical plan and master plan for urban areas, $1970 b$.

COLIN BUCHANAN \& PARTNERS. Portfólio do escritório, divulgado no início dos anos 1970. 
COLIN BUCHANAN \& PARTNERS. South Hampshire Study. 1966b.

FORSHAW, J. H.; ABERCROMBIE, P. County of London Plan. London, Macmillan and Co. Ltda., 1943.

MILTON KEYNES DEVELOP. CORPORATION. The Plan for Milton Keynes. UK, 1970. (volumes 1 e 2)

MILTON KEYNES DEVELOP. CORPORATION. The Plan for Milton Keynes: Technical Supplement No. 7 -Transportation. UK, sd. (Main consultants Llewelyn-Davies Weeks Forestier-Walker \& Bor)

RUNCORN DEVELOP. CORPORATION. Runcorn New Town - Master Plan. Nottingham, United Kingdom, Hawthornes of Nottingham Limited, 1967. (Arthur Ling and Associates)

SÃO PAULO (Cidade). Plano Urbanístico Básico - relatório técnico do consórcio Asplan; Daily; Montreal; Wilbur Smith. São Paulo, 1969. 
